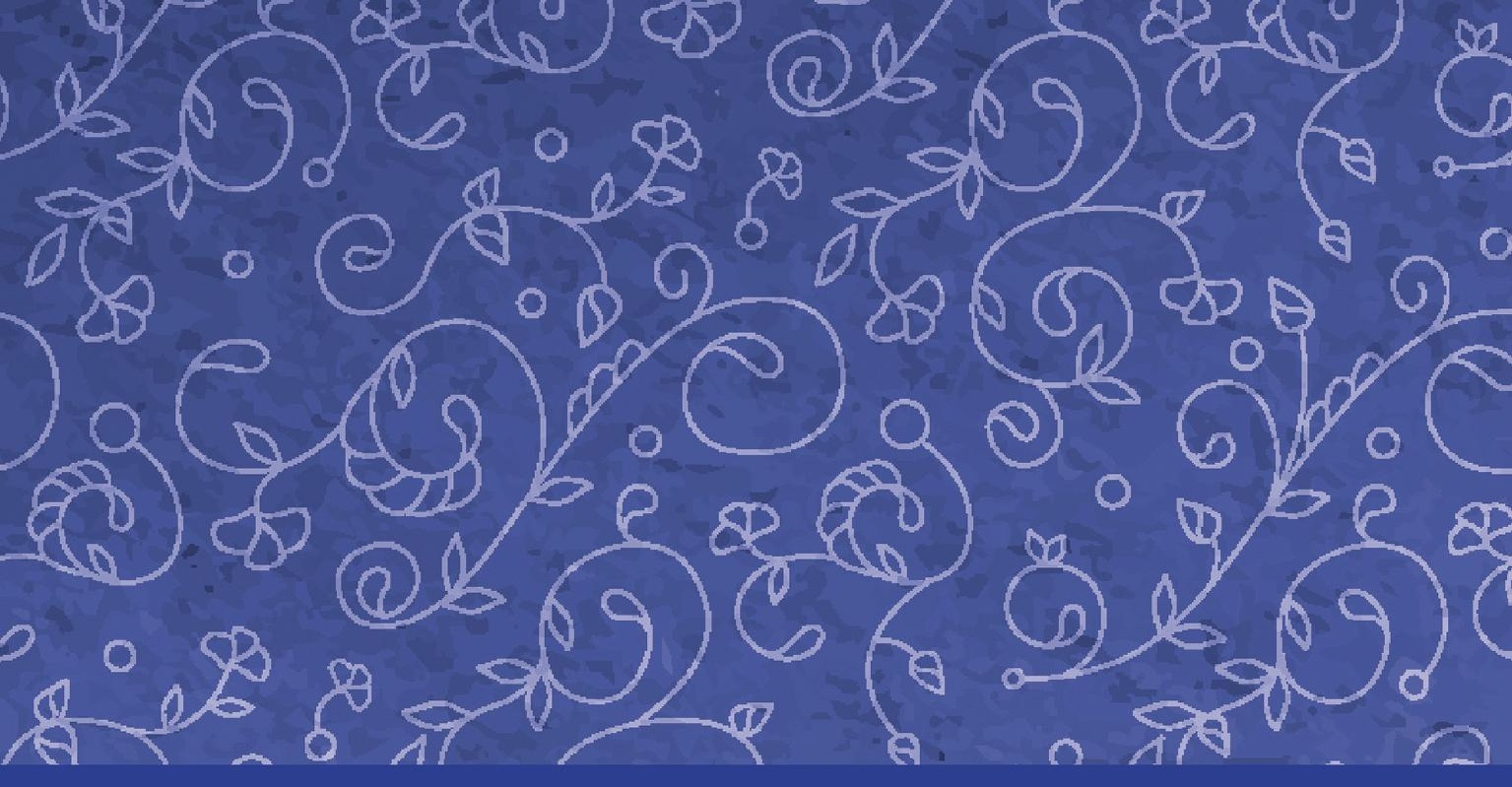
Routledge New Horizons in South Asian Studies

\title{
MODERNITY AND SPIRIT WORSHIP IN INDIA
}

\section{AN ANTHROPOLOGY OF THE UMWELT}

Miho Ishii

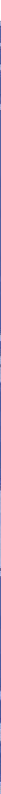




\section{Modernity and Spirit Worship in India}

This book investigates the entangled relations between people's daily worship practices and their umwelt in South India. Focusing on the practices of spirit ( $b \bar{u} t a)$ worship in the coastal area of Karnataka, it examines the relationship between people and deities.

Based on extensive fieldwork, this book links important anthropological theories on personhood, perspectives, transactions, and gift-exchanges together with the Gestaltkreis theory of Viktor von Weizsäcker. First, it examines the relations between büta worship and land tenure, matriliny, and hierarchy in the society. It then explores the reflexive relationship between modern law and current practices based on conventional law, before examining new developments in būta worship with the rise of mega-industries and environmental movements. Furthermore, this book sheds light on the struggles and endeavours of the people who create and recreate their relations with the realm of sacred wildness, as well as the formations and transformations of the umwelt in perpetual social-political transition.

Modernity and Spirit Worship in India will be of interest to academics in the field of anthropology, religious studies and the dynamics of religion, and South Asian Culture and Society.

Miho Ishii is an associate professor at Kyoto University, Japan. Her current research focus is on the relationship between spirit worship and environmental movements in South India. 


\section{Routledge New Horizons in South Asian Studies}

Series Editors: Crispin Bates, Edinburgh University; Akio Tanabe, Kyoto University; Minoru Mio, National Museum of Ethnology, Japan

Democratic Transformation and the Vernacular Public Arena in India

Edited by Taberez Ahmed Neyazi, Akio Tanabe and Shinya Ishizaka

Cities in South Asia

Edited by Crispin Bates and Minoru Mio

Human and International Security in India

Edited by Crispin Bates, Akio Tanabe \& Minoru Mio

Rethinking Social Exclusion in India

Castes, Communities and the State

Edited by Minoru Mio and Abhijit Dasgupta

Modernity and Spirit Worship in India

An Anthropology of the Umwelt

Miho Ishii

For a full list of titles please see https://www.routledge.com/Routledge-NewHorizons-in-South-Asian-Studies/book-series/RNHSAS 


\section{Modernity and Spirit Worship in India \\ An Anthropology of the Umwelt}

Miho Ishii 
First published 2020

by Routledge

2 Park Square, Milton Park, Abingdon, Oxon OX14 4RN

and by Routledge

52 Vanderbilt Avenue, New York, NY 10017

Routledge is an imprint of the Taylor \& Francis Group, an informa business

(C) 2020 Miho Ishii

The right of Miho Ishii to be identified as author of this work has been asserted by her in accordance with sections 77 and 78 of the Copyright, Designs and Patents Act 1988.

The Open Access version of this book, available at www.taylorfrancis.com, has been made available under a Creative Commons Attribution-ShareAlike 4.0 International license.

Trademark notice: Product or corporate names may be trademarks or registered trademarks, and are used only for identification and explanation without intent to infringe.

British Library Cataloguing-in-Publication Data

A catalogue record for this book is available from the British

Library

Library of Congress Cataloging-in-Publication Data

A catalog record has been requested for this book

ISBN: 978-0-367-41028-5 (hbk)

ISBN: 978-0-367-82266-8 (ebk)

Typeset in Times New Roman

by codeMantra 


\section{Contents}

List of illustrations vii

Preface

1 Introduction: towards an anthropology of the umwelt

PART ONE

Humans and the wild śakti of deities

2 The land of paddy fields, forests, and deities 35

3 The büta shrine and deities in Perar 48

4 Pạddana: the oral epics of deities $\quad 60$

5 Dances, oracles, and blessings in the ritual 70

6 The transaction of wild śakti 82

7 Playing with perspectives 94

\section{PART TWO}

Social transformations and the emergence of a new umwelt 107

$8 B \bar{u} t a$ 's agency in conflicts over the village shrine 109

9 Historical changes in land tenure in South Kanara 135

10 Modern law, customary law, and the reflexive imagination 164

11 Land reforms and deities as the 'owners of land' 183

12 Bütas in the midst of the development project 209 
vi Contents

13 The new umwelt in the industrial plant 236

14 Conclusion: being, pathos, and the umwelt 248

Glossary 263

Bibliography $\quad 275$

Index 291 


\section{Illustrations}

\section{Figure}

6.1 The transactional network between humans and būtas

\section{Tables}

2.1 The number of households based on religion in Mudu Perar and Padu Perar

2.2 The number of households based on caste group in Mudu Perar and Padu Perar

2.3 Land use in Perar

2.4 The crop calendar and yearly rituals in Perar 42

3.1 The prominent families in Perar in relation to būta worship 53

9.1 Land holding and land tax assessment of patțadār in Mudu Perar (Fasli 1312)

9.2 Caste/type of pațtadārs

9.3 Total number of registered patțadārs corresponding to assessed plots

9.4 Total number of registered pațtadārs belonging to Baṇța (by family)

10.1 Mundạabțtu guttu family property partition plan 177

11.1 Types of applicants and landlords 185

11.2 Types of Banța landlords 186

11.3 Types of land applied for rights in the Mundabetțu guttu $\quad 186$

11.4 Caste/group of households and population 187

11.5 Number of (a) landlord households, (b) tenant households, (c) domestic labourer households, and (d) other households by caste/group

11.6 Families of Banta landlord households 189

11.7 Area of land holdings of landlord households (2008) 190

11.8 Classification of holdings of landlord households according to manner of acquisition 

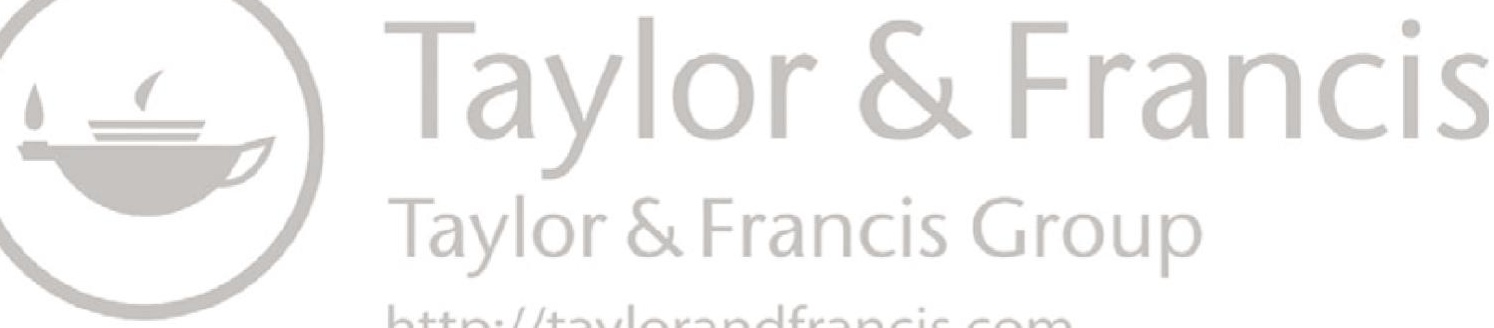

http://taylorandfrancis.com 


\section{Preface}

In a sense, this book follows an established line of anthropological predecessors focusing on the dynamism of religious practices and/in modernity. It is, after all, primarily a book about büta (or spirit) worship in South Kanara, a coastal area in Karnataka, India. Būtas are generally considered to be deities or spirits that dwell in forests and embody the realm of sacred wildness. In this book, I investigate the endeavours and struggles of people in village communities, who create and recreate their relations with the realm of sacred wildness through transactions with būtas, amidst social-political transitions such as colonisation, changes in land tenure systems, and development of mega-industries.

However, I also attempt to introduce a novel twist to this anthropological genre. The theoretical core of this book is the notion of the umwelt presented by Viktor von Weizsäcker, who uniquely developed Jakob von Uexküll's ideas on the existence of entangled and inseparable relations between an organism and its environment. By linking anthropological theories on personhood, perspective, transactions, and gift-exchanges to the theory of the umwelt, I attempt to consider the relations among villagers, land, nature, and butas as part of the dynamic and creative interactions between humans and their life-worlds, including nonhumans.

If this book successfully presents a perspective that exceeds, even a little, the limits of a monograph sticking to its discipline and geographical field, I owe it to the members of a research project titled 'Kansekai no Jinbungaku (The Studies of Umwelten)', undertaken at the Institute for Research in the Humanities, Kyoto University, since 2015. Discussions and conversations with colleagues from various academic backgrounds in the course of this project provided great inspiration in the writing of this book.

These discussions also inspired an earlier version of this volume published in Japanese under the title, 'Kansekai no Jinruigaku: Minami Indo ni okeru Yasei, Kindai, Shinreisaishi (An Anthropology of the Umwelt: Wildness, Modernity, and Spirit Worship in South India)', by Kyoto University Press in 2017. Though the core of the argument has remained consistent, through the long process of rewriting, this volume has become not a mere translation, but a fresh creation. I deeply thank Dr Masakazu Tanaka, my colleague 
and former supervisor, for his precious comments on the earlier version of this book.

Drs Crispin Bates, Akio Tanabe, and Minoru Mio, the series editors of Routledge New Horizons in South Asian Studies, gave me great support from the earliest to the final stages of publication of this book. Without their support and encouragement, it would not have been possible for me to complete this work. Nick Kasparek and Dr Yumiko Tokita-Tanabe made great efforts to improve the quality of this book. Their sensitive and deep knowledge of English greatly helped me construct the whole argument in English. I am also very grateful to the editors at Routledge, Dorothea Schaefter and Alexandra de Brauw, for their support in the publication of this volume.

After completing my doctoral and postdoctoral research on spirit worship in Ghana, I first visited South India in 2008, in search of a new field site. It was Dr Chinnappa Gowda at Mangaluru University who first introduced me to the fertile world of būta worship in South Kanara. Since the start of my fieldwork, Akshaya Shetty, her mother Baarati, and her father Harisha always provided me with warm and generous support. Vidya Dinker not only gave me wise advice, but also instilled the courage I needed to pursue difficult tasks in the field. Without their support and friendship, I could not have accomplished my research.

Finally, I would like to thank Kenta Funahashi and our two daughters, Hina and Sui. They accompanied me on my fieldtrips and shared my joy and wonder through the entire process. They provided me with great inspiration and encounters that would not have been possible if I were alone in the field. Therefore, I would like to dedicate this book, a fruit of our collaborative field life, to them.

Some of the chapters in this book are based on previously published papers. All have been extensively revised for the present volume. An early version of Chapter 6 was published as a paper entitled 'Wild sacredness and the poiesis of transactional networks: Relational divinity and spirit possession in the büta ritual of South India' in Asian Ethnology in 2015. Chapter 7 is based on a paper entitled 'Playing with perspectives: Spirit possession, mimesis, and permeability in the buuta ritual in South India' published in Journal of the Royal Anthropological Institute in 2013. Chapter 10 partly overlaps with a paper entitled 'Traces of reflexive imagination: Matriliny, modern law, and spirit worship in South India' published in Asian Anthropology in 2014. Chapter 12 is based on conference papers presented at the ninth and tenth International Convention of Asia Scholars (ICAS) in 2015 and 2017. Chapter 13 has evolved from the papers below: 'The chiasm of machines and spirits: Büta worship, megaindustry, and embodied environment in South India' published in 2014 in a volume entitled Ecologies of Care: Innovations through Technologies, Collectives and the Senses, edited by Gergely Mohácsi; 'The ecology of transaction: Dividual persons, spirits, and machinery in a special economic zone in South India' published in NatureCulture in 2015; and 'Caring for divine infrastructures: Nature and spirits in a special economic zone in India', which appeared in Ethnos in 2017. 
Preface xi

The research on which this volume is based was financially supported by Japan Society for the Promotion of Science (JSPS KAKENHI Grant Numbers 21720321, 24251017, and 26370949).

Miho Ishii

Kyoto

July 2019 

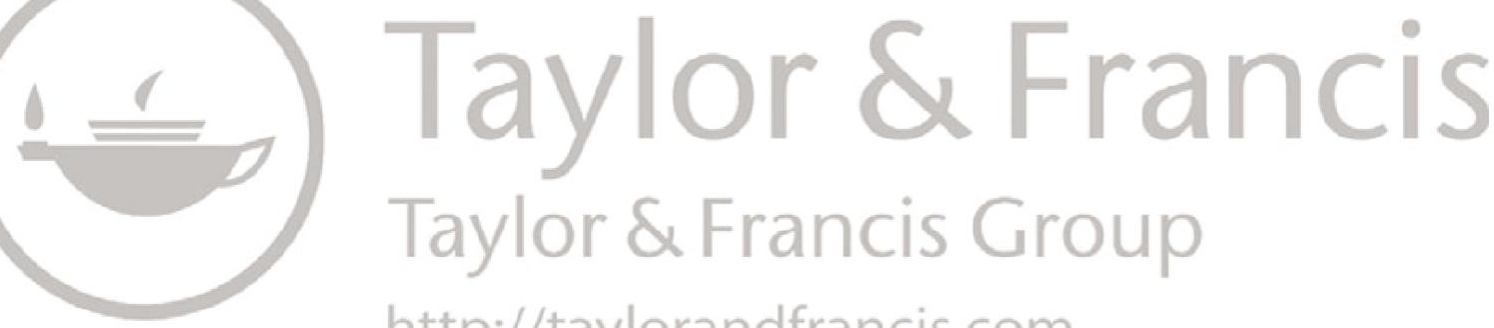

http://taylorandfrancis.com 


\section{Introduction}

\section{Towards an anthropology of the umwelt}

In the month of māyi during the hottest and driest season, büta rituals are held in many villages in South Kanara, a coastal area in Karnataka. ${ }^{1}$ Accompanied by drums and wind instruments played by Purușa musicians, spirit mediums of the Pambada or Nalike castes dance around the precincts of local shrines, issue oracles, and interact with people.

As apotheosised local heroes or heroines or as the spirits of wild animals dwelling in forests, būtas are generally regarded as deities. While būtas may travel across regions, they are generally believed to be closely linked to the land and nature of localities. Though normally invisible, their power, or sakti, ${ }^{2}$ fills the deep forests, hangs over the bush and ponds, and circulates through the woods, agricultural fields, and villages. Consequently, būtas are considered to originate from - and embody - a realm of sacred wildness.

Fieldwork for this monograph was mainly carried out in the two adjoining villages of Mudu Perar and Padu Perar in Mangaluru taluk, Dakshina Kannada district. ${ }^{3}$ Until administratively separated in 1904, these villages used to be a single entity called 'Perar', and are still collectively called 'Perar' by the villagers. ${ }^{4}$

In Perar, būta rituals are conducted in the geographical area that consists of houses surrounded by paddy fields, palm and areca nut farms, and deep forests and hills. As will be elaborated upon later, būta rituals are closely related to the ranks and duties of families, matriliny, and land tenure. In village society, būta worship is a sophisticated system that links people to land and nature. Embodying the realm of the wild, ${ }^{5}$ buttas mediate the relationships villagers have with fields and forests, and būta rituals facilitate the smooth succession of both lands and offices within families. Moreover, through the transaction of offerings and blessings (prasāda $)^{6}$ in rituals, the bütas authorise the hierarchies and relations among village families.

Direct encounters and interactions between people and deities is an essential element of būta worship. Villagers directly present offerings at altars and small shrines in their houses, and they receive oracles and blessings from possessed mediums at village shrines. While büta śakti is generally perceived as an invisible, fertile, and dangerous power that influences 


\section{Introduction}

the lives and destinies of villagers, through spirit possession it can also transiently manifest in dreadful, androgynous forms.

Drawing on the results of my observations of everyday practices in villages and considering villager relations with what they characterise as 'the wild', a realm actualised through interactions with bütas, this book explores how all these various relations create and recreate the social, religious, and ecological milieu, or in effect the umwelt, of village residents.

Before examining the notion of the umwelt in detail, it should be noted that rather than being static, the village communities studied in this book have been constantly adapting to changes since time immemorable. As described later, since the nineteenth century, rural society in South Kanara has been transformed through the development and penetration of modern legal and administrative systems. Since the mid-1990s, massive development projects in Mangaluru have also caused disruptive changes in rural areas, including the destruction of farmland and the eviction of villagers from the land they had farmed or otherwise had access to. Faced with these changes which can generally be called 'modernisation', people have tried to maintain or recreate their way of life by reorganising their relationships with others and by negotiating with strangers. Entangled as they are with various intentions and social relations, these endeavours are beset with conflict and difficulty. Moreover, for the villagers, relationships with bütas have always been central to their practices and decision-making. These relationships help them confront the challenge of incessant social change, both to keep what they have and to leverage the transitions as opportunities.

When we investigate the mutual formation and transformation of people's everyday practices and their umwelt in their reflexive interactions with modern laws and systems as well as in transactions with the realm the wild and deities, three mutually entangled subjects of study become clear: humans, the wild, and modernity. In the following section, I will examine previous studies that have focused on modernity and the occult, as well as on ontology.

\section{Theories of modernity and the occult}

Magical-religious phenomena such as witchcraft, magic, and spirit possession have long been important subjects in anthropology, and since the 1980s, many writers have considered how the occult in non-Western societies relates to modernity (e.g. Comaroff 1985; Geschiere 1997; Comaroff \& Comaroff 1999). ${ }^{7}$

In his early work, Taussig analysed Bolivian miners' worship of Tio, the spirit owner of the tin mines, as a cultural response of neophyte proletarians towards the capitalist mode of production. According to Taussig, peasants working in the mines understood wage labour and the new socio-economic system as evil and unnatural, and the devil figure of Tio strikingly articulated this interpretation. Devil worship thus represented both the predicament of the peasants and their critical consciousness and struggle against 
the exploitative modern capitalist economy (Taussig 1980, pp. 17-22, 144145, 232-233).

Geschiere, by posing the idea of 'the modernity of witchcraft', has also presented a fresh viewpoint for analysing the relationship between modernity and the occult. According to Geschiere, in postcolonial Cameroon and other African societies, discourses about witchcraft have burgeoned in modern sectors such as politics, sports, institutions of formal education, and so forth. Such rumours and discourses expose concern about the proliferation of novel forms of witchcraft, but they also reveal the popular interest in various hidden opportunities to acquire and accumulate new forms of wealth. In Africa, rumours and practices related to witchcraft are evidence of people's efforts to interpret changes brought by modernity and to gain control over them. Thus, Geschiere argues that we should focus on the "modernity' of witchcraft, rather than considering witchcraft in contraposition to modernity (Geschiere 1997, pp. 1-9; Ciekawy \& Geschiere 1998).

Likewise, using the concept of 'occult economies', Comaroff and Comaroff (1999) analysed the relation between the rise of occult phenomena and social economic conditions in postcolonial South Africa, where there has been a dramatic rise in fear and suspicion of occult phenomena such as witchcraft, Satanism, zombies, and ritual murder. According to the Comaroffs, these occult phenomena express the discontent and despair of people distressed by the mysterious mechanisms of the global market economy, but they are also symptoms of an occult economy waxing behind the civil surfaces of the 'new' South Africa. The practice of witchcraft and other mystical arts in postcolonial Africa was 'a mode of producing new forms of consciousness; of expressing discontent with modernity and dealing with its deformities' (Comaroff \& Comaroff 1999, p. 284, emphasis in original).

Focusing on modernity and the occult in non-Western societies, many observers argue along the same lines. When discussing transformations of traditional societies under the pressure of modernisation, people's occult practices are held to be significant in modern situations. They are often interpreted as distinctive responses to, or critiques of, changing social conditions.

Such an analytical frame may be embedded in the conventional methods and practices of anthropology, wherein anthropologists from Western societies have long felt impelled to study 'pre-modern' occult practices in non-Western societies and to publish the results to their own reading public. In this context, magical-religious phenomena such as witchcraft, magic, and spirit possession in non-Western societies have often been collectively regarded as a reference point not only to antithetically define 'the modern West', but also to disclose what ails the West through difference or metaphoric connection. Regarding this, Sanders wrote,

Anthropologists have thus foregrounded resistance and critique in many forms, from large-scale revolts and revolutions to their everyday and more spectral manifestations. Anthropological explanations here 
suggest that occult forces and discourses can be seen as offering a sustained critique of the genesis or intensification of capitalism, modernity, neoliberalism and globalization, specifically, of the novel inequalities and exploitations these things engender. Through the occult, the argument goes, Others in faraway places expose unsettling truths about our contemporary world and its woeful workings.

(Sanders 2008, p. 111)

Perhaps it was inevitable that anthropologists-tasked with studying the lives of non-Westerners and representing values and logics different from those in the West-would tend to analyse magical-religious practices in non-Western societies as critiques of or alternatives to a value system based on rationality, individualism, material possession, market economy, exchange value, and concepts understood to constitute modernity. Similar interpretations of the occult, however, predate anthropology and were already in evidence in mid-seventeenth-century Europe:

Discourses and legal actions naming and constraining "spirit possession" over the past four centuries helped to create the dual notions of the rational individual and the civil subject of modern states. The silhouette of the propertied citizen and free individual took form between the idea of the automaton - a machine-body without will - and the threat of the primitive or animal, bodies overwhelmed by instincts and passions.

(Johnson 2011, p. 396)

Johnson observed that according to the early modern philosophy of Europe, a person in the modern West who was overwhelmed by spirit possession was seen as the inverse of the rational, autonomous individual. This tendency to compare and contrast images of the self in Western and non-Western societies has persisted in recent studies of spirit possession and personhood. For instance, Smith (2006, pp. 19, 74-75) argues that spirit possession, as the exposure of the fluid and permeable nature of personal identity, coincides with features of South Asian personhood, which are fluid, divisible, and permeable. Here the possessed, or indeed the South Asian person, is construed in contrast with the ideal, autonomous, Western person.

More recently, however, interpretations of occult practices have gone beyond the simple inversion of idealised images of society and personhood in the modern West; rather, occult practices are now seen as exposing 'unsettling truths about our contemporary world and its woeful workings' (Sanders 2008, p. 111) or as critiques of modern Western values which presume the importance of individualism and material possessions (see Johnson 2011, p. 417).

Since the 1990s, when new notions such as the 'modernity of witchcraft' and 'occult economies' were introduced by some anthropologists, it has become common to interpret informant discourse on the occult as evidence of ambivalent attitudes towards modernity. For example, analysing occult 
narratives of the Mawri about roads in postcolonial Niger in terms of the materialisation of people's experience of modernity, Masquelier argues that roads are part of a complex economy of violence, power, and blood-objects of both fascination and terror. Thus, their tales linking roads with the occult should be understood as 'creative efforts to articulate local understandings of mobility, morality, and marketing in all their literal and metaphorical meanings', which brings to light people's troubled encounters with modernity (Masquelier 2002, pp. 829, 831-834). ${ }^{8}$

These recent studies have examined new dimensions and meanings of the occult in non-Western societies by considering it in relation to comprehensive modern phenomena, such as globalisation and neoliberalism. Even so, taking the occult in non-Western societies as a reference point that both enables a definition of what is modern and Western and provides an opportunity to critique problems with the West, most writers are still tied to the general viewpoint of previous studies. In other words, magical-religious practices in non-Western societies continue to be analysed in terms of their relation with, and response to, powers and social economic changes originating in the West. Such an analytical framework has led some anthropologists to refer to the occult too generally, without a deep analysis of the particular history, specificity, and locality of each phenomenon. ${ }^{9}$

Moreover, as is obvious in discussions of occult economies (Comaroff \& Comaroff 1999), studies of the occult in a non-Western context tend to assume that the modern values and systems that cause radical change in local society are beyond the understanding of local people, and consequently, occult practices are an imaginative expression of people metaphorically interpreting these changes. Framing magical-religious practices as imaginative interpretations or metaphorical critiques of modernity seems to obscure an understanding of how these practices are entangled with modern values and systems in concrete situations.

Before considering this aspect in more detail, in the next section I will examine a recent trend in anthropology which also focuses on magicalreligious phenomena in non-Western societies, but provides different ideas and methods for their analysis.

\section{Ontological questions and 'the reality of the other'}

Since the end of the 1990s, a host of new anthropological studies conducted through the lens of ontology have been published. Researchers have turned to ontology in order to criticise the anthropocentrism of modern social science and to complicate and invert the nature-culture dichotomy and its assumptions of the universality of nature and particularity of culture. To transcend these issues, multinaturalism, radical essentialism, the ontological selfdetermination of the other, and other alternative frames have been proposed. Leaving aside the varied anthropological studies approaching ontology through philosophy, phenomenology, and science and technology studies, ${ }^{10}$ 


\section{Introduction}

in this section I will mainly examine the arguments concerning what has been called the 'ontological turn' in anthropology (Henare, Holbraad \& Wastell 2007). It should be noted that the theoretical trend examined here, hereafter called the OT, does not cover all anthropological works that are 'ontologically attuned' (Kohn 2015, p. 323), that is say, that deal with ontological questions as an underlying theme; rather, this section is more narrowly concerned with recent discussions of the ontological turn. ${ }^{11}$

In addition to criticising the modern dichotomy of nature and culture, advocates of the OT also see it as means of freeing anthropology from the shackles of epistemology. Since the goal is 'taking things encountered in the field as they present themselves' (Henare, Holbraad \& Wastell 2007, p. 2), proponents of the OT take issue with focusing epistemologically merely on people's worldviews and with the reductionism entailed in describing fieldwork observations through modern rationality. Accordingly, following the OT, rather than elaborating on worldviews, anthropologists should engage with the ontology of the people in the field. Consequently, peoples who are assumed to have different ontologies, such as Euro-Americans and Amerindians, are understood as not just perceiving the same world in different ways, but as living in different worlds (Henare, Holbraad \& Wastell 2007, pp. 10-12; Holbraad 2009). In the OT, the concept of 'ontology' thus suggests a multiplicity of worlds and is inseparable from difference and alterity (see Gad, Jensen \& Winthereik 2015, p. 70). Here, these concepts do not refer to epistemological differences between worldviews, but are reserved for denoting ontological differences between lived worlds. A central tenet is radical alterity (Henare, Holbraad \& Wastell 2007, p. 8), which cannot be reduced to modern rationality. Proponents of the OT often use magicalreligious discourses and practices in the field as their main evidence of this radical alterity, focusing on myths, divination, animism, shamanism, and other things which have been looked upon as 'apparently irrational beliefs' (Sperber 1982). ${ }^{12}$

While the way the OT focuses on magical-religious practices in nonWestern societies may seem similar to conventional approaches in the anthropology of religion, there are some critical differences between them. As seen in discussions of rationality, ${ }^{13}$ most previous studies have tried in various ways to portray beliefs and practices in non-Western societies both as some variety of distinctive logic or function incompatible with modern rationality and as rationally apprehensible by Westerners despite their uniqueness. By contrast, proponents of the OT are critical of such attempts to transform the phenomena of a different ontological world into something else by interpretation and rationalisation.

The starting point of the OT - to take things in the field as they areis motivated by an advocacy of 'the ontological self-determination of the world's peoples' (Viveiros de Castro 2003, 2011a, 2014a). In other words, the OT does not attempt to interpret or represent its objects of study; rather, it wants to leave room for the people themselves. Specifically, Viveiros de 
Castro has stated that, since the ontological turn, anthropology is obliged to 'make room for the other', that is, to create the conditions for the ontological self-determination of the other. For him, the role of anthropology 'is not that of explaining the world of the other, but rather of multiplying our world', and as such, anthropologists should avoid 'explain[ing] too much' or 'try[ing] to actualise the possibilities immanent to others' thought', but instead, 'endeavour to sustain [these possibilities] as possible indefinitely' (Viveiros de Castro 2014a; see also Holbraad, Pedersen \& Viveiros de Castro 2014).

\section{Critiques of the OT}

The fresh, radical ideas of the OT have greatly influenced academia. This stimulation has also given rise to criticism. While most commentators appreciate the endeavour to reconsider the modernist view of humans and the nature-culture dichotomy, they question notions such as radical essentialism and ontological alterity, and also wonder about the methodology of taking things in the field as they are.

For instance, expanding on his argument supporting the motion tabled at a debate on anthropological theory that 'ontology is just another word for culture' (Venkatesan 2010), Candea pointed out that 'many accounts of ontology specify as their subjects human populations, broadly geographically conceived' (177), and that the outline of disparate ontologies tends to map onto what would previously have been called cultural groups. Thus, the idea of ontological alterity is not free from the 'difficult conundrums which dogged the anthropological study of cultural difference' (Venkatesan 2010, p. 179; see also Laidlaw 2012).

Vigh and Sausdal (2014) have also criticised the OT notion of 'radical alterity' owing to the methodological problems of translation and communication it brings, and because it diminishes the possibility of mutual understanding across ontologies. They also wonder how it could be possible to take things in the field as they are. By promoting the idea of accepting, without interpretation, what people tell us about their world, they say that the OT 'becomes an argument for pure indexicality with an almost oneto-one relationship between signifiés and signifiants' (Vigh \& Sausdal 2014, p. 61). Consequently, this kind of 'ontic' argument that 'things are what they are' can be fundamentally undermined 'by people's frequently expressed doubt and ambivalence about the nature of the real they inhabit' (Vigh \& Sausdal 2014, pp. 56-57, 61; see also Graeber 2015).

Gad, Jensen, and Winthereik (2015, pp. 73-75) have similarly pointed out that while proponents of the OT insist on the importance of 'things' to understand the ontological world of the other, they largely rely on discourses recorded during fieldwork or culled from other sources. The precept of 'taking things in the field as they are' may help researchers avoid conjectures and interpretations, but this approach also encourages researchers to take the discourses of their informants at face value and to regard their 


\section{Introduction}

accounts as indicators of a unique ontology (Graeber 2015, p. 20). ${ }^{14}$ It is also suggested that these problems are rooted in the premises of the OT, which assumes that people in a particular locality partake of a unique ontology and asserts the importance of ontological self-determination and the value of indefinitely sustaining the world of the other (see Venkatesan 2010, pp. 172-179; Graeber 2015).

\section{How can we understand the ontological reality of the other?}

As mentioned above, one of the critical points raised by arguments about the OT is how anthropologists should deal with the ontological reality of the other. This issue poses a long-standing fundamental question in a fresh way: what kinds of anthropological enquiry and description are possible when one is faced with realities that seem incompatible with modern rationality? To understand the directions that the OT might take anthropological theory regarding this question, it is necessary first to examine alterity and difference in more detail.

When proponents of the OT use 'radical alterity' and 'different ontology', alterity means alterity to modern rationality and difference refers to difference from modern Western ontology. This is evident when Viveiros de Castro writes that ontology came to the fore at a moment when 'the ontological foundations of our civilisation - and the unquestioned cultural supremacy of the peoples who founded it - are seen as starting to crumble' (Viveiros de Castro 2014a). In other words, at a time of crisis, the ontological gaze fell on those seen as generating realities other than those of the modern Western world. Similarly, Vigh and Sausdal (2014) point out that proponents of the OT define alterity and difference in relation to the notion of 'the Euro-American':

The notion of 'the Euro-American' appears to be essential for the ontological turn as it frames the ontographer's object of study by providing the background against which ontology and alterity can be defined.

(Vigh \& Sausdal 2014, p. 66, emphasis original)

As discussed in the previous section, in anthropological studies of religion, the occult in non-Western societies has often been analysed contrastively or metaphorically as a point of reference for defining 'the modern West'. At the same time, by interpreting the occult in non-Western societies in terms of modernity, these studies tend to reproduce an analytical framework that highlights the influence of power and systems from the West and presents the occult as an alternative to them.

In contrast, while the ontology of 'the other' in the OT, exemplified by occult practices in the field, is similarly demarcated by reference to, and defined through difference from, notions such as 'the Euro-American', it is never interpreted in relation to modernity or the Euro-American, but rather 
is conserved as it is. In other words, proponents of the OT try to avoid transforming the ontology they find in the field - the reality of the other-into something else, and thereby reducing it to modern rationality. Presenting the occult as a defining feature of local life, they also refrain from analysing the occult as a mere response to modernity.

In this light, Pedersen (2011) criticises the 'modernity of witchcraft' (Geschiere 1997), 'occult economies' (Comaroff \& Comaroff 1999), and other symbolic-functionalistic characterisations in previous studies, and attempts to describe shamanism in Mongolia in a different way:

Darhad shamanism, and particularly in its variations "without shamans," is not an occult economy "of" postsocialist transition; it "is" a distinct ontological condition in its own right.

(Pedersen 2011, p. 40)

Here, it is worth noting that proponents of the OT do not try to describe the ontology of the people in the field as a static cosmos separate from the outside world. Pedersen (2011), for instance, focuses on the relationship between shamanism and drastic social and political changes in northern Mongolia. Yet for Pedersen, Darhad shamanism is not something that only symbolises the local response or resistance to social change; rather, it is a fluid and multiple 'ontology of transition', just as post-socialist Mongolian society is (2011, pp. 35, 79).

Such arguments seem to succeed in proposing an alternative to the symbolic-functionalist views of previous studies. Even so, by representing shamanistic practices as the ontology of the other, a reality too fluid and indefinite to be captured by modern rationality, it repeats the conventional interpretations of the occult in non-Western societies as that which has escaped the influence of colonial and postcolonial states, and that which resists the categories of Western social science (e.g. Comaroff 1985, p. 263; Rosenthal 1998). ${ }^{15}$

To reiterate, while attending to social change, proponents of the OT attempt to describe the phenomena in the field as ontologically discrete, as things to be taken on their own terms without being reduced to responses to, or resistance against, modern social changes. This effort by proponents of the OT to take things in the field seriously, to restrain investigators from explaining phenomena using their own theoretical frames, and to make one's own world multiple by exploring the world of the other has been of great import in recent anthropology.

Proponents of the OT seem to take a position similar to that of the 'relativists' in the rationality debate (see Tambiah 1990), who asserted that notions in modern rationality could be revised and expanded by understanding the thought of non-Western peoples. ${ }^{16}$ The OT is more radical, however, in that proponents attempt to take alterity, which is regarded as incompatible with modern rationality, as it is without trying to render it into what is 
understandable for people in the West (Henare, Holbraad \& Wastell 2007, pp. 11-12; cf. Viveiros de Castro 2004a).

Meanwhile, the endeavours in the OT to emphasise the importance of the 'ontological self-determination of the world's peoples' and strive for a 'permanent decolonization of thought' (Viveiros de Castro 2011a; Holbraad, Pedersen \& Viveiros de Castro 2014), along with criticisms of excessive interference in the ontological world of the other, seem to indicate a sort of strategic essentialism (Gad, Jensen \& Winthereik 2015, p. 78; see also Venkatesan 2010, pp. 172-179; Candea 2011). Few would deny the ethical merits of this stance, especially when we reflect on how anthropological research represents the lives of local people in places where pervasive power, values, and systems serve to strengthen the hegemony of the West. The appeal of this ethical impulse is all the more reason to carefully examine the issues arising in the attempt to find radical alterity in the magical-religious practices of the people that anthropologists study and to describe them as indicators of a radically different ontology. In the next section, focusing on the notion of existence, or being, I will consider in more detail relations between modernity and magical-religious phenomena.

\section{Rethinking beinglexistence}

As suggested in the previous section, proponents of the OT have often focused on magical-religious practices in their fieldwork, and then characterised them as ontologically unique and incompatible with Western ontology. Critics have pointed out that this approach may lead to an emphasis on those parts of discourse and practice that suggest alterity, a simplification of people's realities due to an insufficient grasp of complicated relationships involving various differences and divisions in their lives, and a blindness to ambiguities in the realities in life as it is lived (Venkatesan 2010, pp. 172-179; Candea 2011; Vigh \& Sausdal 2014; Graeber 2015).

Furthermore, by presuming that the people under study live in a radically different ontological world, the OT severely limits analysis of how people engage with 'modern' systems and orders. The previous section of this chapter cited recent anthropological studies of religion in which the occult was characterised as a means of imaginative interpretation of modern situations beyond the common knowledge of its practitioners (e.g. Comaroff \& Comaroff 1999; Masquelier 2002). Taking issue with this, proponents of the OT consider the occult as evidence of worlds based on unique, radically different ontologies. In privileging alterity, however, proponents of the OT pay insufficient attention not only to how people engage with systems, logics, and ways of life that embody ideas and values predominant in the West, but especially to how magical-religious practices and 'modern rationality' are entangled with each other. ${ }^{17}$

Rather than essentially unknowable, ontologically different worlds, what most anthropologists encounter during their fieldwork today seem more 
likely to be situations in which familiar modern Western logics, values, styles, and systems have permeated and now significantly constitute people's everyday lives. This is not to say that a coherent 'modern rationality' unilaterally blankets their lives or that in their engagement with change, everyone or anyone completely 'gets with the program'. Rather, local people adapt to changing circumstances with logics, values, and ideas that mesh with modern rationality and that have the power to create and recreate the realities of people. We see evidence of this in objects, concrete systems, plans, vocabularies, styles, and social relations. Meanwhile, logics, values, and ideas that differ from modern rationality are also locally embodied in objects, concrete systems, vocabularies, social relations, and behaviours, and these continue to have a role in creating and recreating local reality.

In such circumstances, people may hold and situationally switch between multiple logics, values, and modes of being, and also coordinate and reconstitute relations with others to maintain and recreate their lives. Magicalreligious practices and narratives, which have been regarded in the OT as at the core of different ontologies, are not outside the processes of reconstitution and transformation; rather, they are key focal points of these processes.

And if people do create and recreate their lives in processes that are entangled in various logics, values, and modes of being that together comprise the lived 'reality' of people, anthropologists should then carefully observe and ethnographically describe those processes. Important elements such as these evade ontography, the attempt to record worlds that are based solely on radically different ontological premises. At the same time, no careful ethnographer would simply assume that logics, values, and modes of being familiar in the modern West are totally harmonious or commensurable with those encountered during fieldwork. The aim of ethnography is instead to present processes in which multiple logics, values, and modes of being - each with its own different history and impetus - are embodied and expressed in different systems and social relations, and to describe how they encounter each other, conflict, and interrelate, while they nonetheless continue to diverge from each other and retain discrepancies. The ethnographer also aims to describe the diverse actions and relationships of the people who are involved in various conflicts and entanglements, and to understand the thoughts and emotions arising from these actions, relationships, conflicts, and entanglements.

From this perspective, the lives of the local people studied by anthropologists can be seen as involving both constraints and contingency, as they constantly shift between several modes of being with different logics, values, and histories. This perspective urges us to analyse the processes that form and transform the lives of local people in their encounters and interactions with various others. The ends of this analysis thus differ from those of the OT, which assumes that the people in the field always confront indefinite contingency, or live in a unique ontological world that enables them to form and transform themselves through a unique relationship with others (e.g. Viveiros de Castro 2004b). 


\section{Introduction}

Furthermore, to deeply comprehend the relational and variable dimensions of people's lives - another goal mentioned by proponents of the OT, that is, the relation to the other and alterity from oneself (Viveiros de Castro 2011b; Holbraad, Pedersen \& Viveiros de Castro 2014) — it is necessary to reconsider the central notion of being, or existence, which has moved into the limelight through an accumulation and circulation of arguments in the OT. In the following section, I will therefore consider this concept from a different angle.

\section{The constraints and contingency of life: rethinking beinglexistence}

Intending to take seriously the things they find in the field, proponents of the OT set out to describe - as they are, without reductive interpretation - the ontological worlds in which magical-religious phenomena such as spirits, deities, and witchcraft can exist. Then, through the repetition and circulation of arguments arising from this intent, they performatively centralise the notion of being, or existence, in their ontographic anthropology. The relationship between reality and virtuality in the OT illustrates this point.

Henare, Holbraad, and Wastell (2007) have declared that one of the significant methodological propositions of the OT is to 'take things in the field as they are'. Here, things are not merely tangible objects, but also concepts. For instance, when a Cuban diviner says that the powder used in a séance is power, rather than interpret the statement as a peculiar cultural belief, it is important to view the powder as actual power. When adopting this radical constructivist approach, no ontological distinction is made between discourse and reality or concepts and things:

We argue that in order for difference to be taken seriously (as 'alterity'), the assumption that concepts are ontologically distinct from the things to which they are ordinarily said to 'refer' must be discarded. From this it follows that alterity can quite properly be thought of as a property of things - things, that is, which are concepts as much as they appear to us as 'material' or 'physical' entities.

(Henare, Holbraad \& Wastell 2007, p. 13, emphasis in original)

In the OT, the world in which powder is power is not a new fantastical region of 'our own' world (Henare, Holbraad \& Wastell 2007, p. 12); it is simply a different world. Moreover, proponents argue that to form a conception of a different powder (or a different world) is to actually conceive it, to think it into being. When the distinction between things and concepts collapses, 'thought here just is being', and 'conception is a mode of disclosure that creates its own objects' (Henare, Holbraad \& Wastell 2007, pp. 14-15). Therefore, when we conceive of a different powder, we create thing-concepts such as 'powerful powder', as does the Cuban diviner who creates new objects by enunciating new concepts (Henare, Holbraad \& Wastell 2007, pp. 3-6, 12-15; see also Holbraad 2007, 2012, pp. 157-161; Holbraad \& Pedersen 2017). 
Such assertions in the OT clearly challenge previous rationalistic approaches to 'apparently irrational belief' taken as simply unrealistic fantasy. By reiterating such assertions, however, proponents of the OT seek to take each thing and each notion encountered in the field into the sphere of being. While remaining virtual and indefinite for 'us', these things are considered to be extant forces or entities to the extent that they are considered by the ontographer to really exist for the people (see Viveiros de Castro 2011a, 2013, 2014a).

On this point, through comparison with the traditional use of the term ontology, Graeber (2015) has drawn attention to the distinctive use of the notion in the OT. He explains that, in ancient Greek, the word meant 'a discourse (logos) about the nature of being', and that this has remained the core meaning; for ontographers, however, it is used as a synonym for 'way of being' or 'manner of being' (Graeber 2015, p. 15). Similarly, Vigh and Sausdal have pointed out that the meanings of ontic and ontological are conflated in the arguments of the OT; even while emphasising the notion of virtuality based on Deleuze, proponents of the OT are mostly indifferent to the perils of essentialising objects by defining what 'is' (Vigh \& Sausdal 2014, pp. 51, 63).

As discussed earlier, proponents of the OT assert that anthropologists should, indefinitely and as far as possible, maintain the ontological world of the other as the potential for how things could be otherwise (Viveiros de Castro 2011a, 2014a; Holbraad, Pedersen \& Viveiros de Castro 2014). As Vigh and Sausdal (2014) observe, this intention seems to conflict with taking things in the field as they are and describing them in the ontic state of what $i s$, as opposed to what might be.

In the OT, however, these two intentions do not necessarily pull in different directions. By way of illustration, in Viveiros de Castro's discussion of Amerindian perspectivism, he observes that the statement 'animals are people' often occurs in Amazonian ethnographies. In the world of the indigenous people described in these ethnographies, a jaguar might regard itself as a human and see humans as animals (i.e. as prey). At the same time, an ordinary human regards itself as a human, and sees animals as animals (Viveiros de Castro 1998, 2014b, pp. 56-57). From the ordinary human perspective, the world seen by a jaguar is potentially an alternative world, a world in which a human cannot directly live.

In Viveiros de Castro's work, corresponding to the relationship between humans and animals in Amerindian ontology, the relationship between 'we' in the modern West and 'they' as the other for the Western self is presented in terms of ontological differences with each other: 'their' ontological world signifies a possible world which is different from 'our' world, one that should not be actualised by 'us', but should be realised as virtual:

To maintain the values of the other as implicit does not mean celebrating some numinous mystery that they enclose. It means refraining from actualizing the possible expressions of alien thought and deciding to 
sustain them as possibilities ... The anthropological experience depends on the formal interiorization of the "artificial and special conditions" to which Deleuze refers. The moment at which the world of the other does not exist outside its expression is transformed into an "eternal" condition - that is, a condition internal to the anthropological relation, which realizes this possibility as virtual.

(Viveiros de Castro 2011a, p. 137, emphasis in original; see also Viveiros de Castro 2014b, p. 196)

The meaning here may be clearer if we consider Deleuzian distinctions between reality, possibility, actuality, and virtuality:

The only danger in all this is that the virtual could be confused with the possible. The possible is opposed to the real; the process undergone by the possible is therefore a 'realisation'. By contrast, the virtual is not opposed to the real; it possesses a full reality by itself. The process it undergoes is that of actualisation.

(Deleuze 1994, p. 211)

According to Kimura (1997), in the philosophy of Bergson and Deleuze, object, or the objective, denotes that which has no virtuality, and thus it is considered either as possible or as real. On the other hand, the subjective is virtual, that is, in the process of being actualised; at the same time, it possesses a reality of its own (Kimura 1997, pp. 95-96; see also Deleuze 1991, pp. 41-43, 96-97). ${ }^{18}$

With these things in mind, Viveiros de Castro's statement could be paraphrased: the world of the other signifies a 'possible world', precisely because it seems to have no existence beyond its expression. We should maintain it as indeterminate and virtual, and at the same time, we should deal with it as real, without trying to explicate or actualise it.

When such a claim is made with the ideals of the 'ontological selfdetermination of the other' (Viveiros de Castro 2014a) and the radical essentialism of taking thing-concepts in the field as they are, there is an unexpected effect: a phenomenon which has no existence outside of being expressed by people - what is subjective, or virtual for us - is realised as objective for them. This effect emerges when the notion of the Deleuzian Other is projected upon the people in the field. For instance, Viveiros de Castro writes,

The Other thus appears as a condition of the field of perception: the existential possibility of those parts of the world that lie beyond actual perception is guaranteed by the virtual presence of an Other that perceives them: what is invisible to me subsists as real by being visible to an other.

(Viveiros de Castro 2013, p. 478, emphasis added) 
It is noteworthy that, according to the terminology of Bergson/Deleuze on which these assertions are based, the object/objective does not have virtuality (Deleuze 1991, p. 41). Here, the realm of the virtual for the people under study, which is suggested by the mention of such things as a jaguar's perspective that cannot be perceived by ordinary humans or virtual personhood in animals (Viveiros de Castro 2014b, pp. 57-58; see also Holbraad 2007,2012 , pp. 163-172), is subsumed to the objective reality of the people. Moreover, it is subsumed to the realm of the ontic beinglexistence as an index of the radical alterity of the ontological world of the other ${ }^{19}$

The centrality of being/existence in the OT, however, must be reconsidered when we turn to the contingency, inscrutability, and limitation of the state of being. It leads us to rethink the relationship between humans and the realm of the virtual that has yet to appear, or has already disappeared, as something.

This does not mean that things such as spirits, witchcraft, and jaguarhumans simply exist in one ontological world, but remain virtual in another. Rather, it points to the fundamental contingency, transience, inscrutability, and uncontrollability of the state of being in a particular time and space, not only for 'us', but also for the people in the field. In a sense, ontological self-determination is a promise that can never be fulfilled for anyone.

If we take seriously the fundamental contingency, incomprehensibility, and fragility of being, then to understand the magical-religious practices of the people we study, it is necessary to find a new analytical dimension that differs from the one that examines relations of various beings on the presumption that they all exist. One such dimension is that which does not exist in the same sphere as ontic being, and yet enables things to appear contingently in a unique way and to interact with each other. To introduce new dimensions that allow consideration of a 'reality' in which various beings relate and interact with each other, it is necessary to create a new theoretical frame.

To investigate the mutual interactions and transformations of entities and forces beyond the sphere of ontic beings, in the next section I will examine the ideas proposed by Viktor von Weizsäcker, who developed the concept of umwelt, which enables us to explore the lives of humans and other organisms in processes of mutual formation within milieus, and moreover, to consider their formations and transformations in phase and timescale beyond the ontic being/existence.

\section{Exploring umwelt studies}

As originally proposed by von Uexküll, umwelt is a means of examining the uniqueness of the world lived by each creature, which is inseparable from its way of being, including its perceptions, bodily form, and patterns of behaviour. This insight, that is, that each creature exists in a unique world totally appropriate to its form of life, contrasted with the Darwinist presumption 
that each creature was, more or less, adapted to the world as a totality, including all creatures (von Uexküll 1921). Putting the organism at the centre enabled the conceptualisation of plural worlds (Welten) and the relativisation of the anthropocentrism of Darwinist accounts. Next, I will examine the work of von Weizsäcker, especially the Gestaltkreis theory he elaborated, to explain the relations between an organism and its umwelt.

\section{Gestaltkreis theory}

While von Weizsäcker incorporated von Uexküll's basic conception of umwelt, unlike von Uexküll, who tended to characterise the relation between an organism and its umwelt as harmonious and self-sufficient, von Weizsäcker focused on instability and crisis, that is, the dynamic relations between an organism and its umwelt. Viewing the organism as a subject that creates and recreates itself in relation to the umwelt, he paid particular attention to interactions and coherence in encounters between organism and umwelt. ${ }^{20}$ Below, based on his main work entitled 'Der Gestaltkreis: Theorie der Einheit von Wahrnehmen und Bewegen [The Gestaltkreis: Theory of the unity of perception and movement]' (1997[1950]), I will present a broad outline of his theory. ${ }^{21}$

Literally translated, the term Gestaltkreis means 'circle of form'. According to von Weizsäcker, it refers to the emergence of a movement-form of an organism through mutual, circulative interaction with its umwelt:

The emergence of the form [of an organism] must be a closed circle insofar as there is no given order of first and next in its coming together ... Thus, we will call the emergence of the movement-forms of organisms Gestaltkreis.

(von Weizsäcker 1997, p. 254, emphasis in original)

Thus, in Gestaltkreis, perception, body-form, patterns of movement, and other things that constitute the mode of being of an organism are created through encounters and interactions with the umwelt. Meanwhile, as an organism encounters its umwelt, an order coherent to the mode of being emerges between the organism and the umwelt. I shall refer to these general concepts of von Weizsäcker (1997), such as the circulative interactions of an organism and its umwelt and their coherent relations and co-existence, as Gestaltkreis theory.

\section{'Subject' and crisis}

In Gestaltkreis theory, an organism's life-form, or mode of being, is regarded as undergoing incessant creation and recreation through encounters and interactions with its umwelt (von Weizsäcker 1997, pp. 235-236, 304-305). While an organism is predisposed to maintain a stable life-form, it can undergo 
transformations in response to encounters with its surroundings. At the same time, these encounters and interactions also transform the emerging order between the organism and the umwelt. Gestaltkreis theory thus offers insight into how a coherent relationship between an organism and its umwelt is created performatively through their interactions and, at the same time, how the life-form of an organism may be easily transformed through accidental encounters and fluctuations in coherence.

In the course of its lifetime, an organism may experience tension between ongoing stability and the need for self-transformation in relation to its umwelt. Namely, when a coherent relationship between an organism and its umwelt endures, it is experienced by the organism as the stable condition of itself. The balance, however, is easily upset by new encounters and changes to the organism and to its surroundings. In such a situation, the organism strives to preserve the coherent relation with its umwelt by partly transforming its mode of being. ${ }^{22}$

If we focus on an individual organism, this process could be interpreted as a sublation (Aufheben) of its life-form. If we expand our view to encompass the continuity of life beyond individual organisms, the entire process would then be considered the continuation of life itself through life-form renewal by each organism. von Weizsäcker considered life, which succeeds through the repetition of organisms' birth and death, as a recurring cycle. He referred to this continuity as the circle of life (Lebenskreis) (von Weizsäcker 1997, p. 321).

von Weizsäcker developed his thought on this issue through two concepts: subject and crisis. In this frame, rather than connoting psychological functions or states, subject refers to the unity of an organism, which persists or is endangered in relation to its umwelt (1997, pp. 300-301). For an organism that has maintained a unique relation with its umwelt, a crisis is a critical event in which identity and continuity are no longer viable. In a crisis, when the coherent relation with the umwelt is broken, an organism is brought to a critical juncture: either it transforms its life-form and survives or it does not meet the challenge of vicissitude and disappears (von Weizsäcker 1997, p. 298). von Weizsäcker did not assume, however, that something like a united subject existed autonomously and stably before the crisis. Rather, the lifeform of an organism as a subject is constituted and reconstituted through incessant encounters with vicissitudes and crises.

We recognise the subject correctly when it is threatened with its disappearance in a crisis ... The subject is not a fixed possession; rather one must be constantly procuring it in order to possess it. The unity of the subject forms the counterpart to the unity of the object. Just as the unity of various objects and events in our umwelt can be constituted in perception and action only through a functional change, so too is the unity of the subject constituted in the recovery repeated incessantly throughout the discontinuities and crises.

(von Weizsäcker 1997, pp. 300-301) 
This insight sheds light on the contingency and discontinuity of the lifeform of an organism as a subject, which temporarily appears in its relation to the umwelt. Here, the paired concepts of Pathisches and Ontisches also come into play.

\section{Pathisches and Ontisches}

For von Weizsäcker, the crisis that an organism undergoes in relation to its umwelt shows Pathisches of life. Pathisches, which can be glossed as pathos, is discussed in more detail below.

While each organism behaves actively in relation to its umwelt, it is also passive in the sense that whether it receives life or suffers the burden of life, it just happens to exist (1997, pp. 312-313). In particular, fluctuations in and ruptures of coherence with the umwelt caused by out-of-the-ordinary changes force an organism, at the risk of its life, to transform its life-form. von Weizsäcker characterised this state as Pathisches, which contrasts with and sublates the state of Ontisches, or the ontic (1997, p. 314). Here, Pathisches refers to the visceral drives that enable an organism to relate to its umwelt. It also denotes the passive state of being of an organism that not only lives its life actively, but also is lived by impersonal life itself in its body (see Kimura 2010, pp. 555-556).

According to von Weizsäcker, the fundamental basis of organisms' existence can never be grasped through biological experience. Kimura explained this basic relationship (Grundverhältnis) (von Weizsäcker 1997, p. 336) as the relationship between each organism and life itself. Namely, an organism is individualised as a limited being by its body, while its life dissolves into the fathomless depth of life itself (Kimura 2005, pp. 8-9).

Ontisches is thus a state of being as an organism comes to be individualised, an unstable and transitory form of life based on its unique relationship with its umwelt. Meanwhile, Pathisches denotes the passive and visceral relations of Ontisches, or a life-form which fleetingly appears, with life itself forming the basis for the emergence, transformation, and disappearance of an organism (see von Weizsäcker 1997, p. 337).

In Anonyma, von Weizsäcker (1946, pp. 10-12) posits Pathisches as a basic attribute of organisms: animate beings are pathisch (the adjectival form of Pathisches) and inanimate beings are ontisch (the adjectival form of Ontisches). In this schema, ontisch merely denotes pure being or bare existence (das nackte Sein), or in other words, that someone or something just is (see Nausner 2008, p. 196). Meanwhile, pathisch connotes existence that is received (erlitten) rather than assumed. For von Weizsäcker, Pathisches also has personal or subject-bound attributes.

Although von Weizsäcker conceived of only organisms as pathisch, this concept can be developed in new directions when we consider animism, a frame that allows for the life of inanimate beings and for the personhood of nonhuman beings. Things that are invested with life or personhood, even 
while they remain inanimate or nonhuman beings, can be characterised as pathisch rather than ontisch in that their existence is received rather than assumed. In other words, these beings are thought to appear and to stay (iru, in Japanese) transiently in particular time and space, rather than just to exist $(a r u)^{23}$ in the ontic state of things.

While thinking through the OT seems to bring everything observed in the field into the sphere of ontic being/existence, von Weizsäcker's concepts enable a better-defined characterisation of being; as a pathisch form of life, being can emerge transiently like a light flickering momentarily from the sea of life itself.

\section{The temporality of being and its potential for transformation}

Although each organism is contingent and transformable, each is nonetheless influenced and limited by the orders that have formed naturally in relation to its umwelt. The life-form of any organism is thus formed through temporality, which includes the accumulation of the organism's encounters and interactions with its umwelt. At the same time, the pathisch attribute of an organism leads to the potential for its form of being, which arose in a particular emergent order, to be dynamically sublated into something else.

In effect, any encounter of an organism with its umwelt may lead to transformation, and yet, the encounter is oriented by the life-form as it has already been lived by the organism. While an organism's perceptions and movements enable the emergence of an umwelt coherent with itself, its lifeform has been prescribed by the order in which life beyond the individual organism has continued. Regarding the temporality of the life-form of an organism, von Weizsäcker wrote,

We should establish the process of the movements [of an organism] ... as a proleptic one. How this happens will be fundamentally defined through its relationship to time. Namely, what happens now must be described as what is coming from a past that has already happened and thus cannot be changed, and is also going into a future that has not yet happened ... and thus has not yet been determined.

(von Weizsäcker 1997, p. 264, emphasis in original)

This describes the fundamental thrownness (Geworfenheit) of an organism as a united subject that was originally thrown into the continuity of life and therefore oriented by the order of the umwelt, which was coherent with its life-form. ${ }^{24}$ At the same time, it allows that each subject, living within its coherent order of life and umwelt, can transform and renew both its life-form and the umwelt through new encounters and interactions.

Even though the basic model for this theory was derived from the relations between the organism and its umwelt, Gestaltkreis theory can also 
help elucidate how a person encounters others (see von Weizsäcker 1997, p. 273). Here, issues arising in the encounters and interactions between an organism and its umwelt can be reformulated both as issues arising in the encounters and relations of individual persons with other persons and as relations between historical social orders and the life-forms of people.

Although von Weizsäcker only suggested the possibility of investigating the social dimensions of Gestaltkreis (1997, pp. 316-317), ${ }^{25}$ I find the application of his concepts in this way useful because they provide important ideas for grounding the inquiry of how a person encounters others. In the next section, by examining encounters and interactions between people and deities in South Kanara, I will attempt to suggest the usefulness of Gestaltkreis theory for anthropology.

\section{Inquiring into how a person encounters other beings}

As mentioned at the beginning of this chapter, this is an investigation into the relationships among humans, deities, and the realm of the wild, which are embodied both in buta worship and in the mundane social relations and practices of the people in rural South Kanara. Focusing on concrete events, I will examine these entangled relations, their historicity, and their transformations, starting with the fundamental question of how a person creates and recreates a world and his/her life-form through encounters and interactions with others, including nonhuman beings.

Ideas and concepts presented in Gestaltkreis theory - the mutual formation and transformations of an organism and its umwelt, Pathisches contrasted with Ontisches, and the unknowable life itself forming the basis an organism's life - are useful tools for considering this question. Referring to these ideas, I will illustrate the relationships among people, deities, and the realm of the wild in South Kanara.

For people living in rural South Kanara, the dense forests and hills that provide ample headsprings and are filled with the signs and sounds of various creatures are both the source of life and the realm of the unknown. The sakti (divine power) of deities exemplifies this multifarious quality, as overflowing from the depths of the forest and flowing into the realm of humans, this śakti is thought to bring fertility into agricultural fields and thus enable people to sustain their life, while simultaneously endangering them either through its excess or through its exhaustion.

The relationship between people and the realm of the wild corresponds to the relationship of an organism with its umwelt, and to the pathisch relationship of a subject with life itself. In a sense, in their relationship to the realm of the wild through büta worship, people are passive and contingent beings who entrust their forms of life to their relations with the wild and deities. At the same time, through intimate relations with land and nature in their daily life, and by interacting with deities in rituals, they form affective relationships with the realm of the wild and act towards it. 


\section{The realm of jōga and māya}

In Tuḷ, the native language in South Kanara, the realm of 'reality' inhabited by humans and other beings is called $j \bar{o} g a$, while the realm of the unknown filled with sakti is called māya. ${ }^{26}$ If we consider these two realms in reference to the pathisch relationship of people with the realm of the wild, they can be seen as follows: the realm of jogga is regarded as the phase of the tangible or actual, where humans and nonhuman beings appear, encounter each other, and interact; whereas the realm of māya filled with sakti is regarded as the phase of the virtual, where the individuality of each being merges into impersonal life itself in the depths of the wild. Beyond human control or consciousness, śakti as wild divinity in the realm of māya flows into the realm of jogga, manifesting itself, for example, in spirit possession and through oracles. The time and space in which śakti appears before people can be considered as a fluid threshold between the tangible and intangible, or the actual and virtual. ${ }^{27}$ Through temporary appearances of śakti in the form of bütas, people are able to interact with the realm of māya.

\section{The umwelt for the people: exploring the fringe}

As I hope to show in this book, social relations in rural South Kanara have been formed and oriented based on the pathisch relationship of the people with the realm of the wild, which is embodied in encounters and interactions with bütas. This is evident in the way that most of the customary laws and the social organisation in the village society - including ranks, ritual duties, land holding by manors, the matrilineal succession of the houses, and the rituals themselves - are based on the worship of butas that embody the sacred wildness. At the same time, the laws and social organisation have evolved to support the pathisch relationship of the people with the realm of the wild.

The transaction of offerings and blessings between people and deities shapes customary laws and social relations. Linking the village, paddy fields, būta shrines, and forests and hills, gift-exchange between deities and people who belong to various castes and houses embodies the circulation of sakti from the realm of the wild to that of humans, and vice versa.

For these people, who live in villages surrounded by vast agricultural fields ensconced in deep forest, their experiential umwelt is a realm of various beings whom they encounter and interact with in their daily lives. They create and recreate their forms of life through encounters and interactions with various others. These others are both human and nonhuman, extending from creatures in the forest to bütas, who temporarily manifest themselves in rituals. At the same time, similar to an organism that embeds itself into the pathisch relation with life itself, one's life has its roots in the depths of the realm of the wild, a phase different from that of the ontic being/existence. 
Consequently, the umwelt that most people directly perceive as their milieu can be imagined as having a fluid, vague border, gradually extending from the realm of jogga, with its various tangible beings, to the dim and unknown realm of māya filled with śakti.

However, even in the realm of jōga, or the experiential umwelt, villagers are not fully free of uncertainty, because they cannot foresee when and what sort of changes and crises will happen to them, and hence cannot completely control their lives. In terms of the Gestaltkreis theory, this contingency and uncontrollability reveals the pathisch attribute of their lives.

At the same time, as will be described later in this book, when encountering events and vicissitudes in the realm of jōga, people often become aware of the possibilities that these vicissitudes emerge from their relationship with the realm of māya. Therefore, people try to undertake and deal with the power of māya by ritually appeasing the wild śakti, consulting astrologers, and interacting directly with bütas in rituals. Through these performances, people sense that the dim edge of the realm of jogga is not the end of the world, but is connected to the realm of the unknown; and at the same time, they endeavour to look into the depths beyond the fringe.

Sensitivity to the realm of māya, fear of and care for the wild divinity that forms and orients their lives, and actions towards sakti that appear at the border of tangible and intangible - all entangled with daily social relations - are part of the formative relationships between people and the umwelt.

As will be described, jostled by things such as the introduction of modern legal systems, land reforms, and massive development projects, village communities in South Kanara have been undergoing changes. In the process of historically recent change, which is usually glossed as 'modernisation', the villagers encounter and interact with various new actors who have appeared in their daily lives. This process has also led to changes both in the customary ways of doing things and in the daily social relations among villagers, creating new systems and organisations which embody unfamiliar logics and values.

In the long historical process, these jostling events are regarded as the crises that transform relations among various beings in the realm of jogga, and that transform the umwelt and the lives of villagers. The villagers have created and recreated their forms of life within historical circumstances. Using what they know, they have reconstructed and adapted familiar forms of life while encountering and interacting with other forms of life based on new logics, systems, and ways of doing things. All the while, however, their relationship with the realm of māya, even though it has also noticeably changed, has remained significant in their daily lives. In the ethnography that follows, focusing on the practices of people who in the wake of crises have maintained, temporarily lost, or newly created relationships with the wild and with deities, I investigate the mutual formation and transformation of people's lives and their umwelt. 


\section{The organisation of this book}

This book comprises two parts. Before summarising each chapter, I will provide an overview of these two parts.

\section{Part One: the relationships between bütas and villagers}

In the first half of Part One (Chapters 2-5), I describe the daily life of villagers, their customary laws and social organisation, and the features of būta worship in Perar. Būta worship in South Kanara has developed as a sophisticated system closely linked to hierarchy, matriliny, land tenure, and the distribution of farm products in village society. It is based on oral mythological epics ( $p \bar{a} d d a n a)$ and customary law (kattu u). At the same time, the core of büta worship, which creates its actuality, is composed of the direct encounters and interactions between people and deities.

Following this consideration of the villagers' umwelt, focusing on the villagers' relationship with deities through spirit possession, the second half of Part One (Chapters 6 and 7) refers to several anthropological studies of human-nonhuman relations to examine the relationship between būtas and people in this village society. My primary focus is the transaction of offerings and blessings between humans and deities. Gift-exchange between humans and deities, which forms the basis of the relations between the people and their umwelt, also points to the intersection of the Gestaltkreis theory and anthropology.

As described earlier, one of the important themes of the Gestaltkreis theory is how encounters and interactions occur between an organism and its umwelt, and likewise in social contexts, how a person encounters others. These encounters have been a central concern of anthropology too, although in anthropology, the 'others' in these encounters and interactions are not necessarily human. Indeed, ethnography abounds with informants who mention nonhuman beings such as rivers and mountains, plants and animals, and deities and spirits as the 'others' with whom these informants have significant interactions.

The relationship between human and nonhuman beings has been investigated in anthropological studies on magical-religious practices such as animism, shamanism, and spirit possession. Studies of gift-exchange and personhood have also elaborated important arguments about the unfolding of encounters and interactions between people and others, including nonhuman beings. ${ }^{28}$ Moreover, as seen in the OT, anthropological studies of unique relations between humans and nature, and of gift-exchange and personhood, have been invigorated through connections to studies on humannonhuman relations in related fields. ${ }^{29}$

This book begins its theoretical investigation with reference to the works of Marriott (1976) and Appadurai and Breckenridge (1976), who examined the characteristics of transactions in South Asian societies and proposed 
a number of influential concepts such as substance-code, dividual person, and transactional network. Applying these concepts to the analysis of büta worship in South Kanara, I discuss their limited usefulness. Casting a wider net, I also closely examine several studies beyond South Asian societies for clues to investigating human-nonhuman relations in order to consider the formation and transformation of one's self through interactions with būtas. My discussion includes the work of Strathern (1996), who examined the formation and limitation of networks created by the transaction and circulation of substances, as well as the work of Viveiros de Castro (1998, 2004b) and Willerslev $(2004,2007)$, who investigated the exchange of perspectives between humans and nonhuman others.

\section{Part Two: people and deities undergoing social change}

In Part Two, the focus shifts to the relationships among people, land and nature, and deities, through an examination of the multiple practices of people who have been dealing with events that have brought about enormous change in village societies. Through close investigations of various villager practices, and of conflicts and turmoil leading to crises that engender the reorganisation, transformation, and dismantling of daily social relations, I seek to explain continuities and transformations in the relationships between villagers and their umwelt.

As alluded to above, būta worship in South Kanara is a sophisticated system linked to family ranks and associated duties, matriliny called aliyasantäna kattu,,${ }^{30}$ and land tenure. Since the nineteenth century, it has been influenced by the state administration of religious institutions and, especially affecting land holding and matriliny, by the transition to modern law. Regional management of religious institutions in South India, for example, following the Madras Hindu Religious Endowments Act of 1927, critically brought new actors - administrators of the laws of the state - into the province of büta worship, where the deities themselves had heretofore been regarded as the supreme actors.

Land reform after independence, with its redefinition of matriliny in modern law and its surveys and registration of land held by matrilineal joint families, also transformed būta worship, which was rooted in land holding and matriliny. More recently and dramatically, since the mid-2000s, owing to the construction of petrochemical plants in a designated special economic zone, village communities in Mangaluru taluk have been faced with relocation and destruction.

Most previous studies have looked at events such as the enforcement of modern law, modification of indigenous systems of land tenure and inheritance, and exploitation of land as major elements in the process of social change caused by modernisation. Studies of institutional changes in Hindu temples have specifically described the collapse of transactional networks among kings, priests, and deities with the advent of colonial power, which 
brought the ruination of traditional kingship and involved temples in state administration (Appadurai 1981; Fuller 1984; Dirks 1987). Other studies examining the influence of various systems of land tenure introduced in colonial India have described how these wrought fundamental changes to traditional social systems based on a 'system of entitlements ${ }^{31}$ (e.g. Tanabe 2006). Regarding the būta rituals in South Kanara, some writers have observed how following the land reforms in the 1970s, a decline in the power of local landlords who had traditionally played a central role in organising būta rituals led to a qualitative transformation in how būta worship is performed (Rajan 1986, p. 54; Gowda 1991, p. 18).

Crises also ensue with the closer integration of local societies with national and global markets: most studies of development projects have described local communities being damaged by top-down development projects and environmental destruction. Within this literature a number of studies have, in the context of grassroots democracy, analysed popular movements against exploitation. $^{32}$

As will be described, people in South Kanara who engage in būta rituals have experienced historical and institutional changes similar to those described in previous studies. As mentioned, the state administration of religious institutions in the colonial period brought new actors into the province of buta rituals, which had been based on oral epics and direct interaction with bütas. The appearance of new actors armed with the authority of modern law sparked numerous disputes over the management of būta shrines. When matriliny and land tenure were redefined and codified by modern law, and when the land reforms that followed independence were enacted, systems of land tenure and matriliny which had supported būta rituals were reorganised. Now, as largescale development has given rise to antidevelopment activism, the current crisis for būta rituals in village societies may mark another major turning point.

With these historical, institutional, and socio-economic changes, the relations that villagers form with various others have also been reorganised and partially transformed. As I argue, however, the transformation and dynamism within village society and būta worship cannot be interpreted as simply a unilateral process, as the dissolution of a traditional society or the decline of 'the religious world' through modernisation. Neither can we assume that the systems, notions, and modes of being, which embody modern values and logic, simply subsume or cancel out their traditional counterparts based on spiritual beings and transform them into a modern political 'reality' within its ensuing narrow ontological limits (cf. de la Cadena 2015, pp. 273-283).

My ethnography explores both the conflicts and frictions between customary and modern systems and ways of life and the interactions and reflexive relations between them. I also investigate the process of the formation and transformation of transactional networks between people and deities in crises that ensue when systems and modes of being embodying different logics, values, and histories encounter each other and thereby precipitate conflicts and negotiations. 


\section{The chapters of this book}

Chapters 2 through 5 closely examine the relations among people, land and nature, and deities in their milieu to begin to elucidate the umwelt of the villagers living in rural South Kanara.

Covering aspects such as social composition, production, regular vocations, and villager relations with land and nature, Chapter 2 outlines daily life in the villages in Perar. Chapter 3 focuses on the village butta shrine, the largest religious institution in Perar. Describing the religious duties of the 16 manor houses, and of the priests and dancer/spirit mediums at the shrine, I will clarify the relevant details of the customary laws and systems that form the basis for būta worship in the village. Chapter 4 then provides pertinent information about the păddana, or oral epics, which describe the origins of the deities and are drawn upon to ascribe the ranks and ritual duties of Perar families. In Chapter 5, details of the yearly ritual at the village shrine will be clarified through a discussion of the interaction between people and būtas in the rituals. It will become apparent that while the mutual rights and duties of the villagers and deities are updated through the transactions of offerings and blessings, the ranks and rights of the people can be somewhat destabilised by the bütas, who are the supreme actors.

Chapters 6 and 7 include theoretical explorations of the relationship between villagers and deities. Chapter 6 deals with an agricultural ritual called kambula and the annual nema ritual in Perar. Applied in the analysis of these rituals are the notions of substance-code, dividual persons, and transactional networks proposed by Marriot (1976) and Appadurai and Breckenridge (1976). Referring to Strathern (1996), the formation of transactional networks between people and deities, the circulation of substance-codes, and the limitations of the network will also be described. After this, by focusing on the experiences of spirit mediums who transform themselves into deities during rituals, Chapter 7 investigates the direct interactions between people and būtas. Drawing on Gestaltkreis theory and notions of perspectivism (Viveiros de Castro 1998, 2004b; Willerslev 2004, 2007), I will consider these interactions as playing with multiple perspectives.

Chapter 8 provides a bridge from Part One, which explains the characteristics of būta worship and its role in people's lives in a village society, to Part Two, which examines the dynamism both of village society and of būta rituals in the face of social change. This examination requires an investigation of 1930s legal disputes over the trusteeship of the büta shrine in Perar. I will then examine a series of disputes that occurred in the 2000s between an influential family in Perar and a newly established management committee for the village shrine. Through this investigation, I will explore how people have attempted to reorganise social relations around būta rituals, betwixt and between legal rulings from law courts and divine orders from deities. Chapter 9, as a preparatory step for a close analysis of the relations among people, land and nature, and büta worship in subsequent chapters, 
will discuss historical changes in land tenure in South Kanara. Following an overview of land tenure system in pre-colonial South Kanara, I will clarify the characteristics of the ryotwari (raīyatwāri $)$ system enforced under the Raj in South Kanara and analyse the assessment of land and registration of landholders in Perar based on an official document published in the early twentieth century. Lastly, I will provide a brief overview of the influence of land reforms in post-independence South Kanara.

Matriliny, especially how it has been defined under modern law and how villagers have adapted to its changes, comes under scrutiny in Chapters 10. As already mentioned, būta worship is closely related to the matrilineal system called 'aliyasantāna kațț̣'. The Baṇța landlords in the area are the main organisers of the būta rituals at village shrines, as each generation inherits ritual duties and worships family būtas within the kutuma. While kuțuma (kutumba, in Kannaḍa) can be glossed as 'matrilineal joint family', it is more than this; it is a complex entity encompassing a core, head family that has a family būta shrine and several other households, land, and members who are taken to be matrilineal descendants of common female ancestors. That is to say, kutuma is both a historical notion that reaches back to the origin and lineage of a matrilineal joint family and a spatial notion which includes houses and land bound by būta rituals (cf. Moore 1985).

As Chapter 10 will show, in South Kanara since the nineteenth-century legal redefinition of aliyasantāna kațụ, kuṭuma has been reinterpreted in modern law as an indivisible 'community of property'. After independence, rules of inheritance for family property and the rights of individual successors were regulated by new laws. Baṇta landlords, who traditionally held most of the land, have been greatly affected by this legislation. Focusing on the Mundabețtu guttu, an influential family in Perar, I will describe how village-dwelling Banta landlords dealt with the changes brought by the Madras Aliyasantana Act of 1949 and other laws enacted since then. The 1949 Act required members of a kuțuma, who had maintained a loose unity based on the practice of butta rituals and their common ownership of land, to stipulate the land rights of each member. I will describe the careful thought given to the ways a Banța family strove to maintain the kutuma as the comprehensive and integral basis of their life and, at the same time, to reorganise it to conform with modern law.

In Chapter 11, I will investigate the effects of the 1970s land reforms, focusing on the responses and experiences of villagers in Perar and on how the changes have affected būta worship. It is necessary to consider the relationships between ordinary farmers and landlords, whose land rights have been authorised through their position as the organisers of büta rituals pertaining to particular lands. We also have to investigate how the būtas, regarded as the fundamental 'owners of land', have influenced villager practices and decision-making following the land reforms. Land reforms enforced by the government were more than just an intervention into the conventional land tenure system in village society; the new laws also affected how people 
related to their families, neighbours, lands, and deities, and they compelled a reorganisation of existing systems and relations. The reorganisation of their social relations linked with land makes clear the villagers' efforts to maintain and renew their relationship with particular lands and deities while coping with the demands of modern law.

Chapters 12 and 13 will discuss the influence of the development projects around Perar. Since the mid-1980s, a series of such projects have greatly affected the lives of villagers through their large-scale land acquisition and destruction of fields and villages. Here, we see how villagers have coped with deforestation and the fragmentation of village communities. How do būta rituals figure into villager responses, both positive and negative, to development projects? How are the outsiders who implement development projects related to the land, inhabitants, and deities in the area? Regarding these questions, the following three topics will be discussed: butta worship in antidevelopment activism, conflicts arising from the development projects and the effects of the būtas' agency, and the occurrence of büta worship inside an industrial plant. In Chapter 12, I will consider the ambivalent influence of the būtas, who both strongly support antidevelopment activism by ordering a 'desperate defence of land and shrine' and, at the same time, bind people to their land. Chapter 13 examines new manifestations of būta worship within industrial plants in the special economic zone. It will be shown that interactions between the deities and industry managers have come into being, and that new transactional networks between workers and būtas have also been created in industrial plants. These generally form when the industrial zone experiences a calamity of some kind, an event that is interpreted as a manifestation of the buta power that dwells in the land. Finally, Chapter 14 provides a conclusion to the entire book.

\section{Fieldwork particulars}

The fieldwork for this study was undertaken for a total of about 17 months and was conducted during periods between May 2008 and March 2015. In 2007, when I made my first short visit to Mangaluru, I learned of the būta deities. Visiting Mangalore University, I happened to meet a sociology student. Hearing of my interest in indigenous religion and spirit possession, he showed me a book published at the beginning of the twentieth century. I was fascinated by a monochrome portrait on one of the pages. It was a photograph of a būta ritual dancer, dressed in a costume made from palm leaves, looking out from the page with a hard look. ${ }^{33}$

Although I was unable to observe any butta rituals during this first trip, my interest was further piqued when I visited Mangaluru again in June 2008. For the first two months, try as I might, I could not settle on a suitable place to study. It was the rainy season, which is not a popular time for butta rituals. The situation changed for the better when I met Professor Chinnappa Gowda, a folklorist at Mangalore University. He introduced me to 
Ms Akshaya Shetty, who had just completed a master's course in folklore studies under his guidance. She told me that she was from a village famous for a unique and historic būta ritual, and that her father's family was in charge of it. Soon thereafter, she took me to her village, a place with wide sweeps of green rice fields surrounded by deep forest filled with birdsong.

I then decided on Perar as the base for my fieldwork. During this fieldwork period in 2008, I commuted an hour each way between the city centre and the village every day. I was unsure about taking up residence in the village because I was accompanied by my four-year-old daughter. In 2009, surer about how to live in the village, I stayed in Perar with my daughter and husband. We were privileged to be allowed to stay in a guest house owned by the Mundabetțu guttu family, the matrilineal joint family on Akshaya's father's side, which was located in the same compound as Akshaya's house. Since then, I have continued my fieldwork in Perar and neighbouring villages greatly aided by Akshaya, her mother Baarati, and her father Harisha.

\section{Notes}

1 South Kanara (Dakșina Kannada) is a region located between the Western Gāts and Arabian Sea, which extends across Udupi and Dakshina Kannada districts in Karnataka state and Kasaragod district in Kerala state (see Bhat 1998, pp. 4-6). Though the official language of Karnataka state is Kannada, the native language of most inhabitants in South Kanara is Tulu, and this region has been called Tulunāḍu. The month of māyi in the Tulu calendar corresponds to between 15 February and 15 March in the solar calendar.

2 Śakti generally denotes the divine power of deities. Specifically, it refers to the power, potency, or activating energy incarnated in goddesses (Tanaka 1997, p. 148; Fuller 2004, p. 44). Also, prakrti in Tulu refers to nature, the natural state of anything, the root, cause and origin (Upadhyaya 1988-1997, p. 2161). This word originates from the Sanskrit word prakriti, which refers to a goddess as well as to nature, and hence it is synonymous with śakti (Monier-Williams 2008[1899], p. 654). Both śakti and prakriti indicate the inseparability of nature and divinity and the ambiguous power of goddesses.

3 Mangaluru has been called Mañgaḷuru in Tuḷu and Mangalore in English. On 1 November 2014, the state government of Karnataka changed the rendering of the official name of the taluk from Mangalore to Mangaluru. Though I generally use 'Mangaluru' in this book, I also use 'Mangalore' when quoting previous studies and official records or to conform with the name of an institute. In this book, I have changed the names of some places, informants, and families, and have used abbreviated designations for companies such as 'SK' and 'CS' to protect their identities.

4 In this book, 'Perar' denotes Mudu Perar and Padu Perar as a whole. As becomes apparent in Part One, in many ways, these two villages are regarded as a complementary pair.

5 The notion of 'the realm of the wild' here overlaps with prakrti which denotes the power of goddesses. As described later, it is an unknowable realm filled with the śakti of deities.

6 The Sanskrit word prasāda indicates serenity, benevolence, and grace; offerings from the deity's altar is also called prasāda (Monier-Williams 2008[1899], pp. 696-697). In Tuḷu, prasāda indicates blessings from deities; generally, 
offerings such as flowers, food, and sandalwood paste which are presented to deities and then given to devotees are called prasāda (Upadhyaya 1988-1997, p. 2170).

7 For important studies on the relation between modernity and the occult, see also Comaroff and Comaroff (1992, 1993, 2001, 2002), Behrend and Luig (1999), Moore and Sanders (2001), Masquelier (2002), and Pels (2003). Boddy (1994) also reviewed anthropological studies on spirit possession, focusing on the dimension of 'resistance' against oppressive social changes such as modernisation and colonisation. See also Ishii (2007), as a critique of the theoretical framework of these previous studies.

8 See also Geschiere (1999) and Meyer (1999). Needless to say, even before the $1990 \mathrm{~s}$, there were some studies which considered the occult in non-Western societies as the expression of people's ambivalent consciousness towards modernity. See, for instance, Fabian (1978).

9 For critiques of this tendency, see Englund and Leach (2000), Ishii (2005), and Ranger (2007).

10 For various theoretical trends in anthropology concerning ontology, see Vigh and Sausdal (2014), Gad, Jensen, and Winthereik (2015), Kohn (2015), and Jensen et al. (2017).

11 Henare, Holbraad, and Wastell (2007) cite Bruno Latour, Alfred Gell, Marilyn Strathern, Viveiros de Castro, and Roy Wagner as anthropologists who have indirectly led the ontological turn. In this book, I concentrate on Viveiros de Castro, who often refers to and leads arguments on the ontological turn, as a primary proponent of the OT.

12 Naturally, proponents of the OT criticise any consideration of these magicalreligious practices and discourses as mere 'beliefs' (see Viveiros de Castro 2011a, p. 136).

13 The rationality debate involves a series of arguments concerning the criteria for rationality as well as the differences and compatibility between systems of modern thought and 'primitive thought'. See Wilson (1974), Tambiah (1990), Horton (1993), and Stambach (2000).

14 Viveiros de Castro has offered a refutation of this critique (2011a, pp. 135-137).

15 In contrast to studies that assume the modernity of colonial and postcolonial states, Pedersen (2011, p. 67) sees the post-socialist Mongolian state as magical, shamanistic, and non-modern.

16 See, for instance, Asad (1986), who, in discussing the translation of culture, criticised the objectivist view of Gellner (1970). While appreciating the view of Asad, Viveiros de Castro proposes the idea of 'controlled equivocation' as a better understanding of translation (Viveiros de Castro 2004a, p. 5).

17 As an exception, Henare (2007), one of the editors of Thinking through Things (Henare, Holbraad \& Wastell 2007), uses the idea of 'commensurability' when considering the life of Maori people, who shift between modern and traditional registers of value and property.

18 Deleuze writes,

Bergson means that the objective is that which has no virtuality - whether realized or not, whether possible or real, everything is actual in the objective ... Matter has neither virtuality nor hidden power, and that is why we can assimilate it to "the image".

(1991, p. 41, emphasis in original)

19 Regarding this, Holbraad writes, 'My central argument turns on the idea that alterity proper must be construed in ontological rather than epistemological terms. The questions that alterity poses to us anthropologists pertain to what 
exists rather than what can be known' (2009, p. 81, emphasis added). Also, Holbraad (2007, pp. 208-217) considers Cuban divination in which deities move from transcendent to immanent to communicate with humans, using the notion of potentiality. This view is similar to my discussion in later chapters of būtas, which appear at times between the virtual and the actual. Holbraad, however, focuses on how a diviner makes the transcendent deities manifest as immanent beings. Likewise, critiques (e.g. Viveiros de Castro 2014a) of the view of those anthropologists who approach witchcraft, spirits, and other magical-religious phenomena as if they do 'not really exist' are, in effect, making an ethical request that anthropologists treat these as phenomena that have real being/existence for the people in the field.

20 'Coherence' (Kohärenz) is one of the key concepts in von Weizsäcker's thought (1997[1950]). The term indicates the chiasmic relation between an actor and its umwelt, as well as its transformations; the characteristics of the umwelt are specified and transformed by a certain mode of action, and at the same time, the mode of the act is specified by the characteristics of the umwelt that emerges in the action (see Kawamoto 2006, pp. 82-83; Ishii 2012).

21 All following English quotations in this chapter from German sources are my own translation.

22 Or, as discussed in Chapter 7, an organism may maintain its stability by disregarding or 'overlooking' some of the changes of the umwelt (von Weizsäcker 1997, pp. 108-109).

23 Kimura discusses the distinction between the verbs aru (exist) and iru (stay) in Japanese. According to Kimura, aru corresponds to 'be', sein, and être, which are verbs as well as copulas, and it primarily denotes the existence of things and abstractions not including animate beings. Meanwhile, iru is a verb which denotes the 'staying' or 'dwelling' of humans, animals, and other personified beings. In this sense, aru-mono (existing thing/being) is considered to be either real or possible, while iru-mono (dwelling thing/being) is considered to be either actual or virtual (Kimura 2000, pp. 70-73). From this perspective, a būta which appears temporarily between the realms of the wild and the human is considered not as an aru-mono, but as an iru-mono.

24 Therefore, the process of the development of an organism seems to anticipate the order of its umwelt. This corresponds to the view of Merleau-Ponty that the actions of an organism are endowed with a 'reference to the future'. See Hirose (1997).

25 For the social dimension of the Gestaltkreis theory, see also von Weizsäcker (2005).

26 In general, jōga refers to the physical world, the human form, existence, and reality, while māya means 'mystery' and 'disappearance'. Also, māyaka denotes vanishing, fleeting, passing away, and disappearing. It is thought that while būtas belong to the invisible realm of māya, they temporarily manifest themselves (jöga äpini) through spirit possession. Additionally, bütas have the power to make others vanish (māya malpuni). See Upadhyaya (1988-1997, pp. 1339, 2566, 2567), Claus (1978, pp. 9-10), and Brückner (2009, pp. 44, 77, 133).

27 In this sense, būta śakti in the realm of māya is considered to be virtuality, while what appears in between the realms of māya and jōga is actuality. Kimura (1997, pp. 98-101) had this to say about the relation between actuality and virtuality: virtuality is the state in which actuality has not yet been actualised. It denotes the state in which virtuality has not yet unfolded its virtue. Actuality arises only between itself and virtuality, or as its difference from virtuality. See also Ishii (2012).

28 For anthropological studies on personhood, see Carrithers, Collins, and Lukes (1985), Jackson and Karp (1990), and Lambek and Strathern (1998). 


\section{Introduction}

On personhood in South Asian societies, see Dumont (1965, 1980), Daniel (1984), Mines (1988, 1994), Busby (1997), Freeman (1999), and Sax (2002). For studies on gift-exchange in South Asian societies, see Parry (1986, 1989, 1994), Raheja (1988), Osella and Osella (1996), Laidlaw (2000), and Copeman (2005, 2009, 2011).

29 In addition to the works of the ontological anthropologists discussed in the previous sections, see Bird-David (1999), Ingold (2000), Willerslev (2004, 2007), Kohn (2007, 2013), and Candea (2010).

30 Aliyasantāna kattụ, also known as aliyakattu, indicates the matrilineal system of inheritance. In Tulu, aliya indicates 'nephew' or 'son-in-law', and santāna indicates 'line' or 'family'. See Upadhyaya (1988-1997, pp. 212, 2865).

31 Regarding this, Tanabe writes,

In the pre-colonial "system of entitlements", members in a local community were granted various rights to shares of the local products and the royal and/ or community honours and privileges in lieu of performing different duties and functions for the reproduction of the state and community.

(Tanabe 2006, p. 767)

32 See, for instance, Shiva (1988), Gadgil and Guha (1992), Arnold and Guha (eds.) (1995), Swain (1997), and Guha (2000).

33 This was one of the pictures of būta dancers in Thurston (1975[1909c], pp. 141-148), with the caption 'Nalike devil-dancer'. 


\section{Part One}

\section{Humans and the wild śakti of deities}



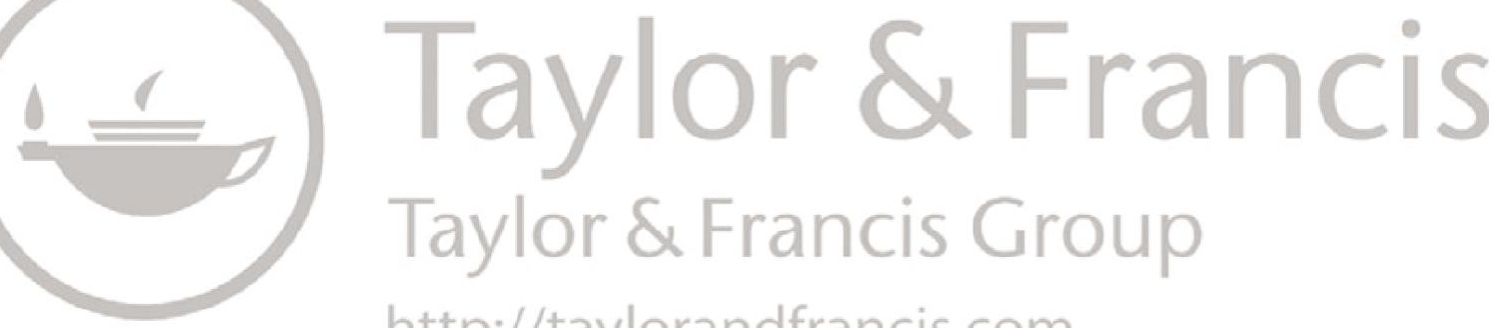

http://taylorandfrancis.com 


\section{The land of paddy fields, forests, and deities}

One must travel about 30 kilometres inland from Mangaluru, the capital city of Mangaluru taluk, to reach the adjoining villages of Mudu Perar and Padu Perar. On a rainy day in early July 2008, I made my first visit to Mudu Perar guided by Akshaya. We took an express bus from the central bus station in Mangaluru. The bus ascended and descended along winding roads through hilly forests, crossed the Gurupura River, passed several villages and extensive paddy fields, and within an hour arrived at a small town called Kaikamba. We transferred to a local bus at the town station, navigating around crowds of people, auto-rickshaws, and small shops and stalls. We squeezed onto a local bus packed with passengers that headed slowly towards Bajpe. After ten minutes, we got off this bus at a place called Ishvarakatte, which is the entrance to Mudu Perar. Since it is on the top of a hill, from one side of the road, I could look out over the deep forest below. On the other side of the road, there was a narrow street that led to the inner village. Several small shops, including a general store, grocery, teahouse, tailor, and barber, lined both sides of this narrow street, and a yellow auto-rickshaw was parked on one side.

We called the driver over and got into the back seat of the rickshaw. It took us down the street, which was soon lined by houses surrounded by hedges. A steep downhill road brought us to end of this row of houses, where my field of vision suddenly expanded. Stretched before us as far as the eye can see were vast green paddy fields. There were a few houses under palm groves over the fields, and in the distance, I could just make out the deep forests and hills surrounding these lowlands. Startled snowy herons took off from one paddy field as we careened down the hill at full speed. At the bottom of the hill, we extracted ourselves from the rickshaw. We had reached the geographical centre of Mudu Perar.

In this chapter, I will provide an outline of my main research field, Perar. First, I will elucidate the relations between Mudu Perar and Padu Perar. Second, I will provide a general overview of the social composition of both villages. Finally, I will describe how the land is used and the relationships that exist among land, nature, and büta worship in this area. 


\section{Mudu Perar and Padu Perar}

Mudu Perar and Padu Perar are adjacent to each other and each has roughly the same area. ${ }^{1}$ These villages are connected by a main road and countless footpaths used daily by the villagers. As already mentioned, these villages once comprised a single village, and though they were administratively separated in 1904, they are still collectively called 'Perar' by the villagers. 'Mudu Perar' and 'Padu Perar' literally mean 'East Perar' and 'West Perar', and they are alternatively called the 'lowland (tirtakare)' and 'highland (mittakare)', respectively. These names show that the villages are still conceived of by the villagers as an inseparable pair. ${ }^{2}$

According to the oral epic (pāddana), the origin of Perar can be traced all the way back to a mythical period, and every part of the land is suffused with the relationships between the people and the deities. For instance, the territory of Perar spans from Aggidaimata to Dambepāpu, and it is said that the area between these two places was the space covered by Balavanndi, the main deity of the village shrine, when he stood with his feet set apart. The border of Perar was thus determined by Balavāṇḍi, and likewise, most places there were also demarcated and named in relation to deities.

As we will closely examine in Chapter 4, it is said that about 800 years ago, Balavāṇ̣̂i disguised himself as a human being and appeared in Perra (the old name of Perar). He visited several houses in the village and made the then head of each house promise to construct a village būta shrine. Gangādara Rai, who is the present head of the Mundabettu guttu, ${ }^{3}$ the highest-ranked local manor house in Perar, narrated this mythical event as follows:

The daiva [an honorific for a būta] first appeared at the house of a Brahman family called Pejattāya. Then, the daiva came to this house. Firstly, three visitors wearing turbans came and asked for a drink of water. A Jain woman called Koratāi Balardi, who was then the head of the Mundabetțu guttu, gave them milk to relieve their thirst. As soon as they had finished drinking it, they vanished. That night, the daiva appeared in her dream and told her, 'We are the ones who asked for water this morning. We are deities. We came here because we have a request for you.' She then asked them, 'What help do you need?' The daiva replied, 'We came here to protect this village and make it prosperous. You must establish sixteen guttus in Perra, and the Mundabețtu must be the first one. You must also found two villages, East Perra and West Perra, with eight guttus each. These families must organize an annual festival (nēma) for us. The Mundabetțu guttu will be central, as this is the land of my origin (mūla stāna). For the people of Perra, you must construct a shrine at the centre of the village.' For this reason, the village shrine was constructed for the people. In this way, it has continued till today.

(Gangādara Rai, 2 July 2008)

As seen in this narrative, the division of Mudu Perar and Padu Perar, and of the 16 manor houses or guttus presiding over the land, was said to be 
determined by Balavāṇdi. For the villagers worshipping būtas, the religious centre of Perar is the shrine of the village deities (grāmada daiva) located near the border of Mudu Perar and Padu Perar. The members of the guttu families are responsible for guiding the other villagers to organise rituals at the village būta shrine. As seen above, from the mythical time of the oral epics through today, Mudu Perar and Padu Perar have been inseparable from each other regarding būta worship.

\section{The social composition of Perar}

According to a document at the village panchayat in Padu Perar, as of 2001, the population of Mudu Perar is 4,951 (2,307 males and 2,644 females), and that of Padu Perar is 3,520 (1,719 males and 1,801 females). ${ }^{4}$ Table 2.1 shows the number of households based on religious affiliation in Mudu Perar and Padu Perar, respectively. ${ }^{5}$ In Mudu Perar, the number of Hindu households accounts for over the half of the total, and they are followed by Muslim and then Christian households. In Padu Perar, the number of Hindu households is over $70 \%$ of the total households, and they are followed by Christian and then Muslim households. Though Hindu households are the majority in both villages, it is notable that in Mudu Perar, Muslim households account for over 30\% of the total. Most of the Muslims reside in a community called Guru Kambula, located on the southern end of Mudu Perar. The Christians, all of whom are Catholics, do not reside in a particular place but are scattered throughout the village. ${ }^{6}$

Table 2.2 shows the $j a \bar{t} i$, or caste group, structures in Mudu Perar and Padu Perar. This table shows that the communities with the highest proportion of the population in both villages are the Kuḍubi, Pūjāri, and Banța. Among the communities represented in this table, except for the Brahman, the Pambada and other Scheduled Castes, and the Koraga as the Scheduled Tribe, all groups are designated as Other Backward Classes (OBC) in the state of Karnataka. ${ }^{7}$ Below I will outline the communities important to būta worship in Perar.

Table 2.1 The number of households based on religion in Mudu Perar and Padu Perar

\begin{tabular}{llcc}
\hline & Religion & $\begin{array}{c}\text { Number of } \\
\text { households }\end{array}$ & $\%$ \\
\hline Mudu Perar & Hindu & 689 & 53.2 \\
& Muslim & 439 & 33.9 \\
& Christian & 166 & 12.8 \\
& Total & 1,294 & 100 \\
Padu Perar & Hindu & 619 & 70.5 \\
& Muslim & 94 & 10.7 \\
& Christian & 165 & 18.8 \\
& Total & 878 & 100 \\
\hline
\end{tabular}


Table 2.2 The number of households based on caste group in Mudu Perar and Padu Perar

\begin{tabular}{|c|c|c|}
\hline & Caste & Number of households \\
\hline \multirow{14}{*}{ Mudu Perar } & Kuḍubi & 260 \\
\hline & Pūjāri & 167 \\
\hline & Banța & 128 \\
\hline & Moyli & 34 \\
\hline & Ācāri & 31 \\
\hline & Other Scheduled Castes* & 26 \\
\hline & Konkani & 11 \\
\hline & Brahman & 10 \\
\hline & Puruṣa & 6 \\
\hline & Belcade & 6 \\
\hline & Mūlya & 5 \\
\hline & Pambada & 1 \\
\hline & Others** & 4 \\
\hline & Total & 689 \\
\hline \multirow[t]{16}{*}{ Padu Perar } & Banța & 148 \\
\hline & Pūjāri & 147 \\
\hline & Kudubi & 144 \\
\hline & Brahman & 32 \\
\hline & Ācāri & 23 \\
\hline & Konkani & 20 \\
\hline & Moyli & 18 \\
\hline & Other Scheduled Castes* & 18 \\
\hline & Pambada & 13 \\
\hline & Purușa & 11 \\
\hline & Maḍdyele & 11 \\
\hline & Belcade & 9 \\
\hline & Mūlya & 8 \\
\hline & Koraga & 6 \\
\hline & Others** & 11 \\
\hline & Total & 619 \\
\hline
\end{tabular}

* Households belonging to SC aside from Pambada.

** Caste groups which consist of less than three households (excluding SC).

\section{Banța}

In Tuḷu, Banța are also called Banțerụ or Okkelakuḷu. ${ }^{8}$ In South Kanara, influential families of Banța have been the landlords of the local manors called guttu. They have also played an important role in village society as patrons of the būta rituals. Banța follow the matrilineal system called aliyasantāna kațtu, and they have matrilineal exogamous groups called bari. The kuțuma, or matrilineal joint family, usually maintains strong internal ties. Inheritance, succession, and primary life rituals are conducted essentially within the kuṭuma. In each kuțuma, the head house has a būta altar (mañcāvu) in its main hall (cāvadi), and it is of central importance. While most Banțas living 
in rural areas make their living in agriculture, it has also become prevalent among Banțas since the 1970s to migrate to mega-cities such as Mumbai or Bangalore to engage in various businesses.

\section{Kudubi}

Kuḍubi are also called Kuḍubi-Gauḍa. They follow the patrilineal system called makkala kattu, and their ancestors are said to have come from Goa. In Mudu Perar, there is a Hindu shrine worshipped by Kuḍubis called Śāstāvu Bramma. Also, they worship several butta shrines at the head house of the main patrilineal family. One Kuḍubi family living in Śāstāvu is the 13th ranked of the 16 guttus in Perar, and they have a duty to provide new clay pots for the annual festival at the village būta shrine. Before the land reform legislation was implemented in the 1970s, most Kudubis were not landed farmers but tenants (gēni okkelu) and domestic labourers (kāli okkelu). ${ }^{9}$

\section{Püjāri}

Pūjāri are also called Billava or Bayidya. Like Baṇṭa, Pūjāri follow a matrilineal system. In South Kanara, they have traditionally made their living as toddy tappers, and they have played an important role in büta worship as priests called pātri or māni. In Perar, Pātri priests are engaged in būta rituals as mediums of a lower rank than the Banța priest called the mukkāldi. Among the 16 guttus in Perar, Pūjāri families have the 14th through the 16th ranks. Before the land reform legislation was implemented in the 1970s, most Pūjāris were involved in farming as tenants and domestic labourers, in addition to their toddy tapping. ${ }^{10}$

\section{$\bar{A} c \bar{a} r i$}

Ācāri follow a patrilineal system and have traditionally made their living as carpenters. In Perar, they are now both goldsmiths and silversmiths, and they also use their vocational skills to make and repair sacred objects for būta rituals. One duty of the head house of the Ācāri family in Mudu Perar is to make a wooden gate for the yearly ritual at the village būta shrine. They also offer four wooden spoons made from a piece of palm tree to the goddess Māri. Most Ācāris in Perar have been engaged in farming as tenants. ${ }^{11}$

\section{Moyli}

Moyli are also called Sapalya, Sērigāre, and Dēvaḍige. They follow a matrilineal system and have matrilineal exogamous groups. In Perar, the male members of one particular Moyli family have played important roles in būta worship as ritual servants (cākiridakulu) of the village būta shrine. They are 
the carriers of sacred objects in the annual festival, and one Moyli man who carries one būta's mask (muga) is possessed by the deity in the ritual.

\section{BattrụlBrahman ${ }^{12}$}

Brahman follow a patrilineal system and are said to have come to Perar from Ahi-Kshetra ${ }^{13}$ to the west coast of South India around $750 \mathrm{CE}$. In Perar, Brahman have ranked alongside Banța as the major landholders. While Brahman priests conduct religious rites mainly in Hindu temples, they also work for būta shrines. In one būta shrine called brammere guṇda (Bramma's sanctuary, hereafter Bramma guṇa) located on the precincts of the village būta shrine, a Brahman priest called an asrānṇa conducts daily services. Also, a Brahman family called the Pejattāya occupies a higher position than the 16 guttus, which consist of Baṇța, Pūjāri, and Kựubi.

\section{Purușa}

Puruṣa are also called Jōgi. In Perar, one particular Jōgi family has been engaged in playing music and has played an important role in būta worship. They follow a patrilineal system and their occupation and training as musicians is succeeded from father to son. They play traditional drums and a wind instrument called a kombu. They have also recently taken up Western instruments such as the saxophone and trumpet. In addition to their occupation as musicians, they have been engaged in farming as tenants.

\section{Pambada}

In South Kanara, Pambada have played significant roles as dancers as well as spirit mediums in büta rituals. Though they follow a matrilineal system and have matrilineal exogamous groups, their occupation and training as dancers is generally passed down from father to son. Among the three communities of būta dancers, i.e. Pambada, Parava, and Nalike, Pambada is ranked highest. In Perar, they perform the dance of, and also are possessed by, royal būtas called rājanu daiva. ${ }^{14}$

\section{Maddyele}

Maḍ̣̂ele are also called Maḍivāla. They follow a matrilineal system and have matrilineal exogamous groups. Traditionally, they have been engaged in washing. In Perar, their duty for the butas is to clean the sacred objects kept in the treasure house (bandārada kotya). Also, in the annual festival, they guard the sacred objects on the altar (kodiyadi) of the village büta shrine, and they assist with the performances of the Pambada dancers and Banța priest by holding torches. ${ }^{15}$ 
Next, I will provide a sketch of the land use in Perar and then examine the characteristics of büta worship, which is inseparably linked to the land and forests in this area.

\section{Land, forests, and deities}

Perar consists of lowlands and highlands, and there are significant differences in the nature of the soil, humidity, and vegetation of each type of land. The landscape of Perar varies greatly, from the lowlands, where one can see ears of rice waving in paddy fields and palm groves providing shade, to terraced paddy fields on hillsides, hilly deep forests, and dry highlands covered with shrubs and rocks.

The lowlands suitable for cultivating wet rice paddy are divided into bailu, majalu, and bottu. Among them, bailu is the lowest land. It is humid throughout the year and suitable for triple cropping. Bottu is higher than bailu and dry except for during the rainy season, and thus it is suitable for single cropping. Majalụ is located between bailụ and botțu, and is suitable for double cropping. Additionally, on the highest and driest land called kumeru, several kinds of vegetables suitable for arid land are cultivated (see Table 2.3). The cycle of triple cropping in bailu is as follows: first, in the month of beśa (from mid-May to mid-June), ${ }^{16}$ farmers plant rice seeds and wait for their growth. After 22 days, the seedlings are transplanted into rice paddies. After the rainy season, the first crop is harvested in the month of nirnäla. The seeds of the second crop are planted in the month of bontelu, the seedlings are transplanted into rice paddies in the month of jārude, and the crop is harvested from the month of perārde to puyintelu; while the seeds of the third crop are planted in the month of puyintelu, the seedlings are transplanted into rice paddies in the month of māyi, and the crop is harvested from the end of suggi to paggu (see Table 2.4). The crops planted in each season are called enelu, suggi, and kolake, respectively. Other food crops such as coconut palms, jackfruits, and mangos are cultivated around the houses. Since the 1980s, it has become prevalent among the villagers to cultivate areca palm as a commercial crop, and parts of the rice paddies have been converted to areca plantations.

Table 2.3 Land use in Perar

\begin{tabular}{|c|c|c|c|}
\hline Land name & Soil & Crop & Crop name \\
\hline bailụ & Most humid, lowland & Triple-cropping paddy & enelụ, suggi, kolake \\
\hline majalụ & Humid & Double-cropping paddy & enelụ, suggi \\
\hline botțu & $\begin{array}{l}\text { Dry except during the } \\
\text { rainy season }\end{array}$ & Single-cropping paddy & enelụ \\
\hline kumerụ & Driest, highland & Vegetables & - \\
\hline
\end{tabular}


Table 2.4 The crop calendar and yearly rituals in Perar

\begin{tabular}{|c|c|c|c|c|}
\hline & $\begin{array}{l}\text { Tulu calendar } \\
\text { (solar } \\
\text { calendar) }\end{array}$ & $\begin{array}{l}\text { Farming } \\
\text { activity }\end{array}$ & Ritual in Hindu temples & Ritual in būta shrines \\
\hline & $\begin{array}{l}\operatorname{paggu} \\
(4 / 15-5 / 14)\end{array}$ & $\begin{array}{l}\text { Harvesting } \\
\text { kolake }\end{array}$ & & $\begin{array}{l}\text { The ritual to take } \\
\text { down a pole } \\
\text { (kodimara) at the } \\
\text { village būta shrine }\end{array}$ \\
\hline \multirow{4}{*}{$\begin{array}{l}\text { Start of the } \\
\text { rainy } \\
\text { season }\end{array}$} & $\begin{array}{l}\text { beśa } \\
\quad(5 / 15-6 / 14)\end{array}$ & $\begin{array}{l}\text { Planting enelụ } \\
\text { seeds }\end{array}$ & & \\
\hline & $\begin{array}{l}\text { kārtelu } \\
\quad(6 / 15-7 / 14)\end{array}$ & $\begin{array}{l}\text { Replanting } \\
\text { enelụ in rice } \\
\text { paddies }\end{array}$ & & \\
\hline & àti $(7 / 15-8 / 14)$ & & $\begin{array}{l}\text { During the month } \\
\text { of àti, one should } \\
\text { not conduct any } \\
\text { auspicious rituals }\end{array}$ & $\begin{array}{l}\text { The ritual for Nāga } \\
\text { (nāgarapaṅcami) }\end{array}$ \\
\hline & $\begin{array}{l}\text { sōna } \\
\quad(8 / 15-9 / 14)\end{array}$ & & $\begin{array}{l}\text { sōna sainkrānti } \\
\text { The anniversary of } \\
\text { Krishna's birth } \\
\text { The anniversary of } \\
\text { Ganesha's birth }\end{array}$ & $\begin{array}{l}\text { Making offerings } \\
\text { to būta shrines } \\
\text { (cāvaḍ karipuni) }\end{array}$ \\
\hline \multirow[t]{4}{*}{$\begin{array}{l}\text { Start of the } \\
\text { winter } \\
\text { season }\end{array}$} & $\begin{array}{l}\text { nirnāla } \\
\quad(9 / 15-10 / 14)\end{array}$ & $\begin{array}{l}\text { Harvesting } \\
\text { enelụ }\end{array}$ & $\begin{array}{l}\text { Inauspicious day } \\
\quad \text { (mahālaya amāse)* } \\
\text { Rituals for nine } \\
\text { goddesses (navarātri) }\end{array}$ & \\
\hline & $\begin{array}{l}\text { bōintelu } \\
\quad(10 / 15-11 / 14)\end{array}$ & $\begin{array}{l}\text { Planting suggi } \\
\text { seeds }\end{array}$ & $\begin{array}{l}\text { Kaveri saíkrāinti } \\
\text { Lighting sacred lights at } \\
\text { temples }\end{array}$ & $\begin{array}{l}\text { Lighting sacred } \\
\text { lights at būta } \\
\text { shrines }\end{array}$ \\
\hline & $\begin{array}{l}\text { jārude } \\
\quad(11 / 15-12 / 14)\end{array}$ & $\begin{array}{l}\text { Replanting } \\
\text { suggi in rice } \\
\text { paddies }\end{array}$ & & $\begin{array}{l}\text { kambula } \\
\text { parva }\end{array}$ \\
\hline & $\begin{array}{l}\text { perārde } \\
\quad(12 / 15-1 / 14)\end{array}$ & $\begin{array}{l}\text { (Harvesting } \\
\text { suggi) }\end{array}$ & & \\
\hline \multirow[t]{3}{*}{$\begin{array}{l}\text { Start of the } \\
\text { dry } \\
\text { season }\end{array}$} & $\begin{array}{l}\text { puyintelu } \\
\quad(1 / 15-2 / 14)\end{array}$ & $\begin{array}{l}\text { Harvesting } \\
\text { suggi } \\
\text { Planting } \\
\text { kolake seeds }\end{array}$ & & \\
\hline & $\begin{array}{l}m \bar{a} y i \\
\quad(2 / 15-3 / 14)\end{array}$ & $\begin{array}{l}\text { Replanting } \\
\text { kolake in } \\
\text { rice paddies }\end{array}$ & $\begin{array}{l}\text { The anniversary of } \\
\text { Ishvara's birth }\end{array}$ & $\begin{array}{l}\text { The annual festival } \\
\text { (nēma) at the } \\
\text { village būta shrine }\end{array}$ \\
\hline & $\begin{array}{l}\text { suggi } \\
\quad(3 / 15-4 / 14)\end{array}$ & $\begin{array}{l}\text { Harvesting } \\
\text { kolake }\end{array}$ & & Other būta rituals \\
\hline
\end{tabular}

\footnotetext{
* In general, mahālaya means the offerings and obsequies made to ancestors during the second fortnight of the sixth lunar month. Also, mahālaya amāse indicates the new moon day of the mahālaya fortnight (Upadhyaya 1988-1997: 2549).
}

In addition to the paddy and other cultivated fields, the forests and hills called gudde are an important resource for the villagers' lives. People often go into the guḍde to hunt game or gather useful plants. Since most guḍe land is under the control of local manor houses, a villager who hunts game there shares part of his bag with the relevant manor house. The guḍe is 
believed to be the dwelling not only of wild animals but also of bütas and other spirits. In Perar, several Nāga (a serpent deity) shrines are located inside the groves, and a shrine to Pilicāmuṇdi (a tiger būta) is located on top of a hill near the village būta shrine. Because it is believed that various buttas of wild animals as well as other dangerous spirits are wandering about in the guḍde, it is regarded by most villagers as a fertile but hazardous place filled with śakti. As we will see next, in a ritual called the kambula, a priest goes into the guḍde alone and calls a būta down from the summit of a mountain.

\section{The kambula ritual and wild śakti}

In Perar, the main guttu houses devote some of their fields to the būtas. For instance, the Mundabețu guttu has paddy fields called bākimāru and kambula. ${ }^{17}$ These fields are regarded as the belongings of the deities, and most of their products are allocated to covering expenditures for the buta rituals. Among these rituals, one important ritual is held in the kambula field in the month of jārụde, just before the second crop is transplanted. The purpose of this ritual is to invite büta śakti from the forests into the agricultural field.

Here, I examine the battalu kānike kambula (henceforth kambula) ritual, which is dedicated to the būtas and organised by the Mundabeț̣u guttu. Below is a summary of the ritual based on the accounts of Subba of the Manșa caste, ${ }^{18}$ who was born in the early 1940s and has played an important role as a priest (kallāla) in this ritual. His role as a priest is limited to a few days during the kambula ritual, so he has been otherwise engaged in day labour, or just getting drunk and hanging around the village.

The day before the kambula, I [Subba] go to the kambula field [of the Mundabețtu guttu] in the morning. First, I put white mud on each of the coconut trees surrounding the field. This turns the kambula field into a bride (madumālu). Then I also put white mud on a stake (pükare) ${ }^{19}$ in the middle of the field. After that, I go back to the guttu house, where they give me two pieces of clothing. When it starts to get dark, I take a bath at home and then put on these clothes and go to a Pūjāri's house. There, I sleep until around midnight on a coconut leaf prepared by the head of the house. They used to prepare palm wine for me too, but nowadays it is only the leaf. When I wake up, I go to a place called Bolinji Mountain (Bolinji Guḍe $\varepsilon$ ). When I reach its summit, I climb onto a giant rock and call out to all the buttas, including the buffalo, ${ }^{20}$ to come to the kambula. I call out three times: 'kāṇikeda kambuḷa, buffalo, oh buffalo! (kāṇikeda kambula, eru vo eru)'.

Then I come down to a place called manjotti, just beside the kambula field, where my [male] family members are playing double-faced drums $(d \overline{o l u})$ while awaiting my arrival. ${ }^{21}$ We dance together and when we finish the dance I throw a stick $(k \bar{o} l u)$ on the ground, which I have carried to the mountain with me. Then we come back to the guttu house where they serve us rice and vegetable curry. 
On the day of the kambula, a pair of buffalo is taken into a buffalo house. After reciting a prayer, I tie a yoke (nuga) onto the necks of the buffalo, hold it, and run onto the kambula field along with the beasts. After that, we [Subba and his family members] go back to the guttu house and dance again in front of the guttu people. The next morning, I plant a handful of young rice plants (néji) in the kambula field, on the east side of the stake.

(Subba, 19 July 2008)

As seen in this narrative, in advance of the kambula ritual, the priest goes up the mountain and calls the buffalo büta. In the ritual, a living buffalo led by the priest kicks up mud and runs into the paddy field as a 'bride'. As the one who temporarily acquires wild śakti by coming and going between the guḍ $\varepsilon$ and the human world, the priest is the first person to plant the young rice plants and the first to harvest the ears of rice in the kambula field. The kambula ritual can thus be characterised as an agricultural rite, which links the agricultural fields to the guḍd $\varepsilon$, as well as the humans to the bütas, in that it involves invoking and encountering the fertile wild sakti from the forest. $^{22}$ This is considered an example of the transactional network (Appadurai \& Breckenridge 1976), which links the realm of humans to that of the wild through priests and mediums. We will consider this issue in more detail in Chapter 6.

\section{Büta worship and the granting of land}

In addition to the farmlands such as the kambula fields held by the guttu houses for būta rituals, there are particular plots of land called bākimārụ, which were originally the property of the village büta shrine. In the past, all ritual expenses and shrine worker rewards were paid in the form of paddy produced on this land, and villagers had a duty to take part in the agricultural work there. ${ }^{23}$ Although the bākimārụ had been managed by each successive head of the Mundabețtu guttu, most of the plots were acquired by tenants after the implementation of the land reform legislation in the $1970 \mathrm{~s}^{24}$

The families of the ritual servants (cākiridakulu) of the village būta shrine also had some plots of land. According to the oral epic, about 800 years ago, each cākiridakulu family was granted a portion of tax-free land called umbal $i^{25}$ from Koratāi Balardi, who was then the head of the Mundabetṭu guttu. Some settled on this land, and portions came to be named after their owners, for example, Pambaderع Kōdi (Pambada's Hilltop) or Jōgile Bailụ (Jōgi's Plain). Also, these cākiridakulu families enjoyed rights to shares of the paddy produced on the bākimārụ. Apart from the cākiridakulu families, in reward for their services and offerings to the büta shrine, other families of various castes such as Pūjāri, Ācāri, and Kuḍubi also enjoyed rights to shares of the farm products in the form of the prasāda (blessed offerings from the altar) distributed during the yearly ritual in the village shrine. 
In Perar, būta worship has thus formed the core of social and economic relations in the village through the (re)distribution of land, local products, and prasāda. Perar land and its products are primarily regarded by the villagers as the embodiment of the büta's power, and each family is granted rights to shares of plots of land, local products, and privileges in exchange for performing different services at the village büta shrine.

\section{The Näga as the earth goddess and the büta as the owner of the land}

Land in Perar is not only used for büta rituals, but also directly linked with the deities. In Perar, there are numerous small shrines in compounds or at the ends of agricultural fields. Some of these shrines are for the butas called jāgeda daiva (land būta), which are thought to dwell in the land. ${ }^{26}$ Since each jāgeda daiva is inseparably related to a particular plot of land, its power is thought to stay there even if ownership of the land changes. Therefore, new residents of the land must undertake the role of worshipping the jāgeda daiva. Otherwise, it is said that they will suffer the curse of the deity.

As seen in this chapter, land in Perar is inseparable from the butas, which are regarded as manifestations of the wild sakti filling the forests and fields. According to the oral epic, the boundary of Perar was determined by Balavāṇdi, the royal būta. Management rights and duties for particular plots of land in the village were also granted by the deities to the higher-ranked guttu families in exchange for worship. Therefore, the rights of the guttu houses to their land should be confirmed and performatively executed in the būta rituals. Since the ultimate 'owners' of the land are thought to be the deities, the people are merely permitted use of the land and enjoyment of its products.

In this sense, it is not appropriate to call these guttu families 'landowners' with exclusive rights on particular plots of land. Rather, they have a duty to arrange and control the process of the collection and redistribution of farm products in the village, and also to return part of these products to the deities through rituals. Similar to Balavāṇdi allowing the guttu families to use the land, Koratâi Balardi is said to have bestowed the land to the cākiridakulu families, allowing them to use the land in exchange for their services at the village buta shrine; she thus acted as a substitute for the royal būta. However, as we will see in Part Two, the land tenure system in Perar has gone through a complex process of continuance and transformation following the changes in the land tenure systems in South Kanara, such as the introduction of land-tax assessment and land reforms.

To conclude this chapter, I will now briefly outline the worship of Nāga as the 'earth goddess'. Nāgas are said to be the deities of the cobra, and there are numerous small shrines dedicated to them called năgabana in the forests near rivers and ponds. A Brahman priest living in the village performs a ritual every month for the Nāgas, and a special ritual called nāgarapañcami is performed in the month of $\bar{a} t i$. Unlike ordinary butta rituals, the ritual for 
the Nāgas adheres to the manners of a Brahmanistic ritual. In the nāgarapañcami, the Brahman priest chants a mantra, pours five kinds of liquids (i.e. milk, curd, gee, coconut juice, and honey) called pañcāmrta abhișēka onto the stone statue of Nāga, and offers a votive light.

Living cobras are also worshipped as incarnations of Nāgas. If a cobra appears in a particular place such as a būta shrine or the main hall of a guttu house, this appearance is interpreted as spiritual message or warning to the people related to that place. In that case, people often attempt to find the reason behind the arrival of the animal by means of astrology (aștamangala praśne). Also, if a person finds the dead body of a cobra, the person and his/her family must go into mourning for 16 days. As with the jāgeda daiva, Năga as the earth goddess raises the question of who is the real 'owner' of the land in Perar. We will consider this issue in more detail in Part Two.

In the next chapter, I will introduce the main deities or royal būtas enshrined in the village shrine and outline the roles of the guttu houses and ritual servants.

\section{Notes}

1 According to a document in the village panchayat in Padu Perar, the size of Mudu Perar is 896.24 hectares and that of Padu Perar is 829.3 hectares. Though there is a panchayat office in both Mudu Perar and Padu Perar, only the one in Padu Perar functions as an administrative office.

2 Though Mudu Perar and Padu Perar were administratively separated, they still function as subdivisions of the larger erstwhile village of Perar, which is considered the basic unit for the villagers. Therefore, I will also refer to Perar as a 'village' in this book.

3 In general, guttu refers to the manor houses, or the families responsible for organising the rituals in a village (Upadhyaya 1988-1997, p. 1109). As we will see later, there are 16 houses in Perar called the 'sixteen guttus', and they play important roles in the būta worship at the village level. Also, as we will see in Part Two, in the Vijayanagara period, a guttu was one of the units of administration and land-tax collection in South Kanara.

4 According to the same document, as of 2001, in Mudu Perar, 66 people (34 males and 32 females) belong to the Scheduled Castes (SC) and 15 people ( 8 males and 7 females) belong to the Scheduled Tribes (ST). In Padu Perar, 142 people (74 males and 68 females) are SC and 46 people ( 22 males and 24 females) are ST.

5 Tables 2.1 and 2.2 were made by the author based on the house-tax record (Padu Perar Panchayat Office 2008) kept in the village panchayat office in Padu Perar.

6 In Guru Kambula, there is a mosque and the mausoleum of a saint, and this area's land was the property of the mosque before the implementation of the land reform legislation in 1974. On the hilly area in the northeast of Mudu Perar, there is a St Francisco Xavier church.

7 Though most Banțas are landlords in South Kanara, they are categorised as $\mathrm{OBC}$ because most of them living in the rural area are engaged in agriculture.

8 They are also called Bunts in English. Bantereru means the warrior or servant of a king, and Okkelakulu means agriculturist. See also Thurston (1975[1909a], pp. 147-172).

9 For additional general information on Kuḍubi, see Thurston (1975[1909b], pp. 99-106). 
10 For additional general information on Pūjāri (Billava), see Thurston (1975[1909a], pp. 243-252).

11 For additional general information on Ācāri, see Thurston (1975[1909a], p. 61).

12 In this book, I use 'Brahman' instead of 'Bațturụ' in line with the relative popularity and distinctiveness of each term.

13 According to Thurston (1975[1909a], p. 375), 'Ahi-Kshētra' is probably a Sanskritisation of 'Haiga', or 'the land of snakes'.

14 For more general information on Pambada, see Singh (2002[1993], pp. 1028-1031) and Thurston (1975[1909d], p. 206).

15 For more general information on Maddyele, see Thurston (1975[1909a], p. 16-18).

16 On the correspondence between the Tulu calendar and the solar calendar, see Table 2.4.

17 In general, bākimārụ indicates a field in front of a house. Also, kambuḷa refers to a buffalo race held in a paddy field or river canal, to a field in which this buffalo race takes place, and to a ritual performed in a rice field for fertility (Upadhyaya 1988-1997, pp. 592, 2273). In addition to the kambula, a ritual called the parva is held in the main hall of the Mundabetțu guttu's house. In general, parva denotes the auspicious day on which festivals and rituals are held. See Upadhyaya (1988-1997, p. 1958).

18 Subba himself insists that he is an 'Ádi Dravida (original Dravidian)'.

19 Pūkare is an ornamental post decorated with flowers set in some selected paddy fields before specific rituals and buffalo races to ward off evil spirits. See Upadhyaya (1988-1997, p. 2087).

20 According to local legend, in antiquity a person and two buffalo disappeared on the mountain. The buffalo called by Subba here are supposed to be the butas of those missing buffalo.

21 In the past, on the next day of the kambula, Subba and his family used to visit each house of the village dancing and playing instruments. Nowadays they dance and sing only at the guttu house.

22 According to the villagers, a ritual called paniku kulluni was also performed during the kambula ritual. In this ritual, while waiting for the kallāla, the male relatives of the kallāla drank palm wine, had sexual intercourse with each other, and danced together. This suggests that male sexual vitality was important in the kambula ritual, which aimed to enhance the fertility and productivity of the agricultural field as a 'bride'. For a general explanation of panikụ kulluni, see Upadhyaya (1988-1997, p. 1923).

23 Nowadays, shrine worker rewards are paid in cash.

24 Most plots of the land in the name of the village shrine were purchased in the past by the heads of the Mundabetțu guttu. In Part Two, I will investigate the impact of the land reforms in more detail.

25 In general, umbali refers to rent-free land for the performance of certain services in temples or other public services (Upadhyaya 1988-1997, p. 342).

26 In addition to these jāgeda daiva, būtas worshipped by the members of a house called 'mane daiva (house būta)', and būtas worshipped by the members of a joint family called kuțmada daiva (family büta) are enshrined in these small shrines. 


\section{The büta shrine and deities in Perar}

Driving from Mudu Perar to Padu Perar, one finds on the right side of the main road a big gate with an inscription in Kannaḍa: 'Sri Brammadēvarụ Iśtadēvate Balavāṇ̣̣i Pilicāmuṇụi Daivastāna Kinnimajālụ Perar.' ${ }^{1}$ Three figures sit atop the gate. The left figure is carrying a sword and riding a tiger; the middle figure is holding a long sword and riding an elephant; and the right figure has a moustache and is holding a bow and arrow and riding a horse. This gate is the entrance to the road to the village buta shrine, and the three figures are modelled on the main deities: Pilicāmuṇụi, Arasu, and Balavāṇ̣ii.

Going through the gate and down the winding road, one sees a red-tileroofed building surrounded by coconut trees and paddy fields. In the middle of the site, there is a small shrine decorated with flowers. This holy place, called Banțakamba, is where Balavāṇdi, the main deity in Perar, is believed to have appeared. ${ }^{2}$ During the yearly ritual (nēma), priests and devotees carry sacred objects from the treasure house (baṇdāada koṭya) to Baṇtakamiba. The mukkāldi, the priest-medium of Balavāṇdi, is then possessed by the deity in front of the small shrine and gives an oracle to the heads of the guttus. As we will see in Chapter 5, on the last day of the nema, the ritual of the būta's judgement (vāku piripuni) is held in this place.

Walking south from Bantakamba on the footpath between the paddy fields, one comes to a large gate painted vermillion and cobalt blue. Beyond the gate, there is a courtyard with several buildings roofed with mossy red tiles, and it is surrounded by a cloister. This is the village bu ta shrine (daivastāna), the base of būta worship in Perar. Enshrined here are Balavāṇdi, Arasu, Pilicāmuṇ̣̣i, and the highest-ranked deity, called Bramma. In this chapter, I will outline the būta worship in this village shrine. First, I will sketch the structure of the shrine and Bantakamba. Next, I will briefly describe the characteristics of the main deities in the shrine. Finally, I will discuss the people and families who undertake religious roles.

\section{The village shrine in Perar}

Most of the important buildings concerning būta worship are located in the easternmost part of Padu Perar, near the border of Mudu Perar. The most important places are the village būta shrine, Banțakamba, and the treasure 
house. The shrine is the centre of büta worship in Perar; Bantakamba is the birthplace of Balavāndii; and the treasure house is the place in which the sacred objects for the būta ritual are kept. The three places form a roughly equilateral triangle, as they are each approximately 100 meters apart. During the nēma in the village shrine, the priests, heads of the guttus, musicians, and other ritual workers march the sacred objects from the treasure house to Banțakamba. After offering a votive light to the small shrine, they march to the village shrine to conduct the main rituals. The land circumscribed by these three places is a double-cropping paddy field called majalụ. During the nēma, which is held after the cultivation of the second crop in the month of māyi, one finds a row of many stools on this field. Behind Bantakamba and the treasure house, there is a verdant coconut grove, and behind the village shrine, there is a hill, on top of which Pilicāmuṇụi is enshrined.

Daivastāna consists of several buildings on a spacious ground surrounded by a cloister. ${ }^{3}$ Passing through the main entrance from the east and entering the precincts, one can see in the foreground a two-storey shrine for Bramma called Bramma guṇa. A rule in the oral epic prohibits two-storey structures in Perar except for this Bramma shrine and the house of the Pejattāya. Unlike the rather simple structure of the būta shrines popular in this area, the Bramma shrine is ornately structured. It has stone steps and a stone lantern, is equipped with an offertory box and a bulletin board, and is always decorated with flowers and votive lights. The exterior of the Bramma shrine is just like that of a Hindu temple. Looking into the shrine from its opening, one can see through the dark a statue of the brammalinga on a stone pedestal lit by votive lights. The statue is surrounded by a golden halo called a prabāvali.

A Brahman priest called an asrāṇna is stationed at the Bramma shrine and conducts the daily ritual. He purifies the brammalinga and other statues with water, makes an offering of jasmine flowers and betel leaves (baccirc: Piper betle), and then offers a votive light while chanting a mantra. South of the Bramma shrine, there is a tower with a mossy peaked roof. This building is called a $m \bar{a} d a$, a shrine for Arasu. A steep staircase links the ground to the opening on top of the building. The asrānna climbs these stairs to offer a votive light and descends them facing the opening in order not to turn his back on Arasu. To the east of the māda, there is an altar called a koḍiyadi. Though usually there is no object on the altar, during the nēma, it is beautifully decorated with lights and flowers, and the sacred objects brought from the treasure house are placed on it. South of the māda and koḍiyaḍi, there is a building with windows and an entrance facing the north. This is called the mūverullākule cāvadi (hall for the three kings), and there are wooden altars (man்cāvu: bed) for Balavāṇḍi, Arasu, and Pilicāmuṇdi inside the building. ${ }^{4}$

Passing through the west gate and walking out, one finds a pond of green water and a Nāga shrine under a big tree. This enshrines the stone statue of the snake goddess - her lower half is a snake and nine snakes raise their heads from her head like a halo. South of the village būta shrine, there is 
a relatively high hill. At the foot of the hill, there is an entrance for the long approach to the Pilicāmuṇụi shrine. During the nēma, the priests, the heads of the guttus, and the musicians ascend the narrow stone steps to the summit, offer votive lights at the Pilicāmuṇụi shrine, and then return to the precincts of the main shrine. Since most rituals are performed at night, one can see from the shrine precincts the flickering light carried by the asrānna moving in the woods, accompanied by the faint sound of wind instruments.

\section{The three būtas and the ambiguous deity Bramma}

As already mentioned, Balavāṇ̦i, Arasu, Pilicāmuṇ̦i, and Bramma are the main deities enshrined in the village būta shrine in Perar. The first three are regarded as the royal būtas (räjanụ daiva) and are together called the three lords $\left(u l l a \bar{a} k l u^{5}\right)$. Meanwhile, Bramma or Bermerụ, who is often identified with the Hindu god Brahma and is related to the earth goddess Nāga, occupies an ambiguous position in büta worship. I will briefly overview the characteristics of each deity below.

\section{Balavandi, the deity that appeared in the land of Perar}

Balavāṇ̣i occupies the central position in būta worship in Perar. As we will see in detail in the next chapter, Balavāṇ̦i was believed to have appeared from Bantakamba, and also to have taken Arasu and Bramma to this land. While other būtas such as Arasu and Pilicāmuṇ̦i are enshrined throughout South Kanara, Balavāṇḍi has only the shrine in Perar. Balavāṇụi is therefore regarded as the unique and principal deity in the village shrine. Although Balavanṇi is often described as a brave fighter with a moustache and bow and arrow, the deity is regarded as androgynous. As we will see in Chapter 5, Balavāṇ ịi-incarnated in a Pambada dancer-medium - first dances wearing a luxurious skirt, and then changes garments, dons a moustache, takes up a bow and arrow, and challenges Bramma to a fight.

\section{The king of bütas, Arasu}

The būta called Arasu is also called uḷāklụ. In the oral epic, Arasu is described as the king of būtas and is served by many followers. Arasu is of a higher rank than Balavāṇ̣̣i and Pilicāmuṇụi, and thus when these three deities are depicted in art, he is placed at the centre. In the nemma also, the ritual for Arasu is conducted first, before the rituals for the other two deities. The high position of Arasu, however, does not necessarily entail the centrality of the deity in the village būta shrine. Though Arasu holds a higher position than Balavāṇdi, it is Balavāṇ̣̣i who occupies the central role in both the oral epic and the nēma in Perar. Most devotees regard the village būta shrine as the 'Balavāṇ̣̣i shrine'. 


\section{The büta of the wild tiger, Pilicāmunḍ}

In paintings and statues, Pilicāmuṇụi is always described as a figure riding on a tiger, as this deity is regarded as the būta of the wild tiger. This gives rise to some unique features in the worship of Pilicāmuṇ̣i in the village būta shrine. For instance, while other deities are enshrined in the main shrine, Pilicāmuṇịi is enshrined in a small hilltop shrine. In addition, unlike Balavāṇdi and Arasu, who are believed to be vegetarians, Pilicāmundịi is believed to be meat-eating. During the nēma, only vegetables such as paddy, bananas, and coconuts are offered to Balavāṇdi and Arasu inside the precincts of the main shrine; meanwhile, live fowl are offered to Pilicāmuṇ̦i outside the precinct. Pilicāmuṇ̣i, however, is not always in a marginal position. As we will see in Chapter 5, on the last day of the nēma, there is a prolonged ritual especially for Pilicāmuṇdi. In addition, the ritual called vākụ piripuni, in which devotees consult the deities about their problems and receive oracles, is held at Banțakamba. In this ritual, it is Pilicāmuṇụi incarnated in a Pambada dancer-medium and Balavāṇ̣i incarnated in the mukkāldi who give judgements on the various problems of the people. Thus, while Pilicāmuṇ̦i is in a rather marginal position in the village butta shrine, the deity plays the important role of giving oracles and blessings to the devotees in the last ritual of the nemma.

As seen above, Balavanndi, who originated in the area, occupies the central position in the village büta shrine. In terms of the rank of the deities, however, Arasu is dominant in the shrine as the 'king'. Meanwhile, Pilicāmuṇ̦i takes on the important role of judge in the nēma. As we will see next, over these three deities, it is actually Bramma who occupies the highest position and plays another important role in the village büta shrine.

\section{The ambiguous deity Bramma}

Bramma, also called Bermeru, occupies a special position in the village būta shrine. Bramma is regarded as the highest-ranked būta who governs the other butas; at the same time, the deity is often identified with the Hindu god Brahma. ${ }^{6}$ As already seen, in the village büta shrine, only Bramma is enshrined in a temple-like guṇạ. In addition, a Brahman priest called an asrānna is stationed at the shrine to conduct a daily ritual. Unlike other būtas, who manifest themselves through spirit possession, Bramma never manifests himself except in the figure of the brammalinga. Nevertheless, in both the daily rituals and the nēma, the Bramma shrine is very important; it is carefully attended to by the asrānnna, and devotees always first visit the Bramma shrine and receive prasāda from the hands of the asrānna before they visit the other places in the precincts. In the nēma, the Bramma shrine becomes the central stage of the rituals. As we will see in Chapter 5, the main actors such as the priests, heads of the guttus, and other ritual workers march around the Bramma shrine and koḍiyadi many times. In addition, the Pambada dancer-medium possessed by Balavanṇdi dances in front of the guṇua to challenge Bramma to a fight. 
As shown in the role of the asrānnna, since Bramma has the ambiguous characteristics of both a büta and a Hindu god, some elements of the Brahmanical ritual are contained in the village būta shrine. At first glance, this seems like an example of Sanskritisation: an indigenous ritual of lower-caste people transforms itself by adopting and imitating Brahmanical rituals (Srinivas 1952, pp. 30-31). ${ }^{7}$ In the case of the village būta shrine in Perar, however, the existence of the asrānnna and the Brahmanical ritual indicates other intricate issues that cannot be interpreted merely as an example of Sanskritisation. While the attendance of Brahmans such as the asrānna and Pejattāya is indispensable to the būta ritual today, some villagers remain ambivalent about the entry of Brahmans into būta worship, which had originally been conducted by non-Brahmans such as Banța and Pūjāri. Meanwhile, the Brahman priests concerned in būta worship in the village do not just apply Brahmanical rituals to the bütas, but also learn the ritual practices unique to each būta. This suggests that būta worship has not been simply Sanskritised, but rather brings the Brahman priests into it.

Moreover, while Bramma is often identified with the Hindu god Brahma, the deity is also closely related to the earth goddess Nāga. The ambiguous identity of Bramma has been one of the most controversial issues in the disputes concerning authority over the village büta shrine. As we will see in Chapter 8 , in the court case between the asrānna and the first guttu family in the 1930s, the point of dispute became whether the Bramma gunda was a büta shrine or a Hindu temple, and whether the principal deity in the village shrine was Balavāṇdi or Bramma. ${ }^{8}$

\section{The people responsible for būta worship}

The būta ritual in Perar is based on a sophisticated system called kattụ (custom or law), which governs the people in the village. Below, I will provide an overview of the main ritual roles and the people responsible for the rituals in the village būta shrine.

Each guttu family has specific duties in the būta rituals and management of the village būta shrine. The role of each guttu at the shrine is inherited within the respective family. As shown in Table 3.1, the prominent families in the village in relation to the butta ritual comprise a Brahman family called the Pejattayya and the 16 guttus. Except for one Kuḍubi family and three Pūjāri families, the other 12 families are Banta. ${ }^{9}$ These guttus are hierarchically ordered from the Mundabețu guttu at the top to the Pērīrụ guttu at the bottom. Each guttu family has various roles and duties in organising rituals at the village shrine. The first and second guttus have primary responsibility for the patronage and management of büta worship at the village level. ${ }^{10}$

The roles of the 16 guttus are complemented by another 16 families called the ulaguttu (sub-guttus). Under these guttu and ulaguttu families, dozens of people called cākiridakulu (servants/people in service) render various services 
Table 3.1 The prominent families in Perar in relation to būta worship

\begin{tabular}{|c|c|c|c|c|}
\hline General name & Status & Name of the family & Caste & $\begin{array}{l}\text { System of } \\
\text { inheritance }\end{array}$ \\
\hline Pejattāya & Highest & Pejattāya & Brahman & Patrilineal \\
\hline Sixteen guttus & $\begin{array}{r}1 \\
2 \\
3 \\
4 \\
5 \\
6 \\
7 \\
8 \\
9 \\
10 \\
11 \\
12 \\
13 \\
14 \\
15 \\
16\end{array}$ & $\begin{array}{l}\text { Muñḍabetțu guttu } \\
\text { Brāṇabeț̣u guttu } \\
\text { Tidyamundoțț̣ guttu } \\
\text { Pāldaḍi guttu } \\
\text { Alake guttu } \\
\text { Kolakebailụ } \\
\text { Parāri } \\
\text { Gōldadi } \\
\text { Mairōḍi } \\
\text { Naḍi } \\
\text { Boțtottu } \\
\text { Uliya } \\
\text { Śāstāvu } \\
\text { Kabetti } \\
\text { Tanya } \\
\text { Pērīrụ }\end{array}$ & 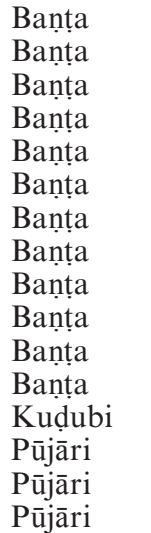 & $\begin{array}{l}\text { Matrilineal } \\
\text { Matrilineal } \\
\text { Matrilineal } \\
\text { Matrilineal } \\
\text { Matrilineal } \\
\text { Matrilineal } \\
\text { Matrilineal } \\
\text { Matrilineal } \\
\text { Matrilineal } \\
\text { Matrilineal } \\
\text { Matrilineal } \\
\text { Matrilineal } \\
\text { Patrilineal } \\
\text { Matrilineal } \\
\text { Matrilineal } \\
\text { Matrilineal }\end{array}$ \\
\hline
\end{tabular}

for būta worship. These people are from particular families who belong to several service castes in the village, for example, Maḍdyele (washermen), Purușa or Jōgi (musicians), Baṇ̣̂āri (barbers), and Pambada (dancers).

While the Pejattayya occupies the highest position in the ritual hierarchy in the būta shrine, it is actually the Mundạabțtu guttu, represented ritually by the gadipatinārụ, who has assumed control of the shrine's management as well as the ritual practices. The priests (mukkāldi) for Balavāṇ̣i and Pilicāmuṇ̦i are selected from the male members of the Alake guttu and the Uliya guttu, respectively.

The social ranking of these main families and castes in the village corresponds to their hierarchical order in the būta ritual. In Perar, the people who often compete with each other for ritual status are not those who belong to different caste groups, but are instead guttu families of the same caste. The hierarchy of the guttu families, which is based on the oral epic, is performatively confirmed and dramatically publicised in the nēma: the main deities incarnated in the Pambada dancer-mediums dance around the heads of the guttus and call the names of the families in order of their rank. Next, I will outline the main ritual roles in the village büta shrine.

\section{The gadipatināru}

The primary patron of the village shrine is the Mundabețtu guttu head called the gadipatinārụ, and this person has command over all other guttu members and ritual workers. The present gaḍipatinārụ is Gangādara Rai, born in 1931. A tall figure in a white cloth and turban, sunglasses on his chiselled 
face, he possesses an air of dignity and elegance. After his elder brother, the previous gadipatinārụ, died in 1999, he took over the role in 2001. To select the next gadipatināru, first a candidate is chosen by the core members of the Munịabețtu guttu family. Then they consult Balavāṇdi about their selection through a ritual. If acknowledged by the deity, the person can then be appointed the gadipatinārụ; if not, the family selects another person. The term 'gadipatinārụ' originally indicates the person who takes authority/responsibility (gadi), and this duty must be fulfilled to one's dying days. Moreover, one must obey various rules and taboos. Since the gaḍipatinārụ contacts the deities and mediates the relationship between the people and deities, he should always keep himself pure and clean. Therefore, it is taboo for him to eat and drink outside, or to touch or even see a person regarded as being ritually polluted by death, childbirth, or menstruation.

In the village būta shrine, the gadipatinārụ plays a significant role both in shrine management and in ritual practice. Supported by the madyaste, the head of the second guttu, the gadipatināru is in charge of the management of the shrine's property and of other administrative work concerning the būta ritual. Moreover, he is responsible for dealing with the būtas and their śakti. While the Pambada dancer-mediums embody būtas in the ritual, the gaḍipatināru plays the role of their most intimate caretaker. In every būta ritual at the shrine, the gadipatināru responds to every word and action of the deity, appeases the deity's anger, and speaks to the deity on behalf of the other devotees. Gangādara Rai refers to his intimate relationship with the būtas as follows:

Only the gadipatinārụ can physically touch the deity_nobody else can do it. Only the gadipatinārụ can assuage the deity's thirst. ${ }^{11}$ The gadiipatinārụ has adikāra to the deity and also the deity has adikāra to the gadipatinārụ. To hand a sword to the deity and receive it from her is the adikāra of the gaḍipatinārụ.

(2 July 2008)

As this narrative indicates, people often mention adikāra in relation to the relationship between humans and deities. Adikāra originates from the Sanskrit word adhikāra, which means authority, royalty, rank, and right (Monier-Williams 2008 [1899], p. 20). In Tulu, this word has a broader meaning, including authority, power, rank, office, administration, governing, and responsibility (Upadhyaya 1988-1997, p. 96). In the context of būta worship, adikāra describes the mutual rights and responsibilities of humans and būtas. It also indicates the privilege of the caretakers who have the right and responsibility to maintain an intimate relationship with the deities.

The gaḍipatinārụ is responsible not only for the būta ritual in the village shrine but also for all the butta rituals performed in Perar. He is expected to attend every ritual (kola), and if he cannot, a male member of the Munịabețu guttu should attend it on his behalf. The duty of the gaḍipatinārụ is thus held 
by the Mundabețtu guttu as a whole. This is also shown by the fact that the title of the gaḍipatinārụ is primarily passed down from mother's brother to sister's son.

\section{The mukkāldi}

In many parts of South Kanara, the roles of the būta priests, called māni or pātri, are played by Pūjāri. Although there are several mānis in Perar, Banța priests called mukkāldi mainly conduct the rituals for the rājanụ daivas, or royal būtas, in the village büta shrine. The present mukkāldi of Balavāṇụi is Bālākrishna Shetty, who was born in 1972 and belongs to the Alake guttu family. With thick black eyebrows, moustache, and penetrating eyes, Bālākrishna is a person of imposing presence. Despite his rather young age, he occupies the leading position among the heads of the guttus in Perar. He has a profound knowledge of the rituals and customs concerning the oral epic, history, and būta worship.

In 2005, Bālākrishna succeeded the title mukkāldi from his mother's brother. Similar to the case of the gadipatinārụ, the mukkāldi title is hereditarily succeeded within the kuțuma (matrilineal joint family). After he was selected as the mukkāldi, Bālākrishna was purified by the asrāṇṇa in a ritual called kalaśasnāna. In this ritual, the asrāṇna pours kalaśanīru (sacred water in a pot) on a person who will render a sacred duty. ${ }^{12}$

As we will see in the next section, the mukkāldi and Pambada dancer-mediums have several similarities in terms of their roles in büta worship. Nevertheless, they are regarded as profoundly different in the ritual system in the village butta shrine. One of the differences between them is the mode and frequency of their possession by deities. In the case of the Pambada dancer-mediums, they are possessed by the rājanụ daivas only in the nēma. ${ }^{13}$ Meanwhile, the mukkāldi is responsible for every būta ritual performed in the village from the sọna month to paggu month, and during this period, the deity frequently possesses him. Bālākrishna explains this as follows:

The work of the Pambada is to dance with makeup and a costume in the nēma. But the mukkāldi invokes daiva even in his plain dress. The Pambada cannot enter the inside of the shrine. It is the mukkāldi who conducts the rituals inside the shrine. From the month of sōna to the beginning of the month of paggu, the mukkāldi does so much work. For instance, sōṇa san̉krānti, parva, Māri pūjā, kambuḷa ... it is the adikāra for the mukkāldi to conduct these rituals.

(2 July 2008)

Throughout the nēma, the mukkāldi continuously engages in the ritual. As the priest as well as the medium of Balavāṇdi, he swiftly transitions between states of being possessed and self-possession, and he occasionally manifests 
physical power beyond his ordinary strength. He cannot control the overwhelming force of spirit possession.

Balavāndi daiva is different from other deities. She follows her own wishes and desires. It is not necessary to dance and play music [to invoke her]. She can come anytime. Throughout the ritual, she remains in my body. Even when I'm just staying at home, she can come into me.

(Bālākrishna Shetty, 2 July 2008)

As we will see in Chapter 5, the mukkāldi possessed by Balavāṇ̣̣i marches around the shrine precincts many times, offers votive lights at the altar, and recites oracles. Even when in his normal state, he cannot rest. As one of the heads of the guttus and the assistant to the gaḍipatinārụ, Bālākrishna must carefully organise the whole ritual process. In addition, in the more smallscale rituals held in each guttu house, the mukkāldi plays an important role. Embodying the principal deity, Balavāṇdi, he states oracles, gives various orders to people, and finally blesses them. The figure of Balavāṇụi incarnated in the mukkāldi is always filled with overwhelming power and anger, which arouses awe in others.

Both in rituals and in daily life, the mukkāldi, who belongs to a highranked guttu family and holds an influential position in the village, exercises an authority that exceeds that of other ritual workers, including the Pambada dancer-mediums. As we will see in Chapter 8, the authority and predominance of the mukkāldi influences disputes and negotiation among people concerning būta worship.

\section{Pambada dancer-mediums}

In addition to the mukkāldi, the Pambada dancer-mediums play a vital role in the village būta shrine. While the mukkāldi works as the priest, the Pambadas are unique in their ability to impersonate bütas, to dance, and to recite păḍdana. In South Kanara, those who belong to the Pambada, Parava, and Nalike are engaged in büta worship as dancer-mediums. In relation to būta worship, these three groups are hierarchically distinguished from each other: the Pambada dancer-mediums mainly perform the higher-ranked būtas called rājanụ daiva, and the Nalike dancer-mediums perform the lower-ranked būtas. ${ }^{14}$ While most būtas performed by Pambadas are enshrined in the main būta shrine in the village, most būtas performed by Nalikes, such as Satyadēvate, Kallurți, and Mantradēvate, are enshrined in small household shrines and altars. Regarded as inferior to the rājanụ daiva, they are often called kātu büta, or the wild, untamed būta. For most villagers, the kātụ būtas are more familiar than the rājanụ daiva enshrined in the village būta shrine. Since there are no Nalike in Perar, Nalike dancermediums are called from other villages to perform the rituals for these butas. 
In Perar, the male members of a Pambada family living in the village render services to the village būta shrine as dancer-mediums. Though Pambadas are generally matrilineal, the profession of dancer-medium is hereditarily succeeded from father to son; close relationships and collaboration among paternal kin are also necessary to their performance. Among the Pambadas in Perar, two youths - Jayānanda and his second cousin Yatish Pambadaplay central roles as the dancer-mediums of the three main būtas: Balavāndị, Arasu, and Pilicāmuṇ̦i. In addition to their roles in the village būta shrine, they perform at several small shrines in Perar. The areas each is responsible for is decided by the rājanụ daiva that each performs: Yatish, who performs Balavāṇdi, has the right to dance in Mudu Perar; while Jayānanda, who performs Arasu and Pilicāmuṇdi, has the right to dance in Padu Perar. Each should not encroach on the other's domain, as this may cause tension and trouble between them.

Yatish, born in 1974, lives with his mother, wife, and children in a house near the village būta shrine. He devotes himself to his duties as būta dancer-medium and wears a white cloth and small gold earrings that symbolise his profession. He is a cheerful and modest person who maintains good relations with the other villagers, including the guttu heads. As we will see in Chapter 5, as the dancer-medium of Balavāṇ̣i, Yatish plays the most important role in the nēma, which becomes a focal point.

According to Yatish, when one is appointed as dancer-medium of the rājanu daiva, the purification ritual is performed at the Bramma gunda; one then receives a gold bracelet from the gaḍipatinārụ. Similar to the gadipatinārụ and mukkāldi, the dancer-medium must fulfil his duty until he is on his deathbed. Whatever the reason, he is never allowed to cancel a būta ritual that he is supposed to attend.

The other main dancer, Jayānanda, was born in 1975. As the dancermedium of both Arasu and Pilicāmuṇ̦i, he performs on the first and last day of the nēma. On the last day, in the long ritual that continues for more than ten hours, he dances, recites păḍdana, speaks oracles, and judges people's problems as Pilicāmuṇụi. Jayānanda is intelligent and gentle-mannered and has deep knowledge of būta rituals. His pride and principles distinguish him as a prominent dancer, but at the same time, they often cause him trouble with others concerning būta worship. As we will see in Chapter 8, Jayānanda is dissatisfied with the ways the nēma has been organised by the higher-ranked guttus. Taking the side of an influential person from outside the village claiming to promote the democratisation of the butta worship, Jayānanda has incurred the displeasure of the guttus.

Yatish and Jayānanda, through their performance involving spirit possession as dancer-mediums, manifest the wild sakti of the deities in the ritual. I will closely examine the experience of these dancer-mediums in Chapter 7.

As seen above, būta worship in Perar is based on a hierarchical system authorised by the kattu that consists of the 16 guttus, the priests, and the other 
ritual workers. Among them, the Mundabețtu guttu occupies the most influential position, as local manor as well as the main organiser of the village būta shrine. The role of the highest guttu in büta worship corresponds to that of kings and chiefs in relation to Hindu deities (e.g. Dirks 1987, p. 304, 1992, p. 225). In the Hindu temple, the king and other devotees mediated by priests present offerings to gods, and in return they enjoy the distribution of honours accompanied by various rights (Appadurai \& Breckenridge 1976; Appadurai 1981, pp. 20-37). Similar to this, the guttu families and other ritual workers enjoy various rights in return for their contribution to the būta shrine. The rights and duties of the people concerning būta worship, which the word adikāra indicates, are distributed to them through ritual transaction with the būtas.

Here, it is noteworthy that the rights and duties are never given to the devotees automatically, but rather they should be re-approved by the deities each time. Although customary law dictates that each family should execute its adikāra, there remains an essential uncertainty, since whether families can really assume their adikāra or not depends on the approval of the būtas within the ritual. Even the guttu families cannot maintain their authority without being acknowledged by the deities. In this sense, būta śakti, which is fundamentally contingent and uncontrollable, is superior to the mundane power of the guttus.

In the next chapter, I will examine the pạddana, which is one of the bases of the relationship between the villagers and the deities in Perar.

\section{Notes}

1 This is the formal name of the village būta shrine. Brammadēvarụ and Iśtadēvate are alternate names of Bramma and Arasu, respectively. Kinnimajālụ is the general name of the place consisting of Banțakamba, village būta shrine, and treasure house.

2 Kinnimajālụ and the village būta shrine are collectively called Kinnimajālụ sāna.

3 Though it is believed that the village büta shrine has an 800 -year history, these buildings were rebuilt in 1965. As we will see in Chapter 8, since 2013, the shrine has again undergone a controversial process of rebuilding.

4 There are altars for būtas in the houses of the higher-ranked guttus, and a Brahman priest living in the village performs rituals such as the sainkränti at these altars.

5 Uḷạklụ is the honorific title of a person of high rank. See Upadhyaya (1988-1997, p. 410).

6 Bramma's identity and origin are controversial issues among folklorists. See Padmanabha (1976, pp. 24-39), Upadhyaya (1996, p. 202), and Claus (1978).

7 Srinivas (1952) first described the concept of Sanskritisation as the adaptation of Brahmanical rituals, beliefs, and ways of life through which low castes seek to improve their position in the caste hierarchy. For this Sanskritisation, the coupled notions of purity and impurity are important as they systematise and maintain the structural distance between different castes.

8 It is believed that one rank below Balavāṇḍi, Arasu, and Pilicāmuṇụi, there are five more būtas; moreover, under these five būtas, there are another seven būtas. 
This is expressed as 'one Bramma, three uḷāklụ, five kāranīkeru (those who can do anything), and seven māyagarlu (those who are intangible)'.

9 Geographically speaking, these guttu families are selected in order from Mudu Perar and Padu Perar.

10 Among the 16 guttus, the top five families have maintained close relationships through marriage.

11 In the nēma, Balavāṇụi incarnated by the mukkāldi receives a coconut from the gadipatināru and pours its water on the ground.

12 This ritual is generally called kalaśaśuddhi (Upadhyaya 1988-1997, pp. 715, 716). Pambada dancer-mediums also receive this ritual purification every year.

13 Though the Pambadas are possessed by the royal būtas in the village büta shrine only in the nēma, they act as the dancer-mediums of other būtas in several other rituals both inside and outside Perar.

14 It is generally regarded that Paravas occupy the rank between Pambada and Nalike. 


\section{Päddana}

\section{The oral epics of deities}

The traditional relationship between the būtas and the main families in Perar, such as the Mundababtțu guttu and the Pejattāya, is described in an oral epic called the pạddana. The pāḍdana narrates not only the origins of the butas, but also their original relationship with the people who serve them. As we will see in Chapter 5, the dancer-mediums of Arasu, Balavāṇụi, and Pilicāmuṇ̣i sing the pạddana in the nēma. In front of the heads of the guttus and hundreds of spectators, the dancer-medium embodying the royal būta sings about mythological events such as battles and amicable settlements among būtas, and about interactions between būtas and humans. It is the păddana that most villagers refer to as the history of Perar. In this chapter, I will introduce the main oral epics in Perar, beginning with the pāḍdana of Nādu, who is an earlier avatar of Balavāṇụi. ${ }^{1}$

\section{The life of Nādu}

\section{The birth of Nādu}

Once upon a time, when Mangaluru was called Mangāra, the land was ruled by a king called Chandrashekara. In the place called Gurupura in Mañaara, there was a guttu family called Doninja Gothli. In this family, there was a couple called Satya Bannar and Lakshmi. Since they had no child, they prayed to Brammabermeru ${ }^{2}$ to be blessed with a baby. Hearing this prayer, Brammabermeru ordered one of his followers to come into being on the earth as a human child. Satya Bannar found this child when walking along the riverside and took him into their home. The couple raised the child with joy. Since they had found the child that they had been longing for, they named the child Nādu ('to seek'). When he had grown up and acquired an education, Nādu started to teach martial arts at a place called Nādi Doninja.

Satya Bannar achieved fame as one of the most efficient subjects of the king. Because he stood high in his master's favour, however, another subject killed him out of fierce jealousy. Due to the deep sorrow of losing her husband, Lakshmi soon killed herself. Nādu, his foster parents now both dead, stopped believing in any gods. 


\section{The travels of Nädu and the king}

Before the birth of Chandrashekara, who would become king, his maternal uncle had taken a vow that if a nephew were born, he would present offerings to the gods enshrined in the Mahālingeśvara temple at Venōr. ${ }^{3}$ To fulfil this vow for his uncle, the king would have to make a pilgrimage to the temple. The offerings consisted of a small golden statue of a child, a silver cradle, and a handful of coins. Since the king did not know the way to Venōr, he decided to take Nādu as a guide and sent a messenger to him. Nādu received a letter from the king with the message that he should come to the king straightaway. Nādu hurried to the palace, and when he arrived, the king explained why he had called him. Nādu then expressed his resolution to the king: 'Your Majesty, I will accompany you. However, on the way to Venōr, I will never pray to any gods, either in front of a god's statue or in front of a temple'.

The king accepted all Nādu's wishes, including that a white horse and parasol be prepared for him along with a palanquin for the king. Additionally, on the journey to Venōr, Nādu would lead the way, while on their way home, the king would take the lead. The carriers of the palanquin, decorated with flowers, began their journey from the palace and headed towards the temple. After a while, they reached the Manjunātheśvara temple. From there, they went on to the Sbrahmanya temple at Kudupu. In both temples, the king presented offerings to the gods. However, Nādu neither stepped inside the temple, nor got down from his horse. After passing through many other places, they arrived at Nāda Bailụ, where there was a shrine to Brammabermerụ. While the king visited the shrine, Nādu stood outside. At this moment, the deity Brammabermerụ appeared to Nādu and said, 'Now, you can go. When you come back, I will take care of you'. This was the deity's promise to Nādu, who answered: 'I will come back along the way I'm going'.

\section{The battle between Nādu and Brammabermery}

The king and Nādu passed through the vast land of Nāda Bailụ and finally arrived at the Mahālingeśvara temple, where the king dedicated his offerings to the gods. That night, they attended a ritual in Venōr and then started out for home at daybreak. On their way home, the king took the lead on the palanquin, with Nādu riding behind him on horseback. When they approached Nāda Bailụ, a Brahman wearing a sacred thread suddenly took the reins of Nādu's horse and stopped them. The Brahman was actually the deity Brammabermerụ, who had disguised himself as a human being. Nādu and Brammabermeru glared at each other for a second, and then they began a great battle, which culminated in Brammabermerụ turning Nādu's horse to stone and forcing Nādu to disappear. When the king turned back, he could not find Nādu. When he prayed for him to come back, he heard a strange voice: 'Today, the curse on Nādu has ended. He will appear at Kinnimajālụ in Perra'. 
In this way, Perra became the land from which Nādu appeared as Balavāṇ̣̣i.

The oral epic summarised above shows the ambiguous relationship between Balavāṇ̦i and Bramma (Brammabermerụ). Balavāṇdi, once a follower of Bramma, was banished to the human world by his master's curse and then killed by him in order to be transformed into a büta. As the next section illustrates, despite this antagonistic relationship with Bramma, Balavāṇdi took the brammalinga to Perar to install it in the village shrine. Next, I will explain the pāḍdana narrating the encounter of Balavāṇdi and Arasu (uḷ̣āklụ).

\section{The story of Arasu, king of the būtas}

\section{The u!la $k$ l!}

Once upon a time, there were four guttu families. The names of the families were Kanaka Bottu Janana, Gundya's Janana, Kelinga's Janana, and Tumbe Jāla Janana. Though each family had paddy fields, none of them had buffalo with which to cultivate the land. The guttu heads then heard that a fair for buffalo would be held in a place called Thippinge Neshēnki. They sold their bangles for 300 varaha $^{4}$ and tied this money in their shawls. They also acquired 700 varaha by selling their chains and put this money in their pockets. After taking breakfast, the four guttu heads started their journey with their retinue.

After passing through many places, they finally reached Tippinje Neshēnki, where they found more than 4,000 buffalo. Each chose a buffalo to his liking and brought it to a place called Gujjaragoli. Resting there, they saw four men carrying coconuts and split coconut leaves and asked them, 'Why are you carrying those things?' 'We are taking them to the nēma for the ul!āklu at Chavundeśvari. Why don't you come with us?' 'Sure, let's go. Please guide us'. Leaving their retinue and buffalo, the four heads set out for Chavundeśvari.

They arrived at Chavundeśvari in time for the performance of the nēma for the ul!̣āklụ. The uḷāklụ and four guttu heads saw each other, and the ul! alklu gave them areca flowers, coconuts, and betel nuts. When they returned to Gujjaragoli with these things, however, they could not find their retinue nor their buffalo. They searched for them everywhere, but it was all in vain. 'What sort of magic is this? What went wrong?' they lamented. They decided to visit the ullakklụ again to consult him about what had happened. They pleaded to the ul! âklụ, 'When we came back with prasāda, we found neither our retinue nor the buffalo. Please make them appear again'. The ul!āklụ asked them, 'If I do this for you, what will you do for me?' 'We will 
build shrines for you in our four countries'. The ullāklụ seemed satisfied with this answer and said, 'Go back to the same place. You will find your buffalo and retinue'. When they arrived back in Gujjaragoli, they found their buffalo and retinue, just as promised. Surprised and overjoyed, each of them went back home and built a shrine for the uḷāklụ.

\section{Balavāndi's invitation to the u!! ăklu}

The ullāklụ decided to make a pilgrimage to the east of the Māveri Ganga to perform ablutions. He went there from his palace on a palanquin, and after performing ablutions, he and his retinue started on their way back home. On this return journey, they took a rest at a place called Antharanga Katte. Balavāṇ̣i then heard that the uḷāklụ was coming and declared, 'We don’t have a king of the daiva in our country. I will take the uḷạklụ here'. Balavāṇḍi went on horseback to meet the uḷāklu at Antharanga Katte, greeting him when he arrived. They liked each other immediately. Finally, Balavāṇḍi told the uḷāklụ his wish: 'Please come to our land. There is no king in our country'. 'I could go there, but your country is so poor and small. There are thousands of būtas by my side in my palace. It will be difficult to take them to your country'. 'Then I will make all but your favourites disappear by throwing this stone into the bush'. 'All right. Except for Kāntiri Jumādi and Panjūrli, you can erase the figures of all the other būtas'. But then the ullāklụ pointed out another problem: 'Nāgabramma is not in your country. I need a daily ritual. If Nāgabramma is not there, I won't go'. 'Then I will definitely take Nāgabramma for you', Balavāṇdi promised. Satisfied with that answer, the ullāklụ sat back on the palanquin.

\section{Balavāṇ̣i's and Arasu's visits}

Balavāṇ̣̣i and Arasu passed many places before arriving at Kattalsar, where they found the house of Madurāya Pejattāya (an ancestor of the Pejattāya family). The two deities changed themselves into humans and visited his house. Madurāya welcomed the guests and offered them a bowl of milk. Sitting on a swing (ujjālu) in the hall, they drank it. After some time, when Madurāya was not paying attention, they vanished. His eyes filled with tears from the shock. After a few minutes, however, the guests appeared again in front of him and said:

Pejattāya, you gave us a bowl of milk, which we accepted since you clearly represent a very pious family. From now on, therefore, aside from the shrine to Brammabermerụ, your house will be the only one allowed to be two stories and to have a swing. Moreover, among the Brahman families, your house will be the first.

Madurāya then covered his head to show his faith in the deities. 
Next, the deities visited the Kabetti guttu house. They changed themselves into humans again and said to Dugganna Baidya, the then head of the house, 'We are hungry. We need some food'. Dugganna went inside the house to prepare lunch for the guests. When he came out with a bronze pot filled with water, however, he could not find them. 'Did I do something wrong?' On the verge of tears, Dugganna considered what had gone wrong. After a while, though, the guests reappeared in front of him and Balavāṇdi said:

In truth, we did not come here to have lunch. I have brought the ul! âkḷu here, as I know you are one of his devotees. You should prepare food for the ullāklụ, as long as the sun and moon exist.

With great joy, Dugganna accepted these orders.

The deities then visited the Mundiabețu guttu house, whose head was a Jain woman called Koratāi Balardi. After a formal exchange, they told her their request: 'You should build a shrine with a māḍa for us'. She faithfully accepted this order. With the help of all the villagers, but laying the foundation stone herself, she built a guṇ̣a for Brammabermerụ, a māḍa for Arasu, and a hall (cāvaḍi) for Balavāṇdi. Thereafter, all the land from Aggidaimata to Dambepāpu was governed by Balavāṇ̣̣i.

The then head of the Bernotțu ${ }^{5}$ guttu (the second guttu family) was a person called Bale Semita. The deities again changed themselves into humans and visited his house. 'We are thirsty', they said. Bale Semita ordered one of his servants to bring and peel tender coconuts for them. As soon as the guests drank the coconut juice, they disappeared. 'They were just sitting here. Where could they have gone? What a marvel!' he shouted. At that very moment, the guests manifested themselves again and said:

Bale Semita, we are not humans. We are daivas. I am Balavāṇdi and have brought the ul!āklụ here. We have already visited several places and have now come to your place with love and respect. For us, the first place is the Mundabețu guttu and the second is the Bernoțtu guttu. We will also create other guttu houses. I will bring Nāgabramma there too. In cooperation with these guttus, you should build a guṇda for Nāgabramma, a māạa for Arasu, and a cāvaḍi for me. If you build all these shrines, we will protect all the people in Perar.

The first through the 12th guttus belonged to the Banta community, and the 14th through the 16 th guttus were Püjāri. ${ }^{6}$ These were the guttus created by Balavāṇ̣i in Perar.

\section{Balavāụdi's acquisition of a brammalinga}

Balavāṇdi went to a place called Kaje to claim the brammalinga of Manibottu Brammērụ. ${ }^{7}$ A būta called Kandettāya ${ }^{8}$ objected, however, to Balavāṇ̦̣i taking this linga. They battled, but finally Balavāṇ̣̣i succeeded 
in taking the linga to Perra. Kandettāya went after Balavāṇ̣̣i and stopped him near Perra: 'As you are receiving rituals here, please make the people perform rituals for me too'. Balavāṇ̣i accepted this request.

In this way, a guṇụa for Brammabermerụ, a māḍa for the uḷāklụ, and a cāvaḍi for Balavāṇ̣̣i were founded in Perar. Balavāṇni furthermore gave these orders to Koratāi Balardi, Bale Semita, and the other guttu heads: 'Perform a daily ritual for Brammabermerụ. Offer a votive light for us every day. And perform the nēma once a year. If you keep these promises, we daivas will protect you'. With the help of the villagers, the 16 guttus organised the nēma to begin on the night of the full moon.

As we have seen above, the pāḍdana describes how the deities came to Perar. Aside from Balavanndi, who is believed to have appeared from the land of Perar itself, the other royal būtas are regarded as strangers from elsewhere. The păḍdana also shows the centrality of Balavāṇni in Perar, as well as the inseparable bond between Balavāṇ̣i and Bramma.

Another interesting aspect of these stories is that when Balavāṇdi and Arasu changed themselves into humans and visited the houses, they complained of hunger and thirst and were offered food and drink by the head of each house. The deities' visits to the guttu houses and their reception by these heads constituted the event that modelled the ensuing relationship between the butas and the villagers. In Perar today, the sequential order in which the deities are believed to have visited each house is regarded as grounds for the ranking of the guttu houses. In addition, a series of events are re-enacted in the nēma, such as the deities' visits and their reception by the guttu heads, the people's devotion to them and their promise to organise the nēma, and the deities' promise of protection.

As we will see later, the mutual exchange of offerings and blessings between the deities and villagers in the rituals has more significance than the mere re-enactment of mythical events. Rather, this performatively affirms and actualises the present rights and ranks of each guttu house. At the same time, it is a chance for villagers to reconfirm the supreme power and authority of the deities who give them protection and blessings. Part of the significance of the nēma is to perform this mutual transaction again and again in front of the villagers. Next, we will see the pădidana which describes the relationship between Balavāṇ̣̣i and Pilicāmuṇụi.

\section{The story of Pilicāmuṇ̣̣i, the būta of the wild tiger}

Knowing that Arasu had come to Kinnimajālụ, a būta named Pilicāmuṇ̦i travelled there from a place called Balolli Nadu. He played a flute on a hill called Kompadavụ while waiting for his chance to see Arasu and Balavāṇụi. He then lit a torch with bronze grip and began looking for the ullạklụ. Meanwhile at the nēma, Balavāṇ çi came to know of the stranger's visit and 
said, 'A daiva has come. I will get him to go far away, and then I will come back'. Balavāṇ̣i then changed himself into a human. When Balavāṇ̣i got to Bolinji Guḍde, he saw the daiva of Balolli Nadu. 'Where are you from, and where are you going?' Balavāṇdi asked the stranger. 'I came here to see my u!̣̣āklụ', the būta replied. Balavāṇ̣̣i responded, 'He is not your u!̣̣ākḷ̣, but mine!' The two quarrelled, and, finally, Balavāṇ̣i said, 'Never get in my way! If I kick you, you will be seriously injured'. Pilicāmuṇ̣i retorted, 'Well, if I kick you, you will be split into two!' 'Let us see how you go', Balavāṇdi said, drawing three lines on the ground with his sword. 'If you cross these lines, you will receive the curse of the Manjunatha god in the Kadri Temple'. Balavāṇ ḍi then went back to the nēma.

After some time, Pilicāmuṇịi managed to cover the three lines in Bolinji Guḍḍ with leaves and then went directly to Kinnimajālụ, hiding himself in a field in front of the shrine. Bale Semita, the head of the second guttu house, happened to come to that field shortly thereafter to harvest bananas for Balavāṇdi. Pilicāmuṇụi kicked him, killing him instantly. After hearing of this incident, Balavāṇ̣̣i called on Pilicāmuṇ̣i: 'If you are so powerful, then bring him back to life. After that, make my sword in Balolli Nadu fall into my courtyard!' 'If I do that, what will you do for me?' Pilicāmuṇịi asked. 'Now, the nemma is held for two nights; one is for me and the other is for Arasu. We will add a third night for you. In addition, we will give you the right to respond to people's consultations'. Accepting this challenge, Pilicāmuṇ̣i made quick work of bringing Bale Semita back to life and making the sword fall into the courtyard. Thereafter, Balavāṇ̣i, Arasu, and Pilicāmuṇ̣̣i were known as the 'three uḷâklụ on one couch' (mūve rullākulu onjji mañcāvudu ullerụ). A new shrine to Pilicāmuṇdi was also built on the hilltop.

This pāḍdana shows how Pilicāmuṇdi came to be enshrined in the būta shrine in Perar. As already seen, among the būtas enshrined there, the status of Pilicāmuṇ̣i is rather unique. Unlike Balavāṇdi who appeared in Perar itself, or Arasu and Bramma who were invited there, Pilicāmuṇ̦i arrived uninvited in Perar and then had trouble with Balavāṇụi. Accepting Balavāṇdi's challenge, the butta showed his power and earned the right to be worshipped in this land. Among the promises that Balavāṇ̣̣i made Pilicāmuṇụi in the pāḍdana, 'the right to respond to people's consultations' is especially significant. In the nēma, the ritual for Arasu is held on the first night and that for Balavāṇdi is held the following day from midnight to dawn; the longest ritual, from dawn to the afternoon on the final day, is for Pilicāmuṇdi. On the same day, there is a ritual called vākụ piripuni, in which devotees consult Balavāṇṇi and Pilicāmuṇ̣̣i about various problems and receive their judgement. 'The right to respond to people's consultations' accounts for the role of Pilicāmuṇịi in this ritual.

This section has outlined the pāḍdana focusing on the royal būtas in Perar. We now turn to the păḍana regarding the relationship between the guttus and the deities, focusing on the Mundabatțu guttu and the Alake guttu. 


\section{The pāḍdana on the deities and guttu families}

\section{The Mundabețu guttu and the deities}

About a thousand years ago, the Mundabetțu guttu, like the other guttus in South Kanara, belonged to the Jain community. A woman called Koratāi Balardi was the last descendant of this Jain family. When Balavāṇdi and Arasu changed themselves into humans and visited her house, she was in charge of the whole family. She asked her servant to bring them a glass of milk, and the guests drank it. Then she went into the house to bring them betel nuts. When she came outside again, the guests had disappeared. She called to them, but heard only a strange voice from the other end of the house: 'Oh!' She approached and called again, but the same voice replied this time from the kambula field: 'Oh!' She was surprised and began to wonder who the guests had been. Although she could have asked their identity when they came to the house, this would have been impolite. If guests did not volunteer their identities, the host could only ask them after providing them food and drink.

That night, the guests appeared in her dream and said, 'We are daivas. We need a shrine in this village. We have already chosen the place'. Balavāṇdi added, 'We have appeared at Kinnimajālụ. With the help of the sixteen households we have visited, together with the whole village, you should build us a shrine and worship us'. Following these orders, Koratāi Balardi built the village būta shrine and organised the nēma. Since she had no children, she received a brother and sister from a Baṇta family in Gurupura, who succeeded her in the Mundabetțu guttu.

\section{Alake guttu and the origin of the mukkäldi}

About 800 years ago, there was a house called Kukkunja, the sub-guttu (ulaguttu) of the Alake guttu family. All the guttu houses were Jain, but then a Baṇta brother and sister from a clan called Kundarannāya came to live in Kukkunja. One day, the sister visited the main Alake guttu house. When the guttu people asked her identity, she told them her clan, even though her brother had told her not to tell anybody this secret. When she revealed their clan's name, the brother, who had been working outside, was suddenly possessed by Balavāndị. The deity had been searching for someone belonging to the Kundarannāya clan to serve her as mukkāldi, since this would adhere to the custom of matriliny called aliyakattu [aliyasantāna kațtụ]. The Jain guttu family eventually bequeathed to the brother and sister their land and title. After this, the guttu was passed on to the sister's children, and their family assumed the title of Alake guttu and the status of mukkāldi.

$*$

These oral epics show the relationship between the būtas and the Mundabettu and Alake guttu families. It is said that the guttus who governed the land when the people started their relations with the deities were 
Jains. Today, however, 12 of the 16 guttu families in Perar are Banța. Each of these 12 families is said to have inherited its title and status from a Jain family who had relinquished them and the land. In the case of the Munḍabețu guttu, it is said that Balavāṇ a Jain family as 'the first guttu'. After that, the Banta brother and sister adopted by Koratāi Balardi succeeded to this estate as well as the guttu title. In the case of the Alake guttu, it is said that Balavāṇdi first selected the clan called Kundarannāya to undertake the role of the mukkāldi. A brother and sister of this clan then inherited the title of guttu along with the estate from the Jain family.

It is noteworthy that in both cases the ancestors who are said to have succeeded to the title of guttu were a 'brother and sister'. As we will see in Part Two in more detail, in the matrilineal Banța community, the tie between brothers and sisters is very important. Brothers assume the role of head of the family as well as ritual roles such as gaḍipatinārụ and mukkāldi. This role and status are then inherited by his sister's son. Meanwhile, the estate and deities worshipped by the family (kuțumada büta) are passed on from the sister to her children. To this day, the Banța community still maintains this system of matrilineal inheritance. It is a system based on the ties between brothers and sisters, as well as on būta worship, which enables the maintenance of the kutuma as a whole.

As we have seen in this chapter, pāddanas are stories about the original relationships between humans and deities, especially about the relationships between the guttu families and the royal būtas. Referred to as 'matters of history' by villagers, these serve to warrant each family's status and the relations among families in the village. Pạddanas are not holy scriptures, but oral epics that are spread and passed down through ritual performance. Since there is always a possibility for a pādddana to be slightly changed in a performance, its contents regarding the ranks and roles of the families often become points of controversy among villagers.

It is also interesting that most of the pạddanas examined in this chapter contain episodes that show the mystic power of the bütas, with deities vanishing (māya äpuni) or making someone disappear (māya maḷuni). This suggests that in the human-būta relationship, the coming of bütas is always followed by their disappearance; people perceive that the vanishing of a deity who has appeared as an actual being demonstrates that it fundamentally belongs not to the realm of jōga, but to the realm of māya.

The relationship between the deities and people described in the păddana is not only sung as oral epics. In the nemma in Perar, it is also partially performed by the mukkāldi, the dancer-mediums, and the heads of the guttus. The people participating in the nema thus experience the mutual transactional relationship with the bütas through ritual performance, as we will see in the next chapter. 


\section{Notes}

1 The oral epics recorded in this chapter are based on the stories narrated by Gangādara Rai (interviewed on 3 July 2008), Bālākrishna Shetty (interviewed on 2 July 2008), and Narasouna Pejattāya (interviewed on 21 July 2008). As discussed in Chapter 8, part of the pạḍdana regarding the village būta shrine in Perar was recorded and edited into a Kannaḍa pamphlet by folklorists. I have also referred to this pamphlet.

2 Brammabermerụ is another name for Bramma. This deity is also called Nāgabramma.

3 A vow made to perform certain rituals or to offer gifts to deities is called parake (Upadhyaya 1988-1997, p. 1934). In matrilineal communities such as those of the Banța, a maternal uncle often makes a vow praying for the birth of a child for his sister.

4 Varaha was the standard 3.4-gram gold coin in the Vijayanagara period.

5 Bernotttu guttu is another name for the Brānabetțu guttu. Similarly, the Mundabetțu guttu is also referred to as the Mundoțț guttu.

6 Today the 13 th guttu is Kudubi.

7 There is a shrine to Bramma in Kaje, and the deity is called Manibottu Brammērụ.

8 Kandettayya is one of the five būtas one rank below the three royal būtas. 


\section{Dances, oracles, and blessings in the ritual}

The nēma starts on the night of the full moon in the month of māyi and is held for three days and three nights. In the nēma, the people and the būtas, incarnated in dancer-mediums, interact in several rituals. The ritual process provides us many clues regarding how to consider the question presented in Chapter 1, that is, how people create their lives and umwelt through encounters with nonhuman others. In this chapter, I will describe the process of the nema in detail, in order to provide a basis for the theoretical analysis in the next chapter. ${ }^{1}$ I will focus on the performances of the Pambada dancermediums, of the mukkāldi, and of the guttu heads in the rituals for Balavāṇ̦i, Arasu, and Pilicāmuṇị. The nēma consists primarily of five main rituals: from the previous night to the next morning, there is a ritual called $p \bar{u} v \varepsilon$, in which a flag is hoisted at the village büta shrine; from the first night to the next morning, there are rituals for Arasu and Balavāṇdi (puṇname); on the second night, there are rituals for Jumādi and Banța; from dawn to the afternoon on the third day, there is a ritual for Pilicāmuṇ̦i and vākụ piripuni; and on the final night, there is a ritual involving taking down the flag (kodi jāpuni).

\section{The day before the nēma}

One day prior to the nēma, ritual workers build a wooden gate on the north side of the village būta shrine. This is the starting point for the rituals. Everyone and everything concerned with the nēma is supposed to enter the shrine precincts through this gate. In the evening of that day, worshippers hold a ritual called padiari pattuni. In this ritual, the mukkāldi gives 5 serru of rice to Jayānanda Pambada, the dancer-medium of Pilicāmuṇ̦i, and grants him permission to perform in the nēma. ${ }^{2}$

Now, it is $10 \mathrm{pm}$ in the village. The beginning of the nēma is just a few hours away. Amid the shadows of the night, every building in the precinct sparkles with decorative illuminations. Several children, set to attend a ritual called kanciul bali later tonight, sit in the northern corridor with their mothers, who straighten the children's clothes and put jasmine flowers in the girls' hair. Some people chat in the outer garden as everyone waits for the ritual to begin. 
Shortly after $1 \mathrm{am}$, a group of people carry the palanquin down a footpath between the paddy fields. Fireworks explode into the sky, and drums and horns start to reverberate throughout the night air. Torches of fire and flashes of smoke pots light up the procession. Illuminated are the musicians playing the drums and horns, the guttu heads in their white clothes, and the many ritual workers carrying torches, big red and white umbrellas (sattige), a red banner (naḍ cōrṇa), a silver umbrella (bolgoḍ), a silver mask (muga) of Pilicāmuṇịi, a wooden couch (katterimanc), and the palanquin with its various sacred objects. And when they all reach Banțakamba, the horns blare to a crescendo.

The mukkāldi possessed by Balavāṇḍi is suddenly shaking all over. His eyes go wide, his limbs stiffen. He holds a silver sword (kadsalc) and bell $(m \bar{a} d a)$ in each hand. Strings of jasmine flowers hang over his chest, nearly reaching his long white loincloth with its silver belt. A Maḍdyele worker holding the long pole of the silver umbrella now also finds his skinny body trembling all over uncontrollably. The bütas are here. Shivering of the body is the most conspicuous sign of possession by a deity.

After a while, the party then starts out from Bantakamba to the village būta shrine. A white cow (basava), a symbol of auspiciousness, is led through the ritual gate by two of the men. Ordinary villagers gather around the ritual gate and gaze at this procession. Women hide behind the crowd for fear of being seen by the mukkāldi possessed by Balavāṇ̣i (Mukkāldi-Balavāṇdii). Balavāṇḍi, who is believed to be androgynous, is said to become jealous of women when she sees them. ${ }^{3}$ Though she likewise becomes somewhat jealous of men when she sees them, it is especially prohibited for women especially to come within view of Balavāṇdi, since the deity will become particularly enraged if she sees them. The procession passes through the ritual gate, marches around the shrine clockwise, and enters the precincts.

At $3 \mathrm{am}$, a white flag is raised on a flagpole in front of the Bramma guṇụa. The asrāṇna offers a votive light at the Bramma guṇụ, māọa, and koḍiyaḍi (altar). The ritual called tudara bali then begins. Accompanied by the sounds of instruments, the mukkāldi, the guttu heads, and the carriers of the sacred objects walk around the kodiyaḍi, māḍa, and Bramma guṇua nine times. After this ritual, the dressed-up children come before the altar while their fathers and brothers carry votive lights. Following their male kin with their offerings to the bütas, the children walk around the altar and māda holding areca flowers. This ritual is called kańciụl bali and is held for the children's health and for the resolution of family problems. At $5 \mathrm{am}$, after a dialogue (nuḍikațtu) between the gaḍipatinārụ and Mukkāldi-Balavāṇ̣̣i, the gadipatinārụ hands three coconuts to the mukkāldi, who then pours the coconuts' water on the ground. ${ }^{4}$ With this performance, the rituals stretching from the previous night to the dawn of the first day of the nēma come to a close. 


\section{The rituals to Arasu and Balavāṇ̣̣i}

\section{The ritual to Arasu (the first half): gaggara decci}

By $8 \mathrm{pm}$ on the first day of the nēma, the corridor of the village būta shrine is already filled with crowds of devotees. Most of them first visit the Bramma gunda and pray in front of it. They throw money into an offertory box and receive prasāda from the Maḍdyele worker who guards the altar, which is surrounded by a thick curtain of white and orange flowers. Shining brilliantly on the altar covered with jasmine flowers are sacred objects such as the silver masks of Arasu and Pilicāmuṇụi, Balavāṇụi's sword, and silver statues of an elephant, a tiger, and Balavaṇ̃di on a horse. On the north and south sides of the altar, there are two pedestals (carva) on which offerings are set.

Near the main entrance of the precinct, there is a wooden horse (kudure) and a big halo-like adornment called ani for Balavāṇdi. A Pambada man sits cross-legged on the ground beside these objects making up his face under the fire of an oilcan. This man is Jayānanda Pambada, the dancer-medium of Arasu. A red cloth bound across his forehead holds his hair back as he carefully makes up his face to become the deity. He paints his face yellow and outlines the contour of his face from forehead to cheekbones to jaw with a lace-like design called arudala. He shades his eyes black. His eyebrows become arches from the bridge of his nose. His face thus made up, he holds up with both hands golden ornaments decorated with jasmine flowers to the fire of the oilcan for a moment, and then hangs these on his ears. He next puts on a red costume embroidered on the back with images of the sun and moon. He slips silver bangles onto his arms and wrists and places on his head a golden crown decorated with red kêpla [Ixora coccinea] flowers.

Meanwhile, under the canopy of the altar, the mukkāldi of Balavāṇdi also prepares for the ritual. He wraps his hair in white cloth, prays to the altar, and picks up the bell. Horns suddenly reverberate throughout the precinct, and his body starts shaking. Receiving a burning torch from a Maḍdyele worker, the mukkāldi, who is now possessed by Balavāṇ̦i, whirls the light in front of the altar. He starts walking around the altar and māḍa, and the guttu heads and other ritual workers follow him.

At $9 \mathrm{pm}$, the mukkāldi and Jayānanda face each other in front of the altar. Jayānanda holds gaggara (heavy flat bells) in both hands, and then his body starts trembling. Supported by his fellow Pambada, he puts the gaggara on his ankles and wraps a tiri (a skirt made of torn coconut leaves) around his waist. He steps forward and bows to the altar. The gadipatinārụ next places garlands of flowers around Jayānanda's neck, and the ritual workers light a fire on the carva. When the fire is lit, Jayānanda starts trembling all over and wriggling his upper body. Jayānanda possessed by Arasu (Jayānanda-Arasu) starts performing a dance called gaggara dīpuni, and then runs through the precinct with two torch-wielding Maddyele workers until he reaches the head of the Pejattayya, who sits in his seat for honoured guests. Jayānanda-Arasu steps lightly to the sounds of the horns, and he 
starts talking to the Pejattāya head through gestures with his body and hands. He draws close to the Pejattāya head's face to look up at him, holds both his arms up in the air, and leans forward to catch his answers. All of these gestures are performed fluently as a part of the dance and steps. Jayānanda-Arasu next darts back to the altar and dances in front of the guttu heads according to their ranks. Through his facial expressions and gestures, he communicates with the guttu heads who stand up in respect and watch his every movement seriously.

Although these interactions between the devotees and the deity incarnated in the medium are relatively common in manner and process, the relationship between the gadipatinārụ and the deity is special. During the nēma, the gadipatinārụ occupies the position closest to every deity manifesting itself in the ritual. It is to the gadipatinārụ that the deity incarnated in the medium conveys her various requests and indications, and often this involves her communicating her dissatisfaction and anger over people's faults during the ritual. The gaḍipatinārụ follows the deity to respond to her every movement, treats her hospitably, and appeases her anger. Through their mutual interactions in the ritual, the gadipatinārụ and the deity incarnated in the medium create and embody the ideal relationship between būtas and devotees.

After dancing in front of the guttu heads, Jayānanda-Arasu dances facing the Pūjāri priests, who have been waiting near the wooden horse. He then runs through the precinct and dances lightly in front of the altar. As he steps to the sounds of the horns and spins pivoting on one foot, the tiri around his waist flares out from him and the gaggara around his ankles resound. Then he runs off again, weaving his way through the precinct. After again communicating to the guttu heads through gestures, he raises his hands beside his head as if to say good-bye, and then steps agilely around the precinct. After whirling many times, Jayānanda-Arasu seems about to fall on his back in front of the carva, but one of his brothers quickly catches hold of him. At that moment, all the music stops; only the lingering tone of a horn remains. Jayānanda remains held in his brother's arms for some time, before waking up and walking to a corner of the precinct. Only the sounds of his gaggara resonate now.

\section{The ritual to Arasu (the second half): nēma decci}

At $10 \mathrm{pm}$, soon after the gaggara dīpuni finishes, Jayānanda leans on a three-legged stool and starts singing the pāḍdana. Jayānanda's brother, who stands behind him, plays a drum hanging from his shoulder, and they each take turns singing phrases of the pāḍdana. Meanwhile, other Pambadas decorate the aṇi for Balavāṇdi, while in front of the carva, under the fire of torches, three workers braid coconut fronds to make pieces called madalu mudepuni, which symbolise farmland greenery. When the pāḍdana ends, people wander around the precinct in twos and threes, stopping occasionally at a canteen set in the field outside the shrine to have some snacks. 
At $11 \mathrm{pm}$, the mukkāldi possessed by Balavāṇ̦i walks around the precinct along with the guttu heads and ritual workers, and has a dialogue with the gadipatinārụ. Then Jayānanda, who stands in front of the mukkāldi, dons the costume of Arasu. Compared to the one for the previous ritual, this costume is heavily equipped. He drapes a purple cloth over his shoulders and his red upper garment, then adds a layer of red and green textile and blue cloth, and then drapes a red and gold textile on top of all of these. He next lifts a huge halo-like ani ${ }^{5}$ onto his back and ties it around his waist tightly. $\mathrm{He}$ also secures a semi-circular table called jakkelani around his waist. To complete the costume, a long board (kadar mudi), on which the mask of Arasu is tied, is placed in the centre of the ani.

At 12 o'clock midnight, Jayānanda prays to the altar and receives a silver sword. To the sounds of horns, the guttu heads throw petals and grains of rice over him — at that moment, Jayānanda starts trembling all over. This is the start of the ritual called nēma decci. Jayānanda, carrying the big ani and holding the silver sword in his right hand and a bell in his left hand, turns slowly in front of the altar. As it is very difficult to turn by himself with such heavy and bulky adornments, several Pambadas hold up the back of the ani and the end of the jakkelani to help him. Jayānanda-Arasu walks around the altar, goes to the head of the Pejattāya, turns in front of him, and comes back to the altar. With his sword raised overhead, Jayānanda-Arasu gives an oracle to the guttu heads. Each guttu head puts his palms together and listens attentively to the deity's words.

Jayānanda-Arasu then hands his sword and bell to one of the Maḍdyele workers, receives a green coconut, and gives it to the gadipatināru with a blessing. He receives another coconut decorated with areca and kēpla flowers, picks off some of the petals and touches them to his forehead lightly, and throws these towards the guttu heads. The transfer of the coconut and petals shows the deity's blessings for the guttu heads and other devotees. After rinsing his hands with water, Jayānanda-Arasu takes up his sword and bell again. Shaking the bell, he trembles all over furiously, and when a horn reverberates, he suddenly stops moving as though he has breathed his last.

\section{The ritual for Balavāndi (the first half): gaggara dīpuni}

A little after $1 \mathrm{am}$, a youth with a dark red cloth on his shoulders and a red and green loincloth starts roaming the precinct. His tanned, angular face is distorted and black hair falls in waves onto his shoulders. A hush falls over the hundreds in the precinct, with only his roar of 'Whoa-ee!' periodically breaking the silence. The ritual called enne detonuni, in which Balavāṇ̣i incarnated in Yatish Pambada receives sacred oil, has begun. Yatish-Balavāṇdi walks back and forth, dances waving a bronze plate in his hand, and runs to a Maddyele worker waiting near the carva. As soon as the Maḍdyele splashes sacred oil from a mud pot onto him, Yatish-Balavāṇ̣̣i runs out of the precinct on the wings of the wind. 
After some time, Yatish-Balavāṇḍi, who has meanwhile finished bathing at a well near the treasure house, runs back into the precinct with awful roar. Several Pambada workers immediately run to him, put the strap of a drum onto his shoulder, and give him a drumstick. When Jayānanda, who has by that time undressed himself and removed his make-up, starts singing the pāḍdana, Yatish-Balavāṇḍi, his body stiffening, starts playing the drum. After a few minutes, Yatish-Balavāṇ̣i suddenly starts off running towards the east, rushing into the crowd in the corridor. He then faints into the arms of the other Pambadas.

Around 2:30 am, Yatish-Balavāṇdi, wearing the gaggara and a gorgeous colourful skirt over red trousers, dances in front of the guttu heads. Two hours later, Yatish-Balavāṇ̣i, who wears an aṇi resembling the huge wings of a butterfly, starts singing the pāḍdana. He then dances around again in front of the guttu heads, who stand up to show their respect for the deity. After dancing, he prays to the altar. The Maddyele splashes water onto him from a bronze pot. He then bows to the altar and returns to the corner of the precinct, the sounds of the gaggara reverberating as he goes.

\section{The ritual for Balavandi (the second half): the fight with Bramma}

A short while after $5 \mathrm{am}$, on a rush mat in a corner of the precinct, Yatish prepares to wear Balavāṇdi's aṇi. His face has changed into that of an intrepid man with a thick black moustache. He puts several thick pieces of cloth over his shoulders, layered on top of his red costume, carries the huge ani that is double his height, and tightens its backboard against his upper body. Since the ani is worn with its base above his head, its top reaches about 4 metres from the ground. In contrast, the silver jakkelani worn around his waist is small, with a radius of about 40 centimetres.

With the aṇi in place, Yatish faces Mukkāldi-Balavāṇdi in front of the wooden horse. Mukkāldi-Balavāṇḍi walks over to Yatish, who is now leaning on a stool, and hands over to him via a Maḍdyele worker a silver sword, the tail of a yak, and a silver stick (birāvu) decorated with jasmine flowers. When the guttu heads behind Mukkāldi-Balavāṇ̣i lean forward and throw petals and grains of rice onto Yatish, he immediately begins trembling all over. At this moment, the power of Balavāṇdi is believed to have transferred from the mukkāldi to Yatish. ${ }^{6}$

Getting up from his stool, Yatish shakes the huge ani and turns, creating a rush of wind. He steps and dances around the precinct lightly to the sounds of the drums and horns, the ani over his head swaying. Then he walks around the altar and māḍa with the guttu heads and other ritual workers. Several Pambadas walk along with him to support the backboard of the ani. After that, Yatish-Balavāṇdi approaches the wooden horse covered with flowers, while dancing with a sword raised overhead. Assisted by other Pambadas, he clambers onto the back of this horse with the huge ani still on his back. A full blast of drums and horns blares, and the Pūjāri workers pull 
with all their strength the pulley rope of the carriage of the wooden horse. The procession centring around Yatish-Balavāṇ ̣i on horseback moves towards the altar. Several Pambadas, balancing precariously on edge of the carriage, hold the back of the ani to prevent it from falling.

After marching around the precinct, Yatish-Balavāṇdi stops in front of the Bramma guṇa and starts performing the dance of fighting on horseback. He expresses his anger by brandishing the tale of a yak and shaking his upper body aggressively. In these movements, the garlands of jasmine flowers on the ani are torn and scattered all around. Trembling all over, Yatish-Balavanṇi repeats the action of tearing his moustache away in a glow of anger. This dance demonstrates the fight between Nādu and Bramma in the pāḍdana.

After this dance, Yatish-Balavāṇdi dismounts from the wooden horse and comes to the head of the Pejattāya. The day breaks and the precinct begins to fill with growing light. Yatish-Balavāṇdi starts talking to the guttu heads with a voice full of life and rich intonations. He reminds them of the authority of the buttas, who have protected the village and its people, and of the importance of the customs and tradition (kattu kattale) that form the basis of the ritual. He also accuses the people of ritual failure and orders them to correct the errors of their ways. The guttu heads nod along with each word of Yatish-Balavāṇ̣i and attempt to pacify his rage by responding with gestures.

At last, the ritual for Kandettayya, who is one of the followers of the royal būtas, is held. Yatish dances around for a few minutes holding a coconut with a fire lit on top of it. With this short performance, the ritual for Balavāṇ̣i has finally come to an end.

\section{The ritual for Pilicāmụ̣̣̣i and vākụ piripuni}

Before the dawn of the last day of the nēma, several Pambadas begin preparing for the ritual, sitting on a rush mat in a dim corner of the precinct. Jayānanda, who performed the dance of Arasu in the previous ritual, is among them. He is making up his face carefully in order to become the dancer-medium of Pilicāmuṇ̣i in the last and longest ritual of the nēma. At around the same time, to the sounds of drums and horns, the asrānna, musicians, and other ritual workers start climbing the long stairs on the hill behind the village būta shrine towards the Pilicāmuṇ̣i shrine at the summit. When they arrive at the shrine, the asrānnna conducts a ritual to Pilicāmuṇ̣i. When this ritual is completed, they return to the foot of the hill and next perform a ritual to a wooden tiger, the vehicle of Pilicāmuṇ̦ii.

A short while after $7 \mathrm{am}$, when Pilicāmuṇ̣i incarnated in Jayānanda (Jayānanda-Pilicāmuṇ̣̣i) has finished performing the gaggara dīpuni and singing the pāḍdana, Mukkāldi-Balavāṇṇi walks with the guttu heads and other ritual workers around the precinct, halting when they reach the altar. Jayānanda, who wears an aṇi on his back, sits in front of the altar, facing 
Mukkāldi-Balavāṇdi, who raises a sword over his head. At that moment, a Maḍdyele worker ties onto the centre of Jayānanda's aṇi, so that it is surrounded by palm leaves, the mask of Pilicāmuṇdi, its silver tongue thrust out. This ritual is called muga pattuni or muga dipuni, and it is believed to be a vital moment: the moment when the büta śakti fills the precinct. The drums and horns resound throughout the precinct and Jayānanda-Pilicāmuṇ̣i starts dancing with burning torches in his hands. While raising and lowering the torches rapidly, he dances and flaps his skirt of palm leaves. He then receives a sword, yak's tail, bell, and petals from the Maḍdyele. He puts the petals on his forehead lightly, strews them in front of him, and starts dancing again with the sword in his hand.

A little before 8 am, Mukkāldi-Balavāṇḍi, Jayānanda-Pilicāmuṇḍi, the guttu heads, and the ritual workers carrying the palanquin march around the altar and exit through the main gate of the precinct. They walk to the north side of the shrine and pass through the ritual gate one by one. As Mukkāldi-Balavāṇdi and Jayānanda-Pilicāmuṇḍi pass through the gate, a ritual worker pours water from a mud pot onto their feet. They depart from the outer garden and march to Banțakamba.

\section{The ritual at Banțakamba}

By 8 am, the outer garden and precinct of Bantakamba are filled with crowds. It is getting hotter, the strong sunshine reflecting off the ground. Under a big tree in the precinct, Jayānanda-Pilicāmuṇdi leans on a stool with the ani, and the guttu heads stand straight beside him. In front of the small shrine, where it is believed that Nādu reappeared on the earth, MukkāldiBalavāṇdi's possession reaches its climax. He walks up and down trembling all over, suddenly running in a flash to the small shrine, then raising the sword with a roar and striking it against his stomach. ${ }^{7}$

After Jayānanda-Pilicāmuṇụi's dance and the dialogue with the guttu heads, the ritual enters a new stage: from possession and dances to oracles, blessings (nuḍi korpuni), and the deities' judgements. Mukkāldi-Balavāṇḍi, Jayānanda-Pilicāmuṇdi, and the guttu heads stand under a big tree. In front of them, the devotees who desire the deities' blessings queue up in a long line. ${ }^{8}$ Those whose prayers to the deities have been answered also come to give the deity offerings such as jasmine flowers and a silver cradle as tokens of their gratitude. Both Mukkāldi-Balavāṇ̣̣i and Jayānanda-Pilicāmuṇḍi give blessings to each devotee. The devotee then receives a smear of sandalwood paste on a betel leaf as prasāda from a Maḍḍele worker.

A short while after $10 \mathrm{am}$, the ritual called vākụ piripuni starts in Bantakamba. ${ }^{9}$ The people who need the deities' judgement now form a long line and face the deities one by one. The devotee first explains his problem, and then, raising the sword above his head, Mukkāldi-Balavāṇḍi states his view on the issue. He intones in a clear voice, often turning to the gaḍipatinārụ to get his agreement. After Mukkāldi-Balavāṇụi’s statement, 
Jayānanda-Pilicāmuṇụi also states his view on the issue. Though their statements often go in different directions, in most cases they eventually reach similar conclusions. After they receive these words from the deities, devotees receive prasāda and withdraw into background.

\section{The sacrifice and blessing}

A short while after $11 \mathrm{am}$, the long ritual of vākụ piripuni finally concludes. At this time, led by the musicians, Mukkāldi-Balavāṇ̦ii, Jayānanda-Pilicāmuṇdi, the guttu heads, and other ritual workers carrying sacred objects begin marching from Banțakamba to the village būta shrine. The roadside is filled with crowds hoping to glimpse the deities. Before the procession starts, about a dozen Pūjāri youths wearing orange loincloths race from Bantakamba to the shrine. When they reach the shrine, they start pulling the wooden horse's dragrope. Accompanied by the guttu heads and ritual workers, Mukkāldi-Balavāṇ̣̣i and Jayānanda-Pilicāmuṇ̦ii then enter the precinct.

At around $1 \mathrm{pm}$, Jayānanda-Pilicāmuṇdi leaves through the east gate of the shrine and enters the outer garden. When he sits down under the simple eaves there, ritual workers spread out a straw mat in front of him and place on it various offerings such as coconuts, palm wine, and bananas. This is a ritual called the bārne, in which food and drink are offered to the deity. ${ }^{10}$ Unlike for Arasu and Balavāndị, who are believed to be vegetarians, fowls are offered for Pilicāmuṇ̦i. For that reason, the bārne for Pilicāmuṇ̦i is held not inside the precinct but in the outer garden. A short while before 3 pm, the bārne finishes and Jayānanda-Pilicāmuṇ̣i comes back into the precinct. He raises a sword in his right hand, dances around the altar and māḍa, turning around in front of the Bramma gunda, and then falls onto his back. The guttu heads surround Jayānanda-Pilicāmuṇ̣̂i, now sitting with his legs stretched out and leaning against the aṇi on his back. Jayānanda-Pilicāmuṇụi looks up at the guttu heads, holds the sword towards each of them, and gives them blessings. After a short while, Jayānanda puts on the slim mask of Panjjurli (the deity of a wild boar) and then dances in front of the altar. With this dance, the ritual to Pilicāmuṇ̦i, which started at dawn, finally draws to a close.

\section{Ritual transactions between deities and people}

As we have examined thus far, the intimate yet tense relationship between people and deities is condensed in the process of the nema in Perar. In the nēma, the guttu heads interact with the bütas in various ways. The most significant form of their interaction is the mutual gifting between the guttu heads and the bütas. The guttus offer the deities a part of their farm products, which embody the fertile śakti, along with human labour and services. The deities receive and consume these offerings and, in return, give them 
blessings to ensure their future prosperity. The bütas also request that the nēma be continued, and the guttu heads give them their word. Through this interaction, the agreement between the deities and the villagers, which is said to be based on the ancient pledge between Balavāṇdi and Koratāi Balardi, is renewed.

This mutual gifting relationship between the villagers and bütas can be described as the transactional network (Appadurai \& Breckenridge 1976, p. 195) of humans and deities. Through the mutual gifting in the ritual, deities and devotees are placed in a transactional network in which they make each other partners. The deity becomes the 'special person' who is the recipient as well as the sender of the gift, the core of the distribution of resources. Regarding the transactional network and the deity's personhood, a more detailed examination follows in the next chapter.

Through the interaction between the bütas and the guttu heads, the hierarchy of the guttu houses is publicly reconfirmed and renewed. The deity, incarnated in a dancer-medium, dances in front of each guttu head and calls the name of each house and property in order. The deity also gives blessings to the guttu heads according to their ranks. As I have discussed, the ranks of the main houses in Perar are based on the ritual hierarchy in buta worship. As such, the nēma gives the villagers an opportunity to manifest and performatively approve the ranks of these guttus.

As seen above, what is essential in the village butta ritual is the mutual interaction between the deities and the guttu heads and other villagers. The success of the nēma is thus judged on the following criteria: the deities smoothly possess the mediums and receive offerings from the guttu heads; both the deities and guttu heads renew the ancient pledge; and all the rituals are concluded with the deities' blessings. Through a process that demonstrates the intimate relationship between the bütas and the villagers, as sung in the pāddana, the roles and statuses of the present guttu heads are approved, and the harmony of the entire village is secured.

In practice, however, the ritual always involves instability and crisis. Būta worship in general is based on the customary law called kațụ. Kațtu indicates conventional law as a whole, and it determines every ritual practice in detail. The details of the kațụ regarding būta worship are said to be known to only a few people such as the gadipatinārụ and mukkāldi. Moreover, the kattụ here involves not only concrete rules regarding ritual practices, but also people's proper attitudes and devotion concerning būta worship.

Though each ritual is supposed to be conducted in accordance with the kattụ, in reality, some changes or unanticipated failures often occur during the ritual. Some of these changes and failures are called out by the deity incarnated in a medium as mistakes that cannot be disregarded. The deity censures the guttu heads harshly and orders them to conduct the ritual properly, based on the kațtu. In the büta ritual in Perar, it is mainly the role of Mukkāldi-Balavāṇ̣i to indict the villagers for their ritual mistakes. When the gaḍipatinārụ and other ritual workers break the customary law 
or neglect their duties, Mukkāldi-Balavāṇdi warns that he will not merely no longer protect them, but will actively cause them misfortune (būtoda upadro). For example, in a ritual held in the second guttu's house, MukkāldiBalavāṇḍi expressed fierce anger, and accused the devotees of ritual mistakes and in-fighting:

Until yesterday, I raised my sword and blessed Perra [the old name of Perar]. But you have made me break the ancient promise [to protect the village and its people]. Never think that I am a deity who breaks the kattụ ... I am the governing deity. If you break this promise, I will show you!

(23 August 2009)

In oracles, the deity often uses euphemistic expressions, and thus his/her intentions are interpreted in myriad ways. For example, although in this oracle, Mukkāldi-Balavāṇdi did not state clearly what he thought was the problem, the villagers conjectured that the deity was expressing his anger about the disputes over the management of the village būta shrine. As shown in this oracle, the relationships between people and būtas are not always one of intimate, mutual appreciation and blessings; often it is a risky interaction, invoking fear and anxiety. While the roles and statuses of the guttus are based on customary law, they are not permanently guaranteed, but rather depend on the judgements of the deities. Thus, people always anticipate the būtas' anger and have developed skills for soothing it so that they might re-establish the proper relationship.

As I have mentioned before, the rights and duties given to the people concerning the būta ritual are called adikāra. Based on the above investigation, we find that the devotees desire and execute the adikāra based on the approval of the deities; at the same time, the deities often give the adikāra to devotees compulsorily or deprive them of the adikāra. Meanwhile, through the villagers' entreaties in the nēma that the bütas bless and protect them in exchange for their devotion, the butas' supreme authority over them is confirmed and approved in public. This means that the villagers verify and reinforce the būta's adikāra towards them.

In the būta ritual, the guttu heads and other villagers are granted rights and statuses in exchange for their ritual services. However, their rights and statuses are kept unstable, since the bütas' supreme authority is regarded as the ultimate source of all entitlement. In this sense, būta worship cannot be interpreted merely as a way to justify and stabilise the prestige of the ruling class in village society (e.g. Gowda 2005). The būta ritual certainly provides particular rights and interests to the devotees, but at the same time, it always reminds them that these rights and interests are never permanent but are tentatively granted to them only through their negotiation with the butas.

This reminder seems to be an important reason why people continue to strive to conduct the būta ritual, to give offerings to the būtas, and to 
interact with the deities to reconfirm and actualise their own adikāra performatively. As we will see in Chapters 12 and 13, this is a vital point to keep in mind when we analyse the complex situation in which people who have widely varying interests in their daily lives nonetheless share the position of büta devotee and temporarily create a ritual community through participation in the būta ritual.

\section{Notes}

1 The description of the nēma in this chapter is based primarily on participant observation of the annual ritual in the Perar būta shrine from 11 to 13 March 2009.

2 According to Jayānanda, he brings the rice and spices received from the mukkāldi to his home. He and his family offer chicken and roti made from the rice to the deity and eat them.

3 Since Balavāṇdi has feminine aspects, saris and jasmine flowers are offered to this deity in the nēma.

4 Mukkāldi-Balavāndịi has very little food or drink offered to him. He is said to receive only the 'air' of offerings. This act of pouring the coconut water on the ground shows that he has received it as an offering.

5 This ani is said to be made of 1,001 coconut leaf bones.

6 This is expressed in Tulu that 'patti māneccidu jōga battudu katțina māneccidu $\bar{a} p \varepsilon$ (the possession by taking the sword is transferred to the one who is tying [gaggara or anii])'.

7 This ritual is called suriya pạdonuni.

8 During the ritual, only men can enter the precinct of Bantakamba. Women gather outside the Bantakamba and observe the ritual carefully.

9 The original meaning of vākụ piripuni is 'removing $\bar{a} j a$ '. Āja means that a person who disputes with one of his/her relatives makes a vow that his/her descendants will never contact with the descendants of the opponent. If the descendants break the vow, it is believed that a curse will fall on them. Vākụ piripuni is the ritual to abrogate the vow in front of deity and reconstruct the relationship between the relatives (see Upadhyaya 1988-1997, p. 2791).

10 This ritual is also called "kattu-kattuleda a avara (offering food according to the custom)'. 


\section{The transaction of wild śakti}

In the previous chapters, I have described the basic components of the experiential umwelt of the villagers in Perar, which is based on their relationship with the land, nature, and deities: that is, houses, ranks, and ritual organisation; the oral epics that narrate the history of butta worship; and the ritual process of the nēma. In this chapter, I will examine the transactional network formed performatively between the villagers and deities, focusing on their interaction in ritual processes. More specifically, I will mainly examine the following topics: the characteristics of the network formed through the interactions between devotees and bütas incarnated in mediums, the relationship between deities and villagers who participate in reciprocal transactions, and the circulation of forces and substances in the transactional network. Referring to previous studies on gift-exchange, substance-code, and personhood (Appadurai \& Breckenridge 1976; Marriott 1976; Marriott \& Inden 1977; Strathern 1988, 1996), I will investigate the ritual transactions between people and deities. In addition, referring to previous studies on purity, pollution, and śakti (e.g. Tanaka 1997; Sekine 2002), I will consider the features of the wild śakti circulating between deities and humans.

\section{Transaction, dividuality, and the network in South Asia}

In his essay 'Hindu Transactions: Diversity without Dualism' published in 1976, Marriott describes South Asian society as 'an elaborate transactional culture, characterized by explicit, institutionalized concern for givings and receivings of many kinds in kinship, work, and worship' (Marriott 1976, p. 109). He also proposes that South Asian personhood is characteristically 'dividual':

Persons - single actors - are not thought in South Asia to be 'individual', that is, indivisible, bounded units, as they are in much of Western social and psychological theory as well as in common sense. Instead, it appears that persons are generally thought by South Asians to be 'dividual' or divisible.

(Marriott 1976, p. 111) 
According to Marriott, dividual persons absorb various material influences and emit particles of their own 'coded substances'-essences, residues, or other active influences - to others. ${ }^{1}$ They engage in transfers of bodily substance-codes through parentage, marriage, provision of services, and other kinds of interpersonal contact. As a result, 'Dividual persons, who must exchange in such ways, are therefore always composites of the substance-codes that they take in' (1976: 111).

Around the same time, Appadurai and Breckenridge (1976) also published an article describing the personhood of Hindu deities and the 'transactional network' involving humans and deities. According to Appadurai and Breckenridge, rather than as a mere image or symbol, the deity in a south Indian temple is conceived of more as a person who is both sentient and corporeal (1976, p. 190). Through worship and offerings, devotees enter into an 'active transactional relationship' with the deity, which initiates a process of redistribution. The devotees conduct transactions with the deity as a 'special person':

At one normative level, the deity ... commands resources (i.e., services and goods) such as those which are necessary and appropriate for the support and materialization of the ritual process described above. But these resources are not merely authoritatively commanded and received by the deity. On receipt, they are redistributed in the form of shares ( paik $k$ ) to the royal courtiers, the donor (yajamāna), and worshippers at large. The authority to command and redistribute resources places the deity at the center of a transactional nexus in which the deity is expected to be generous. Ritual which constitutes worship provides the schematic and elementary unit in which to observe the transactional network where first the deity and subsequently the donor are the object of gifting activity.

(1976, p. 195; emphasis added)

As presented by Appadurai and Breckenridge (1976), this argument has close similarities to that of Marriott (1976). If Marriott's ideas of dividual personhood and substance-code are applied to the account of Appadurai and Breckenridge, it can be said that both the devotees and the deity are dividual persons engaged in the exchange of their substance-codes as 'gifts' for each other in a transactional network that enchains them. ${ }^{2}$ As we will see later in the case of büta worship, the substance-codes gifted by devotees to deities are offerings, while those given by deities are śakti and blessings, distributed among devotees in the form of prasāda (blessed offerings from the altar). On this point, Marriott (1976, pp. 110, 113) describes particles of substance-codes as constantly in circulation, just as power-present in various objects such as persons, gods, and land-flows everywhere. Thus, along with offerings, which are composites of various social relations, power circulates in transactional networks between humans and deities. 
Before we consider this point more closely, it is worth considering Strathern's ideas about how persons, hybridity, and networks are presented (1988, 1996). The notion of 'dividual persons' presented by Marriott in the 1970s has spread beyond South Asian social contexts, yet most discussions have focused on individual-dividual dichotomy issues, assuming correspondence with a dichotomy between Western and non-Western personhood, or have made cross-cultural comparisons of conceptualisations of the 'person' (e.g. Busby 1997; Rasmussen 2008; Mosko 2010; Smith, FM 2006; Smith, K 2012). As we will see below, by discussing the disposition of dividual persons in networks that both link and sever social relations, Strathern presents an original analytical lens beyond the cultural-relativistic view of personhood.

\section{Hybrid personhood in transactions, or how to cut the network}

Strathern (1988) notably applied Marriott's notion 'dividual person' in her analysis of Melanesian society. In The Gender of the Gift (1988), she wrote, 'Melanesian persons are as dividually as they are individually conceived ... Indeed, persons are frequently constructed as the plural and composite site of the relationships that produced them' (p. 13). Her remarks certainly recall Marriott's insistence that dividual persons are always composites of the substance-codes that they take in through transactions (1976, p. 111).

Later, in her 1996 essay 'Cutting the Network', Strathern elaborates her notion of the (dividual) person in Melanesia by applying the concepts of 'hybrid' and 'network' originally developed by actor-network theorists (e.g. Latour 1993; Warnier 1995). Using de Coppet's ethnography of the 'Aréaré of the Solomon Islands (in Barraud et al. 1994, pp. 40-65), Strathern illustrates the hybridity of humans in this society. According to de Coppet, the 'Aré'aré divide living creatures into three elements: body, breath, and image. Upon death, the person decomposes into these: the body, the product of others' nurturing, is eaten as taro; breath is taken away in the breath of slaughtered pigs; and the image becomes the ancestor (Strathern 1996, pp. 525-526). Strathern thus argues that the living human being is a 'hybrid' person and, moreover, each of the three components is also a person. ${ }^{3}$ She writes:

I use the term 'person' since the human being is also conceived as an aggregation of relations; it can take the form of an object available for consumption by those others who compose it. In these acts of consumption, the person is, so to speak, hybridized, dispersed among a network of others.

(Strathern 1996, p. 526)

Here Strathern's main concern, however, is not how a network composed of both human and nonhuman persons extends itself, but how its extension 
can be controlled or cut. In the Solomon Islands, shell money, which embodies the image of the deceased, plays an important role. In essence, an item of shell money has circulatory power because other entities, events, and products are converted into it: past encounters and relationships circulate in condensed form in its 'body'. At death, there is a finalising sequence of exchanges in which the two other components of the living human, body and breath, are converted into money (Barraud et al. 1994, pp. 53-54). The ancestor-image eventually encompasses the others, and the sequence stops at that point. 'Money thus becomes the repository or container of prior interchanges' (Strathern 1996, p. 526).

Strathern's close investigation of de Coppet's ethnography of the 'Aréaré (including marriage and kinship systems in Melanesia, which are beyond the scope of this chapter) yields several important axioms regarding hybridity and networks: the hybrid is an amalgam of social relations (Strathern 1996, p. 527); networks - either homogeneous or heterogeneous-constructed through transactions must have limits; and the protocols for creating networks of varying lengths have different capacities for sustaining, reversing, or stopping flow (pp. 523, 528-529). This analysis enables Strathern to identify a problem with the analytical networks of actor-network theory, which are basically regarded as limitless (1996, p. 523). Contrary to the network as conceived by some actor-network theorists, Strathern's network has a certain length and thus can be cut at some point. ${ }^{4}$

The above argument can be reconsidered from the perspective of the Gestaltkreis theory examined in Chapter 1: the transactional network is performatively formed through the interactions of both human and nonhuman actors; at the same time, it forms a cyclical circle, or Kreis, through the circulation of substances within the network. In other words, the transactional network describes its boundary through its motion, while it is performatively formed through the flow of substance-codes.

As we will see below, in būta worship in South Kanara, the transactional network which links humans, deities, and land and nature is formed through the circulation of offerings that embody the fertility of the land and blessings that manifest the wild śakti. At the same time, the network performatively creates the boundary which marks social as well as geographical borders. ${ }^{5}$ Moreover, through transactions of substance-codes, the participants of the transactional network (re)create their ways of being in relation to their human and nonhuman partners. Next, I will investigate in more detail the transactional network between the būtas and villagers in Perar.

\section{Ritual transaction, dividual persons, and the circulation of śakti}

First, I examine the kambula ritual described in Chapter 2, which is dedicated to the būtas and organised by the first guttu of Perar. By analysing the interactions between būtas and humans in the kambula ritual in terms 
of dividual persons, hybridity, and the network, I attempt to show how the circulation of substance-codes between the human realm and the wild is the flow of life itself, the basis of the villagers' lives.

As seen in Chapter 2, the whole ritual process can be understood as the circulation of būta śakti from the wild forests and hills (guḍḍ) to the cultivated field. The wild and fertile power of the deities, manifested in the buffalo būtas, is summoned by Subba. Through his invocation of the būtas in the butta territory of the wild mountain, Subba himself partly embodies their wild and fertile power. This power, concomitant with Subba's journey, first flows into the manjotti field and is distributed among the male members of the Manșa family. Then the power of the būtas, which is expressed in Subba (metaphorically) as well as in the living buffalo (metonymically), finally flows into the kambula field as the 'bride'. The kambula field is filled with the būtas' power, and later this power is transformed into the paddy in the field.

In this ritual, the power or substance-code of the buffalo circulates in the network, linking the wild with the agricultural fields. Hence, the buffalo can be regarded as a 'dividual person' who is involved in, as well as constitutes, the transactional network. Subba, as an interim priest, works as a medium, or carrier of the power, of the buffalo-büta-person. At the same time, his movements guide the flow of this power by leading it first into the manjotti, then into the kambula field, and finally into the young paddy, which he plants by hand. Correspondingly, at harvest time, Subba is the first person to cut the rice in this field. At this moment the büta's power, which had been transferred into the land and produced paddy, returns to the people through Subba. Here, Subba acts as 'both container and channel, blocking flow and bodying it forth' (Strathern 1996, p. 528). And the paddy produced in the kambula field can be understood as a hybrid composed of the wild büta sakti, human labour and service, and the kin relations of the first guttu family.

Next, focusing on the nemma, let us examine the process of the circulation and redistribution of the wild śakti personified in various forms such as human mediums, farm products, and prasāda.

As seen in Chapter 5, during the ritual, the devotees interact with the deities incarnated in the Banta priest and Pambada dancer-mediums. The most significant and repeated form of their interaction is the mutual gifting between the guttu heads and the deities. In the yearly ritual, the guttus offer the deities a part of their farm products such as paddy, coconuts, and areca nuts, which embody the fertile power of the deities, the labour and service of humans, and the social relations in the village. The deities receive and consume these offerings, ${ }^{6}$ and they in return give oracles and blessings to ensure the future prosperity of the whole village. Finally, some of the offerings are redistributed as prasāda among the devotees. Through this ritual process, concentrated in the farm products, offerings, and prasāda, the būta śakti flows and circulates in the transactional network, which is part of the more extensive network between humans and deities, as illustrated in Figure 6.1: 


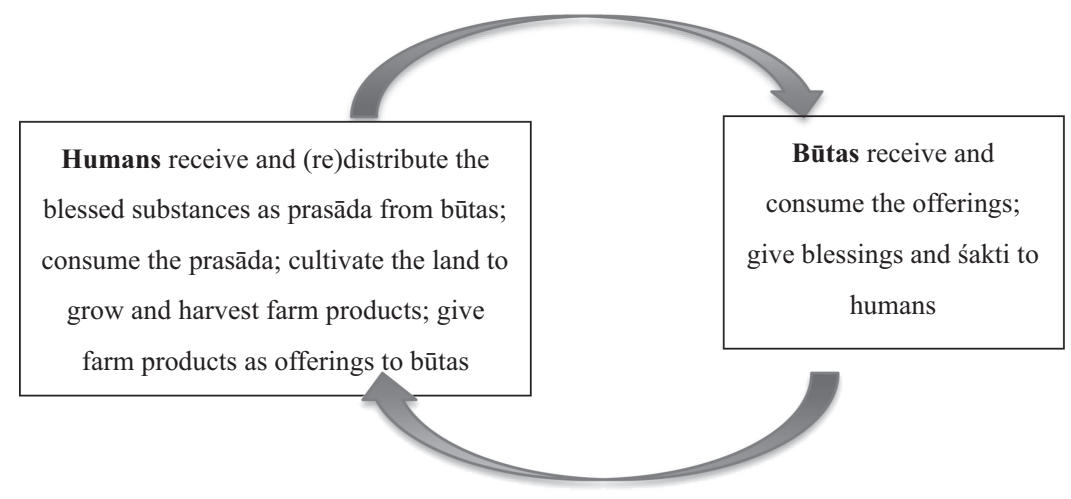

Figure 6.1 The transactional network between humans and būtas.

The farm products and prasāda, which embody the wild sakti and crystallise people's vital activities, are thus produced through the transaction between humans, deities, land, and nature; at the same time, they support and enable the reproduction of people's lives.

In these transactions, the offerings and their transformed substances, prasāda-regarded as the substance-codes of humans and deities, that is, hybrid 'persons' - are consumed and thus dispersed among the network (Strathern 1996, p. 526). Similar to the role of Subba in the kambula ritual, here the būta mediums act as carriers of the būtas' power, and at the same time, their movements induce and direct the flow of the substance-codes. Likewise, the būtas and devotees are regarded as dividual persons who exchange their substance-codes with each other; or to use Strathern's words, they act as the 'turning point for directing the flow of fertility back' (Strathern 1996, p. 528).

Both in the kambula and the nēma, the flow of substance-codes is primarily personified in and directed by the medium, the priest, or both. It is also noteworthy that the extension of the transactional network is limited by the rights and affiliations of both the humans and the deities (see Strathern 1996, p. 525). For the humans, the extension of the circulation and (re)distribution of substance-codes as prasāda is restricted to members who have the right and duty to enter into transactional relations with the deities (moreover, the flow and (re)distribution process of substance-codes is ordered according to the rank and sex of the participants ${ }^{7}$ ). For the deities, the extension of the circulation of substance-codes as offerings is limited to those deities worshipped by the main patrons of the ritual, that is, the bütas affiliated with or personifying the power of a particular house, plot of land, or guḍde. Therefore, for instance, in the ritual held at the family level, offerings are presented to the bütas affiliated with the family's land, and prasāda is distributed among the members of the family. Meanwhile, 
in the case of the nēma, offerings are presented to the deities enshrined in the village shrine, and the gadipatinārụ, the heads of the guttus, and other villagers responsible for the primary ritual services have priority regarding receiving prasāda.

Nevertheless, neither the extent of the transactional network nor the order of the distribution of substance-codes is permanent; rather, they are performatively formed through ritual practice. Therefore, as we will see in Chapter 8, the traditional order is often altered by new outsiders joining, and this results in disputes among the ritual participants. At the same time, as we will see in Chapters 8,12, and 13, by joining in a newly formed transactional process, a new ritual community can be created among people with various backgrounds and intentions.

From the above description, it is clear that the ritual transactions and flow of substance-codes in the transactional network performatively link the participants, both human and nonhuman, and at the same time set the boundaries separating the people according to their affiliations and the būtas according to their identification with particular territories.

The importance of the boundary or limit of the transactional network corresponds to the importance of the boundary of a person directly interacting with the deities. Namely, as we will see in Chapter 7, in the büta ritual, a Pambada medium transforms himself through an exchange of perspectives with a deity, while he strives to maintain his boundary as a person to avoid the complete loss of himself. In other words, how to maintain one's boundary as a person becomes a serious question, because one has to interact with others not as an autonomous individual, but as a dividual person (see Gell 1995; Laidlaw 2000, pp. 629-631). ${ }^{8}$

I will next investigate more closely the characteristics of the wild śakti, the most important substance-code circulating in the transactional network.

\section{Untamed śakti in the būta ritual}

\section{Wild śakti and ritual pollution}

As seen in Chapter 2, büta worship is deeply related to the forests and hills called guḍd $\varepsilon$, and some wild animals dwelling in the guḍde are regarded as higher-ranked būtas. Likewise, the wild sakti flowing in the guḍd $\varepsilon$ is the most important substance-code that circulates in the transactional network between humans and deities. I will first examine the characteristics of śakti in būta worship in terms of purity and pollution.

In previous studies on Hindu rituals in India, divine power or śakti has been uniquely related to the notions of 'purity' and 'pollution'. Namely, it is regarded that in the dualistic relation of purity and impurity, purity is endangered by impurity with contamination; meanwhile, sakti is transcendental and thus immune to pollution. ${ }^{9}$ In addition, śakti is regarded both 
as dangerous and as the fertile energy of a fierce goddess (see Uchiyamada 2000, p. 71; Fuller 2004, pp. 44-48).

A number of fundamental characteristics of būtas are inextricably linked to wildness and femininity, in a word, śakti. It is notable that in Tulu, śakti can refer to power, the existence of the supernatural powers of the būta, or the būta itself (Upadhyaya 1988-1997, p. 2834). That the bütas are believed to be the spirits of local heroes/heroines who met tragic deaths - or those of wild animals - contributes to this sense of danger and feral power. This is further connected to a feminine aspect of the būta, as in Perar, Balavāṇḍi is regarded as androgynous, and devotees offer beautiful saris to the deity. As these elements show, the bütas embody the strong, dangerous, and fertile śakti. In būta worship, then, what is the relationship between purity (madi or sudda), pollution (mayilige or asudda), and śakti? Yatish Pambada, the dancer-medium of Balavāṇdi in Perar, explained the rules he follows in terms of sudda:

We, as būta performers, should not eat food offered at a funeral. I strictly follow this rule. Apart from that, we should not eat food prepared by a woman who is menstruating. Also, we should not eat food in the houses of Ācāri, Catholics, or Muslims. Though it is not easy for us to obey all the rules (niyama) today, we try to be in a state of purity (sudda) as much as we can.

(Yatish Pambada, 16 June 2008)

Similarly, Jayānanda Pambada, the dancer-medium of Arasu and Pilicāmuṇụi, explained that every dancer-medium should strictly obey particular rules to invoke the butta in the ritual:

The būta performance is called nēma. This word originated from $n i$ yama [rules and regulations], in Sanskrit. Only when the performer obeys the rules, will it be successful. So, we should be in the condition of niyama niște [devoting oneself to the rule]. We should follow several ritual practices. For instance, I'm a strict vegetarian and I never drink alcohol. If you obey these rules, daiva will definitely come to you.

(Jayānanda Pambada, 16 May 2008)

As shown in these narratives, for both, the notions of niyama and sudda are crucial to being a proper dancer-medium. At first glance, their keen concern for the rules and purity seems to be evidence of the Sanskritisation of the Pambada dancer-mediums; they seem to adopt both Sanskritic notions and the Brahmanical doctrine, such as vegetarianism and asceticism, to raise themselves up to a higher position in the caste hierarchy (see Srinivas 1952, pp. 30-31). However, the notion of purity in the context of büta worship cannot be reduced to a dualistic model in which purity is opposed to an impurity that endangers the former with contamination. Rather, the notion of purity 
is closely connected with that of sakti, which is transcendental and thus immune to pollution. Jayānanda Pambada's comments on the relationship between the purification of a būta impersonator and ritual pollution provide a clue to understanding this point.

When a Pambada is selected as a būta impersonator, he should be purified by a Brahman priest. This ritual is called kalaśasnāna. After this ritual, he becomes immune to the pollution that occurs through either death or birth. He becomes free from them. Even if his father dies, he is exempt from sütaka [death-pollution].

(Jayānanda Pambada, 16 June 2008)

The most critical events regarding ritual pollution are death and birth. Death and birth bring a state of ritual pollution, called sūtaka and ame respectively, within a kuțuma (matrilineal joint family). If someone dies or gives birth in a kuțuma, all of the kuțuma members are regarded as being temporarily polluted, and thus they have to follow several taboos for a certain period. ${ }^{10}$ Purified by a Brahman priest, however, a Pambada dancer-medium does not have to take on the fundamental pollution of death and birth. While he has to keep himself away from these events, he is exempted from the ritual pollution which is automatically applied to all of the kuṭuma members.

The above issue helps us to understand the relationship of purity, pollution, and śakti in būta worship; after the purification ritual, a Pambada dancer-medium is enabled to access the śakti of the būta, and thus to obtain sacredness, which frees him from ritual pollution. ${ }^{11}$ Though he must keep himself pure and clean by obeying various rules, it is not his ultimate goal to attain a purity that is opposed to, and endangered by, pollution. In other words, as Fuller (1979, pp. 463-464, 469) argues about rituals in a Hindu temple, purity is not the end of the ritual but is only a means of accessing divine power. Thus, the purity of a Pambada dancer-medium should be understood as a necessary condition for him to invoke śakti within himself.

\section{Untamed śakti}

I will next investigate the dynamic circulation of śakti in the nēma in Perar, focusing on the interrelation between Balavāṇdi and Bramma. As already mentioned, śakti is generally regarded as the dangerous as well as fertile energy of a fierce goddess. It is not stable, but rather a dynamic flow of divine force (see Tanaka 1997, p. 13). Some previous studies on goddess worship in Indian and Sri Lankan villages have analysed the ritual as the process of the emergence and control of śakti. For instance, Tanaka (1997, p. 148) describes abhișeka (consecration rituals), in which sakti created in the fire is transferred to the sanctum sanctorum, the purest place in the temple, and finally taken into the village, as the transformation of divine power 
'from something hot, dangerous and wild, into "grace (the root meaning of prasāda in Sanskrit)"'. Similarly, focusing on a village ritual in Tamil Nadu, Sekine (2002) points to the mutually complementary relationship between god and goddess by describing the role of the Sanskritic god who tames the divine power of the fierce goddess. Here, their relationship is analysed not as a hierarchy based on the binary opposition of purity and impurity assumed by Dumont (1970, 1980), but as the dynamism of the active, creative śakti and its stabilisation. ${ }^{12}$

The above viewpoints of these previous studies are suggestive for considering the interrelation between Balavāṇdi and Bramma in the nēma in Perar. In the ritual, Balavāṇdi and Bramma are presented as contrastive deities to each other. While Balavāṇdi is an active, dangerous, and androgynous deity belonging to the realm of the wild, Bramma, as shown in the stable statue of the brammalinga, is regarded as static and masculine. In the nēma, Balavāṇdi, incarnated in Yatish Pambada, appears from outside the shrine as a half-naked, dangerous, and furious deity, dances around the precinct, and finally reaches the Bramma guṇụa. This movement of Balavāṇḍi visualises the flow of the wild sakti embodied by the deity.

As already seen, purity for the būta medium is not the same as a purity contrasted to impurity. Rather, it is regarded as the necessary condition to invoke śakti within oneself, which transcends the binary opposition of purity and impurity. Likewise, it is undeniable that the interrelation between Balavāndi and Bramma in the nēma also expresses not the simple opposition of impurity and purity, but the relation between sakti and something that is linked to it. In this ritual, however, the process in which the wild sakti embodied by Balavāṇdi is tamed by Bramma and transformed into graceful prasāda is nebulous. What is emphasised in the ritual is not the influx of a goddess's śakti and its transformation by a masculine god, but the battle of two powerful bütas. In this battle, however, Bramma never appears as himself except as the figure of the brammalinga; in addition, the Brahman priests serving at the Bramma guṇda never respond to Balavāṇdi incarnated in the dancer-medium. Therefore, the battle seems instead one-sided, with only Balavāṇḍi approaching.

Unlike the cases shown in the previous studies, the nēma ritual seems insufficiently structured. As we will see below, this is due to the unique features of the relationship between Bramma and Balavāṇḍi, and also the relationship between the devotees and būtas, or the wild śakti. As already mentioned, Bramma is often identified as the Hindu god Brahma, and in the village shrine in Perar, only Bramma is served by Brahman priests. At the same time, Bramma occupies the position of supreme būta. Despite being enshrined in a temple-like guṇụa and being offered special rites by Brahman priests, Bramma is still distinct from the Sanskritic Hindu god. Here, one cannot find the systematic ritual structure through which the Sanskritic masculine god receives and stabilises the goddess's śakti. 
Although Bramma has features of a stable and masculine god, it is also a powerful and dangerous būta embodying wild śakti (see Claus 1978, pp. 4-10). Therefore, the interaction between Bramma and Balavāṇdi in the ritual expresses not the process of the influx of dangerous śakti and its stabilisation, but rather the influx, overflow, and struggle of śakti. In the ritual process, divine śakti is not fully stabilised but circulates with threatening features of the wild, and then is directly received by devotees in its 'raw' state. As seen in Chapter 5, the interaction between devotees and deities includes not only the reciprocal exchange of offerings and blessings, but also the fearsome būtas' expressions of ire and their mollification by the devotees. This also shows that the bütas' power emerges in the ritual as the dangerous, untamed, wild śakti itself.

Although Bramma partially takes on the role of transforming the wild śakti into safer grace, this is not completed in the ritual. Instead, the uniqueness of būta worship not fully subsumed under the Brahmanical ritual-i.e. people being able to directly interact with the dangerous and fertile śakti without the mediation of the Sanskritic god-is preserved through this incompleteness of the calming of the wild śakti.

As seen in this chapter, the nēma in Perar has the basic structure of an influx of sakti from the realm of the wild and its distribution as prasāda among the devotees. The core of the whole ritual, however, is not the taming of śakti by a Sanskritic god, but the direct interaction between the devotees and the divine śakti. It is also a process of gift-exchange between humans and deities, which includes not only positive but also negative elements such as fury, curses, fear, and appeasement. For the devotees, therefore, the būta ritual is the means of receiving blessings and grace from the deities, and at the same time, it is an attempt to interact with the dangerous śakti in order to mediate the human realm and the wild realm. I will consider this issue in more detail in Chapter 13, focusing on the büta worship in an industrial plant.

The centrality of wild śakti shown in ritual practice, however, cannot be observed in the physical structure of the village büta shrine, in which the Bramma guṇa is centred. As we will see in Chapter 8, this issue became the critical question in a trial pitting the first guttu family against the Brahman priest. Before considering this issue in detail, I will examine in the next chapter the mutual interaction between humans and deities, focusing on the experiences of the būta mediums.

\section{Notes}

1 On the concept of 'substance-code', Marriott writes:

Varied codes of action or codes for conduct (dharma) are thought to be naturally embodied in actors and otherwise substantialized in the flow of things that pass among actors. Thus the assumption of the easy, proper separability of action from actor, of code from substance ... is generally absent: code 
and substance ... cannot have separate existences in this world of constituted things as conceived by most South Asians ... Before one begins to think of Hindu transactions, one thus needs firmly to understand that those who transact as well as what and how they transact are thought to be inseparably "code-substance" or "substance-code"

(1976, pp. 109-110; emphasis added).

On the issue of the self and personhood in South Asian societies, see also Marriott and Inden (1977), Daniel (1984), Busby (1997), Sax (2002), and Carsten (2011).

2 On gift-exchange in Hindu society, see also Parry (1986) and Raheja (1988).

3 In other words, as Parry (1986, p. 457) writes in his interpretation of The Gift (Mauss 1990 [1950]), there is no absolute disjunction between persons and things.

4 Strathern also argues, 'If we take certain kinds of networks as socially expanded hybrids then we can take hybrids as condensed networks. That condensation works as a summation or stop' (1996, p. 523).

5 Concerning the issue of the circulation and boundaries of substance-codes, arguments on landscape and topology are suggestive. See, for instance, Munn (1996) and Uchiyamada (1999, 2000).

6 Regarding the consumption of offerings by the butas, after the ritual for Pilicāmuṇụi inside the precinct is complete, the deity is offered both vegetarian offerings and blood sacrifices right outside the shrine building.

7 For instance, in the ritual held at the family level, first the head of the family and other male members receive the prasāda and then it is distributed among the female members of the family.

8 As seen in this chapter, one of the methods of maintaining the boundary in gift-exchange is to restrict who can participate in the transactional network and limit the circulation of substance-codes. Another possible way is to refuse to form the social relationship based on gift-exchange by keeping the gift as 'pure gift' or by impersonalising it. See Laidlaw (2000) and Copeman (2005).

9 On the notions of purity, impurity, and śakti, see Dumont and Pocock (1959), Harper (1964), Wadley (1977), Fuller (1979), Tanaka (1997, pp. 10-14, 138-139), and Sekine (2002).

10 If someone dies inside a kuțuma, the kuțuma members should not enter temples or shrines, and should not conduct any auspicious rituals for 16 days. The ritual pollution brought by death or birth is purified by a ritual called sudda malpuni, in which a Baṇ̂āiri (barber) man takes on the role of priest.

11 This is the case in purification rituals in Sri Lankan Tamil society presented by Tanaka (1997, p. 138). According to Tanaka, priests wearing a sacred kāppu cord containing mantra śakti become immune to death pollution.

12 On the complementary relationship among Hindu deities, see also Fuller (1988) and Ishii (2015a). 


\section{$7 \quad$ Playing with perspectives}

In the previous chapter, I explored the formation and dynamism of the transactional network between villagers and deities. In this chapter, I will now focus more narrowly on spirit possession, investigating in more detail the relationship between people and bütas. Rather than following the extensive circulation of substance-codes such as offerings, prasāda, and śakti, I will examine the intangible corporal experiences involved: the experiences of the büta mediums who receive divine śakti, and the experience of the devotees who interact with the deities.

First, it is helpful to elaborate this point in terms of jōga and māya, which were examined in Chapter 1. I focused in Chapter 6 on the question of how wild śakti, which flows from the realm of māya into the realm of jōga, is transformed into other substances and distributed among the people. In this chapter, I will instead focus on the space and time of spirit possession, that is, the borders of the realms of jōga and māya, to understand the art of the büta mediums who manifest the wild sakti by becoming the deities while remaining in the ambiguous, liminal state of possession. I will also investigate from the viewpoint of perspective exchange how the devotees and büta mediums interact with each other and mutually form their selves.

As we will see below, spirit possession has often been analysed in terms of the permeability of the self. At the same time, the idea of perspective exchange has become a key issue in studies on 'new animism' (see Pedersen 2001). ${ }^{1}$ Moreover, the issue of the transformation and reflexivity of the self, which is the crucial question in spirit possession and perspective exchange, is not only key to understanding the experience of the possessed, but also suggestive for understanding how people form their self and their umwelt through interrelation with others. Below, I will first examine several studies which analyse spirit possession in terms of the permeability of the self. I will then overview the studies on perspective exchange between human and nonhuman beings. Based on these previous studies, I will consider the exchange of perspectives between humans and deities in būta worship. 


\section{Spirit possession and the permeable person}

Spirit possession has often been analysed in terms of perspective and its alteration. Kapferer $(1979,1991)$, based on Mead's (1962 [1934]) argument on the construction of the self, studies demonic possession in Sri Lanka as the disruption of reciprocal perspectives between the possessed self and healthy other. Kapferer then describes the exorcism as the process of reconstructing one's intersubjectivity. By contrast, Boddy (1988, p. 19; 1989, pp. 350-351) analyses the $z \bar{a} r$ possession in Sudan as an occasion for the possessed to achieve a broadened perspective, which enables her to see the world 'with the eyes of the spirit', to transcend her everyday reality and herself.

Some scholars focus also on the concept of permeability to comprehend spirit possession. Boddy defines possession as

a broad term referring to an integration of spirit and matter, force or power and corporeal reality, in a cosmos where the boundaries between an individual and her environment are acknowledged to be permeable, flexibly drawn, or at least negotiable.

(1994, p. 407)

In the same manner, Keller insists that it is necessary to revalue 'receptivity and permeability beyond the usual, negative associations of such openness with passivity and weakness' $(2002$, p. 9$)$ in order to interpret the agency of the possessed.

These arguments show that spirit possession has been regarded as a phenomenon concerning foremost selfhood and its shifting or fluid boundaries. This theme of shifting the boundaries or of a metamorphosis of the self in relation to the other closely relates to the notion of mimesis: the human faculty to 'yield into and become Other' (Taussig 1993, p. xiii).

Studies regarding spirit possession as mimetic practice tend to focus on its critical function. Stoller (1995), using Benjamin-Taussig's notion of 'mimetic faculty' (Benjamin 1966, pp. 96-99; Taussig 1993), describes Hauka possession in West Africa as the tactics of the colonised to mimic the colonisers in order to divert their power and to master them. Rosenthal (1998, pp. 75-76, 95-97) analyses Gorovodu possession in Togo as a mimetic ritual which manifests commentaries on 'modernity'. In a broader context, Boddy argues that the notion of mimesis enables us to recognise 'the multidimensioned resistances possession cults evince to Enlightenment myths of context-free Reason, the mischief they work with capitalist reifications, their iconoclastic interpretations of commodities and bodily disciplines' (1994, p. 425). Thus, spirit possession characterised by perspective alteration, permeability, and mimesis has been analysed as an 'embodied critique' (Boddy 1994, p. 419) of modernity, colonialism, or global political and economic domination.

This understanding of spirit possession as the critique of modernity and other hegemonies corresponds to a view that distinguishes the possessed self 
from the ideal modern Western self. Here, the studies on spirit possession link with those on self and personhood. For instance, Smith (2006, pp. 19, 74-75) points out that Boddy's (1994, p. 407) definition of spirit possession, as the exposure of the fluid and permeable nature of personal identity, coincides well with the features of South Asian personhood, which is fluid, divisible, and permeable. The possessed person or the South Asian person is described in contrast with the ideal Western, 'impermeable, autonomous person' (Marriott 1976, p. 110, quoted in Smith 2006, p. 74).

Pointing out the critical function of spirit possession and also highlighting the fluid and permeable characteristics of the possessed, some of these approaches have effectively posed alternatives to the "possessive individualism' of the West (MacPherson 1964, quoted in Johnson 2011, p. 417). ${ }^{2}$ At the same time, by attributing these characteristics specifically to the possessed, this vein of argument has alienated from ordinary human experience the experience of the possessed as well as the permeable, mimetic status of one's being. ${ }^{3}$

However, as Boddy (1994, p. 425) partly admits, mimesis, permeability, and perspective alteration are all integral parts of one's being in relation to others. In this sense, the possessed may be those who best exercise the mimetic faculty as 'an inherent part of the human condition' (Willerslev 2007 , p. 9). Still, as we will see later, the possessed person is not so permeable as to lose his self completely, just as the 'modern' person is not so impermeable to let nothing enter into her self.

To deepen the investigation into permeability, mimesis, and self-alteration in spirit possession, it is beneficial to consider a number of studies on perspective exchange, which extensively discuss comparable issues. Though there are various arguments on this subject, mainly in the fields of developmental psychology, phenomenology, and philosophy, ${ }^{4}$ here I focus on the anthropological discussion of perspectivism.

\section{The exchange of perspectives between humans and nonhumans}

In his article 'Cosmological Deixis and Amerindian Perspectivism', Viveiros de Castro (1998) presents perspectivism as the key concept characterising the human-nonhuman relationship in Amazonian societies. According to indigenous Amazonian theory, animals and spirits regard themselves as people, while they perceiving humans as the spirits or animals. Every animal species possesses a soul or spirit; hence, they are conscious subjects capable of having their own point of view. Or rather, in the context of Amerindian perspectivism, it is more accurate to say that this point of view creates the subject. Though animals see things in an analogous way to the way we do, each species sees different things because every species has its own bodily uniqueness and ways of being that constitute a habitus (Viveiros de Castro 1998, pp. 470-472, 476-478).

Focusing on shamanism and warfare in Amerindian societies in a more recent article, Viveiros de Castro (2004b) advances his argument on 
perspectivism. Here, he not only points out the difference of perspectives among the species, but also considers the exchange of perspectives between humans and nonhumans, between self and other.

According to Viveiros de Castro, shamanism is the capacity to cross ontological boundaries and adopt the perspective of nonhuman subjectivities. It is also a form of acting that presupposes a mode of knowing: knowing the object by personifying it and taking on its point of view. Shamans can turn into nonhumans such as animals and spirits and see them as they see themselves. But this act also entails risk. If ordinary humans happen to see a nonhuman in human form, they may be overwhelmed by the nonhuman subjectivity and be transformed into an animal or a spirit. Thus for Viveiros de Castro, a 'meeting or exchange of perspectives is, in brief, a dangerous business' (2004b, p. 468).

Similar to shamans, warriors are also engaged in the dangerous business of exchanging perspectives with their enemies. In the same way that the shaman turns into an animal to acquire its perspective, the warrior must become his enemy to apprehend him from the inside. By gaining the enemy's perspective and seeing himself as the enemy sees him, the warrior can become himself as a full subject. This kind of enmity is 'a reciprocal subjectification: an exchange, a transfer, of points of view' (Viveiros de Castro 2004b, p. 479).

Viveiros de Castro's arguments on perspectivism have had a great influence on recent anthropology and have evoked much discussion. ${ }^{5}$ Through examinations of his ideas from various angles, some scholars have tried to present alternative understandings of perspective and its alteration. For example, Turner (2009) calls attention to the social, relational, and alterable aspects of the human body, which play a fundamental role in perspective transformation. Finding vestiges of structuralism in Viveiros de Castro's arguments, he claims that Viveiros de Castro's perspectivism characterises perspectives as fixed aspects of species identity, like synchronic signifieds abstracted from discourse. Against this, Turner argues that perspectives are rooted in the synthetic social and physical body, such that they can be transformed along with the transformation of the body, which is integrally and socially connected to other bodies. According to Turner, the body 'is not an abstract object with a fixed, culturally human perspective, but a process comprising a series of transformations, each of which entails a transformation of perspectives' (2009, p. 30).

Here, Turner presents a clearly different understanding of perspective transformation from that of Viveiros de Castro. Although Viveiros de Castro also surely considers the transformation of both body and perspective, he mainly deals with the drastic and total interchange of one set of bodyperspectives with another; for example, a shaman shifts into animal form to assume its perspective, and then reverts to his human body-perspective. By contrast, Turner focuses on the more gradual or generative transformation of the body itself, which is accompanied by perspective transformation. ${ }^{6}$ 
Before considering this issue in detail, however, let us examine Willerslev's argument $(2004,2007)$ on hunter-prey relations and perspective exchange among Siberian Yukaghirs. According to Willerslev, in the world of the Yukaghirs, persons can take on a variety of forms such as trees, spirits, and mammals, of which human beings are only one type. Humans and animals can move in and out of different species' perspectives by temporarily assuming alien bodies. Among the Yukaghirs, 'this capacity to take on the appearance and viewpoint of another being is one of the key aspects of being a person' (Willerslev 2007, p. 2). It is their faculty for mimesis, Willerslev argues, which allows the Yukaghirs - especially hunters - to be similar to other species.

To lure and kill his prey, a hunter imitates its behaviour. Through this mimetic practice, he can assume the animal's point of view to exercise critical power over it. However, this is dangerous for the hunter because he may lose his original identity and undergo an irreversible metamorphosis (Willerslev 2004, p. 629). To avoid this risk, the hunter must retain his self-awareness during his mimetic practice. Even if he behaves as an animal to gain its perspective, he still has to maintain his identity and a kind of 'depth reflexivity' to be able to turn back into himself. Willerslev calls this state of the hunter's consciousness a 'double perspective'. Taking on an alien body, therefore, does not imply the full identification of a person with the other but a 'partial one' (Pedersen 2001, p. 416). It permits the person to act in between identities. It also gives him 'a new potential for action, as he is freed from the bodily limits of both his own species and those of the species imitated' (Willerslev 2007, pp. 95-96).

While arguing the significance of perspective exchange for the Yukaghirs, Willerslev points out the danger of a total exchange or fusion of perspectives and emphasises the importance of retaining reflexive self-awareness amid perspective exchange. Similar to Boddy (1988) and Keller (2002), here perspective, subjectivity, and identity are considered not as the fixed, stable, or intrinsic foundation of a person but rather as a vulnerable condition that can easily be transformed, eroded, or dissolved. ${ }^{7}$ Willerslev's argument is distinctive, however, in its focus not only on the permeable aspect of the self, but also on the indispensability of reflexive self-awareness for the protection of the self from total erosion.

This corresponds to the argument in the Gestaltkreis theory regarding the integrity and transformation of an organism as the subject. In his argument on the crisis of an organism, von Weizsäcker points out the importance of the self-referential function of perception for maintaining its homeostasis: that is, not taking the alteration of the self seriously (1997, p. 109; see also Blankenburg 1991, pp. 106-109). As we will see below, this issue of perspective exchange and self-reflexivity is important for understanding the experience of the būta mediums.

Nonetheless, Willerslev's argument cannot fully grasp the possibility of people not only switching their perspective momentarily but also transforming themselves through the continual experience of perspective exchange, since Willerslev stresses the protection and recovery of one's original identity. 
In other words, when a hunter returns to the encampment from the hunt and turns back into himself, can he turn back into exactly the same self? Or rather, has he not been altered by his experience of exchanging perspectives with his prey? This latter possibility suggests that the hunter enters into a gradual process of transformation to become a 'real' or 'better' hunter/human in relation to his prey: he modifies his embodied perspective and his self accordingly to suit the social relations with his intimate other-his prey. To consider this possibility is to consider the reflexive and alterable aspects of one's self, body, and perspective. ${ }^{8}$ In the next section, I will inquire into this issue focusing on the relations between deities, mediums, and devotees in būta worship.

\section{The mimetic art of būta mediums}

As seen in Chapter 3, the roles of the büta dancer-mediums are hereditary, played by the male members of a Pambada family living in the village. Among the Pambada family in Perar, two youths - Jayānanda and his second cousin Yatish Pambada-play the central role as the dancer-mediums of the three main būtas: Balavāṇḍi, Arasu, and Pilicāmuṇḍi. They have succeeded the profession and role of butta dancer-mediums from their fathers, who were also prominent dancer-mediums. Yatish narrated his story of becoming Balavāṇdị's dancer-medium in Perar this way:

Following my father, I started this profession when I was 11 years old. At that time, I performed only small deities and not great daiva [the honorific name for būtas]. Here, in our village, I started to perform Balavāṇḍi after my father died two years ago ... This means that this profession is hereditary. An outsider cannot be the performer of these daivas.

(Yatish Pambada, 16 June 2008)

According to Jayānanda, he started his profession as a būta dancer-medium when he was 12 years old. At the beginning, he performed a būta called Bavano, who is an assistant būta of Pilicāmuṇịi. When he was 15 , he started to perform one of the rājanụ daiva (kingly būtas) with the help of his father. $\mathrm{He}$ narrates the succession of his profession as follows:

Yes, I have inherited this tradition from my father. But it was already in my blood too, as we belong to the community of performers. For example, you don't need to teach a frog to swim; it swims on its own. Just like that, in some places, it comes spontaneously through the power of the daiva. Sometimes my father gave me some hints or knowledge, and our own observation also helps us ... When I was a child, I observed my father performing various daivas. After several years, I performed the attendant deity, following the rājanụ daiva performed by my father. This helped me to learn [the performance].

(Jayānanda Pambada, 16 May 2008) 
Like Yatish and Jayānanda, most boys born in the Pambada family frequently attend būta rituals with their close male kin. They take on various small tasks such as tearing coconut leaves into shreds to make the performer's skirts, holding up a mirror when the performer is making up his face, or fanning the performer after his performance. Through these various minor tasks, these boys learn the techniques of ritual preparation and its process, the dance and păddana of each būta, and the mode of communication between būta and devotee. Some of them make their debut as an attendant būta as young as ten years old.

As Jayānanda pointed out, the art of the būta dancer-medium is gradually acquired by a candidate through his observation and practice of the performance among his kin. In this sense, it can be considered that the art is acquired first through copying another's performance; a young candidate begins by mimicking the performance of his father, brother, or paternal uncle to learn how to behave as the būta dancer-medium, and, furthermore, as the deity itself. Through this mimetic practice, he also learns how to relate his bodily self to others on the ritual stage, for example, to the heads of the guttus, the mukkāldi, the musicians, and other ritual workers. In other words, he gradually modifies his perspective to relate himself to the other actors in the ritual. We will return to this issue later. ${ }^{9}$

\section{Multiple mimesis and the gift of being possessed}

To become a būta dancer-medium is, first of all, to learn how to mimic the deity and assume its perspective - just as to become a hunter among the Yukaghirs entails learning how to mimic an animal to assume its viewpoint. However, contrary to the Yukaghir hunter, who directly imitates his prey's behaviour, the büta dancer-medium does not mimic directly what are believed to be bütas, such as the wild tiger or serpent. Rather, the candidate imitates another performer impersonating the deity to assume this perspective. In this sense, for the būta dancer-mediums, taking on the deity's behaviour and perspective is the mimesis of mimesis, or double mimesis. However, if we examine their mimetic practice more carefully, we soon realise that it should be characterised rather as multiple mimesis: the senior dancer-medium, whose performance the candidate imitates, must have also acquired his art through mimicking his senior, who was in turn also mimicking another performer. Thus, the performance of a dancer-medium is possible through a chain of multiple mimetic practices in which the deity is regarded as the always-implicit prototype. Here, the dancer-medium's perspective inevitably assumes the multiple perspectives of the other mimicking the other mimicking the other, and so on, as when a person sees the reflections of reflections of reflections in two opposing mirrors.

At the same time, for experienced dancer-mediums, the deity exists not only as an imaginative prototype far beyond their mimetic practice, but as the actual power, or śakti, which comes over their bodies through spirit 
possession. Most Pambada dancers, moreover, assert that without incarnating the deity's power, their performance cannot be successful. In this sense, the art of the butta dancer-medium consists not only of the active ability to imitate another performer to acquire his perspective, but also of the passive capability of being possessed by the deity and being given its perspective. This capability or gift, however, cannot be acquired by the medium's intentional practice alone, but rather can only be given by the grace of the deity.

In other words, through his relation with others in the realm of joga, the būta medium remoulds himself, and at the same time, he opens his corporeal self and receives the divine śakti from the realm of māya, which enables him to transform himself into the deity. This way of being of the büta medium shows the pathisch aspect of human life that is inevitably related to the realm of māya.

As seen in the previous chapter, in order to receive this divine favour, the dancer-medium tries to keep himself in the state of niyama nișț (devoting oneself to the rules), the ideal condition from which to invoke the deity's power. As the deity's partner in the sacred transaction, he is very much aware of the circulation of his substance-codes, limiting them in order to temporarily transfer his body into the deity and achieve its perspective.

From this discussion, it is clear that the büta dancer-medium first acquires his art through a chain of mimetic practice within his community and that thus both his art and his perspective inevitably assume a certain degree of multiplicity. At the same time, however, his art is incomplete unless he has the capability of being possessed and receiving the deity's power. It is only through the simultaneously active and passive ability to relate oneself to other people and deities that the büta medium can take on the deity's perspective. $^{10}$

\section{Playing with perspectives}

How, then, do the butta mediums realise their experience of incarnating the deity's power and assuming its perspective? Here I consider this question by focusing on the experiences of the Pambada dancer-mediums and the mukkāldi.

According to Jayānanda Pambada, the deity possesses him momentarily, while its power remains longer in his body to vitalise it.

The daiva enters my body only for a while. This is called, in Tulu, mukkālu müji galige [for three seconds]. However, the power of the deity remains for hours. It's just like charging a battery. It takes a short time to charge it, but its power lasts long. Or, it's just like the first rain. Receiving the first rain, dried land sucks up all the water. But in the rainy season, the ground does not suck water and it just flows into the river.

(Jayānanda Pambada, 8 June 2008) 
By contrast, Yatish Pambada expresses his experience of being possessed as $\bar{a}$ karșanc, the moment of divine fascination.

YATISH: At the moment [of being possessed], my consciousness concentrates totally on the daiva. This is the moment of âkarșaṇe. For about three seconds, my soul goes to the daiva ... Then I recover my senses enough to be able to distinguish people.

ISHII: During the ritual, you have to call every guttu's family name in order. ${ }^{11}$ If you were to make a mistake with the order, it would create major problems. If you lose consciousness, how can you remember this order? YATISH: No, by that time, I have already recovered my senses. After ākarșaṇe, a time of śänta svabhāva [the calm state of mind] will come. When people chant prayers and throw petals and grains on me, I receive $\bar{a} v e \bar{s} a$ [spirit possession]. ${ }^{12}$ After that I know what to do next.

(Interview with Yatish Pambada, 16 June 2008)

Lastly, Bālākrishna Shetty, the mukkāldi of Balavāṇdi, describes the alteration of his bodily senses caused by spirit possession this way:

BĀLĀKRISHNA: The moment the daiva enters into my body, I can't see other people at all. It lasts for only a few seconds though. After that I recover my consciousness, but the power of the daiva still remains in me. Because of that, I sometimes feel unusually fierce anger. Balavāṇdi especially is always angry. When the daiva enters my body, a bodily alteration occurs. I feel my hands and feet become stiff, and my stomach fills with gas. My face also changes.

ISHII: After you have passed the power to the Pambada, ${ }^{13}$ can you free yourself from these feelings?

BĀLĀKRISHNA: Here in Perar, from the flag hoisting until its lowering ceremony [from the start to the end of the nēma], we don't know when Balavāṇdi will come to us. I can be possessed anytime. Even when Balavanụdi possesses the Pambada, he can suddenly come to the mukkāldi. That is the speciality of this place.

(Interview with Bālākrishna Shetty, 2 July 2008)

As shown in these narratives, for the būta mediums, spirit possession is experienced for only a few seconds. When the deity enters his body, the medium is totally fascinated by its power. Though he soon recovers his senses, he is still overflowing with the deity's energy, which enables him to behave as the deity throughout the entire ritual. Thus, in order to behave as the deity in the ritual, the medium must first let the deity enter his body and then recover from the captivation to work his reflexive awareness to 'know what to do next'. Contrary to our common supposition about spirit possession, it is not always the case that the medium is completely overwhelmed by the deity's power and loses himself; rather, he should experience the doubleness of being both the deity and himself. In other words, the medium incarnates 
the deity's power in himself and yet keeps his self-reflexivity in order to activate both his and the deity's perspectives together. This corresponds to the Yukaghir hunter's double perspective, which enables him to retain his depth reflexivity while assuming the other's viewpoint (Willerslev 2007).

As noted, the art of the büta medium consists of both active and passive aspects. This art is acquired practically through the mimesis of an intimate other, and at the same time it is gifted only by divine favour. This gift for being possessed, however, is not purely a blessing; it can also be dangerous for its recipient. As illustrated in Bālākrishna Shetty's narrative, the medium cannot foresee how or when the deity will possess him. It suddenly comes over the medium regardless of his will and forces him to alter his bodily senses, sentiments, and perspective. Therefore, the ultimate art of the buta medium is that of accepting the new perspectives which unexpectedly appear to him, activating them, and playing with them without being totally absorbed into them. In other words, it is the art of letting various perspectives - of the self, of the other performers in the chain of mimetic practice, and of the deitiesplay among themselves through his self, and yet doing so self-referentially. ${ }^{14}$ It is also the art of manifesting the divine śakti through his body, while remaining on the border of the realms of jōga and māya.

How, then, does the būta medium transform his perspective as well as his self through the continual experience of mimicking and becoming the deity? To consider this question, it is necessary to examine the relation not only between the deity and the medium, but also between the medium and the other devotees in the ritual. The next section explores the medium's transformation through these ritual transactions as well as his self-modification.

\section{Ritual transaction and the transformation of the self}

In the nēma, the būta dancer-medium must first prepare for his performance by breathing a prayer in front of the deity's altar. He then puts on his make-up, a special garment, anklets, and other ornaments. His make-up and garments indicate the particular deity he is going to perform. Through this process of dressing himself, the dancer-medium gradually prepares his bodily self to become the deity, and, at the same time, to be identified as the deity by others. This process can be considered as the transformation of his social body (Turner 1995, 2009), which is inevitably accompanied by a certain degree of vitalisation or alteration of his bodily senses. Jayānanda explains the necessity of the visual, auditory, and olfactory factors for the būta performance as follows:

The most essential things for the performance are rüpa, rasa, and gandha. Rūpa denotes the garments of the daiva: make-up, a red smock and trousers, tiri [a skirt made from coconut leaves], anklets, silver headgear decorated with flowers, and ani. All of them are a part of the rūpa and they are very important for the performance. Rasa refers to the instruments and songs (vādya saingitta). Drumming is indispensable 
for the performance. Gandha means the scent of flowers and sandalwood paste ... The ritual becomes meaningful only when these things are completely present. If they are present, the daiva will spontaneously come into the performer's body.

(Jayānanda Pambada, 16 May 2008)

The performer's social body is transformed from his mundane form into divine form by means of the ritual circumstances and paraphernalia. Above all, he is performatively transformed into the deity through the ritual transactions with the other participants.

As seen in Chapter 5, the most important transaction is the one with the gadipatinārụ. In the first stage of the ritual, called the gaggara decci, the gadipatināu chants a prayer to summon the deity into the medium's body. His body begins to shake at the moment the gadipatinārụ offers the prayer, and then the other guttu heads throw rice and flowers on him. The dancermedium possessed by the deity (hereinafter referred to as the deity-medium) dances around the precinct and greets the head of each guttu. The next stage is the recitation of the pạddana by the deity-medium in front of the thousands of devotees thronging the shrine. In the third stage, called the nēma decci, the deity-medium speaks oracles and then receives a tender coconut from the gadipatinārụ, pours its water on the floor, and gives it back to the gadipatināru with blessings. At the end of the ritual, the deity-medium touches the hands of each guttu head with his sword and gives them blessings.

In this ritual transaction, the gadipatinārụ always accompanies the deity-medium in order to respond to his every act as a representative of the devotees; at the same time, the deity-medium needs the presence of the gadipatinārụ so that through their interaction he can make his divine power conspicuous to all the devotees. They are thus in a dialogical and reflexive relation, which demonstrates the 'ideal' behaviour of the deity and the human in relation to each other.

This ritual transaction allows the devotees to form a link between the realm of joga - their experiential umwelt - and the incomprehensible realm of māya. It also constitutes and substantialises the social relations between humanity and the deities (cf. Appadurai \& Breckenridge 1976). This does not necessarily mean, however, that humans and deities or their 'worlds' exist prior to their ritual transaction. Rather, they performatively come into existence through the process of ritual transaction.

Through the verbal and physical communication with the deity incarnated in the medium, as exemplified in the interaction between the gadipatināru and the deity-medium, the people come to partially assume the deity's perspective, which remoulds their perspective from mundane to divine: the people transform themselves into beings related to the realm of māya. In the same manner, the medium also assumes the people's perspective through ritual transaction: he sees himself as the deity in their view, and thus transforms his perspective into that of a deity related to the realm 
of jōga. Through ritual communication and transactions, each actor learns and re-learns how to behave and relate him- or herself to the other, and modifies his or her perspective in relation to the other.

At the same time, it is notable that even though the medium performatively becomes the deity in the course of ritual transaction, he is not completely subjectified as the deity. Rather, as an expert medium, he keeps his self in a reflexive and permeable state through which multiple perspectives appear, act, and play among themselves. In this sense, the whole ritual is primarily designed not for the subjectification of the medium and devotees, but rather for introducing the divine perspective into the everyday human world and activating it in order to decentralise, shake up, and estrange the latter, if only temporarily.

As we have seen, the būta medium undergoes perspective transformations at various levels and for various durations. He transforms his perspective by mimicking other performers, altering his social body, communicating with ritual participants, and being possessed by the deity. It is through these complex and generative processes of perspective transformation that a person comes to acquire the art of incarnating the deity: that is, the art of entering into the other, and at the same time letting the other enter into oneself, without totally losing one's self. The self here, however, is not a subject obtaining an immanent viewpoint and voluntarily switching it to another, but rather a reflexive state or condition through which a person is able to let various perspectives come and go. In other words, it is the art of remaining on the edge of the realms of jōga and māya, avoiding being overwhelmed by the force of the metamorphosis while nonetheless manifesting the passivity of one's self. For the būta medium, niyama niște is thus the manner in which he modifies his self to be in the right condition for the deity to come and play through his body.

I have investigated in this chapter the experiences of the buta mediums and the devotees who exchange perspectives with the deities in the ritual. The relationship between people and deities, which is revealed through spirit possession, forms the basis of the transactional network and also generates the actuality of the divine sakti circulating within it. Through the experience of gazing at the deity incarnated in the medium and responding to her words and actions, the devotee partially undertakes the deity's perspective and also remoulds his/her own perspective in an umwelt that embraces the coming and going of butas. Moreover, while remaining in the realm of jogga, one nevertheless perceives the incomprehensible wild śakti and attempts to tune his/her life to it. For each devotee, this means learning the way to become a person related to the divine sakti that fills the realm of māya and momentarily manifests itself as the deity in the realm of jōga.

This mutual and concrete experience of interactions with butas enables the people to form and sustain the transactional network composed of a more extensive circulation of substance-codes, including raising agricultural products; caring for the land, nature, and deities; receiving the wild śakti; and reproducing their lives and social relations in the village community. 


\section{Notes}

1 For recent studies focusing on animism, in addition to the works of Viveiros de Castro and Willerslev examined in this chapter, see, for instance, Descola (1996), Bird-David (1999), and Pedersen (2001).

2 As mentioned in Chapter 1, recent studies on magical-religious phenomena, including spirit possession, tend to analyse them not as a mere critique of modernity, but as components of it (e.g. Behrend \& Luig 1999; Comaroff \& Comaroff 2002). One can still find in this new trend the vestiges of the conventional framework of recasting these phenomena as political discourses about modernity. For a critical view of this trend, see Kapferer (2003) and Ranger (2007).

3 This analytical position corresponds to those of the several previous studies examined in Chapter 6, which tend to analyse the individual-dividual dichotomy as if it corresponds with Western and non-Western personhood (e.g. Busby 1997; Rasmussen 2008; Mosko 2010). At the same time, as Johnson critically points out, nearly all ethnographers 'must now at least address the prospect of their possession, respond to it, apologize for its lack, somehow account for it, as they construct their authorial position in relation to the work of spirits' $(2011$, p. 417 , italics original).

4 See, for instance, Mead (1927), Merleau-Ponty (2012 [1945]), Piaget (1954), Schütz (1970), Husserl (1973), Blankenburg (1991), and Sakabe (1999).

5 See, for example, Pedersen (2001), Kohn (2007), Pedersen, Empson and Humphrey (2007), and Swancutt (2007).

6 Holbraad and Willerslev (2007) also present an alternative to Viveiros de Castro's model by illustrating the Inner Asian 'transcendentalist' model characterised by the asymmetrical, temporal, and generative transformation of one's perspective.

7 On the instability and vulnerability of the self and the body, see also Taylor (1996) and Vilaça (2005).

8 In her investigation of Mongolian games, Swancutt (2007, p. 240) points out that shifts in perspective bring about long-term changes in personhood. Additionally, Santo (2012) analyses spirit mediumship in Cuba as the mutual constitution of self and spirit, which implies the development of a particular kind of self.

9 Büta worship at the village level is characterised by relatively systematic training and ritual processes similar to those of other theatrical performances in India (e.g. Frasca 1990; de Bruin 2006).

10 This ability of the būta medium can be understood through Lienhardt's (1961, pp. 151) notion of 'passiones' (see also Kramer 1993, p. 58; Lambek 1993, p. 312; Ishii 2012).

11 In the būta ritual, the deity incarnated in the medium calls out the names of the 16 guttus according to their rank.

12 Ākarșaṇe and āvêśa mean spirits' 'attraction' and 'possession', respectively (Upadhyaya 1988-1997, pp. 219, 277). Possession by būtas is variously described such as jogga (ecstasy), darșana (trembling owing to spirit possession), and büta pattundu ('the büta caught ...') (see Claus 1984; Smith 2006, p. 138).

13 In the nēma, the mukkāldi and the Pambada dancer-medium are usually possessed by turns.

14 Regarding the transformation of perspective, Blankenburg (1991) points out the importance of one's ability to play with the various perspectives that one happens to be given. See also Sakabe (1999) and Ishii (2013). 


\section{Part Two}

Social transformations

and the emergence

of a new umwelt 

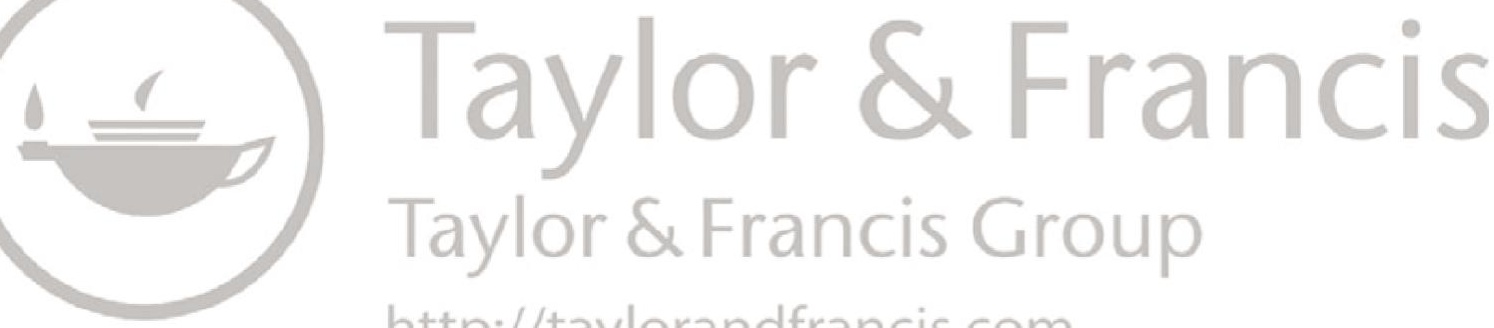

http://taylorandfrancis.com 


\section{Büta's agency in conflicts over the village shrine}

In Part One, we examined various aspects of būta worship in Perar, such as the characteristics of büta worship related to land, nature, and the social composition of the village; the ritual practices based on the kattu; and the experiences of each person involved in the ritual. It was necessary to examine these issues first in order to understand the büta worship that forms a part of the umwelt for the villagers, as linked inseparably with land and nature, houses and their ranks, people's lives and roles, and the myths and local history of the area.

Needless to say, however, būta worship in Perar has been involved in much wider social and political contexts and has undergone numerous historical transformations. In Part Two, I will investigate issues such as the advent of the modern judiciary and administration, as well as the expansion of massive development projects, which have caused drastic changes in village communities. Focusing on the relationship between people and deities, I will examine various practices of the people who live in the midst of entanglements and conflicts between customary orders, systems, and śakti on one hand, and novel orders, systems, and power on the other.

In this chapter, I will examine the transformation of büta worship, focusing on the development of the modern judiciary and administration as well as their effects on villagers' lives. Through this investigation, I attempt to show the significance of the deities' agency, not only in rituals but also in the wider social and political context.

As we have seen, būta worship in Perar is based on a hierarchical system consisting of the 16 guttus and the ritual servants, and every role and detail of the rituals is strictly determined by the kattụ. At the same time, whether rights and honours in reward for ritual services can be granted to a particular person or family depends on the deities' approval. Therefore, while būta worship is thoroughly structured by customary law and systems, the entirety of the custom and people's rights and ranks is based on ritual practices, the core of which is formed by direct interaction between people and deities.

In addition to customary law and systems, modern law and administration are important factors concerning rights and rulings in būta worship. Villagers' rights and duties in būta worship have been determined by 
customary law, systems, and ritual practices, but at the same time, they have been formed and reformed by modern law and administration since colonial times.

As we will see in this chapter, the villagers participating in the būta rituals in Perar have responded to the modern judiciary and administration, which have promoted the regulation of religious institutions. In their endeavours to deal with the new conditions, some people have attempted to use modern law and systems to increase their own rights and interests regarding the management of the village büta shrine. The heads of the higher-ranked guttu houses, who were traditionally in charge of būta worship in the village but have confronted these new demands, have also felt pressured into appealing for their shrine rights in conformity with modern law and systems.

At the same time, people frequently turn back to the realm of traditional ritual practices. These are governed by the deities' sovereign agency, which emerges through possession and oracles. Through the mutual communication of people and deities in the ritual, the relations among people regulated by modern law are again converted into those arranged by the customary law authorised by būtas' divine agency.

In this chapter, I will investigate the practices of people who need the power of the bütas at the core of rituals, but also must engage with modern law and systems. Through this investigation, I will show how modern law and customary law encounter each other regarding religious practice and become entangled despite having different origins and histories and representing different logics and values. I will also describe the endeavours of the people, who are in between the diverse orders of the courts and the deities, to reorganise their social relations regarding būta worship. First, I will outline the previous studies on the institutional transformations of Hindu temples in South India to understand the situation in the būta shrine. Next, referring to Gell (1998), I will highlight the importance and actuality of the deities' agency in the context of the modernisation of, and institutional changes in, religious institutions, which is rarely discussed in the previous studies. Lastly, I will closely examine two cases of disputes over the village būta shrine in Perar, focusing on the relations and mutual effects between legal disputes and ritual practices. The first case is a lawsuit in the early 1930s dealing with the trusteeship of the village butta shrine. The second case is an ongoing dispute since the beginning of the 2000s caused by a movement in Perar that has aimed to create a legal subject of shrine management by organising a committee.

\section{Modern administration of religious institutions in South India}

Anthropologists studying Hindu temples in South India have focused on the institutional changes in the temples caused by bureaucratic centralisation under colonial rule. From the 1970s to the 1980s, a number of important 
studies on the rise of colonial power, the decline of traditional kingship, and the transformation of Hindu temples were published. ${ }^{1}$ These studies on the relations of Hindu temples and kingships, the colonial government, and the modern nation state provide an important reference point for considering the transformation of the büta shrine as a religious institution in South Kanara. At the same time, by examining the relation between customary law and modern law in concrete practices in the butta rituals, it becomes possible to reconsider the perspective of previous studies that tend to disregard the agency of deities, an agency that influences not only ritual proceedings but also judicial procedures. Focusing on Appadurai (1981), I will next provide an overview of the studies on Hindu temples in South India.

Appadurai described the transformation of the Śrī Pārtasārati Svāmi temple in Madras city, Tamil Nadu, in reference to social and political changes from the fourteenth to the twentieth century. The foci of his study were the relationships between kings, sects, and temples in the pre-colonial period, and institutional changes and conflicts caused by the advent of colonial power after 1700. First, Appadurai pointed out the importance of the deity as the paradigmatic sovereign in the Hindu temple in pre-colonial South India. As discussed in Chapter 6, he focused on the role of the deity as a very special person, who should be placed in the centre of the transactional network. According to Appadurai, it was the process of redistribution in the temple that enabled the deity to be the paradigmatic sovereign; the deity received offerings from devotees, and in return granted them honours along with various rights and authority. Through mutual exchange with the deity, people were involved in the transactional network centred on the deity (Appadurai 1981, pp. 20-37).

Based on the exchange of offerings and honours, the deity thus reigned over the people. At the same time, because it was made of stone, the deity could not really arbitrate or adjudicate conflicts among devotees concerning shares and rights. Therefore, the king, who was the greatest endower to the temple and also shared in the paradigmatic royalty, fulfilled the function of arbitrating conflicts and protecting the temple. The role of the king in regard to the temple, however, was not legislative but administrative (Appadurai 1981, pp. 50-51, 214; see also Appadurai \& Breckenridge 1976, pp. 206-207). This delicate system was greatly altered with the introduction of British rule. In accordance with the development of a centralised bureaucracy, the British gradually expanded their day-to-day involvement with temples but grew reluctant to resolve temple disputes. Disputes concerning the temple were regarded as the object of judicial trials, and the institutional separation of the executive and the judiciary created ambiguities in the arbitration of temple disputes. The temple and the Anglo-Indian judiciary grew entangled, and trials based on modern law provoked new conflicts over shares and rights in the temple (Appadurai 1981, pp. 109-110, 215).

The outline of the historical transformation of Hindu temples described by Appadurai, i.e. the close relationship between temples and kings in the 
pre-colonial period, and the decline of kingship and institutional changes in temples in accordance with the advent of the modern bureaucracy and judiciary, is broadly shared in most studies on Hindu temples in South India. For instance, Fuller (1984, pp. 104-109), who examined the transformation of the role and status of Brahman priests in a Hindu temple in Tamil Nadu, called the indirect exchange relationship between kings, priests, and deities a 'triangular scheme' and pointed out the importance of this relationship for sustaining the traditional kingship and temple. He argued that this cycle of exchange was then destroyed under British rule because the secular state could not undertake the role of the traditional king in relation to the deity. ${ }^{2}$ Likewise, Dirks (1987), who investigated the historical vicissitudes of a kingdom called Pudukkottai located in Tamil Nadu, described that the penetration of the bureaucratic regime from the nineteenth century onwards hollowed out the traditional kingship and provoked new conflicts over honours given in temples. According to Dirks, people came to use new forms of discourse and definitions based on administrative ideas and modern law to mediate conflicts over temple honours, whereas these used to be arbitrated by kings. This led to the reinforcement of the bureaucratic regime as well as the commoditisation of honours and the commercialisation of worship (1987, pp. 358-383).

As seen above, previous studies presume a certain historical transformation of South Indian temples, from the rule of kings and deities to control by the modern state and law. However, referring to Gell (1998), I will examine the relationship between people and deities by focusing on their mutual exchange and point out the actuality and effect of the deities' agency, which has been disregarded by most previous studies.

\section{Transactional networks and the deity as a 'sovereign person'}

Previous studies on Hindu temples in South India have described how in the nineteenth century, in accordance with the advent of the modern judiciary and administration, traditional kingship declined and temples came under the control of the modern state and law. This transformation process of Hindu temples is broadly similar to the transformation that the büta shrine has undertaken as a religious institution in South India. As we will see later, the rise of modern administration caused new conflicts over shrine management, and consequently the būta shrine has inevitably undergone institutional transformation.

When we closely investigate the practices of būta worship, however, it is clear that we cannot presume a unilateral transition from the rule of kings and deities to control by the modern state and law. As we will see in this chapter, the people participating in büta worship are certainly under the control of the modern state and law, and moreover, they practically support this control by responding to, and making use of, the modern judiciary and administration. At the same time, by communicating with deities and 
consulting oracles, people strive to comprehend and act in conformity with the deities' agency, which directs the state of affairs in the realm of jōga. Under these circumstances, people's legal rights and duties-determined by modern law and administration - and their customary rights and duties (adikāra) - based on their actual interactions with deities-are variably in conflict, overlapping, and transposed. Since the colonial era, būta worship in South Kanara has been conducted in situations in which the power of the modern judicial and administrative systems and deities' agency have been entangled, and thus the rules and systems regarding ritual practices and shrine management have been duplicated. Regarding these issues, I will reconsider the transactional network between deities and devotees in Hindu temples before considering concrete cases.

As seen in the previous section, Appadurai illustrated how in a pre-colonial South Indian Hindu temple, the deity reigned over the people through a mutual exchange relationship with devotees. At the same time, because the deity could not arbitrate disputes, the authority of the deity was complemented by the power of the king, who arbitrated conflicts and protected the temple. In accordance with the rise of the colonial power and the hollowing out of traditional kingship, disputes over honours and rights in the temple came to be judged by modern law, and the temple fell under the control of the modern state and law.

When discussing the Hindu temple in the pre-colonial period, Appadurai emphasised the importance of the deity as a special person and the importance of the transactional network between the deity and devotees. ${ }^{3}$ Strangely, however, in his description of the institutional transformation of the temple in the colonial era, the deity as a special person disappeared. There may be two reasons for this absence: first, Appadurai described the transformation of, and disputes over, temples in the colonial era primarily based on court records. Since he depended on records written in the terminology and logic of modern law, perhaps he overlooked the concrete relationship between the deity and devotees. Second, while Appadurai focused on the social personhood of the deity as a prerequisite for establishing the ritual transaction that supported the centrality of the temple, he did not consider the possibility that the deity could actually manifest its agency towards people in cases of dispute. Based on his disregard of the deity's agency, Appadurai could conclude that the temple was fundamentally transformed by the decline of the king and fell under the control of the modern state and law. When we reconsider, however, how the deity as a special person is not only a prerequisite for the ritual exchange in the temple but also something which emerges again and again through the interactions between the deity and devotees, we become aware of the possibility that the deity actually exercises agency in the chain of gift-exchange.

Regarding this issue, Gell (1998), who investigated the agency of nonhumans such as artefacts and deities in social relations, offers an important perspective. Though he studied the agency of idols and deities through 
many cases, here I will introduce only two. The first example is the religious practice in ancient Tahiti. Based on Babadzan (1993), Gell examined the exchange relationship between the priests, hunters, and the ' $h a u$ of the forest', or the principle of the productivity of the forest. The exchange of these three participants forms a cycle: the priests make offerings to the hau of the forest, the hau of the forest responds by providing the hunters with birds to capture, and a portion of these birds must be returned to the priests. According to Gell, in this exchange process, the forest is considered to be passive in relation to the priests, who are the prime movers. It does not mean, however, that the forest has no intrinsic agency at all. The agency of the forest, that is its potential productivity, has simply been co-opted by the agency of the priests (Gell 1998, pp. 106-109).

The exchange relationship between the priests, hunters, and the hau of the forest is similar to the triangular scheme of the priests, kings, and deities in Hindu temples, as described by Appadurai and Fuller. ${ }^{4}$ Likewise, a similar structure can be observed in the exchange relationship in the büta ritual, where the priests, the heads of the 16 guttus, and butas act as the main participants. In Gell's argument, it is important that the agency of the hau of the forest is manifested towards humans through the cyclic exchange and distribution of the fertility of the forest. If we extend this idea to the gift-exchange in a Hindu temple, the deity who is the centre of the transaction of offerings and honours is considered not just to be a special person as the prerequisite for the exchange relation, but rather to become the social actor who manifests agency through the ritual transaction.

Next, based on Eck (1998 [1981]), Gell focused on the exchange relationship between devotees and images of Hindu deities through eye contact. According to Gell, by looking into the eyes of the deity, a devotee obtains darshan (Skt. darśana), a particular type of blessing from the deity conveyed through the eyes. ${ }^{5}$ Darshan is a gift, or a mode of divine agency, and the worshipper is the patient who receives it. At the same time, s/he is also an agent who initiates the transitive action of 'taking' it (darshan lena) from the deity. Through the mutual relationship of looking and being seen, the deity and the worshipper each come to be both agent and patient in relation to the other (1998, pp. 116-120). ${ }^{6}$

Gell's argument shows that, through the mutual exchange between deity and devotee, both become social actors in a transactional network, and at the same time, the agency of each actor is evoked. According to Gell, even if it is a statue or a painting, the deity is able to manifest its agency in the transactional network. From this viewpoint, the transactional network in a Hindu temple is considered to be not simply formed on the assumption that the deity is the supreme sovereign; rather, it is the dynamism of the transactional network through which the agency of the deity comes to be manifested and actualised. Therefore, it is considered that as long as the ritual is performed, the deity's agency continues to manifest itself and affect the process of exchange and redistribution, even though the power of the king is no 
longer and instead government officials are involved. ${ }^{7}$ Gell mainly focuses on the agency of idols and artefacts, but in the case of spirit possession in which the deity manifests itself in the body of a medium, the deity's agency can be perceived far more obviously and distinctively by the devotees.

Based on the theoretical viewpoints examined above, I will next investigate the people's struggles in the midst of entanglements of, and conflicts between, customary law and modern law, and those of and between the deities' agency and the power of the courts.

\section{Disputes over the trusteeship of the village būta shrine in the 1930s}

In this section, I will examine a lawsuit in the early 1930s regarding the trusteeship of the village büta shrine in Perar, which was disputed between the higher-ranked guttu families and the then asrāṇna. Before considering this case, I will provide a brief overview of the legislation on religious institutions in South India before the 1930s.

The Madras Endowments and Escheats Regulation, 1817 (Regulation VII of 1817) was the first legislation on religious institutions in Madras and was superseded by the Religious Endowments Act of 1863 (Act XX of 1863). In 1926, the Hindu Religious Endowments Board (henceforth the HRE Board) was formed and the Madras Hindu Religious Endowments Act (Madras Act II of 1927, henceforth the HRE Act) was passed by the Madras Legislative Council. Through the foundation of the HRE Board and the HRE Act, the state enhanced its administrative power over local temples and gradually undermined the autonomy and traditional authority of local temples (Presler 1987, pp. 15-35). Under these circumstances, the trusteeship of local religious institutions became a common subject of competition and dispute (Appadurai 1981, pp. 52-53; Dirks 1987).

As we have seen, the village büta shrine in Perar consists of the māḍa for Arasu and the cāvaḍi for Balavāṇḍi, and the special sanctuary or guṇụa for Bramma. The daily worship and rituals for Bramma are only conducted by an asrāṇna, a Brahman priest who is hired by the Muṇạabețu guttu for this purpose.

However, in 1928, L. Udupa, who was then the asrāṇna of the village būta shrine in Perar, filed a suit in the district court against the then head of the Mundabetțu guttu 'for delivery of the properties appertaining to the Padu Perar institution' (Original Suit [O. S.] No. 26 of 1932: 6). ${ }^{8}$ This case was contested before the subordinate judge of South Kanara in 1932, with L. Udupa as the plaintiff and the six main members of both the Mundabetțu and Brānabetțu guttus as the defendants. There were three main points of contention in the suit: first, which religious institution in Perar could be identified as the one over which the asrāṇna insisted on his trusteeship; second, who had received the allowance (tastiku) granted by the government to the religious institution in question; and third, whether the institution in question 
was a 'hereditary temple' that could be 'excepted' from the provisions of the HRE Act. ${ }^{9}$ According to the court record, the Padu Perar institution in question was registered in Mangalore taluk in 1875 as 'Perar Shastavu Brahma Bhoota' (O. S. No. 26 of 1932: 9). An asrānnna named A. Shibaraya was the then trustee (moktesare) of the institution and he had an allowance of nine rupees from the government. Since this precedent, the person who became the asrānnạa received the institution's allowance. In addition, L. Udupa had been appointed by the Mangalore Circle Temple Committee (later replaced by the South Kanara District Temple Committee), which had been constituted under the HRE Act, as a trustee of an institution in Padu Perar described as 'Shastavu Brahma Balavandi'. Based on these facts, L. Udupa insisted on his trusteeship of the village būta shrine, which he identified as 'Shastavu Brahma Balavandi Pilichamundi Daivastanam' of Padu Perar.

On the other hand, the guttu members insisted that the Padu Perar institution was known not as 'Shastavu Brahma Balavandi Pilichamundi Daivastanam', but as 'Kinni Majalu Ishta Devata Balavandi Pilichamundi Daivastanam', whose management was traditionally vested in the hereditary rights of the Mundabețu and Brānabețu guttus. They also insisted that the institution was a 'hereditary temple' exempt from the provisions of the HRE Act; therefore, neither the Mangalore Circle Temple Committee nor the South Kanara District Temple Committee had jurisdiction over it.

After a number of hearings and detailed investigations into exhibits from both the plaintiff and defendants, the court finally settled the suit in September 1933. Among the total of 57 exhibits, the one the judge regarded as the most decisive was a report submitted to the Temple Committee in January 1930 by A. S. Pai and P. V. Rao, both advocates of the court and members of the Temple Committee. According to the report, they inspected the Padu Perar institution in question in the presence of the plaintiff (L. Udupa) and first defendant (J. Naik) and held an enquiry. B. G. Avargal, the then Subordinate Judge of South Kanara, stated the following about this report in the court record:

They observed in their report that the form and appearance of the building in which the idol of Brahma was kept led them to conclude that the building was a temple and not a Daivastanam [būta shrine] but that the 'mada' of Ishta Devate [another name of Arasu] and the 'chavadi' of Balavandi within the same enclosure had the appearance of Daivastanams ... They have further observed as a result of their inspection and enquiry that the institution for which the Plaintiff was appointed trustee by the Mangalore Circle Temple Committee and for which tasdik was paid by Government is the one in Padu Perar, that the principal deity therein is Brahma and that the 3 daivas, viz., Ishta Devata, Balavandi and Pilichamundi, are subsidiary deities.

(O. S. No. 26 of 1932: 7-8 [emphasis mine, to illustrate the hierarchy of the deities presumed by the judges]) 
Based on the observations of two influential advocates, the judge concluded that the institution for which L. Udupa was appointed as a trustee was identified as the Padu Perar institution (that is, the village büta shrine), in which Bramma was the presiding deity and the other butas were attendant deities. The judge also pointed out that the Padu Perar institution was not an 'excepted temple', since it had at least one office of trustee that was not hereditary (O. S. No. 26 of 1932: 19-21). The judge thus approved the Temple Committee's right to exercise jurisdiction over the institution and therefore decided that its appointment of L. Udupa as a trustee was valid.

At the same time, based on documents of land purchase in the name of the village buta shrine, the judge authorised that the representatives of the two guttu houses had undertaken the management of the shrine property. As already seen, the land owned by the village buta shrine was managed by the heads of the first and second guttu families, and rewards for ritual servants had been paid in products of the land. The documents about land purchase with the joint signatures of the then heads of the Mundabețtu and Brānabetțu guttus were recognised as proof of their hereditary trusteeship of the property of the village būta shrine. Therefore, while the judge approved the official trusteeship of the asrānnna appointed by the Temple Committee, he also approved the hereditary trusteeship of the first and second guttu houses. In conclusion, the judge gave the decision that the plaintiff and the defendants should be co-trustees of the property of the Padu Perar institution. ${ }^{10}$

In this judgement, Bramma was identified as a quasi-Hindu god enshrined in a 'temple' and regarded as superior to the other bütas. In the same manner, the judgement guaranteed the status of the asrānna as the priest for the main deity and also the trustee of the institution. This judgement was apparently influenced by the preconceptions of the judge and two advocates, who presumed the supremacy of Sanskritic deities.

As we have seen, Bramma has ambivalent characteristics both in the pāḍdana and in worship at the village būta shrine, for he is treated as a local as well as a Sanskritic deity. In conjunction with legal discourse, the Sanskritic aspect of Bramma became evidence of his supremacy and the existence of Brahmanical caste hierarchy in the village būta shrine. As a result, at least at the level of legal discourse, the village büta shrine in Perar became recognised as an institution where a quasi-Hindu god is the supreme deity and a Brahman priest occupies a crucial status.

The modern judicature, which presumed the supremacy of Hindu gods and focused only on 'objective facts' such as the structure of the village butta shrine and the appointment of a trustee by the Temple Committee, could comprehend neither the mutual interactions between the buttas and devotees nor the centrality of the bütas embodying the circulation of wild śakti. In this judgement, the royal būtas were marginalised as subsidiary deities to Bramma. At the same time, the roles of the guttu houses, which had been pivotal in both ritual practice and shrine management, were disregarded, except regarding their management of shrine property. 
As seen above, through the formulation and penetration of modern law and administration from the end of the nineteenth century to the beginning of the twentieth century, similar to most religious institutions in South India, the būta shrine in Perar was also involved in rulings by the modern state and law. The court record examined in this section, however, suggests that while successive asrānnas strived to expand their rights in the village būta shrine by using new laws and systems, the heads of the higher-ranked guttus had rather negative attitudes towards modern law and systems.

For instance, in the trial in 1932, the heads of the first and second guttus insisted that the village būta shrine was a private, hereditary temple exempt from the provisions of the HRE Act. The heads of the guttus probably resented the bureaucratic administration of the shrine, so they intended to keep their distance from it. At the same time, their negative attitude to modern law and administration also seemed to be based on their principle of putting the highest priority on the kattụ and bütas' oracles, which formed the basis of social relations in the village and linked villagers to the wild śakti. For the heads of the guttus, who had assumed charge of the village būta shrine based on ritual practice and observance of the kațtụ, the adikāra granted by the deities was the matter of highest priority. Therefore, at first, they did not give much importance to rights and allowances granted by the state. Only when their hereditary trusteeship was endangered by the asrānna who tried to expand his rights and interests through the authority of modern law, did the heads of the guttus begin to appeal for their rights in terms of modern law.

As we will soon see, the heads of the guttus found themselves in a similar predicament again about 70 years later regarding shrine management and strived to solve the difficulty in between the power of modern law and the agency of deities.

\section{The foundation of a management committee and the crisis of traditional rights}

I will next investigate people's endeavours in between customary law and modern law, focusing on the ongoing conflict over the management of the village būta shrine. First, I will outline the rise of a new faction claiming rights to shrine management as well as the response of the higher-ranked guttu houses, focusing on their relation to modern law.

A series of incidents began in 2000 with the advent of a man who presented himself as a relative of the third guttu family in Mudu Perar. His name was N. Shetty, a wealthy restaurateur living in Mangaluru city. He explained to villagers that he was told by an astrologer that his ancestors had originated from the third guttu family and that he therefore came to Perar for the purpose of contributing to his ancestors' land. He soon started various activities using his abundant funds. First, he reconstructed the shrines of Nāga and būta on the estate of the third guttu house. He also asked two 
folklorists to collect the oral epics in Perar and published a pamphlet. Moreover, in 2001, he established a committee called Sēvā Samiti (service committee) for organising būta rituals in Perar. In this process, N. Shetty invited about 80 villagers to the committee and organised them. The committee began to gradually take charge of the preparation of the nēma and also of the administrative work regarding the village büta shrine, tasks conventionally undertaken by the members of the first and second guttu families.

At first, the members of the committee and the heads of the first and second guttus maintained a good relationship. When establishing the committee, N. Shetty persuaded these guttu heads by insisting that the aim of the committee was only the development of the village būta shrine. Gangādara Rai, who was the head of the Mundabettu guttu and served as the gadipatinārụ at the village būta shrine, agreed to the committee's establishment, and N. Shetty asked him to be the committee's honorary president. Soon afterwards, however, the situation took a turn for the worse for the guttu families. In early 2002, the asrāṇna who had taken charge of donations to the shrine in cooperation with the gaḍipatinārụ was discharged after a quarrel with the committee members, and the committee came to hold the key to the safe and started to manage the finances of the shrine directly. The discharged asrāṇna was called B. Udupa, a descendant of the L. Udupa who had filed the 1928 suit described in the previous section. This Brahman family had long held the office of asrāṇna in Perar. After B. Udupa left the village būta shrine, N. Shetty brought a young Brahman priest from another village and placed him in the position of asrāṇna.

Triggered by this incident, discord between the committee and the first and second guttus soon came to the fore. The head of the Mundabettu guttu appealed to the Deputy Commissioner of the Dakshina Kannada district that their family held hereditary trusteeship of the village büta shrine and petitioned for their right to shrine management. The Deputy Commissioner, however, turned down this petition and instead granted the right to N. Shetty, who was the representative of the service committee in Perar. Dissatisfied with this decision, Gangādara Rai and other core members of the Mundabețtu guttu appealed to the Commissioner for Hindu Religious Institutions and Charitable Endowments in Bangalore, who was superior to the Deputy Commissioner. ${ }^{11}$ Meanwhile, N. Shetty formed a new management committee, which was prescribed in the Hindu Religious Institutions and Charitable Endowments Act, 1997 (Karnataka Act No. 33 of 2001), and again appealed to the Deputy Commissioner for the committee's right to manage the shrine in Perar. This case was carried into the High Court of Karnataka, and as of 2015, it was still the subject of litigation.

In this series of disputes, it is interesting how the Mundabețtu guttu family represented by Gangādara Rai and the committee led by N. Shetty have constructed their respective claims. Referring to the court records kept in the Deputy Commissioner's Office (Records of Disputes on Law CR No. 7/2002-2003), ${ }^{12}$ we can grasp the primary logic of each side. For instance, 
in the statement submitted in 2003 by the advocate of Gangādara Rai to the Commissioner for Hindu Religious Institutions and Charitable Endowments, the advocate denounced the Deputy Commissioner for appointing N. Shetty as the fit person to manage the shrine, and appealed the decision as follows:

The 6th respondent [N. Shetty] intends to usurp the Trusteeship of the Daivasthana [the village büta shrine] and interfere with the day to day management of Daivasthana. In fact the overall management of Daivasthana is being looked after by the appellant [Gangādara Rai] as one of the joint hereditary trustees ... The 1st respondent [the Deputy Commissioner] by order dated 27-4-2002 appointed the 6th respondent as the fit person ... The 1st respondent has no jurisdiction to appoint the fit person or frame a scheme when there are hereditary trustees ... The order under challenge is arbitrary and illegal ... Any activities undertaken by the Samithi [committee] were under the guidance of the appellant and Sadashiva Shetty [the head of the second guttu family] as heads of the Committee. The appellant had hardly dreamt then that the very Samithi created by him would prove self-destructive and threaten the very position of the appellant as trustees. The appellant had hardly realized then that he was being tricked and deceived.

(Records of Disputes on Law CR No. 7/2002-2003: 176-178)

Meanwhile, in the statement submitted in 2002 to the Deputy Commissioner, the advocate of N. Shetty stated that the village büta shrine in Perar was a public religious institution in which Bramma was the presiding deity and accused the conventional managers of the shrine of negligence:

There has been no declaration or any order to the knowledge of the petitioners [N. Shetty and others], as contemplated under the provisions of Madras HR \& CE [Hindu Religious and Charitable Endowments] Act ${ }^{13}$ regarding the alleged right of hereditary trusteeship of the respondent [Gangādara Rai] ... The respondent did not account for any of the income. He had not paid the contribution payable by the Daivasthana, and the accounts were not audited for several years. The respondent had not shown any interest in the betterment, development, improvement or maintenance of the institution.

(Records of Disputes on Law CR No. 7/2002-2003: 183)

In addition, the advocate enumerated the achievements of the committee, such as the improvement of the facilities of the shrine and the properness of the management, and argued for the necessity of framing a scheme for the better management of the village shrine:

Such rules or regulations are very much necessary to define the powers, duties, rights and responsibilities of the persons in management. 
Accountability can be imported to the management only by such a Scheme. It is a common well accepted principle that when power of administration and management are given, the accountability and responsibility has to be incorporated with the powers so that there will be scope for exercising control.

(Records of Disputes on Law CR No. 7/2002-2003: 186)

As seen in these statements, throughout these disputes, the members of the Mundabețtu guttu consistently insisted on the authenticity of their hereditary trusteeship and criticised the committee for taking over their rights in the village büta shrine. Meanwhile, the members of the committee criticised the slipshod management of the guttu members and insisted that the committee could improve the shrine by managing its property more effectively. There is an obvious contrast in the two sides' statements regarding what is of most importance for shrine management: while the Mundabettu guttu insisted on the priority of hereditary and traditional rights and duties, the committee based their claims on the rationalisation of management and the establishment of discipline. It is also notable that both sides hired advocates and constructed their opinions according to the logic and terminology of modern law.

As already seen, while the traditional rights and duties (adikāra) of the guttu houses are determined by the kattụ, they are actualised only through interaction with, and approval by, the deities in rituals. Here, the adikāra are based on an agreement between the deities and the heads of the guttu houses, an agreement believed to extend back to ancient times; and for these heads, to conduct a ritual according to the kattu means to accomplish their duty and to exercise their rights in butta worship. Needless to say, in the realm of customary law and ritual practice, the supreme authority which approves or disapproves of people's rights regarding büta worship has been vested in the deities.

Meanwhile, in the lawsuit regarding shrine management rights, the supreme authority is vested in legal procedures and court orders, and the authority and effectiveness of the deities' orders are disregarded from the start. The points of contention in the court are neither the ancient agreement with the deities based on pāddana nor the appointment of the gadipatinārụ by the deity, but the management and administration of the shrine in relation to government offices and the matter of who is appropriate for trusteeship in terms of modern law.

The adikāra of the higher-ranked guttu houses, which can be called 'hereditary trusteeship' in the terminology of modern law, is based on the detailed kațtụ, pāḍdana, and mutual interaction with deities, and it is very difficult to legitimate their factual grounding. The actors who compete with the Mundabețtu guttu for trusteeship or management rights of the village būta shrine, such as the asrāṇna and N. Shetty, neither appear in the pāḍdana nor have been approved by the deities. Simply by being registered as 
the trustee with the government and approved by its jurisdiction, however, they can gain an advantage over the guttu families. Therefore, the members of the higher-ranked guttus involved in the dispute recognised that they should also claim their rights in the logic recognised by the judiciary.

As seen in Chapter 5, in a ritual in the village butta shrine, the heads of the 16 guttus pleaded with the deities for their blessing and authorisation, and at the same time, they performatively consented to the supremacy of the deities by obeying their orders. For the heads of the guttus, this is the essential procedure for maintaining their relationship with the realm of the wild through interactions with the deities manifested in spirit possession. In the process of the lawsuits and court trials, however, the guttu families seem to be longing also for the approval of the judiciary and to be obeying the authority of modern law. Rights and duties regarding the būta worship, which the members of the guttus and ritual servants must hold, seem to have changed in meaning from the mythical adikāra to trusteeship confirmed by modern law. If so, in the series of disputes, does the practice of people competing for judicial approval indicate a transition from customary law to modern law, from divine oracle to court order, and from adikāra to legal rights? Next, I will consider these issues by focusing on the nēma in 2009.

\section{A conflict in the nēma and the judgement of the deity}

As of March 2009, in the series of disputes between the Mundabețtu guttu and the management committee, the committee held the advantage, and the preparation of the nēma was carried out by the members of the committee. As we will see in this section, however, the nēma, which seemed to be proceeding smoothly under the command of the committee, fell into confusion due to the fierce anger of Balavāṇdi incarnated in the mukkāldi. In the judgement ritual (vākụ piripuni) in the final part of the nēma, the oracles of the bütas restored some of the customary rights of the gadipatinārụ which had been taken over by the committee. I will summarise this process below.

A short while after 11 o'clock on the night before the nēma, the ritual which should have started an hour before had still not yet started, due to the absence of the mukkāldi. Devotees were seated on the cloister of the precinct of the village būta shrine waiting for the ritual to begin. It was almost midnight when the mukkāldi, possessed by Balavāṇ̣i (hereafter, Mukkāldi-Balavāṇụi) and accompanied by the heads of the guttu houses, appeared in the precinct. Mukkāldi-Balavāṇni had covered his head with a white turban and was trembling all over and occasionally groaning. He rushed at one of the guttu heads and knocked him down, so then others frantically tried to restrain the deity. Mukkāldi-Balavāṇụi sat on a seat on the cloister and a crowd surrounded him. They watched his movements with bated breath. The tense silence persisted for some time. Suddenly, Mukkāldi-Balavāṇ̣̣i jumped up from his seat and rushed forwards, scattering the crowd around him. He dashed towards the treasure house, and the heads of the guttus hurried to 
follow him. The nēma, which was held from 10 to 13 March 2009, thus had a very turbulent start.

Prior to this extraordinary expression of anger of Mukkāldi-Balavāṇdi, there were several incidents in the conflict between the Mundabețu guttu and the committee. It began with an incident regarding invitations to the nēma. A few weeks before the nēma, several members of the first and second guttu families made invitations and delivered them to the main houses in the village. The members of the committee responded by publishing an article in a local newspaper accusing the guttu families of 'illegally' sending invitations as if they were the organisers of the nēma. In the midst of the tension between the two factions enflamed by this affair, the second incident happened. Traditionally on the day before the nema, the members of the Mundabettu guttu with the help of villagers had treated the visitors to the nēma to lunch in a public hall next to the village büta shrine. This year, however, the members of the committee refused to give the key to the public hall to the villagers on the side of the Mundabețtu guttu. The quarrel over the key between the villagers and the committee members quickly escalated, and finally a police officer from the neighbouring town was called on to settle the quarrel. Hearing of this, Mukkāldi-Balavāṇdi flared up and declared that he would not enter the shrine profaned by the disturbance. On the next day, N. Shetty, the leader of the committee, apologised to the deity for blaspheming the shrine with the matter involving the police, but the anger of Mukkāldi-Balavāṇụi was not assuaged.

The nēma proceeded in this tense atmosphere, and finally it came time for the ritual of the judgement (vākụ piripuni), which was the most important ritual of the last day. This ritual is usually held at Bantakamba, which is about 80 metres far from the village shrine. This time, however, the ritual of the judgement concerning the conflict between the Mundabettu guttu and the committee was held in front of the Bramma guṇa, in the precinct of the shrine. Mukkāldi-Balavāṇụi, Pilicāmuṇụi incarnated in Jayānanda Pambada, and the heads of the 16 guttus stood in front of the gunda, and a crowd surrounded them. N. Shetty also stood alongside of the heads of the guttus. The exchange of anger and entreaty between the deities and the heads of the guttus continued for several hours. Mukkāldi-Balavāṇ̣i harshly accused the guttu heads of violating the katțu and causing disaster, and the heads of the guttus strived to placate the deities. After a long time, the ritual finally ended with an oracle by Mukkāldi-Balavāṇdi ordering observance of the katț̣ and reconciliation between the Mundabețtu guttu and the committee:

You should be together. Otherwise, all of you will suffer. We need the pergade [the head of the first guttu], madyaste [the head of the second guttu], the sixteen guttus and the villagers.

The heads of the guttus and N. Shetty together held jasmine flowers on a banana leaf and swore to obey the oracle. The ritual of the judgement ended 
with the oracle and the vow, and at the end of the nēma, Mukkāldi-Balavāṇdi and Jayānanda-Pilicāmuṇ̦i blessed both the heads of the guttus and N. Shetty by touching their hands with swords. On the next day, the gadipatinaru and $\mathrm{N}$. Shetty together opened the safe of the shrine, and according to the custom before the establishment of the committee, the rewards for the ritual servants were paid from the hands of the gaḍipatinārụ.

The process of the nèma examined above provides us with a new perspective from which to understand the relation between būta worship, customary law, and modern law. As we saw, in the dispute between the higher-ranked guttus and the committee over the management of the shrine, both factions appealed to the modern judiciary and administration, and the rights and position of each party were determined through the logic and terminology of modern law. Here, not only the authority of the kattun, which had formed the basis of ritual practices, but also the authority of the deities who approved the adikara of the devotees was disregarded as being outside the modern judicial and executive systems.

In the ritual during the nēma, however, the people involved in the lawsuits became subordinate to the authority of, and the order derived from, the bütas through direct interaction with the deities. By participating in the exchange relationship with the deities, all the actors concerned in the event, including the parties to the lawsuits, came to recognise the deities as the supreme authority in the ritual. Consequently, the relations among the actors, which had been regulated by modern law, were converted into the mythological relationship based on the kattu and transaction with the deities. In this relationship, even though the members of the committee could have gained an advantage over the members of the guttus in the courts, they came under the authority of the guttus based on an ancient promise with the deities.

By making their promise to obey the kațụ and receiving blessings from the deities, the parties to the lawsuits became involved in the transactional network in which the deity is the supreme person. While still pursuing rights through modern law, they also reinforced the adikāra, the mythical rights and duties authorised by the deities.

\section{The complication of people's intentions and the evolution of disputes}

As seen in the last section, even while people were engaged in a legal dispute over shrine management, they were also subordinate to the divine and were repositioned in the customary transactional network in the büta ritual. The dispute over the village būta shrine thus transpires simultaneously in two realms, the court of law and the büta ritual, each manifesting its own values, logic, and power. In this section, I will investigate the dispute's transition between the realms more closely, focusing on the social positions and intentions of each actor concerned. As I will clarify, the transition process should 
be understood neither as a unilateral process of customary law's gradual disappearance after the advent of modern law nor as a process of customary law's subsumption under modern law and the exclusion of the deities' agency.

The series of conflicts examined in the previous sections points to how people have been groping to find a way to deal with the logics, systems, values, and resources recently introduced into their lives. For instance, as seen in the legalisation of shrine management and the foundation of the management committee, new systems based on modern logics such as legality, rationality, and democracy have spurred people to reform the old system. At the same time, with the advent of a new actor, N. Shetty, who had built a fortune in the city in the food service industry and then entered into shrine management, an unprecedented scale of capital was invested in the shrine, leading to its new economic value. As we will see below, the new logic and value have often conflicted with the traditional system in which the heads of guttus approved by the deities managed butta rituals using local resources, and this has caused various disputes and complications among the villagers.

\section{The expectation of democratisation and the development of the shrine}

As discussed, a series of issues arose when N. Shetty visited Perar and proposed financial support for the development of the village butta shrine. At first, Gangādara Rai, who was in charge of shrine management as the gaḍipatinārụ, embraced N. Shetty's plan and agreed with him. Gangādara Rai expected that he would offer sufficient funds for the renovation and reconstruction of the institution without changing the existing organisation and management. Meanwhile, what N. Shetty intended was not only to contribute to the development of the shrine as one of the devotees, but also to obtain management rights, authority, and honour as the top patron of the shrine. While persuading the heads of the higher-ranked guttus with his plan for shrine development, he gained villagers' support by proposing the democratisation of shrine management and the regularisation of payments for ritual servants.

Most of the villagers who came to be members of the committee had originally worked under the Mundabetțu guttu for the maintenance of the village shrine and preparation for the nēma. Among these villagers, some had complaints about the shrine management under the first and second guttu families. Some suspected that core members of the higher-ranked guttus had embezzled from the shrine endowments instead of distributing them fairly to the workers. In these circumstances, most villagers approved of $\mathrm{N}$. Shetty's proposal that ordinary villagers establish a committee to determine endowment use and shrine management systems.

The ritual servants' attitudes about this, however, were not uniform. For instance, Yatish Pambada and Jayānanda Pambada, the two main bùta 
dancers in Perar, illustrate contrasting attitudes towards N. Shetty's plan: while Yatish did not openly cooperate with N. Shetty and kept his distance from him, Jayānanda became close with N. Shetty and gradually came to be seen by others as being under his influence. It seems that Jayānanda accepted N. Shetty's plan because he was dissatisfied with the existing shrine management under the guttu families, and he expected to improve the status of the büta dancers and participate in decision-making concerning the treatment of ritual servants. Meanwhile, for N. Shetty, getting a leading Pambada dancer on his side was important for enabling him to intervene not only in shrine management but also in the ritual practice. As we will see below, however, Jayānanda, who had been regarded as being on the side of the newcomer in daily social relations, strongly affirmed the traditional ways of būta worship when he embodied the deity's agency in the ritual.

\section{The withdrawal of the guttu family from the shrine and the dilemma of a büta dancer}

As seen in the previous section, in the nēma in 2009, the tension between the Mundabețu guttu and the committee was arbitrated, and the traditional authority of the gadipatinārụ was temporarily recovered. N. Shetty, however, did not leave the shrine but continued to appeal to the Deputy Commissioner for the rights of the committee and to promote 'reform' for the shrine.

In November 2012, amid the unceasing tension between the two factions, the Deputy Commissioner ordered Gangādara Rai to hand over the key of the treasure house to the management committee. This decision deprived the Mundabețu guttu of its hereditary rights to the property of the shrine. In reaction to this order, the core members of the Mundabețu guttu immediately gathered at the main hall in the head house to discuss a suitable response. They also invited an astrologer to divine the future course of action. ${ }^{14}$ They received an oracle that the misfortune the Mundabețu guttu was suffering had been caused by the goddess Durga ${ }^{15}$ who had long been forgotten while dwelling in this house. According to the astrologer, in order to escape their misfortune, they had to worship the goddess properly in the head house and appease her anger. After a long discussion, they decided that all the members of the Mundiabetțu guttu family should withdraw from the management of, and ritual practice in, the village büta shrine, and instead concentrate on the worship of the goddess and deities in the head house. Gangādara Rai also declared that unless he could recover his dignity, he would never return to the shrine.

In February 2013, after this decision, the nēma was held at the village būta shrine without the members of the Mundabetțu guttu. In this nēma, N. Shetty took the place of Gangādara Rai as the chief patron and interacted with the possessed priests and mediums. In the ritual of the judgement, however, there was an incident of which N. Shetty had never dreamt. While Jayānanda Pambada was usually thought to be on the side of the committee, 
when he spoke an oracle as Pilicāmuṇụi in the ritual, he expressed outrage about the absence of the head of the first guttu and scolded N. Shetty in front of the devotees. Regarding this incident, a villager who knew of the close relationship between Jayānanda and N. Shetty said that the oracle must have really been spoken by the daiva.

We should consider several aspects of why Jayānanda, as the deity Pilicāmundi, gave the oracle that supported the traditional kattụ and ordered the reinstatement of the gadipatinārụ. As seen in Chapter 7, a būta medium is overwhelmed by the power of the deity and falls into trance just for a moment. After that moment, he acts as the deity while maintaining the dual perspective of the deity and himself. Needless to say, however, the real oracle is believed not to be the words of the medium, but to be the expression of the deity's will. In this case too, it is possible that the büta sakti filling the body of Jayānanda solely produced the oracle. At the same time, this incident can also be considered as a result of the entanglement of various powers, both social and spiritual.

In the ritual, Jayānanda spoke an oracle as Pilicāmuṇụi, with Balavāṇḍi incarnated in the mukkāldi. In daily social relations, Jayānanda Pambada is positioned under the mukkāldi, who belongs to the guttu family. In the relations among the deities in the village shrine too, compared to Balavāṇdi, Pilicāmuṇụi is regarded as a rather marginal deity. Bālākrishna Shetty, who plays the role of the mukkāldi, is one of the core members of the fifth guttu family and has consistently supported the Mundabețtu guttu in the dispute over shrine management. In addition, in ritual practice, Mukkāldi-Balavāṇụi has issued strong orders to devotees regarding the observance and recovery of the kattutu, and his words and deeds have gained him respect from the people as embodying the kattụ. Under these circumstances, in a ritual in which hundreds of people follow every move of the medium as the deity, it was almost impossible for Jayānanda-Pilicāmuṇ̣̣i to speak an oracle that completely contradicted that of Mukkāldi-Balavāṇụi. While in daily social relations he may have joined with $\mathrm{N}$. Shetty and strived to free himself from the conventional system of worship, in the ritual practice, affected by entangled forces - the wild sakti that enabled him to become the deity, the power of the mukkāldi as the powerful other, and the power of the people's gaze-Jayānanda was forced to act in line with these forces.

\section{The reconstruction of the shrine and confusion in the committee}

In 2013, N. Shetty launched the reconstruction of the village büta shrine. To raise funds for the construction work, he collected 5,000 rupees from each house and 500,000 rupees from each guttu house in Perar. He announced a large-scale plan to construct a brand-new shrine complex after demolishing all the existing buildings. The most prominent change in his plan was to move the Bramma guṇa, which had been regarded as the centre of the village būta shrine, outside the shrine precinct. According to N. Shetty, 
the reason why the gunda had to be relocated outside the shrine was that the deity enshrined in it was not the 'real' Bramma. He insisted that an astrological divination revealed that the linga enshrined in the gunda was not the embodiment of Bramma, but that of another deity called Śāstāvu Bramma. He therefore decided to move the existing statue and the entire gunda outside the precinct and to build a new shrine in which a new statue of Bramma would be enshrined.

The members of the higher-ranked guttus discussed this relocation plan with reference to the behind-the-scene circumstances and the lawsuit between L. Udupa and the Mundabețu guttu in the 1930s. In the lawsuit, as discussed above, the then asrānna L. Udupa who was also responsible for the daily ritual to Bramma asserted his trusteeship in the guṇa. Based on this past event, the guttu members conjectured that the real reason for the relocation of the gunda was that N. Shetty feared retaliation from B. Udupa, a descendant of L. Udupa who had been driven out of the shrine by the committee. In short, if the guṇa were located outside the precinct, it would be easier for N. Shetty to prevent interference from B. Udupa, who might also demand his rights in the guṇala. N. Shetty could then yield to him these rights only in the building outside the shrine. The guttu members' conjecture was therefore that the relocation must have been planned to prevent any future claims on the shrine from B. Udupa.

Meanwhile, as the construction work progressed under N. Shetty's command, splits were gradually appearing among the members of the committee. First, there were pent-up complaints about the compulsory collection of expensive donations among the villagers, including the committee members. Second, N. Shetty's arbitrary management of the committee added to their antipathy towards him. For instance, he proposed a new rule that would prohibit the Pūjāri workers from entering the shrine buildings, which as a matter of course antagonised the Püjāris. Third, soon after the construction work began, it was suspended because the workers' payments were overdue. Concerning this nonpayment of wages, some of the committee members requested that N. Shetty show the shrine's account book, but he refused.

Some of the committee members thus became estranged from N. Shetty, and around the same time, a rumour spread among the villagers that the newly enshrined statue of Bramma in the village büta shrine was shaking. This rumour soon led to the increasingly shared apprehension that the new statue was not appropriate for the village shrine. As we will see next, this phenomenon of the 'shaking Bramma' was a decisive factor in the estrangement of the villagers from N. Shetty, and it encouraged those who aimed to recover the rights of the guttu families.

\section{The astrological oracle and the return of the guttu family}

From the beginning of 2014, the members of the second guttu house as well as other villagers who anticipated that the committee's term of service 
would expire in April 2015 often visited the head house of the Mundabetțu guttu and asked for the return of Gangādara Rai. Responding to these persistent requests, the core members of the Mundabețtu guttu again organised an astrological ritual in the head house in September 2014. Through the ritual, they received an oracle from the astrologer:

It is not necessary for you to return to the village shrine. At present, however, the villagers are in a predicament. The difficulty was caused by the deities. The first and second guttu houses are the rulers of the whole village, and if the villagers have problems, you have to take responsibility for that. Therefore, you must go back to the shrine. If you do not take care of the villagers, the whole of your family will be punished by daiva.

This result was acceptable to the members of the Mundabetțu guttu because it recognised their right and duty to represent and protect the villagers under the approval of the deities, and encouraged them to return to the shrine. After some discussion among the core members, it was decided that Gangādara Rai and all the other members of the Mundabețtu guttu would return to the shrine in October. Regarding this, however, one of the core members of the guttu family told me: 'We cannot make this decision by ourselves. We should organise an astrological ritual, and only if we get permission [from the deities], can we go back to the shrine'. Gangādara Rai also expressed his attitude as follows: 'If our kutuma [matrilineal joint family] goes back to the shrine, I will also go back. If the kutuma people agree, I will return. However, I would never go back alone'.

When deciding whether they should go back to the village shrine or not, the members of the Mundabețtu guttu thus left the final decision to the agency of the deity, which was interpreted through astrology. The words of Gangādara Rai also indicate that even his decision as the head of the family depended on the decision of the kuțuma as a whole. As seen in the previous section, in the lawsuit over shrine rights, Gangādara Rai took part in the modern judiciary and appealed for his rights using its logic and terminology. At the same time, his words and deeds were always influenced by, and also depended on, the will of the whole family and the agency of the deities.

It can be pointed out that there is a duality not only in the attitude of Gangādara Rai, but also in those of the members of the Mundạbetțu guttu. Namely, while they engage in the dispute in the realm of the modern judiciary by using the whole family's human and material resources, for their final decision regarding their course of action, they depend on divine oracles and astrology. As we will see next, the villagers in Perar have shown a similar duality in their striving to discern a course of action in the conflict and confusion regarding shrine management and ritual practice. 


\section{The cursing goddess, shivering deity, and foundation of a new committee}

Soon after the Mundabetțu guttu family had decided to go back to the village shrine, a large-scale astrological ritual was held in the village būta shrine for nine days and nights, from 26 December 2014 to 3 January 2015. Some of the villagers contributed funds and organised the ritual to consult astrologers about the background and future of the dispute over the village büta shrine. In the course of this ritual, one astrologer delivered an oracle that surprised the participants: a goddess surrounded by rivers on three sides had cursed N. Shetty. In response, N. Shetty consulted another astrologer in hopes of contradicting this divination, but he could not receive any oracles that negated it. After a great deal of discussion and speculation about this oracle among the participants, they arrived at the conclusion that the goddess in question must be Durgā, as she was worshipped in the Mundabețu guttu house surrounded by a river and canals on three sides.

In addition, in this ritual, another oracle was delivered, namely, that the present asrāṇna was not suitable for the village shrine. Receiving this oracle, some of the villagers made noises about the possibility of the return of B. Udupa, who had left the shrine as a result of the conflict with the service committee. They received the following reply from him:

If I go back to the village shrine, it will be when even the shadow of $\mathrm{N}$. Shetty has disappeared from Perar. Above all, Bramma, which has been moved outside the shrine, must be brought back.

This reply from B. Udupa aroused discussion among the villagers about the rights and wrongs regarding the relocation of the Bramma gunda. In the long discussion, several villagers pointed out that the rumoured phenomenon of the new shaking Bramma statue might signify that relocation was not a good decision.

The ritual did not lead to a consensus among the villagers about how to solve the problems regarding the village būta shrine. Most villagers, however, came to take the astrological oracle and the shivering statue as warnings about the unsuitableness of various changes in the village shrine as well as the inadequacy of N. Shetty's leadership. As a result, this ritual decided the estrangement of most of the villagers from N. Shetty, and subsequently the dispute over the village büta shrine entered a new stage.

On 15 March 2015, about two months after the astrological ritual in the village būta shrine, a meeting was held in a small meeting hall in Mudu Perar. About 50 people participated in the meeting, including the mukkāldi Bālākrishna Shetty, an advocate who belonged to the Mundabetțu guttu, and other core members of the higher-ranked guttu houses. The main subject of this meeting was how they should manage the village būta shrine after the expiration of the present committee's term of service. Above all, 
discussion centred on the issue of how to deal with N. Shetty and his supporters, who would likely try to interfere in the establishment of the next committee: 'Should we stand up to N. Shetty's faction, or should we consult an astrologer again about our course of action?' 'First of all, do the daivas really need astrology?' After long and lively discussion, it was decided that interested villagers would collect contributions and organise another astrological ritual. It was also decided that they would establish a new society for social activities and register it at the Deputy Commissioner's Office. The society would be called 'Perara Sanskriti Protishtāna (Perar Cultural Committee)'. All the participants agreed that through this new committee, they would recover their rights in the village büta shrine and then establish a new system of management that, while based on the kațụ, would also be open to all villagers.

\section{Between the agency of deities and the power of modern law}

Focusing on the disputes over the village büta shrine in Perar, we have examined the entanglement of different logics and forces, such as customary law and modern law, and the agency of deities and the power of the judiciary, to clarify people's struggles to deal with these forces.

As seen in the first section, one of the main subjects in previous studies on Hindu temples in South India has been the institutional change of temples since colonial times. For instance, Appadurai (1981) and Dirks (1987) described the process of the decline of traditional kingship and the transformation of temples in accordance with the advent of a centralised bureaucracy and modern judiciary. The transformation process of Hindu temples is for the most part similar to the changes that butta shrines in South Kanara have seen. In line with the development of centralised administration for religious institutions, the būta shrine in Perar also became subject to management and control by the modern state and law. In this process, some people strived to acquire or enlarge their own rights and interests in the village büta shrine by using the modern judiciary. In response to villagers' demands for the redistribution or transference of rights in the village shrine and for the democratisation of shrine management, the members of the higher-ranked guttus, who had long occupied the status of trustees of the village butta shrine, were faced with the need to appeal for their rights in the shrine in terms of modern law.

At the same time, turning to the ritual practice in the village butta shrine, it becomes clear that we cannot presume the unilateral historical change described by previous studies, such as from the rule of the deity and king to control by the modern state and law, or from the ritual exchange of offerings and honours to the 'commoditisation of honours' and 'commercialisation of worship' (Dirks 1987, pp. 361, 383).

In the nēma and other būta rituals, people communicate with deities in various ways. Among these, the most important mode of communication 
is the transaction of offerings and blessings between devotees and deities. Through this transaction, the mutual rights and duties (adikāra) of both humans and deities are reconfirmed and the supreme power and authority of the deities is publicly recognised.

As seen in this chapter, both the Mundabețtu guttu family and the members of the committee participated in ritual transaction with the buttas. Through these transactions with the deities incarnated in mediums, they not only affirm the supreme power of the deities, but also become recipients of their agency. While engaged in the lawsuit over the rights and duties defined by modern law and approved by the judiciary, through ritual practice, they were all placed in the transactional network and came to act as those who bear the mythical adikāra that determine the relationship between humans and deities.

In relation to both the būta ritual and the courts, with their different manifestations of logic and power, the people involved have sought better positions and courses of action. Here, it is noteworthy that their practices almost always contain a duality, or entanglement, of activity and passivity, autonomy and heteronomy. In the ever-changing situation, the people concerned in the dispute, such as the guttu families, ritual servants, other villagers, and the committee members, all plan to maintain and enlarge their rights and interests, and sometimes act strategically. At the same time, on the verge of a difficult situation, they often depend on the oracles of deities and astrology as the basis for their decision-making. Acts and decisions based on the agency of deities, which temporarily appears in between the realms of jōga and māya, thus influence relations in, and processes of, disputes, and thereby generate further responses and transformations.

It should be noted, however, that it is overly schematic to view people as acting rationally and autonomously in the realm of the modern judiciary while acting passively and heteronomously in the realm of traditional worship. When participating in lawsuits, people are constrained by the various rules, customs, terminologies, and systems of the modern judiciary, and they strive to organise their modes of action in accordance with its strict logic and force. Likewise, in ritual practice, people strive to control their behaviour and shape their modes of action by following various rules and taboos called kattụ, norms and logics manifested in the oral epic, and, above all, the agency of the deities.

This is probably the reason why people often search in modern law and systems for ways to free themselves from the constraints and difficulties of customary law and systems, and yet at the same time, they return again and again to ritual practice to communicate with the būta śakti that directs their lives beyond any of the rules and restrictions of modern law and systems. While coming from different origins and histories, and embodying different values and logics, modern law and customary law thus appear to the people who relate themselves to both as deeply entangled, and even complemental, realms of power. 
The cases examined in this chapter thus cannot be understood as illustrating the mere process of new laws and systems which embody modern values and logics encompassing, changing, and surpassing traditional systems based on büta worship. They also cannot be interpreted as a process of the conservation and recovery of traditional laws and systems by avoiding modern influence. Rather, these cases show how people who have been involved in entanglements of, and conflicts between, the modern judiciary and büta worship reorganise their relationships with others and recreate their modes of life, not only by following, but also by utilising the respective power of modern law and deities. This point will be considered again in the succeeding chapters, as part of the investigation of people's practices under large-scale social changes such as the reorganisation of the matrilineal system and land tenure, the implementation of land reforms, and the advent of a massive development project.

\section{Notes}

1 See, for instance, Appadurai and Breckenridge (1976), Appadurai (1981), Fuller (1984), Presler (1987), and Dirks (1987).

2 Fuller (2003), however, carried out a follow-up survey on the same temple and clarified that the traditionalism of priests and authority of the temple had actually increased under state policy.

3 On the juristic personality of Hindu deities in terms of religious endowments, see Sontheimer (1965).

4 On the gift-exchange relationship in Hindu society which does not form a closed cycle, see Parry (1986).

5 In Tulu, darșana indicates vision or sight, and also means trembling due to possession by deities. See Upadhyaya (1988-1997, p. 1571).

6 Regarding the issue of agency manifested through interactions between humans and deities, see also Gell (1997), Pinney (2001), and Ishii (2014a).

7 On the participation of government officials in Hindu rituals in temples, see Appadurai (1981, p. 49) and Fuller (1984, pp. 76-77).

8 Because the village butta shrine was located in Padu Perar, the institution was called 'the Padu Perar institution' in the court record.

9 Under the HRE Act, 'hereditary' temples (that is, temples whose managers had not previously been selected by government officers) were seen as private institutions and were thus relatively free from any direct outside control. The 'excepted' temple category was abolished in 1959 (see Presler 1987, pp. 24, 48).

10 The dispute between the asrānna and the higher-ranked guttu houses over the management of the village būta shrine continued intermittently. In 1960, a judgement was given that dismissed the asrānna's rights in the village büta shrine, except for his right in the gundia (O.S. No. 25 of 1960).

11 In principle, Deputy Commissioner of the Dakshina Kannada district serves concurrently as Deputy Commissioner for Hindu Religious Institutions and Charitable Endowments and executes his duties under the Commissioner.

12 'Law CR [Court Records] No. 7/2002-2003' indicates the original order by which the Deputy Commissioner appointed N. Shetty as the fit person for the shrine management in January 2003. It is also the title of the body of documents about the disputes regarding this order.

13 The Madras Hindu Religious and Charitable Endowments Act, 1951 had been in force until the Hindu Religious Institutions and Charitable Endowments Act came into force in May 2003. See Presler (1987, p. 28, note 32). 
134 Social transformations, emergence of new umwelt

14 People in South Kanara often invite astrologers from Kerala who belong to the community called Poduvāl. This time too the Muṇabetțu guttu family invited famous astrologers from Kerala, and in addition to the expenditure for the ritual, the family had to pay all the expenses for their travel and stay in Mangaluru. On Poduvāl, see also Thurston (1975[1909d]), pp. 203-205).

15 Durga is one of the great Hindu goddesses, who is believed to be the wife of the god Shiva and to be a dreadful warrior who kills demons. 


\section{Historical changes in land tenure in South Kanara}

As I discussed in Part One, people involved in būta worship in South Kanara consider the deities not just as objects of worship in shrines, but as circulating power that link the realm of the wild and the realm of the human. The būta śakti enables the continuance and reproduction of people's everyday life by constantly changing its form as it flows through the mountains, fields, village houses, and shrines, bringing fertility to the land and prosperity to the families. However, though the būta śakti brings about fecundity, it is at the same time dangerous; hence, the people must direct its flow through ritual, and adjust their relationship with the realm of the wild. They need to keep placating the dangerous power by offering the products of the land they cultivate in return for receiving the fertile power of the wild.

Oral epics and rituals in Perar express such relationships between the people, land and nature, and deities. In the păddana, the mythic origin of ritual is chanted, recounting how Balavāṇ̣i and other būtas demanded that the guttu houses should worship them in exchange for rights to control the village land. Through the exchange of offerings and blessings between the guttu heads and deities, the nēma also re-enacts a mythical drama in which the deities demand the performance of rituals and grant the guttu heads adikāra to the land and its people. The guttus' control and rights over village land are thus renewed through rituals. At the same time, the people reaffirm the fact that such rights are transitory and impossible to attain without the deities' acknowledgement. It is the butas dwelling deep in the forests as the ultimate 'owners of the land' who rule over agricultural fields, forests, houses, and products of the land in Perar. The people only receive transient rights by offering rituals to the deities and appeasing them.

Būta rituals have been the basis of land use and holding, as well as production and distribution of agricultural products in village society. At the same time, the continuation of such rituals has been supported by the traditional land tenure system by which guttus who ruled over vast areas of land managed the shrine, and distributed land and products according to the ritual status of each family. As we will see in Chapters 10, the maintenance and succession of büta rituals and land tenure among the guttus, constituted mainly by the Banta, was possible due to the traditional matrilineal system called aliyasantāna kațț̣. 
Land in South Kanara was an important source of income for the state and government of the region from the pre-colonial period to the present day. Moreover, it has been a significant target of public policy since land was the key to rule and governance over the local people whose livelihood depended on farming. Therefore, land has continued to be the site where the logic, values, and power of public policy and law meet, compete, interact with, and mutually influence the logic, values, and power shaped by customary relationships between people. In this process, the people have crafted many imaginative and conflicting practices to modify their relationships with land, nature, and others to the various new institutions that demanded the reassembling of and changes in customary relationships.

In this chapter, I will look at the historical development of land tenure in South Kanara from the pre-colonial era to the period of land reforms after independence. This will set the context for understanding people's practices in dealing with changes in public policies over land by focusing on their relationship with büta rituals in subsequent chapters. I will first give an outline of the land tenure system in South Kanara based on historical sources. Next, I will focus on the introduction of the ryotwari system in the colonial period and analyse the characteristics of the system in South Kanara. I will then examine the official documents published in the early twentieth century on land tax assessment and the registration of landholders ( pattadār) in Perar. ${ }^{1}$ The results of this analysis will show that not only did the existing landlords took on the role of pațtadārs, but the traditional kinship system based on matriliny was also applied to the new land tenure system. I will deal with this matter in more detail in the subsequent chapters. Last, I will present an outline of the effects of land reform in South Kanara based on previous studies as a background to what I will discuss in Chapter 11.

\section{Land tenure in pre-colonial South Kanara}

The history of South Kanara before British colonial rule may be divided roughly into four periods: Allupa period (around sixth century to end of fourteenth century); ${ }^{2}$ Vijayanagara period (mid-fourteenth century to seventeenth century); period of Keladi Nāyakas (early seventeenth century to eighteenth century); ${ }^{3}$ period of Hyder Ali and Tipu Sultan (1763-1799) (Ramesh 1970; Abhishankar 1973, pp. 33-85).

Ramesh analyses the history of South Kanara based on inscriptions on stone and copper plates (Ramesh 1970, p. xvii). He classifies inscriptions from the mid-seventh century to the Battle of Rakkasa-Tangadi in 1565 as follows: early Âlupa period (mid-seventh century to mid-tenth century); midto late-Ālupa, Hoysaḷa period (968 to late fourteenth century); Vijayanagara period (1345-1565). I will give an outline of land tenure and socio-economic conditions of South Kanara in the Âlupa and Vijayanagara periods based mostly on Ramesh's work. ${ }^{4}$ 


\section{Land tenure in the Allupa period}

We do not have much evidence about the everyday lives of people in South Kanara before the early Âlupa period. According to Ramesh, it is written in an inscription of the mid-seventh century that South Kanara was ruled by Āluvarasa, and Āluva or Ālupa appears as names of the royal family in later inscriptions. South Kanara was predominantly agricultural since early times, and land wealth was called $b \bar{a} l u$, which meant life and subsistence. Land was owned not only by royalty but also by private citizens. In early Ālupa period, the king's land was bestowed on temples, Brahman priests, private citizens, and warriors. The royal family also collected taxes on paddy, rice, pepper, cotton, and areca nuts (Ramesh 1970, pp. 269-272).

By the mid- to late-Ālupa period, the word bālu became a synonym for land wealth. In this period, names of measuring vessels of agricultural products (mudi) and terms relating to land tenure used in present-day South Kanara began to appear in the inscriptions. For example, genni referred to land tenancy or rent paid to the landholder by the tenant, ${ }^{5}$ and müliga referred to farmers who permanently borrowed cultivable land from land owners (Ramesh 1970, pp. 275-276). The people subsisted mainly on agriculture, and land and its products were the major source of income for the royal family. Many kinds of taxes were levied on land, its products, and trade in this period. According to the inscriptions of the period, it was the duty of the villages to pay tax in cash to the royal treasury. These taxes were called samudāya, which meant collective tax or contribution. Landholders and farmers also paid a part of the products of the land to the royal treasury as tax. Landholders paid tax on land ownership in cash. This tax was called bhukti samudāya from the word bhukti meaning 'enjoyment' and 'ownership'. Various plots of cultivable land were also taxed (Ramesh 1970, pp. 277-278).

From the above description, we see that land was a valuable resource for people's livelihood during the Âlupa period. We also see that the state levied various taxes on land and its products as a major source of income.

\section{System of land tenure in the Vijayanagara period}

During the period of Vijayanagara rule, South Kanara was divided into two parts, Bārakūru rājya and Mañgạ̣ūu rājya, each region being governed by a ruler appointed by the kingdom. Most of the areas, however, were under the rule of local chiefs (Ramesh 1970, p. 279). As the Ālupa royal family declined and the Vijayanagara kingdom came to dominate, there was a rise of many families of local Jain rulers in South Kanara. These families ruled over each region as landlords, and at the same time seemed to have contributed to the spread of the matrilineal system (aliya santāna kațtụ) in South Kanara. According to Ramesh, there are no records of an inheritance system other than that from the father to son in South Kanara until the mid-thirteenth century. The Âlupa royal family had not practised the aliya santāna system of inheritance from 
mother's brother to sister's son. However, the Jain rulers generally followed the matrilineal system; hence, their emergence appears to have led to the spread of this system in South Kanara (Ramesh 1970, pp. 279-281). ${ }^{6}$

Commerce developed in South Kanara in the Vijayanagara period. Several merchant guilds, including sețtikāra, were established in many cities. Some agricultural products were imported from beyond the Ghats. Since the growth of trade made the merchants rich, according to records of the Vijayanagara period, the merchants and their guilds became significant donors of cash and land to temples, along with the rulers of the kingdom (Ramesh 1970, pp. 283-284).

However, rights to land tenure and cultivation in this period were almost the same as those in the Ālupa period. In many cases, the state owned the villages and the cultivable land affiliated to them, which are described as bhandāara-sthala and aramanege saluva bhandāra-sthala in the inscriptions. Land owned by temples and private citizens was called differently according to who the owners were. In this period too, land tax constituted the major income of the state treasury. In the inscriptions of the Vijayanagara period, there are descriptions of many kinds of land and land tax, including the main ones in the Ālupa period.

Ramesh lists several kinds of land, landowners, agricultural workers, and taxes that appear in the inscriptions (Ramesh 1970, pp. 284-287). The richness of the vocabulary referring to land and taxes indicates the importance of land policies and affluence of the tax system of this period. In fact, as Ramesh points out, there was a great development in land policies of South Kanara in the Vijayanagara period. Income from land tax was re-evaluated from time to time, and buying and selling of land was governed by administrative rules. The borders ( $g a d i$ ) of plots owned by temples, individuals, and guild organisations were fixed (Ramesh 1970, pp. 287-288). ${ }^{7}$

From this, we have a glimpse of the socio-economic conditions in South Kanara, the administration of land in particular, in the Vijayanagara period. Taxation and land management became more institutionalised during this time compared with the Allupa period. But each region in South Kanara was related to the centre through the rule of chieftains, rather than being directly under the control of the central government (cf. Karashima 1994). The presence of Jain landlords who exercised control at the local level in South Kanara in this period and the establishment of administrative areas related to taxation are particularly significant in relation to būta rituals. I will discuss this in the next section by referring to the work of Gowda (2005).

\section{Administrative system and būta rituals in the Vijayanagara period}

Gowda investigates the institutionalisation of būta rituals in South Kanara in relation to the administrative system of the Vijayanagara period (Gowda 2005, pp. 17-38). He points out that various regions in South Kanara were placed under the administrative system of the central government. 
The inscriptions of the period include references to names of administrative units, such as dēśa, rājya, nāạu, sìme, māgaṇe, grāma, ūru, cāvaḍi, and guttu. Rājya, nāḍu, and sīme were larger administrative units, while māgaṇe, which constituted a part of nāḍu or sīme, was a medium-sized unit consisting of several grāmas. Grāma was a unit consisting of several villages and $\bar{u} r u$ was a settlement inhabited by several families (okkalu). The units were hierarchically ordered from largest, rājya (or dēśa, maṇdala ), to the smallest, okkalu (Gowda 2005, pp. 27-28). Guttu functioned as an administrative unit as well as an economic one. A village usually contained four to eight traditional guttus, and the head of a guttu was responsible for collecting and paying a fixed amount of tax to the state treasury. Village administrative organisations included grāma, jagattu, and mukkāldi, and village administrative officers were known by titles such as grämani and madhyastha. ${ }^{8}$

If we compare the administrative system in South Kanara during the Vijayanagara period to the system of būta worship, we see that they are correlated. Gowda points out that būtas can be classified according to their power in the region as follows: Būtas of sīme (or nāḍu); būtas of māgane; būtas of grāma; būtas of ūru (village); būtas of guttu; and būtas of kuṭuma (family) (Gowda 2005, pp. 29-30). In būta rituals, sīme as a whole was under the control of arasu būtas or sīme būtas, which were called the 'royal būtas' (Gowda 2005, p. 30). All būtas below the māgane būtas were subordinate to sīme būtas, and had jurisdiction over their respective geographical areas, such as māgaṇe, grāma, and guttu. In this way, in principle, the power of the bütas was geographically constrained and there was a hierarchy of būtas with sīme būtas at the top, just as in the administrative system of the Vijayanagara period.

A correlation between the Vijayanagara administrative system and buta rituals can also be seen in the names and roles of the bütas. The king of sīme in the Vijayanagara period was known as 'king over two hundred people (innūrāla arasu)' and 'king over one thousand people (sāvirāla arasu)'. The same kind of names were used to refer to būtas, for example, Panjūrli būta was often called the 'Panjūrli of a thousand people'. Būtas were said to have royal jurisdiction ( patta) in ritual contexts.

From the above facts, Gowda concludes that the buttas upheld the existent hierarchical administrative system and its authority, and functioned as its advocate in būta rituals such as nēma and kōla. Hence it can be said that būta rituals functioned to maintain and reproduce the administrative system in ritual contexts in South Kanara in the Vijayanagara period. Politico-economic authority and land ownership rested in the hands of the rulers and landlords in South Kanara up to the twentieth century, and the development of büta rituals was closely linked to its history (Gowda 2005, p. 31).

If we combine the insights of the research by Ramesh and Gowda, we see the possibility of a close connection between the organisation of büta rituals and the establishment of administrative divisions and landlords' rule over land in the Vijayanagara period. As I have already mentioned, land policy in 
South Kanara greatly developed during the Vijayanagara period, and various regions were ordered in a hierarchy of territories from the uppermost sìme, a little kingdom ruled by a local king, to guttu, the domain of the village landlord. Some of the rulers of sime seemed to have been Jains who had become prominent in South Kanara during the Vijayanagara period. In this period, būta rituals were ordered to correlate with the administrative and geographical units, and had jurisdiction over local society along with the heads of administrative units. The highest in rank were the king and the būta of sìme, and at the bottom of the hierarchy were the family head and its būta.

Oral epics (pādddana) narrating the origin of būta rituals reflect this history. As we saw in Chapter 4, according to oral epics, royal būtas were first welcomed in Perar by Koratāi Balardi, a female head of Jain guttu family, who built a shrine and began the būta worship. It is said that the büta ritual and the status of guttu were inherited by a Banta family through the brother and sister she adopted. Balavāṇ ḍi of Perar begs a būta called Arasu, that is to say, the būta king corresponding to the sīme king, and invites him to Perar. By comparing the contents of such oral epics with the history of South Kanara in the Vijayanagara period, we may presume that būtas came to take on governing roles as they were coupled with their respective administrative units, namely small states governed by Jain rulers and local societies of different scales, such as grāma and ūru. This process promoted the organisation and hierarchy of būta rituals.

We should also consider why it was the būtas that came to complement the administrative system and the landlords' authority in South Kanara. It is not easy to give a definitive answer to this question, but it may be because the butas were widely worshipped as indigenous deities strongly linked to nature and particular lands, and were the 'owners of the land' who determined the fertility and productivity of the region. Incorporating deities that were considered to be the ultimate 'owner' and basis of the land and its products into the administrative system based on land tax, and correlating the head of administrative unit with the büta at each level, made it possible to legitimise political rule over land and those who cultivated the land as having the blessings and acknowledgement of the deities.

However, we should note that the relationship between būtas and humans cannot be reduced to such a functional interpretation. As we saw in Part One, būta rituals not only grant the guttus legitimacy but also destabilise the authority of the devotees, including that of the guttus, by making the people aware of the supreme authority of the būta itself. The correlation between būta rituals and administrative systems mentioned by Gowda thus should not be understood merely in terms of the political use of būta rituals by the rulers. That is to say, the linking of the system of governance and büta rituals does not imply an absolute domestication or institutionalisation of the latter. Rather, it is a process whereby the wild śakti penetrates the realm of politics and becomes the source of political power. 
As I have discussed so far, in South Kanara in the Vijayanagara period, the authority and power of būtas were hierarchically organised correlating with the establishment of administrative units. Systems of political, legal, and religious rule were formed at the level of village society, and land and families were organised under this system. Also during this period, there was probably a hierarchical ordering of families devoted to the village buta shrine, as well as distribution of grants and agricultural products according to the status and role of each family.

As I have already mentioned, in Perar, there was a hierarchical ordering of the main families centred on the guttu families and the village buta shrine. There was a system whereby each family was given land belonging to the shrine and a part of agricultural products along with the buta's blessings. The heads of guttu families not only ruled the village society based on their land ownership, but also were in charge of distributing the products of and rights to the land. Central to this distribution process were the 'rājanụ daiva', who owned vast amounts of land as shrine wealth, accumulated local products as offerings, and controlled the redistribution of land and its products through the guttu heads. ${ }^{9}$

\section{Land policy in South Kanara in the colonial period}

\section{Land system in the Keladi Nāyaka period}

In this section, I discuss the land policy in South Kanara during the colonial period. Before I do so, let me give a brief account of the conditions in South Kanara from the seventeenth century to the end of eighteenth century, the period of transition from Keḷadi Nāyaka to British rule.

South Kanara was ruled by the Keḷadi Nāyakas from the early seventeenth century to $1763 .{ }^{10}$ Historical records of land policy of this period, however, are insufficient (Stein 1989, p. 71). Madhava analyses religious organisation and land tenure in coastal South Kanara from the late Vijayanagara period to the Keladi Nāyaka period by using primary sources including inscriptions (Madhava 1985). He notes that the ruling classes and wealthy citizens donated land to religious institutions in South Kanara during this period. Transfer of land was made in the deity's name and the deity held proprietary rights. This was known as déva patte, and donated land (pattil) was usually exempted from tax.

Many inscriptions refer to land transfers called inām, umbali and uttāra. Umbali was essentially land for the purpose of self-sufficiency. Uttāra referred to land that was a source of income for special use such as for ritual purposes. The person managing the religious institution at the time was said to have often appealed to the ruler for the transfer of uttāra (Madhava 1985, pp. 133-134). As we saw in Chapter 2, the families of workers (cākiridakulu) serving the village būta shrine in Perar were given land called umbali. Based on Madhava's research, we can assume that such land was for the purposes 
of self-sufficiency and was transferred to various families tax-free in lieu of services they offered to the büta shrines.

What is interesting about such land donations is that the ruling classes and individuals sometimes donated land they purchased from the original holders to religious institutions. In such cases, religious institutions were given the original rights to the land by paying the donors some money. Those in positions of authority in the religious institutions also personally bought and sold land. In such cases, they were able to buy new land by paying tax called kannike to the state treasury. It was also possible to mortgage and rent donated land to tenants. Rulers of coastal South Kanara donated land to religious institutions and at the same time had an income by collecting taxes from them. There were also cases of rulers interfering in the use of the land they donated (Madhava 1985, pp. 133-142).

In this way, in South Kanara during the period of Keladi Nāyakas, land was an important medium for linking the ruling classes with the ordinary people through donations and transfer. Land was also subject to sale and rent, and an important source of income for religious institutions. ${ }^{11}$

\section{Introduction of the ryotwari system by Munro}

In 1763, Hyder Ali defeated the Keladi Nāyakas and occupied South Kanara. After the war of 1767, Hyder Ali and Tipu Sultan fought many wars against the British. When Hyder Ali died in 1782, Tipu Sultan, his successor, defeated the local chiefs of the region except for the southernmost area. Tipu Sultan died fighting the Fourth Battle of Mysore in 1799, and South Kanara came under British rule (Abhishankar 1973, pp. 4-5, 61-65). Since then the land policy of South Kanara entered a new phase.

Many British, including Thomas Munro and John Sturrock, who governed South Kanara, refer to the brutality and exaction of Hyder Ali and Tipu Sultan resulting in the ruin of the region and poverty of the landlords. According to the historian Rao, who examines the discourses of colonial administrators in nineteenth-century South Kanara, the British often mention 'the destructive performances of the Mysore rulers' in South Kanara and Malabar (Rao 1991, pp. 64-65). It was part of the British administrator's mission to restore the 'wise and liberal institutions of the antient (sic) Hindoo government' (Stein 1989, p. 67) ${ }^{12}$ destroyed by the 'rapacious Mysorean rule' (Stein 1989, p. 67). In spite of the brevity of his term in Kanara, ${ }^{13}$ Thomas Munro, who drafted and headed the taxation system in the region, also proposed the land tenure system in the Vijayanagara period as the ideal.

Thomas Munro was appointed as the first collector when Kanara came under British rule in 1799. He worked on assessing land tax and establishing a taxation system for around 15 months until he was appointed as the collector of the Ceded Districts in October of the following year (Stein 1989, p. 64). I will first give a brief account of Munro's work in Kanara and its evaluation at the time based on the writings of Arbuthnot (1889). Next, I will 
analyse the land policy in colonial Kanara based on Stein's research (1989), which questions the predominant view of Munro by a critical reading of the existing material about him.

According to Arbuthnot, the land of Kanara, which had been prosperous with lower taxes than other regions in the past, was in a state of anarchy and confusion due to having been 'grievously oppressed by the exactions of Hyder and Tipoo' (Arbuthnot 1889, p. 55) by the time Munro took office as the collector (Arbuthnot 1889, pp. 55-56; see also Stein 1989, pp. 64-65). Munro was thus faced with the difficult task of recovering order and establishing a taxation system, but he was adamant in creating a system which was to become the basis of a tax system in Kanara. Munro traced the records on systems of land tenure and tax assessment dating back to the mid-fourteenth century when Kanara was under Vijayanagara rule. He thought the system of assessment introduced in this period was valid for his purposes (Arbuthnot 1889, p. 58; see also Beaglehole 1966, pp. 46-47).

Arbuthnot points out that taxes in the Keladi Nāyaka period were reasonable, as it did not go over a quarter of the total products. After Hyder Ali conquered Kanara, however, people suffered due to heavy taxes and oppression. Land in Kanara was originally considered as private property and there were no restrictions placed on land transfer through sale. Many land owners used tenants but these tenants had more or less permanent possession. Moreover, most of the land in Kanara had high sale value. However, this situation was changed during the rule of Hyder and Tipu. Many of the old landlords were annihilated and rights of landholders were restricted. According to Munro, however, the rights that endured were 'still as much cherished, and the title to it as obstinately contested, as it ever was perhaps at any former period' (Arbuthnot 1889, p. 60).

The land tenure and tax system promoted by Munro in Kanara was the ryotwari system. This was a system by which taxes were collected from owners of small plots without the intervention of any form of intermediaries, such as zamindars. ${ }^{14}$ Ota's research focuses on Baramahar where the assessment method based on the ideas of the ryotwari system by Alexander Read and Munro was first introduced in South India (Ota 1994). Ota points out that under this system all land was owned by the state, and peasants who used the land were all considered to be tenants, who signed a contract with the state individually every year and were obliged to pay a fixed amount of land tax per parcel. That is to say, there were three characteristics of the ryotwari system: land ownership by the state, individual liability of land tax, and exclusion of intermediaries for tax collection (Ota 1994, p. 223; see also Mizushima 1999, pp. 443-445).

According to Ota, the ryotwari system was formed essentially to adapt to the natural environment and agricultural conditions of the dry region of Baramahar. In late eighteenth-century Baramahar, land had little significance in agricultural production and did not have commodity value. Ties between peasants and land were weak, and there was a high rate of spatial 
and social mobility. Under such conditions, it was reasonable to have a system of state land ownership where tax was levied only on land cultivated each year. However, it goes without saying that the situation in Baramahar differed from that in Kanara, which was a pluvial region where land was highly valued and old landlord classes were prominent.

The ryotwari system introduced in Kanara by Munro was appropriate for the kind of land use in Kanara, so it differed from the system introduced in Baramahar. Arbuthnot points out two characteristics of the ryotwari system in Kanara. First, in many cases, land tax was to be paid not by the actual cultivator, but by the landlord who used tenants and collected rent, and by those who had semi-permanent land rights. Second, the amount of tax assessed was not based on each plot of farmland but on each estate or warg (Arbuthnot 1889, p. 62; Sturrock 1894, p. 118; Mukherjee 1962, p. 17; Bhat 1998, pp. 90-91). Estates referred to by Arbuthnot as warg originally meant the leaf that was used for land records by the Vijayanagara government. ${ }^{15}$ It later came to refer to the collection of several plots of land owned by one family recorded on these leaves. The landholder was called wargdār or mülawargdār meaning 'original or hereditary holder' (Baden-Powell 1990 [1892], p. 147). ${ }^{16}$

Such methods of land assessment and taxation were suited to land use in Kanara where a landlord owned several plots scattered in various places and tenants cultivated some parts of them. Thus, it was possible to assess and collect land tax without introducing major changes in the existing form of land use. Arbuthnot interprets this as a result of Munro's respect for the local system of land use (Arbuthnot 1889, p. 62; see also Beaglehole 1966, pp. 8-9). Arbuthnot argues that Munro's tax policy accepted the existing local system and did not introduce changes that were deemed unnecessary. Munro discovered 'a very widely established system of private property in land' (Arbuthnot 1889, p. 62) in Kanara, and tried to reconstruct a system that was valued by the local people, and to strengthen it, instead of replacing it with a new system. He strongly opposed the demands made by the Madras government to submit a plan to divide the region into large-scale estates so that the principles of Bengali zamindari system can be applied. Munro argued that all kinds of land in Kanara were considered as private property and a significant value was attached to land and its title deed; therefore, it would not be possible to divide Kanara into large-scale estates and collect land taxes from a small number of large-scale landlords, unless all the rights of existing landlords were annihilated (Arbuthnot 1889, pp. 62-63).

The sociologist, Damle, presents a different view from Arbuthnot of the ryotwari system introduced in Kanara by Munro. Damle points out that the ryotwari system was introduced in South Kanara without surveying the plots. ${ }^{17}$ Several plots, the size of which were unknown and often located in different places and villages, formed a holding called warg. These holdings were not marked with borders appropriate for the ryotwari system, and ownership rights of any size of land were permitted if the landholder agreed 
to pay the amount of tax assessed by the government. Damle argues that Munro levied tax not on farmland but on warg without changing the size of the holding. Hence the ryotwari system did not change the existing system of land tenure or lead to new rights. In other words, the position of landlords as patțadār was strengthened as the existing form of land holding was institutionalised (Damle 1991, pp. 147-148).

We gain an insight into the characteristics of the ryotwari system in Kanara from the accounts of Arbuthnot and Damle, though they differ in that the former views Munro's policy in a positive light while the latter is critical of it. The ryotwari system introduced in Kanara differed from that in Baramahar. It suited the conditions of existing land tenure in Kanara as land tax was levied on warg consisting of several plots, and the warg holders were made to pay land tax. Thus, the rights of existing landlords were not lost due to introduction of this system. In fact, as Damle points out, the status of the old landlords may have been strengthened by the institutionalisation of the customary form of land holding. As we saw in the previous section, village landlords had holdings at the village level in the Vijayanagara period. We could say that several plots owned by such landlord families came to be established as warg, and the family head (or the representative of the sub-group of entire family, which I will mention later) became the patțadār. ${ }^{18}$

\section{Munro's intentions and the 'invention of tradition'}

What kind of logic did Munro employ to proceed with the introduction of land policy and new system in Kanara? Stein analyses this by looking at Munro's use of historical sources (Stein 1989). Stein points out that Munro submitted reports about Kanara to the Madras government on two occasions, on 31 May and 19 November 1800. In the report submitted in May, Munro argued that individual, private property in land dated back to ancient India. His claim was based on the view that Harihara, the king of Vijayanagara, had created a system of assessment in fourteenth-century Kanara in accordance with ancient Hindu texts (Stein 1989, p. 66).

About six months later, in the report of November 1800, Munro focused on the importance of private property rights and the large number of lawsuits over land in Kanara at the time rather than on historical sources. He took pains to respond to the request of the Madras government to introduce land and tax system in Kanara following the example of the Bengali zamindari system. As we have already seen in Arbuthnot's account (1889, pp. 63-64), Munro argued against the government's request, pointing out that since there were already private land holdings, and validity of land title deeds was debated in law courts in Kanara, it would be impossible to create large-scale holdings and landlords without annulling the rights of existing landlords. Munro pointed out the value of small-scale holdings in Kanara, and if the government were to proceed in creating large-scale holdings, 
these holdings should adhere to the existing social and community borders. He contended as follows:

The most convenient arrangement would be the ancient one of maganies or gramams ... To break in upon ancient boundaries and landmarks for the sake of ... squaring estates, would occasion much trouble ... because these boundaries serve not only to divide lands, but also particular tribes or families who form distinct communities in their respective villages.

$(\text { Stein 1989, p. 67) })^{19}$

Stein points out that such statements by Munro could have dislodged his own logical basis for promoting the introduction of the ryotwari system. The claim that there were communities in local society weakened Munro's claim about the ryotwari system based on agreement between the state and individual peasants. Moreover, references to 'distinct communities' (Stein 1989, p. 67) and land holdings cast doubts over Munro's theory of there being small-scale private property ownership by individuals. In spite of such risky argumentation, Munro's report gained the support of high officials in the Madras government, and in 1804 the Court of Directors of the East India Company expressed their appreciation of Munro's achievements in extracting land tax records of the past 400 years based on ancient historical sources.

However, Munro's 'historical' reconstruction of ancient tax system, according to Stein, was in fact nothing more than a conjecture based on extremely vague evidence. In his report of May 1800, Munro said that village accountants in Kanara kept records of land holdings and transfers, and 'black books (kaddatams)' (Sturrock 1894, p. 95) with revenue reports over several centuries. He stated that many of these black books were lost during the rule of Hyder and Tipu, but enough of them remained to understand the tax system of 400 years. Munro also claimed that according to ancient tradition and descriptions, all cultivable land was privately owned and land owned or rented by the state was unclaimed waste. He pointed out that there was no land tax before the rule of King Harihara of Vijayanagara, and it was after the reign of King Harihara that a system of dividing the products of the land between the landlords, cultivators, and the government began. He saw this as the standard for land tax in Kanara.

Stein argues that such claims by Munro were not historically verified. Only Sturrock, one of Munro's successors in Kanara, queried the existence of the 'black book' on which Munro's theory depended, and hinted that Munro could not have reconstructed the tax rates of the time due to lack of historical sources on areas of cultivated land and currency value of the Vijayanagara period (Sturrock 1894, pp. 95-96; Stein 1989, pp. 67-70).

Stein critically analyses Munro's hypothesis based on the historiography of medieval Kanara by Ramesh (1970) and Bhatt (1975). Stein argues that these historical studies do not support any of Munro's hypotheses. First, as 
opposed to Munro's theory on the transformation of the land tax system under the Vijayanagara kingdom, in Stein's view, the expansion of Vijayanagara power had almost no administrative influence in the coastal region. Stein points out that the ruling authority of chiefs from the olden days continued in Kanara in this period. These chiefs included the matrilineal Jains, and they maintained political independence from the Vijayanagara administrative system. There was also continuity of a village administrative system based on warriors and community of farmers. Second, whereas Munro argues that there were no state-held lands in the Vijayanagara period and periods preceding it, historical research of the medieval period refers to land that was taxed at the government level (bhanḍāra-sthaḷa). ${ }^{20}$ Third, Munro's theory suggests that the land administration system introduced by the Vijayanagara rulers was fundamentally changed by the Keladi Nāyakas, but historical research points out that there are very few sources about the land policy in the Keladi kingdom and Munro's claims cannot be substantiated. ${ }^{21}$ Stein thus argues that 'Munro's "historical" reconstruction of Kanara's land-revenue system was deceptive' (Stein 1989, p. 71). Munro had created a history in order to legitimise the level of tax assessment in the region he managed and collect taxes without resistance from the old dominant landholders (Stein 1989, pp. 70-71).

Stein's critique of Munro's report seems partly correct. Munro placed importance on avoiding resistance and confusion among the landholders of Kanara at the time when introducing new land and tax policies. For this purpose, he came up with the idea of introducing the ryotwari system that suited the existing form of land use/holding; and he tried to legitimise the introduction of this system by referring to the 'accounts and traditions' (Stein 1989, p. 66) of the Vijayanagara period. He set up the warg as the unit of taxation, made the warg holder the tax payer, presented the tax system of the Vijayanagara period as the model for land policy, and stressed the importance of existing boundaries and system of land tenure.

There are, however, some points in Stein's critique of Munro's hypotheses that do not seem appropriate. One is Stein's view of 'political independence' (Stein 1989, p. 70) of chiefs in the Vijayanagara period. Ramesh's historical research indeed refers to the emergence of local rulers in South Kanara in the Vijayanagara period. However, we cannot infer from this that such rulers were politically independent from the Vijayanagara kingdom. Rather, we see how the rulers of the kingdom and its citizens were linked through the people's allegiance to local rulers (Ramesh 1970, p. 279). Moreover, Ramesh's research makes it clear that the land tax system greatly developed during the Vijayanagara period (Ramesh 1970, p. 287), in contrast to Stein's view that the Vijayanagara kingdom had little administrative influence in the coastal areas.

The ryotwari system in Kanara was designed for a stable collection of tax, without taking away the rights of existing landholders, and avoiding resistance from the dominant landlords. In this sense, the introduction of 
the system in Kanara was the same as the case in Baramahar, which stressed continuity rather than disjunction from the existing form of land tenure in the region (see Ota 1994, p. 232). Munro presented the land and tax system of the Vijayanagara period as an ideal type, and considered the ryotwari system as succeeding this ideal type. By doing so, he insisted on the historical continuity of the old and new systems, and called for a return to the ideal state before the period of despotism of Hyder and Tipu.

As Stein points out, Munro's policy and use of history may have been a reconstruction or invention to legitimise the colonial plan and avoid resistance from the landlord class, which was also the armed forces in Kanara at the time. However, we could also say that Munro's theory in the 1800 report was an 'invention of history' to initiate land and tax policies suited to the land use/holding specific to Kanara, and to convince the Madras government not to import the zamindari system of Bengal.

\section{Characteristics of land and tax policy of colonial Kanara}

So far we have seen that land and tax system of colonial Kanara matched the existing land tenure system rather than introducing new changes. Hence the rights of existing landholders were maintained. However, it is doubtful whether it can be called 'private, individual ... proprietorship' (Stein 1989, p. 67; see also Stein 1983, pp. 44-45) as Arbuthnot states in accordance with Munro's theory.

Munro repeatedly stresses the existence of small-scale private land ownership in Kanara. This may have been an attempt on his part to promote the application of the ryotwari system, and to persuade the Madras government that its request to introduce a land tax system based on the zamindari system would be unsuitable for Kanara. As I will mention later, in South Kanara, it was actually the matrilineal joint families (kuțuma) of village landlords or guttus that owned several plots as family land. Hence it is not appropriate to consider this in terms of private land ownership by individuals. A guttu family's rights to land and its products were inseparable from its ritual duties and rights in village society.

Many of the powerful landlords in colonial Kanara were Baṇta (Madhava 1984; Stein 1989, pp. 71-72). Munro's land policy took into consideration the rights of Banța, who constituted the armed forces at the time, to avoid their resistance. Hence their rights to land were not so impaired by the introduction of new policies. In fact, as Damle points out, it is possible that the village landlords became the pațadarrs under the new land policy and strengthened their status and authority in village society (Damle 1991).

What is interesting in relation to this point is the role of patteru (Patel). As Ota points out in the case of Baramahar, patterus were appointed from upper-class farmers to collect land tax from each village and mediate conflicts in the villages, along with the introduction of the ryotwari system (Ota 1994, pp. 230-231). ${ }^{22}$ In South Kanara, this contributed to strengthening 
the authority of village landlord families. In the case of Perar, the eldest man of the Mundabețtu guttu was appointed as the patterụ from generation to generation, and this was the second most important post after that of the gadipatinārụ. This is significant in relation to büta rituals. The gadipatinārụ's role in būta rituals and the patterựs role in village administration were complementary in leading and constructing the ritual, political, and legal system on which local society was based. These roles were monopolised by the family of the most powerful guttu.

The selection of pattadārs and appointment of patterụ in colonial South Kanara re-established the guttus' land rights and administrative/judicial roles in local society, which had hitherto been inseparable from their roles in büta rituals, as 'secular rights' cut off from the ritual context. At the same time, these rights were re-defined as subordinate to the authority of the colonial government. That is to say, the colonial government made a selection from the various rights and roles of the guttus given and acknowledged by deities, and attached new politico-judicial rights and roles to those that they thought belonged to the secular sphere. At this stage, it seems that guttu families, who had been exercising rights related to būta rituals, monopolised secular authority established by colonialism. As a result, the powerful guttu families came to take on both the rights and roles based on büta rituals and customary law, and the politico-judicial roles ascribed by the colonial government.

In this way, the colonial land and tax system strengthened rather than weakened the rights and status of landlords by institutionalising the existing land tenure system. As I will mention later, the monopoly over land by Banța landlords became one of the targets of land reform in South Kanara after independence. In the next section, I will look at land holding and use, and the registration of pațtadārs in early twentieth-century South Kanara focusing on cases in Mudu Perar.

\section{Paṭtadār and land tenure in early twentieth-century Perar}

\section{Land policy in South Kanara after the period of Munro}

In this section, I will examine land tenure and patṭadārs in early twentiethcentury Mudu Perar based on administrative records published in 1904. Before doing so, let me summarise the history of land tenure in South Kanara after the introduction of a new system by Munro, based on the writings of Sturrock (1894), Abhishankar (1973), and Bhat (1998).

The Revenue Board considered Munro's land and tax policies to be sufficient, and tax collection policy in line with Munro's plan was put into practice for approximately ten years. However, in the report about taxation from 1810 to 1812 , it was suggested that the landholders were being excessively affected by land tax assessment. In response to this, the Revenue Board demanded submission of a report from Alexander Read, the collector at that time. In a report submitted in January 1814, Read called for attention to be 
paid on the maximum limit of tax suggested by Munro. Read also suggested reducing the assessment from 4\% to 7\% according to region (Sturrock 1894, pp. 101-102; Abhishankar 1973, p. 429).

The report by Read and his successor, Thomas Harris, made the Board see that the actual tax rate was a heavy burden on landholders. The Board 'were of opinion that the best standard of demand would be the average collections realised from each estate since the province had been under the British Government' (Sturrock 1894, p. 102). This assessment was carried out in the year Fasli 1229 (1819-1820) (Sturrock 1894, pp. 102-103; Abhishankar 1973, pp. 429-430; Maclean 1989 [1885], p. 63; Bhat 1998, pp. 107-108). ${ }^{23}$

In 1834, the collector, H. Viveash, suggested the introduction of a comprehensive assessment of uniform and permanent land tax. Viveash also classified various holdings (warg) according to how they were taxed, including bharti, holdings where it was possible to pay all the tax levied by the fixed assessment, and kambharti, holdings where it was not possible to pay all the tax levied by the fixed assessment. The method of tax collection he proposed was put into practice by local administrators, but it was not ultimately approved by the Revenue Board (Sturrock 1894, pp. 107-108; Bhat 1998, pp. 114-115). The failure of Viveash's revision of assessment was considered to be a problem of the tax collection system in Kanara where there was no accurate registration. The Revenue Board then began to search for a fairer method of assessment. In 1848, T. L. Blane submitted a detailed report on the land use and tax collection in Kanara, and debates over revision of survey and assessment continued till the 1880s (Sturrock 1894, pp. 107-114).

By the end of 1859, a major administrative change took place dividing Kanara into North Kanara district and South Kanara district. In 1862, North Kanara district was annexed to the Bombay Presidency, and only South Kanara district came under the Madras Presidency. Survey for taxation was conducted in South Kanara district from 1889 to 1896 . The survey made it clear that many warg were no longer units of land holding. ${ }^{24}$ Warg included several types of wetland, dryland, such as bayilu/bailụ, majalụ, and bettu, as well as land called bagayat suitable for cultivation of areca nuts and coconuts. Supplementary survey was conducted to classify land in further detail, and survey classifying the soil of bagayat continued until 1903. Reassessment mainly restricted to the rise in prices of standard crops was conducted from 1934 to 1935 (Abhishankar 1973, pp. 431-436).

\section{Land tenure and pațtadārlpațtadārti in early twentieth-century Mudu Perar}

What were the conditions of land tenure in colonial Mudu Perar? How did landlords, such as the Mundabetțu guttu, respond to the introduction of land tax assessment and registration of patțadārs? I discuss this in this section by referring mainly to Survey and Settlement Register, Mudu Perar Village, No. 53 (Couchman 1904, referred to below as SSRM). ${ }^{25}$ 
As I mentioned in Chapter 2, Mudu Perar and Padu Perar were originally one village which was administratively divided in 1904. According to SSRM, land tax assessment was introduced to Mudu Perar in the year Fasli 1312 (1902-1903). SSRM of Mudu Perar I refer to in this section was recorded by M. E. Couchman, the Special Settlement Officer, and published by the Revenue Settlement Office of Mangalore.

According to SSRM, the area of Mudu Perar was 2,208 acres 1 cent. Table 9.1 shows holdings of pațtadārs in Mudu Perar in year Fasli 1312. According to the table, 104 single pațtadārs and 10 joint pațtadārs, that is a total of 114 patṭadārs, were registered in Mudu Perar. The total area owned by these patțadārs was 936 acres 35 cents. The average area owned by a patțadār was 8 acres 21 cents, and the total amount of land tax was 3,320 rupees 10 annas.

If we look at the number of patțadārs in terms of payment, the largest group of 44 cases was within 'Rupee 1 to Rupees 10'. The average holding of pattadārs in this category is 2 acres 92 cents. The next largest group of 26 cases was those that came under 'Rupees 10-30' with the average holding of 6 acres 90 cents. There were nine patțadārs whose payment exceeded 100 rupees. Within this category, only two cases were included in the category of 'Rupees 250-500' with the average holding of 93 acres 42 cents.

From the above, we see that in Mudu Perar in year Fasli 1312, most registered pațtadārs were comparatively small-scale 'ryots' with approximately 3-7 acres of land. However, if we count joint patțadārs, and religious institutions, such as temples, mutts, churches, mosques as 'one pațtadār',

Table 9.1 Land holding and land tax assessment of paț̣adār in Mudu Perar (Fasli 1312)

\begin{tabular}{|c|c|c|c|c|c|c|c|c|c|}
\hline \multirow[t]{3}{*}{ Pațtadār paying } & \multicolumn{3}{|c|}{ Number } & \multicolumn{4}{|l|}{ Area } & \multirow{2}{*}{\multicolumn{2}{|c|}{$\frac{\text { Assessment }}{\text { Total }}$}} \\
\hline & \multirow[t]{2}{*}{ Single } & \multirow[t]{2}{*}{ Joint } & \multirow[t]{2}{*}{ Total } & \multicolumn{2}{|l|}{ Total } & \multicolumn{2}{|c|}{ Average } & & \\
\hline & & & & Acres & Cents & Acres & Cents & Rupees & Annas* \\
\hline Rupee 1 or fewer & 15 & & 15 & 8 & 28 & 0 & 55 & 8 & 10 \\
\hline $\begin{array}{l}\text { Rupee } 1 \text { to } \\
\text { Rupees } 10\end{array}$ & 37 & 7 & 44 & 128 & 56 & 2 & 92 & 182 & 13 \\
\hline Rupees 10-30 & 24 & 2 & 26 & 179 & 51 & 6 & 90 & 532 & 2 \\
\hline Rupees 30-50 & 11 & 1 & 12 & 104 & 71 & 8 & 73 & 473 & 13 \\
\hline Rupees 50-100 & 8 & $\ldots$ & 8 & 128 & 29 & 16 & 4 & 574 & 8 \\
\hline Rupees $100-250$ & 7 & $\ldots$ & 7 & 200 & 16 & 28 & 59 & 900 & 6 \\
\hline Rupees 250-500 & 2 & $\ldots$ & 2 & 186 & 84 & 93 & 42 & 648 & 6 \\
\hline $\begin{array}{l}\text { Rupees } \\
\qquad 500-1,000\end{array}$ & $\ldots$ & $\ldots$ & $\ldots$ & $\ldots$ & $\ldots$ & $\ldots$ & $\ldots$ & $\ldots$ & $\ldots$ \\
\hline $\begin{array}{l}\text { Rupees } 1,000 \\
\text { or more }\end{array}$ & $\cdots$ & $\cdots$ & $\cdots$ & $\cdots$ & $\cdots$ & $\cdots$ & $\cdots$ & $\cdots$ & $\cdots$ \\
\hline Total & 104 & 10 & 114 & 936 & 35 & 8 & 21 & 3,320 & 10 \\
\hline
\end{tabular}

Source: Based on Couchman (1904: 2) with addition of the average area by the author.

* 1 rupee $=16$ annas. 
we see that the total number of 114 patțadārs only constituted $6.4 \%$ of the total population of 1,768 Mudu Perar in 1901. It may appear from this that just $6.4 \%$ of the total population monopolised land, but the situation was not so simple.

It should be noted that apart from religious institutions, many people registered in the SSRM of 1904 were not land owners with exclusive rights to land assessed in their name. Their names were registered as representatives of families who had joint rights to the land. This was especially the case with female patțadārtis belonging to Banta matrilineal joint families. For example, as we will see later, the name of a patțadārti called 'Mundabețtu Poovu' appeared the most in SSRM. This did not mean that she ruled over or occupied many holdings. Rather, her name represented the rights of the members of her kuțuma over family land.

Table 9.2 shows the 114 patțadārs registered in SSRM by caste and type. We see that the 'single' category constituted mostly of Muslims with 37 registered as patțadārs, then of Banța with 31 registered as pațtadārs. Names of 13 Brahmans, nine Christians, and seven Konkani are registered as pațtadārs. Among the religious institutions registered as patțadārs in SSRM were Pējāvara Mutt in Udupi ${ }^{26}$ God Sri Venkatramana temple of Gurpur, and the village būta shrine in Padu Perar. The names of managers of these respective institutions were registered as the patțadārs. It is interesting that in SSRM, the village būta shrine was registered as 'God Bala Madi Temple'. This shows that büta shrines were considered to be the same as Hindu temples in administrative terms and were treated as such at the time. The Roman Catholic Church and the mosque in Mudu Perar were also registered as pațtadārs.

Table 9.2 Caste/type of pațtadārs

\begin{tabular}{llc}
\hline & Casteltype & Number \\
\hline Single & Muslim & 37 \\
& Baṇta & 31 \\
& Brahman & 13 \\
& Christian & 9 \\
& Konkani & 7 \\
& Temple * & 2 \\
& Mutt & 2 \\
& Unknown & 3 \\
& Pūjāri or Kuḍubi & 1 \\
& Mosque & 1 \\
& Kudụubi & 1 \\
Joint & Church & 1 \\
& Bañta & 4 \\
Total & Brahman and Baṇta & 1 \\
& Brahman and Muslim & 1 \\
& & 114 \\
\hline
\end{tabular}

* Includes one shrine in Perar registered as a 'temple'. 
Four groups consisting only of Baṇțas, one group of Brahman and Baṇța, and one group of Brahman and Muslim were registered as joint patțadārs. From this, we see that apart from the religious institutions mentioned above, Muslims, Banțas, Brahmans, Christians, and Konkani were the main landholders in Mudu Perar at the time. However, the number of names registered as patṭadārs, such as 37 Muslim and 31 Baṇta, did not necessarily accurately reflect the number of plots owned by each group. This was because there were many cases of several plots being registered under the name of one patțadār. Table 9.3 shows the total number of registered pațtadārs corresponding to assessed plots.

As we can see from Table 9.3, single holdings were mostly plots registered in the name of Baṇta patțadārs. The order of numbers of registration changed to Brahmans, Muslims, Christians, and Konkani. A total of 20 cases of joint patțadārs constituted of Baṇțas were registered. As we have already seen, a total of 31 Baṇta names were registered as single patṭadārs. This meant an average of about 10.9 plots per person; that is to say, one Banta was registered as the pattadār of an average of over ten plots in SSRM. In this way, in SSRM, several plots were registered under few names of persons as pațtadārs. In particular, a woman called 'Poovu' of the Mundạbetțu guttu was registered as the patțadārti of a total of 68 plots. Table 9.4 shows the total number of registered Baṇta pațtadārs by family.

As Table 9.4 shows, the most numerous of the single pattadārs were 93 belonging to the Munḍabetțu guttu, followed by 30 of the fifth guttu family,

Table 9.3 Total number of registered pațtadārs corresponding to assessed plots

\begin{tabular}{llc}
\hline & Casteltype & Number* $^{*}$ \\
\hline \multirow{2}{*}{ Single } & Baṇta & 337 \\
& Brahman & 129 \\
& Muslim & 108 \\
& Christian & 49 \\
& Konkani & 35 \\
& Mutt & 28 \\
& Pūjāri or Kuḍubi** & 15 \\
& Temple*** & 12 \\
& Unknown & 5 \\
& Church & 4 \\
& Mosque & 3 \\
Joint & Kuḍubi & 1 \\
& Bañta & 20 \\
Total & Brahman and Bantạa & 6 \\
& Brahman and Muslim & 3 \\
& & 755 \\
\hline
\end{tabular}

* Number of holdings assessed $=$ total number of registered pațtadārs.

** Unable to determine the caste from the registered surname.

*** Includes the shrine of Perar registered as a 'temple'. 
Table 9.4 Total number of registered pațțadārs belonging to Baṇța (by family)

\begin{tabular}{|c|c|c|}
\hline & Family & Total number ${ }^{*}$ \\
\hline \multirow[t]{4}{*}{ Single } & Unable to specify & 208 \\
\hline & Mundạabețțu guttu & 93 \\
\hline & Alake guttu & 30 \\
\hline & Tidyamuñdoțțu guttu & 6 \\
\hline Joint & Mundabettu guttu & 20 \\
\hline Total & & 357 \\
\hline
\end{tabular}

* Number of landholdings assessed = total number of registered pațtadārs.

Alake guttu, and 6 of the third guttu family, Tidyamundotottu guttu. Members of joint pațadārs registered under several names all belonged to the Munidabetțu guttu. We can specify the above three families among the pațtadār/patțadārti in cases where the name of the registered person and the name of the family to which she belonged are written next to each other, for example, 'Mundabettu Poovu' and 'Alake Mammu'. ${ }^{27}$

It is interesting that in the case of these guttu families, persons registered as representing each family were all women, and there were no male pațadārs prefixed with the name of the family. In the Mundabețtu guttu, there were two names of women, 'Mund̦abețtu Poovu' and 'Mundiabețtu Kunni'. Two women called 'Alake Mammu' and 'Alake Kunni' in the Alake guttu, and a woman called 'Sanna Mund̦abețtu (small Muṇ̃abețtu) Mammu' ${ }^{28}$ in the Tidyamundọtoțu guttu were registered as pațtadārtis. As I have already mentioned, Poovu was registered as the pațadārti of a total of 68 plots, and Kunni as that of 25 plots in the Mundabețtu guttu. Mammu was registered as the patțadārti of 26 plots and Kunni as that of four plots in the Alake guttu. Mammu was registered as the patțadārti of six plots in the Tidyamuniḍoțtu guttu.

These women were chosen as pațadārtis of several plots held by their respective matrilineal joint families (kuțuma Ka. kuțumba). This seems to explain why so many plots were registered under the name of one patțadārti. There were 19 women (approximately 17.6\%) among the total of 108 single pațadār/patțadārti registered in SSRM. Banța pațtadārtis were the most numerous, as there were fifteen Bantas, two Christians, one Muslim, and one unknown. Among the total number of 31 Banta pațadārs, almost half were women.

As we will see from the following chapter onwards, the registration of pațtadārti came about due to the combination of aliyasantāna kațtu, the matriliny of South Kanara, and the modern legal system. Due to the introduction of land tax assessment in the early twentieth century, local landlords including the Mundabețtu guttu were made to publically register the 'owner' of plots hitherto jointly held and managed by matrilineal joint families. The eldest woman representing the kuțuma was chosen as 
the pațtadārti following the legal interpretation and definition of matriliny constructed during and after the colonial period.

From such selection and registration of pattadārtis, we can see that not only did the existing landlords became patțadārs under the new system of land tenure, but the kinship system based on matriliny was also applied to the new system in South Kanara. As I will explain in more detail in Chapter 10, legal and administrative policies since the colonial period, such as land tax assessment, registration of pațadār/patțadārti, and modernisation of customary matriliny, fixed the category of matrilineal joint family and required the construction and substantiation of land rights of its members.

\section{Land reform after independence}

After India's independence from British rule in 1947, land policy in South Kanara entered a new phase led mainly by the state government (the state of Mysore, which later became the state of Karnataka). In this section, I will discuss the contents and consequences of land reforms in South Kanara after independence focusing on the Mysore Land Reforms Act, 1961 (Mysore Act No. 10 of 1962) and the Karnataka Land Reforms (Amendment) Act, 1973 (Karnataka Act No. 1 of 1974). I will give an outline based on previous research before discussing the details of individual cases in Chapter 11.

In this section, I will mainly deal with works by political economists on the state of Karnataka, whose common question was 'Why were land reforms unsuccessful in Karnataka?' Political economists, such as Thimmaiah and Aziz, classify the history of land reforms in Karnataka since independence into four periods, namely, 1947-1956: period from independence to reorganisation of the state; 1956-1971: period from reorganisation of the state to the period of the enactment of the Mysore Land Reforms Act; 1971-1977: period of Karnataka Land Reforms (Amendment) Act and its compulsory enforcement; and period after 1977. They examine the contents and results of the land reforms in each period, focusing on the actions of interest groups (Thimmaiah \& Aziz 1983, 1984a, 1984b). Let us take a look at the outline of the history paying special attention to South Kanara.

\section{7-1956: period from independence to reorganisation of the state}

The abolition of tax-free land (inām) was promoted in the first period mentioned by Thimmaiah and Aziz, that is, from 1947 to 1956. In the state of Mysore at the time, Vokkaliga, Lingayat, and Brahmans constituted the landlord class, and many Brahman landlords owned ināms. Many of them were absentee landlords residing in cities, and their estates were cultivated by tenants belonged to Vokkaliga and Lingayat.

The tenant class was a vote bank of the state government at the time, and non-Brahman landlords dominated the state government. The Indian National Congress introduced progressive land reforms just after 
independence, including abolition of the zamindari system. Inām holders were the targets of reform in Karnataka. The state government began to prepare the legal grounds for abolition of inām, but required the cooperation of Brahman bureaucrats to bring them into effect. It faced difficulties in executing laws due to powerful resistance by Brahman landlords.

The Legislative Assembly passed a resolution to abolish ināms in 1947, but the resolution was not made into law until 1954. The Mysore Alienated Villages (Protection of Tenants and Miscellaneous Provisions) Act was passed in 1950 in order to protect tenants from inām holders and regulate tenancy. The Mysore (Personal and Miscellaneous) Inams Abolition Act was passed in 1954, and eventually the Mysore (Religious and Charitable) Inams Abolition Act in 1955, ordering the abolishment of religious ināms.

\section{6-1971: period from reorganisation of the state to the period of the enactment of the Mysore Land Reforms Act}

Let us examine the land policies of the second period from 1956 to 1971. The state was reorganised in 1956, and a new state of Mysore was created from the old state of Mysore, state of Coorg, and the Kannada-speaking areas of the former Bombay and Madras provinces, and of the Princely State of Hyderabad (Iyer 1997, p. 179). ${ }^{29}$ If we look at the political situation of the time, Brahmans continued to be bureaucrats, and the Lingayats and Vokkaliga constituted the landlord class. But it was the poor peasants, tenants, and the landless who constituted the important voting banks for the state government. Hence the state government could not ignore demands for land reform, and the Mysore Tenancy and Agricultural Land Laws Committee was set up in 1957. The Mysore Land Reforms Bill was submitted to the state parliament in 1958, passed in 1961, and approved by the president in 1962. However, the bill required partial amendments, and it only came to be enforced as the Act. No. 14 of 1965 (Abhishankar 1973, pp. 443-445; Thimmaiah \& Aziz 1983, p. 815).

Thimmaiah and Aziz point out that pressures exerted by the landlord class, which was a powerful interest group, led to the delay in the law taking effect. Through the legal measures by the state government, the landlord class had accumulated knowledge about land reforms from the 1940s to the early 1950s and lobbied at many stages of the decision-making process. Lingayat and Vokkaliga, the traditional landlords, sent representatives of their respective groups to parliament, and the parliament was dominated by these groups until the early 1970s. As a result, the content of the land reforms reflected the views of the landlord class. First, the Mysore Land Reforms Act set the maximum holding of a household of five persons at 27 standard acres (Thimmaiah \& Aziz 1983, p. 816). ${ }^{30}$ Actually, however, different maximum holdings were fixed according to fertility of land, availability of irrigation, and so on. For example, 216 acres of dry land was determined as equivalent to 27 standard acres. There were also provisions for allowing separate acre 
holdings per one extra family member for households with more than five persons, and exemptions for widows and the handicapped. These measures led to raising the maximum holding and served the interests of landlord class.

In this way, existing landlords did their best to protect the interests of their own groups regarding provisions for maximum holdings. We should note, however, that they did not show much resistance to tenancy regulations. These were constituted mainly of regulated rents and regulated tenures. The latter was a regulation to restrict landlords from evicting tenants and reclaiming land as their own farmland. But this provision was not sufficiently effective in the Mysore Land Reforms Act, and as a result, there was a dramatic increase in the number of evicted tenants on the pretext of landlords farming their own land.

The Mysore Land Reforms Act seemed contradictory as it put severe restrictions on tenancy on the one hand, and made provisions for raising maximum holdings on the other. But in fact, it served the interests of the dominant landlord class. Loose regulations on maximum holdings allowed landlords living in countryside time and leeway to reorganise land records so that they could continue to keep their land intact. Severe tenancy regulations enabled tenants belonging to the same group as the dominant landlord class to take away land rights of absentee landlords (mainly Brahmans) living in cities. Landlords living in the countryside were able to get around this regulation by reclaiming land from tenants as self-cultivated farms. The interests of existing landlords were maintained by such legal and administrative strategies (Thimmaiah \& Aziz 1983, pp. 815-822).

\section{1-1977: period of Karnataka Land Reforms (Amendment) Act and its compulsory enforcement}

After the Indian National Congress split up in 1969, non-landlord 'Backward' minorities dominated the parliament in the Mysore state, paving the way for more radical land reforms. In 1969, the National Planning Commission submitted a guideline in which the average family was defined as a family of five, with a father, a mother, and three underage children, and limits of land holding were set between 10 acres and 18 acres of double cropping irrigated agricultural land. It also suggested that cultivation rights of tenants and sharecroppers and existing tenancies should be guaranteed. The Mysore state government (Karnataka after November 1973) began the amendment of the Mysore Land Reforms Act. A draft of a comprehensive bill was submitted in 1971, received advice from a Joint Select Committee, and the state government passed the Karnataka Land Reforms (Amendment) Act in 1973, which was approved by the president in March 1974.

Let us look at the characteristic features of the Karnataka Land Reforms (Amendment) Act. First, it was absolutely forbidden for landlords to re-occupy leased land. Leasing of land was also abolished with the exception 
of cases involving soldiers and sailors. The maximum holding was reduced to ten units. ${ }^{31}$ A land tribunal was to be established in each taluk. This law was enforced before 1977, but the impetus for land reform gradually decreased after 1978 (Thimmaiah \& Aziz 1983, pp. 822-826).

Let us be clear about the functions of the land tribunals. By the enforcement of the Land Reforms (Amendment) Act, all private holdings leased at the time of 1 March 1974 came to belong to the government. The person leasing the land from the owner had to apply to the land tribunals for ownership. The land tribunal decided whether the land in question was leased legally and hence be handed over to the government, and whether the applicant was qualified to occupy the land. If these conditions were met in the lease, the land tribunal separated the relation between the landlord and tenant, negotiated payment of compensation between the landlord and government, fixed the land price, and arranged for a certificate of occupancy between the tenant and government. To make people abide to the amendment of the maximum holding, all those who owned more than the stipulated area had to present a declaration. The declaration was submitted to the land tribunal after checking and surveying. The tribunal had the authority to determine the area of the excess land declared (Rajan 1984, pp. 139-140).

The Land Reforms (Amendment) Act seemed to be progressive at first sight, but resulted in maintaining the interests of the existing dominant landlord class. First, regarding tenant land, apart from the cases of soldiers and sailors, all benefits for widows and the handicapped were abolished, as well as rights of landlords to reoccupy tenant land. But this law did not prevent landlords from asserting rights as tenants of other land, and this worked as an advantage for tenants belonging to the dominant landlord class. Landlord class tenants were not only given the same rights as poor tenants, but were also in a better position to purchase land. Pani (1984, p. 46) points out that, strictly speaking, the Land Reforms (Amendment) Act in Karnataka did not provide land to tenants, but gave rights to buy land at fixed prices. The government bought leased land from landlords at fixed prices cheaper than the market price, and tenants bought land from the government at the same prices. Thus, tenants who had the funds to buy land were at an advantage, and those who did not have the money had to arrange for loans.

Regarding the maximum holding, we have already seen that the Land Reforms (Amendment) Act reduced the maximum to ten units from the 27 standard acres stipulated by the Mysore Land Reforms Act. This seems to be a substantial reduction, but in reality, other changes were applied that raised the maximum holding. To identify what actually happened, we need to understand the significance of the change from acre to unit. In the Mysore Land Reforms Act, one acre of first class irrigated land was set as one standard acre. In the Land Reforms (Amendment) Act, a unit constituted land classified as over eight annas and irrigated by government irrigation facilities or water tank to ensure double cropping. Land meeting this irrigation standard was categorised as Class $\mathrm{A}$, regardless of the soil type. 
This meant that land irrigated by a privately owned water source was permitted to be held at a maximum higher than land irrigated by government facilities. As a result, landholders with private irrigation facilities were given preferential treatment.

The redefinition of the family under the Land Reforms (Amendment) Act also privileged large-scale landholders. The Mysore Land Reforms Act stipulated that a family constituted of husband, wife, and dependent children and grandchildren. Meanwhile, the Land Reforms (Amendment) Act stipulated that a family constituted of husband, wife, unmarried daughters, and underage sons. An adult son was able to demand land under the maximum amount as a member of a separate family. In the case of a large extended family, where one family member farmed the land of another member, the former was able to demand land rights as the 'tenant' of the latter (Pani 1984, pp. 44-50).

In this way, the Land Reforms (Amendment) Act appeared at first sight to be highly advanced, but, in reality, it resulted in favouring the dominant landlord class who had the money. Pani, a political economist, analyses this in terms of the gap between 'ownership' and 'control' in local society in Karnataka (Pani 1984, p. 54). He points out that the Land Reforms (Amendment) Act emphasised attack on land ownership rights, and did not consider the issue of who controlled the land. Ownership and control did not necessary match in local society in Karnataka. For example, by registering the land under the names of several family members, a landlord could control several hundred acres of land without leaving any redundant land for redistribution. The incursion on ownership by the Land Reforms (Amendment) Act thus provided an 'ideal' way to maintain social control. By only confronting ownership rights without doing anything about the aspect of control, the Act had led to disadvantaging small-scale peasants and agricultural labourers while privileging the landlord class.

Pani's distinction between 'ownership' and 'control' is insightful. In particular, he makes an important point about the Land Reforms (Amendment) Act of 1974 that targeted 'ownership' of plots, when in fact the idea of ownership of plots had little meaning in the context of existing form of land tenure in local society in Karnataka. This also applied to the establishment of patțadārs by the colonial administration. The collector divided land into plots and made the person possessing the title deed of each plot the land owner who was responsible for paying land tax. But, there was no corresponding relationship between a plot and an exclusive owner, as the system of land tenure in the locality was based on family groups.

We need to consider, however, the local practices of land tenure in more detail before we discuss the division between 'ownership' and 'control'. As we will see from Chapter 10 onwards, in villages in rural South Kanara, it was the matrilineal joint family (kutuma) as a whole that had joint rights over several holdings. It was not that one landlord controlled a vast amount of land registered under names of family members, as Pani assumes. The sub-group 
of kuțuma, kabaru (Ka. kavalu), was the unit of exercising usufruct for each holding, as well as managing and distributing land and its products. Such form of land tenure makes not only the 'ownership' of each holding but also the 'rights to control' of land owned by the kuțuma unclear. As I will discuss in more detail later, joint holding of land by the kuțuma was intimately connected to matrilineal inheritance and the succession of büta rituals in the kuțuma.

\section{Transformation of land tenure in South Kanara}

I have given an overview of the transformation of the land tenure in South Kanara from the Âlupa period through the colonial period to land reforms after independence. In the wetlands of South Kanara where agriculture was predominant, land and its products were important resources for the people and income for the state treasury since the early Âlupa period. Land also connected various people and groups through donation, transfer, sale, and lease. In the Vijayanagara period, types of land and land tax were classified in detail, and land policies were developed including assessment of land tax.

The colonial introduction of the ryotwari system divided land, which had plural and layered rights, into holdings, and tried to bring about a new oneto-one relationship between each holding and its holder/tax payer. But in South Kanara, the ryotwari system was changed to suit the existing system of land tenure. Land tax assessment based on the unit of warg constituting several holdings, and system of tax collection with the warg holder being the tax payer was adopted. As a result, the existing form of land holding did not undergo great change, and the rights of landlords were maintained. After independence, South Kanara underwent two large-scale land reforms. But, in spite of measures such as the establishment of maximum limit of land holding and abolishment of leasing, the existing landlord class continued to maintain their rights through various measures that gave them leeway.

In this way, various land policies were carried out in South Kanara from the colonial period to after independence, but these did not lead to the collapse or fundamental changes in the local system of land tenure. Hence we also cannot unquestioningly presume changes or decline in büta rituals that were closely connected to land holdings of landlords, as some previous studies suggest (Rajan 1986, p. 54; Gowda 1991, p. 18).

Enforcement of land policies by governments and their transformation indeed had significant influence on land tenure in local society. However, we should consider the entanglements and reflective relationships between the traditional system and various measures carefully, rather than simply seeing the measures as external forces that led to change and dismantling of the traditional social system. Analyses I discussed in this chapter that focus mainly on politico-economic aspects tend to overlook the relationships between traditional system of land tenure, kinship organisation, and local religious rituals, as well as the dynamics between them. In the case of 
South Kanara, these relationships would be those between land tenure and family organisation based on matriliny, and būta rituals. In Chapter 10, I discuss the process of modernisation of matriliny in South Kanara since the colonial period. I also analyse the people's responses to the introduction of new legal systems focusing on the attempts to divide inheritance of land in the Muṇạabetțu guttu.

\section{Notes}

1 Patțadār literally means the holder of land deed (patta) and refers to the landholder. However, as I will mention later, patțadār (male) and patțadārti (female) among the Banța landlord class in South Kanara were not 'land owners' with exclusive rights to land, but representatives of matrilineal joint families with joint landholdings.

2 The period of beginning of Ālupa rule is unclear. References to Ālupa rulers appear in inscriptions from the sixth century (Abhishankar 1973, pp. 37-38).

3 The Keladi clan emerged in the early sixteenth century. Keḷadi Nāyakas continued to be feudatories of the Vijayanagara Empire even after the defeat of Vijayanagara forces at the Battle of Rakkasa-Tangaḍi in 1565. In 1614, Venkațappa-nāyaka I declared independence from the empire (Abhishankar 1973, p. 54; White 2015, pp. 63, 92).

4 See also Bhatt (1975) for a history of South Kanara.

5 I refer to the person who held the land and was responsible for paying land tax as the 'landholder'. I also use the term 'landholder' interchangeably with patțadār, who paid land tax after the colonial period. In South Kanara, land was jointly held by Banța matrilineal kin groups, and their representatives were registered as patțadārs. I distinguish between the 'landholder' and 'landlord (guttu)'. Guttu is the dominant class in village society and have ritual roles. (As I will show, the landlords and landholders overlap. But not all landholders are guttus.)

6 According to Vasantha Madhava, Jain landlords exercised power in administrative districts called māgane in the Vijayanagara period (Madhava 1984, p. 5). However, during the rule of Hyder Ali and Tipu Sultan, these Jains lost their position as rulers and became simply landholders.

7 There are many references to the borders of land owned by guild organisations in the inscriptions of this period. It was the duty of the managers of land donated to temples to offer prescribed amounts of crop to the temple deities, irrespective of good or bad harvest (Ramesh 1970, p. 288).

8 These titles are used today in Perar as names of būta priests and heads of landlord families.

9 Such a system can be called a 'system of entitlements' centred on the büta shrine and guttu families, and is important for understanding the nature of landlords in South Kanara. For details on system of entitlements, see Tanabe (2006).

10 Nāyaka was a title given to Chaudappa Gauda (1500-1540) of the Keladi clan by the Vijayanagara king of the time (Abhishankar 1973, p. 54).

11 Madhava points out that in this period, some of the bütas were seen as 'secondary deities' and were demoted to the status of deities subservient to sīme deities. At the same time, the form of būta rituals came to be influenced by Brahmanical rituals (Madhava 1985, pp. 21-23, 143).

12 India Office Library and Records, London, Madras Revenue Consultations, 19 September 1800, pp. 2239-2248 (quoted in Stein [1989, pp. 67-68]).

13 Kanara is a region corresponding to Uttara Kannada, Udupi, and Dakshina Kannada districts in the present state of Karnataka, and Kasaragod district in the 
present state of Kerala. Munro's term in Kanara was from July 1799 to October 1800 (Bradshaw 1894, p. 87). Kanara was divided into South and North in December 1800 , but was reunited in 1805 . It was governed as one of the collectorates in the Madras Presidency until it was divided into North Kanara district and South Kanara district in 1859 (Bhat 1998, pp. 4-8). North Kanara (except for Kundāpura taluk, which was included in South Kanara district) was annexed to Bombay Presidency in 1862, and South Kanara district was part of the Madras Presidency until it was unified with the new Mysore state in the reorganisation of states in 1956. Kasaragod taluk became part of the state of Kerala in 1956 (Abhishankar 1973, pp. 4-5). In view of this history, I refer to the place of Munro's posting as 'Kanara'.

14 Zamindar refers to the 'landlord' defined by the zamindari system, the system of land tenure and taxation introduced by Governor Cornwallis in Bengal Presidency in 1793, and practised since then throughout the British colonial period mainly in northern parts of India.

15 The word seems to have originated from the Sanskrit word varga, or Arabic word warq, meaning leaf (Sturrock 1894, p. 118; Baden-Powell 1990 [1892], p. 147).

16 On the other hand, according to Damle, warg showed the revenue account of each landholder, and this often included land of unknown size scattered in different villages and regions (Damle 1991, p. 158, note 15). Hence Damle points out that it is not appropriate to refer to warg as 'estate'. I will refer to warg as holding. For details regarding warg, see also Bhat (1998, p. 85).

17 See Maclean (1877, pp. 99-101, 114-115) and Sturrock (1894, p. 118). For details on surveys and assessments under the ryotwari system, see Baden-Powell (1907, pp. 199-206).

18 In the Mundabetțu guttu, the eldest woman of the matrilineal joint family (kutuma) was registered as the patțadārti.

19 'Memorandum Relative to Revenue Servants: Extracts of a Letter from A. Read [then sub-collector in the CD under Munro] to Another Junior Colleague, James Cochrane'. IOL, MC, F/151/10, f.95 (quoted by Stein [1989, p. 66]).

20 Bhaṇ̂āa-sthaḷa more accurately refers not to 'state land', but land which is not tax-free.

21 Against Stein's view, Chitnis (1974) points out the importance of the survey carried out by Śivappa-nāyaka in the seventeenth century.

22 See Maclean (1987 [1885], p. 154; 1989 [1885], p. 64).

23 In 1831, peasants dissatisfied with heavy taxes broke out in a 'no tax campaign' in Kanara (Sturrock 1894, pp. 104-105; Abhishankar 1973, p. 68; Rao 1991; Bhat 1998, pp. 112-113).

24 Mudu Perar and Padu Perar were also surveyed in this period. The maps kept today in public offices, such as the Deputy Commissioner's office of Dakshina Kannada and the panchayat office of Padu Perar, as maps of these two villages are based on the lithograph originals marking land zones in 1893.

25 This document is basically a closed document kept in the archives of the Deputy Commissioner's office.

26 Pejjāvara Mutt was registered twice as 'Rama Vittla Matt of Pejawar' under registration numbers 37 and 38. The name of a Brahman mūla gēni is registered under number 38 .

27 In SSRM, there are cases where the sex of the registered person is written after the name of the pațadārti, such as 'Mundọabetțu Poovu (female)'.

28 'Sanna Munḍabețtu' means the same as Tidyamundoțțu, namely, the third guttu family.

29 The state of Mysore was renamed the state of Karnataka on 1 November 1973 (Kamath 1982, p. 388). In 1997, South Kanara district (Dakshina Kannada) was divided into present-day Udupi and Dakshina Kannada districts. 
30 According to the Mysore Land Reforms Act, one acre of first-class irrigated land was stipulated as the standard acre (Pani 1984, p. 48).

31 According to Thimmaiah and Aziz, the 'land ceilings' were cut down to 10 'standard acres' (Thimmaiah \& Aziz 1983, p. 823), but I think they have mistaken it for 10 'units'. In the Land Reforms (Amendment) Act, 'a unit was defined as land with a soil classification of above 8 annas and "having facilities for assured irrigation from such Government Canals and Government Tanks as are notified by the State Government to be capable of supplying water for growing two crops of paddy in a year"" (Pani 1984, pp. 48-49; emphasis added by Pani). 


\section{Modern law, customary law, and the reflexive imagination}

As seen in the previous chapter, since the colonial period, various land policies such as the ryotwari system and land reforms have been introduced in South Kanara. Some of the main targets of these policies have been the Banta landlords, whose land tenure and inheritance are based on the matrilineal system called the aliyasantāna katțu. Since the end of the nineteenth century, the colonial judiciary recognised the aliyasantāna kattụ, which had long regulated people's practices concerning legal issues such as marriage and inheritance, and came to reconstruct this system as modern law.

How, then, has the aliyasantāna katțu been reinterpreted by the modern judiciary? How has its reinterpretation and redefinition influenced matriliny in South Kanara? How is the modern system different from the customary one, and how have the local people dealt with these differences? To answer these questions, in this chapter I will investigate the modern judicature's evolving interpretation and (re)construction of matriliny in colonial and postcolonial South Kanara and examine local practices of matriliny, focusing on their relation to būta worship. As we will see later, people have sustained and revitalised their own meaning of the aliyasantāna kattụ through various practices as they have tried to cope with new legislation on matriliny. By analysing legal discourse and popular practices, I will bring into view the reflexive imaginations of the modern judicature and of the local people, which create and recreate the reality of matriliny in South Kanara.

\section{The encounter between the aḷiyasantāna kaț̣̣ and modern law}

The only distinctive custom of the Tulu people ... is the Aliya Santana rule of inheritance, which ... means that the property of a family is vested in the female line and descends from mother to daughter; but as titles and dignities are vested in the males, and the management of the property is also usually exercised by a brother, the line of descent is ordinarily taken to be from the deceased holder to his sister's son ... Division of property cannot be enforced, and is in fact forbidden, but temporary arrangements for separate management are often made 
for convenience, and by lapse of time become practically permanent divisions in many cases.

(Sturrock 1894, pp. 140-141)

J. Sturrock was a collector in the district of South Kanara in the Madras Presidency, and his description of the matrilineal system, called the aliyasantāna kațtụ, shows its essence as understood by the British colonial officers of the time. It was understood both as a local 'custom' and as the system governing the inheritance of family property. This British understanding of the aliyasantāna kattụ was not entirely wrong, but was very limited. Despite their limitations, such interpretations of the aliyasantāna kațụ prevailed in the law courts of South Kanara from the end of the nineteenth century until the middle of the twentieth century. Moreover, through a complex interaction of modern legal thought, the principle of stare decisis, and the discourse/practice of both the judges and the local people, the aliyasantāna kattụ gradually transformed into a new system: Aliyasantana Law.

Below I investigate the aliyasantāna kattụ with a focus on the issue of the (in)divisibility of family property, which was one of the key issues during the process of its modernisation and modification. Regarding the local term 'matrilineal joint family', I use the Kannaḍa term 'kuṭumba' when I refer to official governmental practice or codification, while I use the corresponding Tulu term 'kuṭuma' when I refer to local practice. While kuțumba, which has been used in legal discourse, emphasises the descendance and economic functions of the matrilineal joint family, kutuma generally indicates the basic unit of kin who perform rituals together (see Upadhyaya 1988-1997, p. 819). As we will see in this chapter, the kuțuma under customary aliyasantāna kaț̣u is not only an economic unit but also a ritual community; it is kin relations as well as everyday life-space. Moreover, it is the node of the transactional network linking people, deities, land, and nature.

\section{The Aliyasantana Law in colonial South Kanara}

Bhat, who has investigated the various court cases concerning matriliny in both South Kanara and Kerala, argues that the aliyasantāna kattụ was transformed into and established as modern personal law when the British system of the judiciary and ownership of property came to be established in India $(2004$, p. 5). The process of the transformation of the aliyasantāna kattụ from the mid-nineteenth century to the mid-twentieth century was marked by the following significant developments: (1) the codification of the aliyasantāna kattụ and the creation of the modern form of the Aliyasantana system in the British Indian courts, (2) the enactment of the Madras Aliyasantana Act, 1949 (Act No. 9 of 1949), (3) the enactment of the Hindu Succession Act, 1956 (Act No. 30 of 1956), and (4) the enactment of the Madras Aliyasantana (Mysore Amendment) Act, 1961 (Act No. 1 of 1962). 
Beginning, then, with the first phase, we should investigate the codification process of the aliyasantāna katțu by the British judges in colonial South Kanara. From the middle of the nineteenth century to the beginning of the twentieth century, British judges relied on a pamphlet known as 'Bhuthala Pandya's Kattu Kattale' as the primary source and authority on customary aliiyasantāna kațun. The pamphlet contains the story of Bhuthala Pandya as well as the 14 kattutu and 16 kattale (commandments) relating to the management of matrilineal families. For example, it expounded on the management of family property and the perpetuation of lineage through adoption.

The origins of the aliyasantāna kattun narrated in the pamphlet are rather mystical. According to the pamphlet, the aliiyasantāna katțu was first introduced around the year $77 \mathrm{CE}$ by a despotic prince called Bhuthala Pandya, the maternal nephew of a king called Deva Pandya, in order to supersede the makkala santāna (inheritance from father to son), which was then the prevailing system in South Kanara. It is said that when Deva Pandya wanted to launch his newly constructed ships, a būta king called Kundodara demanded a human sacrifice. The king asked his wife's permission to offer one of their seven sons, but she refused; his sister Satyavati then offered up her son Jaya Pandya (later renamed Bhuthala Pandya). The būta saw a sign of future greatness in the child and permitted the ships to sail without the sacrifice. Later, Kundodara demanded that the king bestow the wealth of the kingdom on the same child, his sister's son, Bhuthala Pandya. As the newly enthroned king, Bhuthala Pandya ruled that inheritance in his kingdom must be passed from maternal uncle to nephew, and thus the aliyasantāna kattu was established in the first year of the Shalivahana Era, about $77 \mathrm{CE}$ (Rao 1898, pp. 7-8; Bhat 2004, pp. 6-7).

The pamphlet first attracted the notice of the courts in 1843, forming the basis of the decision in Appeal Suit (A.S.) 82 of 1843. After this decision, Bhuthala Pandya's kațtu was frequently referred to by the local courts, and in the early decisions of the High Court it was regarded as conclusive upon the subject. In Munda Chetty v. Thimmaju Hengsu (1863), which considered the question of the divisibility of aliyasantāna family property, the decision relied entirely upon Bhuthala Pandya's katțu as 'the work of authority' (Rao 1898, p. 14).

Through this ruling, the right to the compulsory partition of aliyasantāna family property was repudiated. This was upheld until the enactment of the Madras Aliyasantana Act of 1949, even though the pamphlet had gradually come to be considered unreliable as a source of customary aliyasantāna kațtu (Rao 1898, pp. 14-15, 104-105; Bhat 2004, pp. 7-9). ${ }^{1}$

In the mid-nineteenth century, British judges began to codify the aliyasantāna kattụ, first by referring to Bhuthala Pandya's katțu as the 'code', and then by reviewing court precedents. In this process, stare decisis in the courts was determinative; in other words, precedents themselves constituted the law, influencing subsequent decisions as well as people's practice. Through this reflexive interrelation between the law and practice, customary aliyasantāna 
kațu was transformed into the Aliyasantana Law. Simultaneously, in the legal discourse, the local families following customary aliyasantāna kattụ were reconstituted as legal entities, namely, the Aliyasantana families. In this newly formed and authorised Aliyasantana Law, the following features were distinctive: (1) the tracing of kinship in the female line and (2) the prohibition of the compulsory division of family property (Rao 1898, p. 4).

Among these features, the second seems to be the more problematic, as it engendered many disputes. The rule was inseparable from the ideal form of the Aliyasantana family as imagined by the colonial judges, namely, that 'the family presents a type of a joint family system, pure and simple, in its most archaic form' (Rao 1898, p. 78).

In the colonial courts, the unity of the Aliyasantana family and of its joint property was pre-eminently valued and persistently declared. At the same time, the rights of individual family members to the family property were limited. One judge stated, 'The preservation of the unity of the family is the only effectual mode of securing to the members, severally a full share of the beneficent enjoyment of the joint estate' (Rao 1898, p. 6). ${ }^{2}$

Additionally, the Aliyasantana family was regarded as a unit controlled by the most senior male or female member, called yajamānalyajamanni (in the masculine and feminine, respectively). ${ }^{3}$ The yajamāna/yajamāni was defined by the judges as the head of the Aliyasantana family, and he or she had the right and duty to manage the family members and their joint property. It was regarded that their duty was primarily to protect the interests of the entire family; hence, the yajamāna/yajamāni was unable to make alienations of the immoveable property without the assent of the other family members (see Rao 1898, pp. 61-65).

The judges' privileging of the unity of the Aliyasantana family and of its joint property then directed their decisions concerning the status of women in the Aliyasantana family. According to Rao (1898, pp. 48-49), the perpetuation of lineage in the female line and the devolution of property to the descendants of these women gave rise to the idea that women alone could be the sole proprietors and that men have no more than the bare right of maintenance from the family property. Thus, at least until the end of the 1880 s, British judges tended to give priority to women with regard to yajamānaship and rights to family property. For example, in 1863, Justices Frere and Holloway declared that among the Aliyasantana families in their district, 'females alone are recognised as the proprietors of the family estate' and 'all rights to property are derived from females' (Rao 1898, p. 58). Due to the influence of this view, it was persistently maintained in the courts that the yajamāni was ordinarily the most senior of the female members. This, however, does not mean that any woman could be privileged with proprietorship; rather, the status of a woman was upheld only when she was approved as the representative of an Aliyasantana family. Thus, while the law secured the property rights of senior women representatives of Aliyasantana families, it restricted the rights of 'sterile' women. ${ }^{4}$ 
Through their reinterpretation of precedents, the colonial judges codified the aliyasantāna kattụ and transformed it into modern personal law. In the process, women were primarily regarded as the channel of succession as well as the proprietors of the family property, though later the family property was considered to be vested instead in the whole family. It was precisely this united Aliyasantana family as legal entity that was created by the legal discourse in colonial South Kanara and that continued to influence law in the postcolonial era. The Madras Aliyasantana Act, 1949, inherited much from the idea of the Aliyasantana system created in the colonial period.

\section{Translating the 'custom'}

\section{The kutumba in the Madras Aliyasantana Act}

The Madras Aliyasantana Act was first published in the Fort St. George Gazette on 26 April 1949. In this Act, the word 'aliyasantāna' was newly defined, and some important terms concerning the Aliyasantana family were formally renamed in the Kannada language.

According to Definitions 3 of the Act, (a) 'aliyasantāna' denotes the system of inheritance in which descent is traced in the female line, but does not include the system of inheritance known as the marumakkattayyam in Malabar, ${ }^{5}$ (b) i) 'kavalu', used in relation to a woman, means the group of persons consisting of the woman herself, her children, and all her descendants in the female line; (ii) 'kavalu', used in relation to a man, refers to the kavalu of the mother of that man; (c) 'kutumba' means the group of persons forming a joint family with a community of property governed by the Aliyasantana Law of inheritance; (d) 'nissamtati kavalu' denotes a kavalu that is not a saṃtati kavalu; (e) 'saṃtati kavalu' means a kavalu of which at least one member is a woman who has not yet passed the age of 50 years; (f) 'yajamāna' means the oldest member, man or woman, of a kutumba or kavalu, in whom the right to manage its properties vest, or any other member or members in whom such right is vested by family custom, contract, decree of Court or otherwise (Bhat 2004, p. 25).

Of the terms that were redefined, kavalu and kuțumba are the most important to this investigation. Kavalu originally meant 'branch' in Kannada, but in the context of the Madras Aliyasantana Act, it is defined as a sub-division of the kuțumba. On the other hand, kuțumba, which was referred to as the Aliyasantana family by the colonial judges, was defined primarily as a 'community of property'. No member should request his/her share of the property of a kuțumba by compulsory division. The kuțumba, therefore, was defined in the Madras Aliyasantana Act as a matrilineal descent group whose members have common rights to the joint property. This definition corresponded to the notion of matriliny, which had formed in the nineteenth century (Bhat 2004, p. 32). Succeeding the definition and interpretation of local practice by the colonial judicature, the Madras Aliya Santana Act was designed to remould matriliny in South Kanara. 


\section{From ritual community to community of property}

In conformity with the fact that the kutumba was defined as a community of property, the Madras Aliyasantana Act assigned bookkeeping duties for each kuṭumba to the yajamāna/yajamāni (Bhat 2004, pp. 65, 71). Indeed, in the Act, the kuțumba was primarily defined as an economic unit and the yajamāna/yajamāni was regarded as the manager or trustee of its property. Here, the economic function of the original kutuma was highlighted, but was at the same time separated from its other functions. In the customary aliyasantāna kațtụ, meanwhile, the head of the kuțuma has had management responsibilities for not only family property but also būta rituals. Next, I will briefly overview the relationship between the kuțuma and būta worship under the customary aliyasantāna katțụ.

In a kuțuma, both the family property and būta shrine are inherited in the female line. Among the deities worshipped in the kuṭuma, the kuțumada daiva (family büta) closely related to the house and land of the matrilineal family is the one who grants the kutuma permission to use the land; at the same time, the prosperity and reproduction of the kutuma are ensured through the rituals for the būtas (see Claus 1991, p. 163). Part of resources and products of the land are given back to these deities as offerings and then distributed among the family members as prasāda.

The management of the property and resources of the kutuma is, therefore, not limited to the economic realm, but must be provided in relation to the būtas, who determine the continuation and prosperity of the kuțuma. In this sense, the property and resources maintained by the kutuma are not indivisible family property (Bhat 2004, p. 91) over which the kutuma has exclusive proprietorship, but rather they constitute a substance-code or divisible person that circulates between people, deities, and nature (see Chapter 6). Moreover, as a household inseparably related to its surroundings, and as involved in the flow of substance-codes generated through everyday activities such as marriage, reproduction, nurture, and care, the kuțuma itself has been an important constituent of the transactional network (see Moore 1985; Fuller \& Moore 1986).

Now it is clear why both the būta ritual and the property of the kuțuma are supposed to be maintained and inherited in the female line. Since it is only the būta ritual that ensures the continuation and prosperity of the kuțuma, from the mythological past to the future, both must be passed down through the women who link the generations. The kutuma, therefore, should be first understood as a community of ritual, rather than as a community of property. ${ }^{6}$ Despite this close relationship between the kutuma and būta worship, the religious function of the original kuțuma was disregarded in the Madras Aliyasantana Act, and it was redefined as an economic unit: the kutumba. The head of the kutumba was likewise defined as only the manager of the joint property, while his/her religious role was excluded from the legal definition. 


\section{The property of the kutumba and its partition by kavalu}

The definitions of terms such as kuțumba, kavalu, and yajamāna in the Madras Aliyasantana Act were mostly in conformity with the concepts of the Aliyasantana system formed in the colonial period. On the other hand, the Act was epochal in that it gave the kavalus the right to claim a partition of the family property.

While providing for the partition of family property, the Act made two broad divisions: (1) one category for partition claims in families who had remained undivided for four generations or more, and (2) another category for those families who had not. Under the first category, the mode of property division was three-quarters per capita among all the members of the kutumba then living, and one-quarter per stirpes among the kavalus. Regarding the second category, the mode of division was half per capita among all the members of the kutumba, and half per stirpes among the kavalus. ${ }^{7}$

Another key feature of the Act was its distinction between samtati kavalu (which refers to a kavalu that contains at least one female member who is not yet 50 years old) and nissamtati kavalu (which refers to a kavalu that has no female member under the age of 50 years). ${ }^{8}$ The relevant provision of the Act stated that if the kuțumba had even one saṃtati kavalu, any nissamtati kavalu in the kutumba would have only a life interest in the properties allotted to it. Upon the death of the last member of the last nissamtati kavalu, the life interest of that kavalu would then devolve upon the kuțumba (Bhat 2004, pp. 117-120).

This classification of saṃtati and nissaṃtati kavalu actually meant a distinction between kavalus that still had a possibility of maintaining the matrilineal line and those which did not. A nissamtati kavalu was regarded as 'sterile', and such a kavalu could not devise the properties allotted to it to the next generation, because it had no matrilineal descendants. This fact shows that in the Madras Aliyasantana Act, even though the partition of family property by kavalu was approved, the property itself was still regarded as joint property that should be maintained within the matrilineal descent group. This new legislation concerning the partition of the family property presented challenges for the local guttus. Before investigating how the guttus tried to cope with these challenges, I will consider in the next section the changes in the modern judiciary's recognition of the divisibility of the kutumba and its property.

\section{From dividual person to individual property?}

The Madras Aliyasantana (Mysore Amendment) Act of 1961 revised the 1949 Act. In this Amendment Act, which was introduced as Act No. 1 of 1962 in the Mysore Legislature, it was declared that the living members of the kutumba had the right to claim a partition of the family property. 
Also, the per capita mode of division was extended to include voluntary partition among the living members of a kutumba. Thus, the Amendment Act approved the right of individual members to claim and use an allotment of family property during their lifetimes. ${ }^{9}$ Additionally, the allotments of each member were regarded as separate properties, which could be devised to his/her descendants.

Since the nineteenth century, then, customary aliyasantāna kattu has been transformed into modern law by the colonial as well as the postcolonial judiciary. An analysis of this process reveals that the views of the modern judiciary regarding the Aliyasantana system have gradually shifted from those that strongly insisted on the indivisibility of the kutumba and its joint property to those that affirmed the right, first of the kavalu and then of individuals, to make claims for the partition of family property. This shift may be interpreted as indicating an ideological change in the legal discourse in South Kanara from the nineteenth to the twentieth century, namely, the change from the construction and cementing of the Aliyasantana system by the colonial judiciary to its gradual liberalisation by the postcolonial judiciary.

On this point, the bench of the Madras High Court stated in 1955:

Before the establishment of Courts by the British Indian Government, the customary law in this country contained in itself the mechanism of change reflecting the principle of growth. Changing situations led to changes in customs, and variations in the law and practice were effected to keep pace with such changes. It was only the establishment of Courts by the British Government with the principle of stare decisis that arrested this process of natural growth. ${ }^{10}$

The bench also stated that such a solidification of the law had become inconvenient to the community, 'when individualism was expressing itself and replacing the earlier concept of group-life and family entity'. ${ }^{11}$

As seen in this chapter, the establishment of the aliyasantāna kațtu as modern law also entailed defining the ideal form of matriliny and joint families in South Kanara, such as aliyasantāna, kuțumba, and kavalu. At the same time, people's practices came to be oriented and regulated by modern law. As the bench of the Madras High Court pointed out, this may be interpreted as a process of the reconstruction and solidification of the aliyasantāna kattụ and the matrilineal joint family by modern law (cf. Jeffrey 2004/2005). Moreover, if we consider the discussion in Chapter 6, the transition of the aliyasantāna kațtụ might be understood this way: the kuṭuma-originally part of the dividual persons linking people, deities, land, and nature-was redefined by modern law, first as an indivisible community of property or kuțumba, and subsequently as separated from its property, when individuals were authorised as the proprietors of the divided family property and the kutumba as a whole gradually dissolved. 
It risks oversimplification, however, to take the matrilineal joint family as only a community of property and to conclude that this community was unilaterally constructed by colonial legal discourse and then deconstructed by the postcolonial judicature. This attitude of evaluating the kutumba merely by its economic function, an attitude shared by the colonial and postcolonial judicature, tends to disregard another significant aspect, which generates the actuality and communality of the matrilineal joint family: the (spi)ritual aspect.

Unlike the kutumba defined by legal discourse as an indivisible community of property, the kuțuma under the customary aliyasantāna kattụ had, and still has, multiple facets: it is an economic as well as a ritual community; it is kin relations as well as life-space; and it is a component of the transactional network linking people, deities, land, and nature. Needless to say, this multiplicity of the kutuma has not been unilaterally constructed by modern law, and hence it cannot be easily dissolved by transitions in law. It is therefore necessary to consider the difference and reflexive relationship between the kuțumba, whose unity can indeed be shaken by legal change, and the kuțuma, which can be maintained as a multiple community despite such change.

The above investigation clarifies that when we consider the transformation of the aliyasantāna kațtụ in South Kanara, it is not appropriate to assume a unilateral transformation of customary law into modern law. Neither is it appropriate to assume that the process of modernisation after independence has somehow rectified the 'biased' colonial-period views that led the colonial judicature to create the Aliyasantana Law and the ideal family, the kuțumba, as an 'archaic form of matriliny' (Rao 1898).

Throughout the colonial and postcolonial period, the aliyasantāna kattụ has been reconstructed as modern law, and its definition and interpretation by the modern judicature has oriented people's practices. The legal discourse, however, has focused on and regulated only a limited part of the vast phenomena related to the aliyasantāna katțu. While coping with new legislation, people have maintained various practices that have never been regulated fully by modern law. The aliyasantāna kațtu and kuțuma for the local people have certainly been partially reconstructed by modern law, yet they have never been identical to those defined by modern law. With this discrepancy and ambivalence, people have experienced the transitions in law and have reflexively (re)created the aliyasantāna katțu and kuțuma for themselves. Next, I will investigate people's practices concerning the transition in the aliyasantāna kațtụ, focusing on the Munịabeț̣u guttu in Perar from the early- to mid-twentieth century.

\section{Under the enactment and amendment of modern law}

Since the nineteenth century, customary aliiyasantāna kațtụ in South Kanara has been reconstituted as modern law, and the modern judiciary has defined important terms concerning the matrilineal family. In the succession of the 
enactment and amendment of laws, how have the local people practised the aliyasantāna kațtụ, and how have their practices transformed? To answer these questions, focusing on the Mundabatțu guttu, I will first investigate people's understanding of the customary aliyasantāna katțu, which has been formed and practised historically. The guttu's interpretation and practice of the aliyasantāna kațtu mostly correspond to the modern Aliyasantana Law, yet they remain partially distinct, most remarkably in that the aliyasantāna kațtu and būta worship are inseparable in their practice. I will then examine the partition plan of the Mundabețu guttu's family land, which was designed in the 1950s. Through these investigations, I will show how the people have understood and practised their kațụ, while also coping with modern law.

\section{Kuṭuma, pergade, and büta worship}

I will first elucidate the customary aliyasantāna katțu practised among the guttus, based on interviews with the core members of the Mundabetțu guttu.

The matrilineal joint family is called kutuma. Descent is based on the female line, and a kuțuma is composed of several sub-groups called kabarụ. ${ }^{12}$ In the Mundabețtu guttu, there are three major kabarụs in the kuțuma, and these are regarded as the original kabarụs descended from three female ancestors. The ordinary kabarus, which each consists of a mother and her matrilineal descendants, are generally called onjappa jōkulu ('one mother's children') or ula kabaru ('sub-kabarụ'). Hereafter, I refer to the three original kabarụs as the 'major kabarụs' and the ordinary kabarụs simply as 'kabarụs'.

In the Mundabețu guttu, while only female members can act as the fulcrum for descent and any bifurcation of the kabarụ, in most cases a senior male member has been selected as pergade (the head of the family), who is responsible for the management of the joint property and büta worship in the kutuma. The title of the pergade is generally succeeded from mother's brother to sister's son.

Customarily, the management of family land was entrusted to the pergade, who distributed agricultural products to the other members. Therefore, the family land could be neither divided nor registered as private property. In such a situation, in the beginning of the twentieth century when the government requested the kutuma to register a representative/taxpayer of the joint property at the Revenue Board, it was the most senior female members who were selected as patțadārti (see Chapter 9). When registration started, it was necessary not only for the kuțuma but also for each kabarụ to register a representative of its joint property (land called 'land from grandfather', as discussed later). It was again the most senior female member who was selected as the representative of her kabarụ's land ownership. In addition, as we will see, in the beginning of the 1950s when the Mundabetțu guttu attempted to partition the joint property, female members were given land rights that 
could be passed down to their matrilineal descendants, while male members were given land rights only for their lifetime.

For the Mundabețtu guttu, the continuation of the kuṭuma in the female line has thus been vital: female members have been regarded as the axis of succession for both the family land and buta worship, while senior male members have taken on the role of managers of the joint property and rituals in the kuṭuma. ${ }^{13}$

\section{The land tenure of the kutuma and kabaru}

In Perar, the land held by villagers under the aliyasantāna katțu is classified into three categories: (1) family land, (2) purchased land, and (3) land acquired through land reforms. Moreover, among the guttu families, 'family land' is further classified into two subcategories: (a) traditional family land (kutumada bümi) and (b) land purchased by a member of the kuțuma (ajjererudu baidena: 'land from grandfather', hereafter, 'grandfather's land').

Among these subcategories, the traditional family land is the land that is believed to have been passed down for centuries in the female line. In a guttu family, the pergade is in charge of the management of this kind of land, while all the members of the kutuma potentially have rights to it. Unlike this traditional family land, 'grandfather's land' is land that was purchased by a male member of the kutuma in the past. Unless it has been registered in the name of the purchaser and also legally inherited by his children, this land is customarily inherited by his sisters and their matrilineal descendants. In other words, after the death of the purchaser, 'grandfather's land' becomes part of the joint property of his mother's kabarụ. Unlike traditional family land, in which all the kutuma members have potential ownership, in the case of 'grandfather's land', the range of kin who have rights to it is limited to the members of the purchaser's mother's kabarụ. Therefore, as we will see later, 'grandfather's land' has been the main subject of dispute and negotiation among the people, as they try to cope with modern law and sustain their land rights.

As already seen, the Madras Aliyasantana Act was enacted in 1949 and the Hindu Succession Act was enacted in 1956. In addition, in the 1950s the government started preparations for the legislation of the land reforms. In this situation, to retain the land rights of the entire family, the core members of the Mundabețu guttu planned to divide and register both the family land of the kuțuma and the 'grandfather's land' belonging to each kabarụ. I will next examine the partition plan of the Mundabețtu guttu.

\section{A partition plan for the kuțuma land}

The Madras Aliyasantana Act approved for the first time the partition of family property by the kabaru. We now turn to the struggle of the leaders of the Mundabețtu guttu as they tried to cope with this legislation. Needless to say, 
it proved very difficult to divide the joint property properly and to calculate the appropriate allotment to each kabarụ - and the larger the kutuma, the more problematic the task. In a judgement on one dispute over the partition of family property, Judge Govinda Menon addressed this difficulty:

At the very outset one has to marvel at the phenomenally large number of shares into which the properties are to be divided and the allotment of the various shares to the respective sharers. It is stated that this state of things is the necessary result of the working of the Madras Aliyasantana Act, 1949 ... by which the division of the properties is to be in a very complicated manner. It would require the skill of statisticians and mathematicians to work out the figures properly ... ${ }^{14}$

In the case of the Munḍabetțu guttu in Perar, it was Muttaya Shetty and some other 'elite' members of his kutuma who planned to complete this complicated task. Muttaya Shetty (1879-1952) attained the status of pergade of the Munḍabețu guttu, succeeding his mother's brother, Ishwara Shetty, in the late 1930s. A few years prior to his death, Muttaya started to plan for the partition of the family property. He drafted an elaborate plan of the partition and managed to complete a survey of the family land. However, his plan was never carried out because of disagreement among the family members about the allotment and because of Muttaya's death. His plan was written down in Kannaḍa in 1954 and copies of it have been kept carefully by some senior family members as the 'authority' on the land proprietorship of each kabarụ. Next, we turn to the details of this unrealised plan.

In 1950, the Mundabetttu guttu held a total of 79 acres of paddy fields, which could yield 600 mudi gēni of paddy ${ }^{15}$ per year, as well as a total of 83 acres of forest. Muttaya Shetty planned to divide the paddy field based not on its size but on crop yields. He planned to divide half of the 600 muḍi gēni fields by 'janasañkyepālu' (division by population) and half by 'kabarupālụ' (division by kabaru). ${ }^{16}$ This plan actually corresponds to the mode of division of family property under the second category of the Madras Aliyasantana Act: half per capita and half per stirpes.

Basically following the prescription of the Act, Muttaya Shetty made the rules of division as follows: (1) in the case of janasañkyspālụ, 300 muḍi gēni fields should be divided up according to the number of people in the kutuma (at the time, the kutuma had 231 living members). The total sum of the allotments for the members of a kabaru should be allotted to that kabarụ. Here, the base point of each kabaru should belong to the same generation as Muttaya Shetty and could be either male or female. A woman who is both the base point and representative of her kabaru would receive the total sum of the allotments for her and for the other members of her kabaru (i.e. her matrilineal descendants). If the kabarụ consists of only a man, he can enjoy his allotment only for his lifetime; after his death, the property should be handed over to one of his sisters' kabarus. (2) On the other hand, 
in the mode of kabarụpālụ, the other 300 muḍi gẹni fields should be divided equally among all 21 kabarụs of the Mundạabetțu guttu. Again, if a kabarụ consists of only a man, after his death the allotment for that kabaru should be devised to one of his sisters' kabarus.

Muttaya Shetty not only envisioned the above rules of division but even calculated the actual allotment of paddy fields and forest for each kabarụ. $\mathrm{He}$ also arranged allotments from A-schedule to W-schedule (see Table 10.1). Here, it is noteworthy that the allotments for the family shrines worshipped by two major kabarụs headed the lists of those schedules. Muttaya Shetty allotted 17 muḍi gēni for one shrine and 6 muḍi, 1 kalase, and 7 sērụ for the other; he made these allotments as the A-schedule and B-schedule.

As this suggests, Muttaya's plan itself was actually originally designed for the smooth maintenance of būta worship in the Mundabetțu guttu. That is, Muttaya Shetty and other senior members tried to secure the resources necessary for the family shrines by keeping part of the family property for those shrines. In the preface of Muttaya's written plan, this was explicitly stated:

Following the Aliyasantana Law and the decision of the kutuma, here we shall divide the land of this house. All the rituals should be maintained without any suspension. The A-schedule and the B-schedule properties should be appropriated for the expenditure on the family shrines ...

As seen in Table 10.1, his plan and calculations were very elaborate and comprehensive. He paid careful attention to each kabarụ's economic conditions as well as to the relationships among the family members in order to make the allotment as equal as possible for every member. If this plan had been carried out, the proprietorship over the family property of each kabaru today would be clearer and each kabarụ might be more independent of one another. However, in actuality the plan miscarried and the Mundabețtu guttu has through today kept its family property undivided. As a result, both the actual form and the members' image of the kuțuma of the Mundabețtu guttu have, in a sense, remained as those of the pre-Aliyasantana Act.

In addition to the miscarriage of Muttaya's plan, there was another factor that obstructed the partition of the family property of the Mundabettu guttu. At the time of Muttaya Shetty, three senior women (two called Anthakke and one called Rukku) were selected as the representatives of each of the major kabarụs and were registered as pațtadārti at the Revenue Board. ${ }^{17}$ Within just one or two generations after these three women, however, the succession and registration of pațtadārti stopped. This means, because nobody was registered after them, the names of the last successors - all of whom have already died - have become 'frozen' as the registered patțadārti of the family property. Because of the un-renewed registration of the pattadārti, each living member's right to the family property has become highly obscure. In such conditions, as we will see in the next chapter, the Mundabețu 


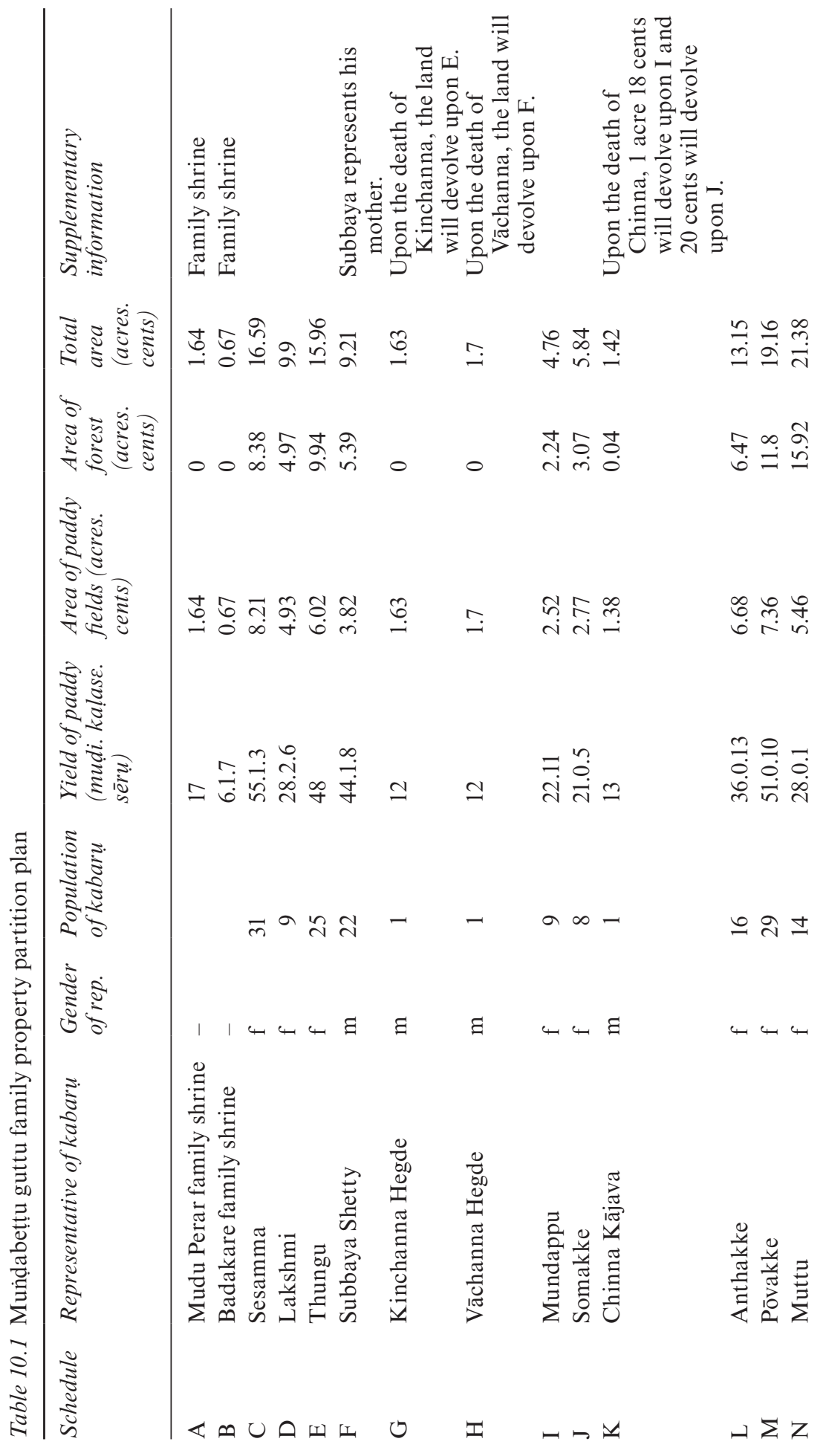




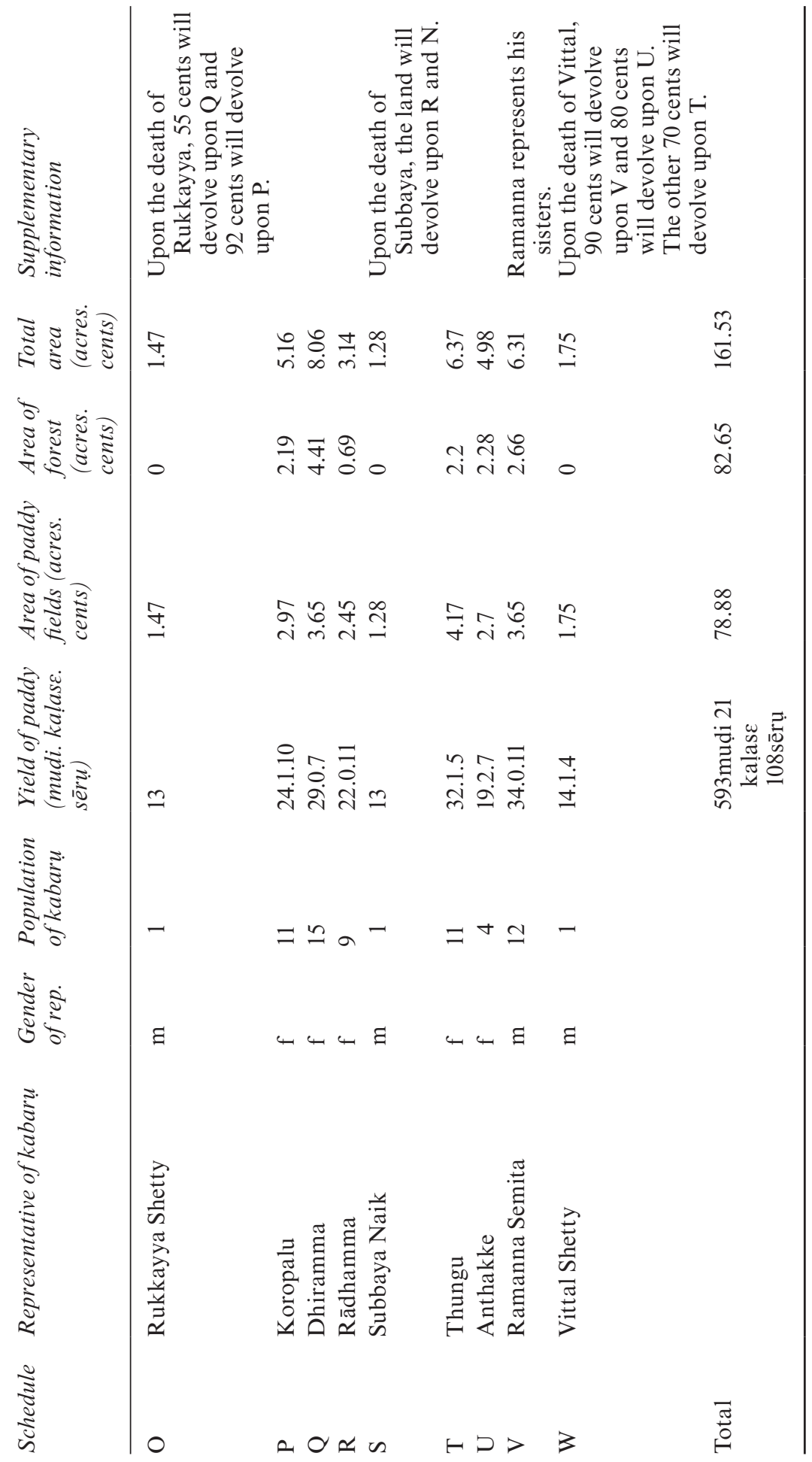


guttu has since 1974 also dealt with the legislation of the Karnataka Land Reforms (Amendment) Act. Before considering this issue, however, next I will examine the partition plan of the 'grandfather's land' of a kabaru in the Muṇ̃abețtu guttu.

\section{Following the kutuma, coping with modern law}

As discussed above, 'grandfather's land' is the land previously purchased by one of the matrilineal family members. The land is generally inherited to the purchaser's sisters and thus becomes part of the joint property of his mother's kabaru. Below, I will examine the case of the division of the 'grandfather's land' purchased by the maternal uncle of Ishwara Shetty, the pergaḍe of the Mundabețtu guttu prior to Muttaya Shetty.

According to Harish Shetty, one of the core members of the Mundabețu guttu, the maternal uncle of Ishwara Shetty was originally the mūla gēni of the Pejjāvara Mutt. As we will see in the next chapter, mūla gẹni refers to an 'original tenant' who has cultivated some particular land for generations and has relatively strong rights to the land compared with ordinary tenants. The uncle paid some amount of money to the matha and gained ownership (müla hakku) of the land. After his death, this land was inherited by one of his sisters, Ishwara Shetty's mother. The partition plan for this land arose for Ishwara Shetty's sisters' children's generation. Ishwara Shetty had three sisters, Rukku, Muttu, and Munjappu. Munjappu had no child, so only the descendants of Rukku and Muttu were concerned regarding land inheritance. In 1949, this land was divided and inherited by the kabarus of their daughters: Rukku's daughters Sesamma, Kusamma, and Anthakke; and Muttu's daughter Lakshmi. Based on the janasankyepālụ (division by population), each woman gained an allotment for her and her matrilineal descendants.

The partition of the land, however, did not go smoothly. Before the land was divided and inherited by these four kabarụs, Antappa Shetty, who was the eldest son of Rukku, contrived to register this land in the name of his wife. If the land were registered in the name of Antappa's wife, no other descendants of Rukku and Muttu could execute any rights to it. Against this scheme, however, Sesamma's husband objected strongly, and the land partition and inheritance to the four women's kabarụs was carried out. At the time of registration, a photograph of the four women, their husbands, and their children was taken for 'proof' that should prevent any further trouble concerning the land. The land purchased by the matrilineal uncle of Ishwara Shetty was thus finally partitioned and registered in the name of the four women.

As seen above, since the 1950s, members of the Mundabețu guttu endeavoured to partition and inherit the joint property of the kutuma. This was an attempt to confirm each member's rights in the allotment, and to avoid disputes among kin over the land. The partition and registration of the traditional family land, however, was never accomplished and the land rights of each member remain highly ambiguous. Meanwhile, in the case of the 
'grandfather's land', land partition and registration has been executed, but this was often accompanied by conflict among kin. The reason the 'grandfather's land' could be partitioned successfully was that the land belonged solely to the purchaser's mother's kabaru, and thus the number of kin concerned with this land inheritance was limited.

As explored above, modern law after independence has compelled the members of the Mundabețtu guttu to verify their land rights in conformity with modern law. For this purpose, it became necessary for them to understand every aspect of the joint property, to calculate the value of each plot, and to compare them to each other. In addition, as shown in Muttaya Shetty's plan, in order to allocate plots appropriately to each member of the kutuma, it was necessary to confirm the genealogy of the kutuma, to group the kabarus clearly, and to redefine each individual's position in the kutuma. In this sense, the partition plan of the joint family property was the Mundababtțu guttu's endeavour to reorganise both the kutuma and its property in relation to each other.

The Madras Aliyasantana Act, therefore, did not simply redefine and stipulate the customary aḷiyasantāna kațtụ. Rather, it compelled people to reconstruct and substantialise the category of matrilineal family and the proprietorship of each group and individual in conformity with modern law. In the case of the Mundabețu guttu, however, the partition plan for the traditional family land has not been accomplished, and the land rights of the kuṭuma members have remained obscure. Consequently, in the Mundabețtu guttu, modern law has not really promoted the distribution of the joint property or the division of the kabarụs; indeed, the 'wholeness' of the kutuma as a multiple community is still maintained today (see Ishii 2014b).

For the kuțuma members, this has a double meaning: the kutuma as a multiple community, which is based on vast family land and būta worship, is the ideal form of the kutuma as the basis and core of their lives. At the same time, since the joint property has never been partitioned, no member can fully exercise his/her right to an allotment. Thus, in between duty to the kutuma and ambitions for individual rights, people have taken various measures to cope with problems concerning land proprietorship. Especially when the Karnataka Land Reforms (Amendment) Act was enacted in 1974, the landowners - most of them actually just the representatives or managers of part of the family land - strived to establish their land rights. In the next chapter, I will investigate people's various efforts regarding these Land Reforms, focusing on the relations between the tenants and the landowner.

\section{Notes}

1 From the 1880 s, several judges began to convey their doubts about the authority of Bhuthala Pandya's kattụ, owing to the influence of Arthur Coke Burnell's criticism of the pamphlet. Burnell was the Judge of the District Court from 1872 to 1874 and was the author of the first English book on büta worship (Navada \& Fernandes 2008).

2 Subba Hegade v. Tongu, (1869) 4 Madras High Court Reports, 196. 
3 Yajamāna and yajamāni are the Kannaḍa words equivalent to yajamāne and yajamāni in Tuḷu, respectively.

4 For instance, in the court case held at the Madras High Court in 1890, the bench judged that a lunatic woman, Puttamma, who was the last survivor of an Aliyasantana family, should be entitled to the family property, rejecting the appeal of the wife and children of the last male survivor of Puttamma's family (Sanku v. Puttamma, 1891, Indian Law Reporter 14, Madras, 289). Also, in a court case held in 1910, the judge stated that it was reasonable to remove the elder sister, who had only one son, from the position of yajamāni and instead appoint the younger sister who had numerous children, from the viewpoint of family interests (Thimmakke v. Akku, 1911, Indian Law Reporter 34, Madras, 481).

5 Most research on matriliny in South India has dealt with marumakkattāyam, the form of matriliny that prevailed among the Nayars in Kerala. In both the academic literature and legal documents, the aliyasantāna kattu in South Kanara has often been defined through a comparison with marumakkattāyam, as its 'sister system' (Bhat 2004, p. 11). It is generally considered that in both aḷiyasantāna kațtu and marumakkattāyam, descent is traced in the female line. Also, the basic unit in the matrilineal society is the joint family called taravātŭ in Malayālam, kuṭumba in Kannaḍa, and kuṭuma in Tuḷu (see Gough 1952, p. 72).

6 See Moore (1985, p. 531) and Menon (1993) on the case in Malabar. It is also believed that if the kuțuma do not conduct the butta ritual properly, the family members who are responsible for the ritual must suffer the curse of the bütas.

7 When the Madras Aliyasantana Act was enacted in 1949, it was determined that this Act would remain in effect for 15 years and that from that point forward the per stirpes mode of division would be applied uniformly. In 1962, however, the Madras Aliyasantana (Mysore Amendment) Act, 1961, was enacted, and the mode of division was changed to per capita.

8 In Kannaḍa, saṃtati means 'group', 'offspring', and 'lineage', while nissamtati means 'childless'. See Učida and Rajapurohit (2013, pp. 589, 897).

9 Prior to this Amendment Act, the Hindu Succession Act was enacted in 1956. In the Hindu Succession Act, it was declared that when a member of a kutumba or kavalu who had rights to the undivided family property died, his/her allotment should be what the person would have received if the per capita mode of division had been accomplished just before his/her death; also, the allotment of the deceased person should be succeeded to his/her descendants whether he/she was a member of a nissamtati kavalu or not. In the Hindu Succession Act, even though the heirs of the deceased person could be entitled to the predecessor's allotment, the person concerned could not enjoy his/her allotment during his/her lifetime. See Bhat (2004, pp. 127-128).

10 Santhamma v. Neelamma, (1956) All India Reporter, Madras, 642.

11 Similarly, Bhat pointed out that people's rights in family property had been individualised by the amendment of law, and that under the recent social and economic change, the 'traditional Aliyasantana law is on the wane' (2004, pp. 164, 189).

12 Kabaru is the Tulu word equivalent to kavalu in Kannada.

13 The manager of the büta ritual at the family level is called the malpāvunāye, while the one at the village level is called the tüvonunaye.

14 Kaveri v. Ganga Ratna, (1956) 1 Madras Law Journal, 98.

15 'Muḍi gēni' is a unit of the weight of paddy paid as rent. One muḍi is approximately $39.2 \mathrm{~kg}$ (1 mudi corresponds to 3 kalase or to 42 sērụ). In the above case, the total weight of paddy that the Mundabettu guttu got yearly from all the tenants/cultivators was 600 mudi (approximately 23,520 kg). 
182 Social transformations, emergence of new umwelt

16 This system for the partition of family property is not unique to the Mundabetțu guttu, but is popular among the Banța families in Perar even today.

17 Anthakke, from the first major kabaru, was the sister of Muttaya Shetty, and Rukku, from the second major kabaru, was the sister of Ishwara Shetty. According to the records of land registration ( patte) kept in the Deputy Commissioner's Office, Anthakke from the first major kabarụ and another Anthakke from the third major kabarụ were registered as pațtadārti, in 1938 and 1950, respectively. 


\section{Land reforms and deities as the 'owners of land'}

As we have seen up to the previous chapter, various laws and policies on land tenure and matrilineal joint families were effected in South Kanara from the colonial to post-independence periods, and the people were required to respond to these measures. By contending with the new measures, the people reorganised the traditional systems of matriliny, land tenure, and the joint family or kuțuma. At the same time, however, they engaged in practices which did not necessarily adhere to the definitions of 'Aliyasantana system', 'kutumba', and 'land ownership' under modern law. In this sense, there was a reflexive interrelation, as well as slippage and mutual tension, between legal and political measures pertaining to the Aliyasantana system, land tenure, and joint family on the one hand, and the people's practices on the other.

As we saw in Chapter 9, from the time of introduction of the ryotwari system to the enactment of the Karnataka Land Reforms (Amendment) Act in 1974, most of the rights of existing landlords remained intact in South Kanara in spite of execution of various land policies. In order to understand the reasons for this more fully, we need to analyse the land reforms and the continued rights of the landlords not only from a politico-economic perspective, as we have done in Chapter 9, but also from the viewpoint of people's practices at the micro level. Focusing on the people's practices leads us to ask the following questions: what was the relationship between landlords, who had privileged rights to management and control of land based on execution of būta rituals, and other farmers? How were the būtas, intimately linked to land and nature as the 'owners of land', intertwined with people's practices concerning land reform?

In this chapter, I focus on the Karnataka Land Reforms (Amendment) Act of 1974, and examine negotiations between landlords and tenants over land rights, as well as people's attempts to maintain or gain land rights by taking up cases in Mudu Perar. First, I will give an outline of tenants and domestic labourers in the village. I will also reconstruct an approximation of caste constitution of landlords, tenants, and domestic labourers before land reform, based on results of the household survey I conducted. Next, I will analyse the characteristics of land tenure and inheritance pattern of matrilineal families, focusing on cases of Banța landlords. Last, I will discuss concrete instances of how the landlords dealt with land reforms, and 
how būta rituals were involved in negotiations and conflicts between landlords and tenants over land rights.

\section{Tenants and domestic labourers in Perar}

\section{Two types of tenants: mūla gēni and cāla gēni}

In Perar prior to land reform, people who worked on the landlords' land were collectively called okkelu. They were further divided into two categories, gēni okkelụ and kāli okkelụ. Gēni okkelụ referred to 'tenants', who cultivated land rented from landlords, and paid the landlords farm rent ( $g \bar{e} n i$ ) in the form of rice. Kāli okkelụ were 'domestic labourers', who lived on the landlords' land, engaged in farm work, took care of cattle, and so on.

Gēni okkelụ were further divided into mūla gēṇi and cāla gênni. ${ }^{1}$ Mūla gēni meant 'old-time/original tenants' and referred to families of tenants working on particular land over several generations. Landlords could not drive out mūla gēni or exchange them for other tenants. The tenant rights of mūla gēni were stable and hereditary, unlike those of cāla gēnii. ${ }^{2}$ Cāla gēṇi were 'mobile tenants', who had gained tenant land relatively recently and were employed on the basis of annual or seasonal contracts. The landlords could change the rent or evict them. The majority of tenants working on landlords' land before land reform in Perar were cāla gēni. ${ }^{3}$

\section{Domestic labourers (kāli okkelü)}

Domestic labourers (kāli okkelụ) lived on the landlords' estates and performed a variety of work, including farming, taking care of cattle, collecting fodder, and managing forests. Unlike tenants (gēni okkelụ), who cultivated landlords' land and paid the landlords a part of the produce as land rent, domestic labourers could not gain products of the land they cultivated themselves; hence, they did not pay landlords any land rent. Landlords are said to have given around 1-2 kilograms of rice per day for a family of five to six persons as payment for the work of domestic labourers. ${ }^{4}$ Domestic labourers and their families were provided housing on the outskirts of a landlord's estate or in forests owned by a landlord. These were usually very humble dwellings with mud walls and thatched roofs. One house was shared by about five families with one family occupying a single room each. Such houses often collapsed during the monsoon season, and labourers were sometimes made to live in the landlords' cowsheds.

After the enforcement of land reforms from around 1977 to the 1980s, many domestic labourers and their families moved to small plots of land 5 cents in size provided by the government and became daily wage labourers. Some families, however, continued to live in their homes on the landlords' land after this period because they could not afford to buy a plot of land for 5 cents and build a house there. 


\section{Land reforms in village society: registration records of application of land rights}

In this section, I will give an overview of the application of land rights in Mudu Perar based on administrative records at the time of land reforms preserved in the Deputy Commissioner's office in Mangaluru. The records I refer to are those documented in the Villagewar Resister of Applications Filed under Section 48-A before the Tribunal (VRA) submitted to land tribunals between 1974 and 1979 .

According to VRA, there were 379 applications in total for land in Mudu Perar between 1974 and 1979, and the total area applied for was 918.08 acres. $^{5}$ The majority of applicants were Muslims, constituting half of the total. This corresponds to the fact that a mosque constituted the most numerous type of landlord (a total of 149 cases) (Table 11.1). In VRA, we find many cases of inhabitants of the Muslim residential area, Guru Kambula, applying for a part of the holding of the mosque located there from the end of 1975 to 1979.

Table 11.1 Types of applicants and landlords

\begin{tabular}{|c|c|c|}
\hline & Type & Number \\
\hline \multirow[t]{15}{*}{ Applicants } & Muslim & 189 \\
\hline & Christian & 55 \\
\hline & Pūjāri & 35 \\
\hline & Baṇta & $30^{*}$ \\
\hline & Kuḍubi & 27 \\
\hline & Unknown & 14 \\
\hline & Moyli & 8 \\
\hline & Brahman & 7 \\
\hline & Ācāri & 7 \\
\hline & Other Hindus & 3 \\
\hline & Baṇụāi & 1 \\
\hline & Dēvaḍige & 1 \\
\hline & Konkani & 1 \\
\hline & $\mathrm{SC}$ & 1 \\
\hline & Total & 379 \\
\hline \multirow[t]{14}{*}{ Landlords } & Mosque & 149 \\
\hline & Baṇța & 92 \\
\hline & Muslim & 41 \\
\hline & Temple/mutt & 26 \\
\hline & Unknown & 22 \\
\hline & Christian & 13 \\
\hline & Brahman & 12 \\
\hline & Catholic church & 11 \\
\hline & Konkani & 8 \\
\hline & Other Hindus & 2 \\
\hline & Kuḍubi & 1 \\
\hline & Pūjāri & 1 \\
\hline & Moyli & 1 \\
\hline & Total & 379 \\
\hline
\end{tabular}

* Ten of these are members of the Mundabețtu guttu. 
Table 11.2 Types of Baṇta landlords

\begin{tabular}{lc}
\hline Banța landlord family & Number \\
\hline Muṇdabețtu guttu & 43 \\
Other Baṇta & 36 \\
Tidyamuṇdoț̣ guttu & 7 \\
Alake guttu & 6 \\
Total & 92 \\
\hline
\end{tabular}

In most cases, the inhabitants each applied for a very small plot of land, less than 1 acre. Hence we see that in this period, vast land owned by the mosque was distributed to Muslim households in Guru Kambula. In the same way, we see from Table 11.1 that land owned by temples, mutts, and Catholic churches, such as Sri Venkatramana Temple and Pējāvara Mutt, were also distributed to tenants through land reforms. ${ }^{6}$

The second most numerous landlords were the Banta (92 cases). As we see in Table 11.2, 43 families were the Mundabettu guttu, followed by other Banța (36 cases), the third guttu house Tidyamundotoțu guttu (7 cases), and the fifth guttu house Alake guttu (6 cases). Hence, it seems that among landlords, excluding religious institutions, the Banța, particularly those of the Mundabețțu guttu, were greatly affected by land reform.

Interestingly, however, there were comparatively more Banța applicants for land rights ( 30 cases) of which 10 belonged to the Mundabețu guttu family. From this, we note that though the land reforms led to transfer of land from landlords to tenants to some extent, village landlords/landed farmers also tried to establish their land rights by applying to land tribunals, and transferred land among themselves. Moreover, if we look at the details of the Mundabețtu guttu's holdings that were subject to applications, the most numerous were land purchased by a member of the matrilineal family, called 'grandfather's land', constituting 21 out of 43 cases (Table 11.3). This indicates that not only did tenants acquire 'grandfather's land', but members of the sub-matrilineal joint family (kabaru), who collectively owned the land, also applied for rights over this type of land.

Table 11.3 Types of land applied for rights in the Munịabețtu guttu

\begin{tabular}{ll}
\hline Type of land & Number \\
\hline 'Grandfather's land' & 21 \\
Traditional family land & 12 \\
Purchased farmland & 10 \\
Total & 43 \\
\hline
\end{tabular}




\section{Group composition of landlords, tenants, and domestic labourers in Mudu Perar}

What kinds of people, then, were landlords, tenants, and domestic labourers in Perar before land reform? In this section, I reconstruct an approximation of the group composition of each of these three categories, and examine their details based on the door-to-door household survey I conducted in Mudu Perar.

\section{Methods and subjects of the survey}

Before examining the details, let me explain the methods and subjects of the survey. I surveyed 227 households (total population 1,082) in Mudu Perar from 18 July to 28 August 2008. ${ }^{7}$ I visited each household with questionnaires and carried out interviews along with my research assistant, Ms Akshaya Shetty. Sometimes Akshaya's father, Mr Harish Shetty, accompanied us as a guide and introduced me to the interviewees. We conducted the survey during the monsoon season, so we walked to the houses in the village every day in the pouring rain, passing through fields that had sunk underwater and had become like ponds, crawling up mountain roads covered by bushes, occasionally slipping and falling on footpaths between fields. Most of the villagers were acquaintances of Harish and Akshaya, and were happy to answer questions when I explained my intentions.

The survey was conducted mainly in Hindu residential areas in Mudu Perar. Out of the 227 households I surveyed, 219 households were Hindu and they constituted $31.8 \%$ of the Hindu households (total 689 households) in Mudu Perar. Table 11.4 shows the numbers of households by caste and group. As we can see in the table, the caste constitution of 227 households is similar to that in Mudu Perar which I discussed in Chapter 2.

Table 11.4 Caste/group of households and population*

\begin{tabular}{lcc}
\hline Castelgroup & Number of households & Population \\
\hline Kuḍubi & 79 & 436 \\
Baṇta & 56 & 203 \\
Pūjāri & 47 & 224 \\
Ācāri & 9 & 61 \\
Moyli & 8 & 37 \\
Catholic & 8 & 25 \\
SC* & 5 & 25 \\
Belcad̦e & 5 & 25 \\
Brahman & 4 & 15 \\
Purușa & 3 & 18 \\
Bañūāi & 2 & 9 \\
Mūlya & 1 & 4 \\
Total & 227 & 1,082 \\
\hline
\end{tabular}

* SC in Table 11.4 are Mansa and those who call themselves harijana, but their exact caste name is unknown. 


\section{Group composition of landlord households}

Forty-three households out of the 227 households I surveyed were landlords before enforcement of the Karnataka Land Reforms (Amendment) Act in 1974, constituting approximately $18.9 \%$ of the total. ${ }^{8}$ Table 11.5 a shows the numbers of these 43 households by caste and group. As we can see from the table, 40 households, approximately $93 \%$ of the landlord households, are Banța. If we look at the details of the families of Banta households (Table 11.6), we see that 19 households, constituting $47.5 \%$, belong to the Muṇ̃abețtu guttu.

Table 11.5 Number of (a) landlord households, (b) tenant households, (c) domestic labourer households, and (d) other households by caste/group

\begin{tabular}{|c|c|c|c|c|}
\hline & & Caste/group & $\begin{array}{l}\text { Number of } \\
\text { households }\end{array}$ & $\%$ \\
\hline \multirow[t]{4}{*}{ (a) } & \multirow[t]{4}{*}{ Landlord households } & Baṇṭa & 40 & 93.0 \\
\hline & & Brahman & 2 & 4.7 \\
\hline & & Catholic & 1 & 2.3 \\
\hline & & Total & 43 & 100 \\
\hline \multirow[t]{7}{*}{ (b) } & \multirow[t]{7}{*}{ Tenant households } & Kuḍubi & 27 & 39.7 \\
\hline & & Pūjāri & 18 & 26.5 \\
\hline & & Banța & 8 & 11.8 \\
\hline & & Ācäri & 6 & 8.8 \\
\hline & & Catholic & 4 & 5.9 \\
\hline & & Others* & 5 & 7.4 \\
\hline & & Total & 68 & 100 \\
\hline \multirow[t]{8}{*}{ (c) } & \multirow{8}{*}{$\begin{array}{l}\text { Domestic labourer } \\
\text { households }\end{array}$} & Kuḍubi & 40 & 55.6 \\
\hline & & Pūjāri & 17 & 23.6 \\
\hline & & Moyli & 7 & 9.7 \\
\hline & & Baṇța & 3 & 4.2 \\
\hline & & Puruṣa & 2 & 2.8 \\
\hline & & Belcade & 2 & 2.8 \\
\hline & & $\mathrm{SC}$ & 1 & 1.4 \\
\hline & & Total & 72 & 100 \\
\hline \multirow[t]{12}{*}{ (d) } & \multirow[t]{12}{*}{ Other households } & Kuḍubi & 12 & 30.0 \\
\hline & & Pūjāri & 12 & 30.0 \\
\hline & & Ācāri & 3 & 7.5 \\
\hline & & Belcaḍe & 3 & 7.5 \\
\hline & & Baṇta & 2 & 5.0 \\
\hline & & Catholic & 2 & 5.0 \\
\hline & & $\mathrm{SC}$ & 2 & 5.0 \\
\hline & & Moyli & 1 & 2.5 \\
\hline & & Mūlya & 1 & 2.5 \\
\hline & & Banḍāri & 1 & 2.5 \\
\hline & & Brahman & 1 & 2.5 \\
\hline & & Total & 40 & 100 \\
\hline
\end{tabular}

* Caste of 'Others': SC 2, Brahman 1, Purușa 1, Baṇḍāri 1. 
Table 11.6 Families of Banța landlord households

\begin{tabular}{lcc}
\hline Baṇta household affiliation & Number of households & $\%$ \\
\hline Muñạabețtu guttu & 19 & 47.5 \\
Other Baṇța & 13 & 32.5 \\
Alake guttu & 4 & 10.0 \\
Tidyamuṇdoțț guttu & 4 & 10.0 \\
Total & 40 & 100 \\
\hline
\end{tabular}

\section{Group composition of tenant households}

Out of the 227 households surveyed, 68 households were tenants (gēni okkelụ) before land reform. ${ }^{9}$ Table $11.5 \mathrm{~b}$ shows the numbers of these 68 households by caste and group. Forty-five households, constituting approximately $66 \%$ of the total, are Kuḍubi and Pūjāri, followed by Baṇța and Ācāri, and Catholic.

\section{Group composition of domestic labourer households}

Seventy-two households out of 227 were domestic labourers (kāli okkelụ) before land reform. ${ }^{10}$ Table $11.5 \mathrm{c}$ shows the numbers of 72 households by caste. Just as in the case of tenant households, Kuḍubi and Pūjāri households are the most numerous, as 55.6\% are Kuḍubi, followed by Pūjāri, Moyli, and Baṇtạ.

\section{Group composition of other households}

Of the 227 households, 40 households were not landlords, tenants, or domestic labourers before land reform (Table 11.5d). Among these, 26 households live on housing sites 5 cents in size developed by the government after the 1970s. Adult members of these households were daily wage labourers engaged in agriculture or other work before land reform, and were not live-in domestic labourers.

From the above, we see that the socio-economic structure of Mudu Perar before land reforms was such that while the Banta occupied much of the farmland and forests, Kudubi and Pūjāri engaged in the actual farm labour as tenants and domestic labourers.

\section{Characteristics of land holding and inheritance among the Banța landlords}

\section{Land holdings and acquisitions by the landlord households}

Next, I will analyse the land holdings of landlord households in Mudu Perar. Table 11.7 shows the area of holdings of 43 households in 2008, who had been landlords before land reform. 
Table 11.7 Area of land holdings of landlord households (2008)

\begin{tabular}{lccc}
\hline (Unit: acre) & Farmland & Forest & Total \\
\hline Total area & 129.41 & 201.05 & $333.96^{*}$ \\
Average area** & 3.16 & 4.9 & 7.77 \\
\hline
\end{tabular}

* Total calculated by adding 3.5 acres of total holdings of two households, whose type of land is unknown, to the total of farmland and forest.

** Average area of farmland and forest excludes two households whose type of holdings is unknown.

As we see in Table 11.7, the total holding of landlord households is approximately 334 acres. The average holding of each household is approximately 7.8 acres, including farmland and forests. How did these households acquire land? Table 11.8 illustrates the manner of land acquisition by these 43 households.

As Table 11.8 shows, holdings of many landlord households were a part of traditional family land of the kutuma, or land bought in the past by a matrilineal family member that later became a part of joint holdings of the kabaru to which the buyer belonged ('grandfather's land'). With the exception of five households who acquired land through purchase by the present head of household before land reform (four Banțas, one Catholic), and two Brahman households who only inherited land bought by the father, the rest of the landlord households (Banta) have all inherited a part of the traditional family land or 'grandfather's land'.

Table 11.8 Classification of holdings of landlord households according to manner of acquisition

\begin{tabular}{lcc}
\hline Manner of land acquisition & $\begin{array}{l}\text { Number of } \\
\text { households }\end{array}$ & \% \\
\hline $\begin{array}{l}\text { Matrilineal inheritance of traditional family land } \\
\text { Traditional family land + matrilineal inheritance of land }\end{array}$ & 16 & 37.2 \\
$\quad \begin{array}{l}\text { purchased by matrilineal family member } \\
\text { Purchase before land reform }\end{array}$ & 5 & 20.9 \\
$\begin{array}{l}\text { Traditional family land + inheritance of land purchased by } \\
\quad \text { maternal grandfather or maternal great grandfather }\end{array}$ & 4 & 11.6 \\
$\begin{array}{l}\text { Traditional family land + acquisition due to land reform } \\
\text { Inheritance of land purchased by father }\end{array}$ & 3 & 9.3 \\
$\begin{array}{l}\text { Traditional family land + purchase before land reform } \\
\text { Traditional family land + purchase before land reform + }\end{array}$ & 2 & 7.0 \\
$\quad$ acquisition due to land reform & 1 & 4.7 \\
$\begin{array}{l}\text { Traditional family land + 'grandfather's land' + } \\
\quad \text { inheritance of land purchased by father }\end{array}$ & 1 & 2.3 \\
'Grandfather's land' only & 1 & 2.3 \\
Total & 43 & 2.3 \\
\hline
\end{tabular}

1 Abbreviated as 'traditional family land' in this table.

2 Abbreviated as 'grandfather's land' in this table.

3 Landlord households who acquired land due to land reform were tenants of other landlords before the reform. 
In this way, in Mudu Perar, many household heads, who were landlords before land reform, are either inheritors or managers of a part of the land holding of the matrilineal family. It should be pointed out that as we saw in the case of the Mundabettu guttu in Chapter 10, present-day inheritors or managers of each plot in the kutuma are not necessarily officially registered as the holders. Hence those whom we have referred to until now as 'landlords' are not 'land owners' with legal and exclusive rights to a plot of land, but rather the representatives of the plot jointly held by the kutuma. Below I will examine land tenure among the Banta landlord households based on concrete cases.

\section{Inheritance of traditional family land and 'grandfather's land'}

Case 1 Inheritance and management of family land registered in the name of a deceased person

Banța, Alake guttu family. Household composition: Sampavati (77-yearold, female), her eldest son Vittal, his wife and children. The household owns 3 acres of farmland and 7 acres of forest. These lands are all holdings of the matrilineal joint family, but are registered in the name of Sampavati's deceased mother, and have not been divided or registered anew by succeeding generations. The total of 10 acres of land is presently managed by Vittal and its income is consumed by only this household.

Case 2 Inheritance and management of family land registered in the name of a deceased person

Banța, Alake guttu family. Household composition: Bālākrishna (36-year-old, male), his wife and children. The household owns 5 acres of land. Bālākrishna's mother had matrilineally inherited this land, but it is registered in the name of the elder sister of Bālākrishna's maternal great-grandmother (MMMZ). Bālākrishna's maternal uncle used to manage the land before Bālākrishna took over.

Cases 1 and 2 show how family land (or a part of it) is registered in the name of a deceased (female) member of the matrilineal family, inherited by the eldest woman who represents a kabarụ, and managed by the woman's brother or son. As we see in Case 2, the management rights of land usually pass from the brother of the woman who inherits the land to her son.

Case 3 Various types of matrilineal inheritance by a female landlord

Banța, Mundabețu guttu family. Household composition: Devaki (82-yearold, female) and her daughter. Devaki owns approximately 2 acres of land inherited matrilineally; 2.5 acres jointly held by the offspring of Devaki's mother and the offspring of Devaki's mother's sisters; and approximately 3 acres purchased in the past by a matrilineal family member ('grandfather's land'). In addition, she used to own approximately 7 acres located outside Mudu Perar purchased by the matrilineal family.

i Land inherited matrilineally: this 4-acre land was owned by Devaki's mother, Sesamma, and was subsequently divided and inherited by Devaki and her sisters. At present, the land of all 
three sisters is managed by Devaki's eldest son, and its income converted into cash and distributed to the sisters.

ii Land owned by the offspring of Sesamma and the offspring of Sesamma's sisters: this land is part of a joint holding of the kabarụ headed by the mother of Sesamma and her sisters.

iii and iv 'Grandfather's land': these plots are part of the land purchased by the maternal uncle of Devaki's maternal grandmother (MMMB). Seven acres of land located outside Mudu Perar was transferred to a Kudubi tenant after land reform.

This is a case of the eldest woman of the kutuma inheriting and owning several holdings, including both traditional family land and 'grandfather's land'. There is a tendency among the Banta for women belonging to the kuṭuma to inherit a lot of land and accumulate holdings, as land purchased by a matrilineal family member (male) is passed on to the buyer's sisters and their daughters along the matriline.

\section{Inheritance from father to son among the Banta}

Table 11.8 shows that four households (all Bantas) have inherited and own land purchased by the maternal grandfather (MF) or maternal great grandfather (MMF) in addition to inheriting the traditional family land. Among the Bantas, the maternal grandfather and the maternal great grandfather belong to different kuṭumas from the successor. Hence inheriting land purchased by them is a different mode of inheritance from the usual matrilineal one. Let us examine this mode of succession below.

Case 4 Inheritance of family land and of land purchased by maternal grandfather

Banța, Muñdabettu guttu family. Household composition: Jayashila (67-yearold, male), his elder sister Rohini, Rohini's daughter, and Rohini's daughter's children. They own matrilineally inherited land of 4 acres 86 cents and farmland purchased by the maternal grandfather yielding 21 muḍi.

i Land inherited matrilineally: when Anthakke, the maternal grandmother of Jayashila and Rohini, was alive, the kutuma elders at the time promised that Anthakke's daughter Lamakke (mother of Jayashila and Rohini) and her sister Manjakke would divide and inherit the land. The land owned by Jayashila and Rohini at present is part of the land that their mother Lamakke inherited.

ii Land purchased by the maternal grandfather: this land is part of the land yielding 100 mudii (approximately 60 acres) purchased by Appanna Rai, the husband of Jayashila's maternal grandmother, Anthakke. This land was inherited by his children, the sisters Lamakke and Manjakke, in accordance with Appanna's will. Out of this 60-acre land, Jayashila manages the plot yielding 21 mudi and Manjakke's son manages the 
plot yielding 63 mudi at present. The remaining land was acquired by a Catholic tenant at the time of land reform.

The above is a case of a Banta family where a part of the family land of the kutuma to which the household head belongs is inherited matrilineally, while land purchased by the maternal grandfather of the household head is inherited by his own children and their offspring. As we have already seen, among the matrilineal Banta, land purchased by a male member of the matrilineal family becomes part of the family land, as it is inherited not by his own children but by his sisters and their offspring. However, in Case 4, it was possible for Appanna Rai's daughters, belonging to a different kuṭuma from him, to inherit the land he purchased because he left a will. Such mode of inheritance whereby the children inherit land purchased by their father diverts from the traditional matrilineal inheritance among the Banta. ${ }^{11}$

Case 5 Inheritance of family land and of land purchased by maternal great grandfather

Banța, Mundabettu guttu family. Household composition: Single person household of Sumati (67-year-old, female). Sumati currently owns approximately 4 acres 60 cents of land she inherited matrilineally. Before land reform, she owned 2 acres of matrilineally inherited farmland in Mudu Perar, and had usufruct of 3 acres out of 25 acres of family land outside the village. Before land reform, Sumati also owned farmland that yielded 42 muḍi (approximately 8 acres) in Mudu Perar. This land was purchased by the husband of her maternal great grandmother, Unnyakke, but was transferred to a Pūjāri tenant at the time of land reform.

In the above case, the eldest woman, the household head, matrilineally inherits the holdings of the kuțuma she belongs to, and at the same time inherits land purchased by her maternal great grandfather. The latter was passed from her great grandfather to her grandmother, and then to her mother before her. Land purchased by a man of the matrilineal family ('grandfather's land') can be inherited matrilineally, or it can be directly inherited by the man's children and their offspring, as we saw in Cases 4 and 5. Inheritance from the father to his children can lead to discord between the members of the buyer's matrilineal family and his children, since land is inherited by members of a kuțuma other than that to which the buyer belongs.

Disputes between the landholder's children and the matrilineal family over inheritance occur not only in cases of land purchased by the holder himself. In the case below, we see how a conflict develops between a deceased landholder's elder sister and his child over land purchased by a matrilineal family member that later came to be divided and inherited.

Case 6 Conflict between the deceased landholder's sister and son over land

Household composition: Dinakara (Banta, 52-year-old, male), his wife and children. Dinakara's father, Narayana, owned a part of the 'grandfather's land', which had been purchased in the past by a member of the matrilineal family to which Narayana belonged. It was divided and inherited by 
Narayana and his brothers and sisters according to division by population (janasankkyєpālụ). After Narayana's death, his land was inherited by his elder sister (Dinakara's paternal aunt). This led to a dispute between Dinakara and his paternal aunt over the land, and they are currently involved in a lawsuit.

As we have already seen, the landlords, many of whom are Banta, owned farmland and forests in Mudu Perar before land reform. Many of them matrilineally inherited and own parts of traditional family land as well as 'grandfather's land'. Land holding and inheritance based on matriliny prioritises inheritance by women and grants authority and benefits to the women's brothers or sons as the managers of the land. There are cases where the child (most often the daughter) inherits land purchased by her father. Such cases, however, are few compared to those of matrilineal inheritance.

Traditional family land of a kuțuma often remains registered in the name of a kinswoman who died several generations ago. As in the case of the Munidabetțu guttu we discussed in Chapter 10, the larger the holding of a kuțuma, the less smooth the division, inheritance, and registration of land among the members, resulting in the continuation of joint holdings by the kutuma to the present day.

In this way, since land is not registered in an individual's name, or past registration is not updated, rights of family members to plots that are part of family land are not fixed, and individuals' rights are restricted. For instance, if a person matrilineally inherits a part of family land, he/she will not have rights to sell the land as real estate or borrow money from a bank by mortgaging it, unless the land is registered in his/her name. Due to this problem, land is often bought and sold within the kutuma without changing the name in the register, as we see below.

Case 7 Land transaction 'in private' without changing the name in the register

Banța, Mundabettu guttu family. Household composition: Harish (55-yearold, male), his wife and child. Harish owns 7 acres 75 cents of land at present. He purchased this land from a family member belonging to the same kutuma. The land is registered in the name of Harish's maternal grandmother, Sesamma. Two households, also direct descendants of Sesamma, had rights as joint managers. Harish purchased the land with permission from all the adult members of these two households and paid the money, but the land remains registered in Sesamma's name. Hence Harish fears the possibility of losing the land, if the offspring of the households who had management rights decide to claim their rights in the future.

In this way, land holding and inheritance based on matriliny enables maintenance and accumulation of land within the kutuma. At the same time, however, it leaves the rights of family members to each plot ambiguous. How were the Banta landlords that practised such methods of land holding and inheritance affected by land reforms, and how did they deal with the changes? Let us now turn to the relationship between landlords and land reform. 


\section{Enforcement of the Karnataka Land Reforms (Amendment) Act and the people's practices}

\section{Land reforms and landlords in Perar}

In the survey I conducted in Mudu Perar, out of the 43 households who were landlords before land reform, 15 households, constituting 34.9\% of the total, lost land due to the Land Reforms (Amendment) Act of 1974. Table 11.9 shows the area of land that each household (or kutuma to which the head of household belonged in cases where land was not divided) lost due to land reform, types of land based on how they were acquired, and their location. ${ }^{12}$

Table 11.9 Landlord households that lost land due to land reform

\begin{tabular}{|c|c|c|c|}
\hline $\begin{array}{l}\text { House } \\
\text { hold } \\
\text { number * }\end{array}$ & $\begin{array}{l}\text { Land area lost } \\
\text { due to land } \\
\text { reform (in acre) }\end{array}$ & Manner of acquisition & Location \\
\hline 38 & 1.5 & $\begin{array}{l}\text { Farmland purchased by } \\
\text { household head }\end{array}$ & Mudu Perar \\
\hline 47 & 0.16 & $\begin{array}{l}\text { Traditional family } \\
\text { land** (homestead) }\end{array}$ & Mudu Perar \\
\hline 146 & 2.1 & Traditional family land & Mudu Perar \\
\hline 147 & 0.43 & Traditional family land & Mudu Perar \\
\hline 148 & 10.38 & $\begin{array}{l}\text { Traditional family } \\
\text { land, land purchased } \\
\text { by maternal great } \\
\text { grandfather }\end{array}$ & $\begin{array}{l}\text { Inside and outside Mudu } \\
\text { Perar (family land), } \\
\text { outside Mudu Perar } \\
\text { (purchased land) }\end{array}$ \\
\hline 149 & $\begin{array}{l}1 \text { acre } \\
+ \text { land yielding } \\
26 \text { muḍi }\end{array}$ & $\begin{array}{l}\text { Traditional family land, } \\
\text { land purchased by } \\
\text { maternal grandfather }\end{array}$ & Mudu Perar \\
\hline 152 & $\begin{array}{l}1 \text { acre } \\
+ \text { land yielding } \\
200 \text { muḍi }\end{array}$ & Traditional family land & $\begin{array}{l}\text { Mudu Perar (1 acre), } \\
\text { outside Mudu Perar } \\
\text { (land yielding } 200 \\
\text { muḍi) }\end{array}$ \\
\hline 153 & Same as 152 & Traditional family land & Same as 152 \\
\hline 157 & 11.2 & $\begin{array}{l}\text { Farmland purchased by } \\
\text { household head's father }\end{array}$ & Mudu Perar \\
\hline 158 & 7 & 'Grandfather’s land' & Outside Mudu Perar \\
\hline 162 & 1.5 & Traditional family land & Mudu Perar \\
\hline 163 & 8 & $\begin{array}{l}\text { Land purchased by } \\
\text { maternal great } \\
\text { grandfather }\end{array}$ & Outside Mudu Perar \\
\hline 196 & 4 & Traditional family land & Mudu Perar \\
\hline 197 & Same as 196,198 & Traditional family land & Mudu Perar \\
\hline 198 & Same as 196,197 & Traditional family land & Mudu Perar \\
\hline Total & $\begin{array}{l}48.27 \text { acres }+ \\
\text { land yielding } \\
226 \text { mudii**** }\end{array}$ & & \\
\hline
\end{tabular}

* Serial number of each household in the survey.

** Includes joint holdings that are not divided.

*** Approximate average 3.22 acres + land yielding 15.1 muḍi. 
As we can see in the table, the total area of land the 15 landlord households lost due to land reform is 48.27 acres. The average area each household lost is approximately 3.22 acres. ${ }^{13}$ If we look at the different kinds of land according to the ways they were acquired, 12 households, that is to say, $80 \%$ of the total of 15 households, lost a part of family land (including both traditional family land and 'grandfather's land'). As for the location of the land, 13 households lost their land within Mudu Perar to tenants.

However, 28 households, constituting $65.1 \%$ of the total of 43 landlord households, have not lost land due to land reform. Also, as we saw in Table 11.7, landlord households currently own a total of approximately 334 acres of land, and each household owns an average of approximately 7.8 acres of farmland and forest. Thus, among the landlord households surveyed, there were more households who did not lose land due to land reform than those that did, and those who were landlords before land reform still maintain vast amounts of land. So how was it possible for the landlords to keep their land?

Before land reform, out of these 28 households, 4 households had no tenants (gēni okkelụ), and only employed domestic labourers (kāli okkelụ). Fifteen households used neither tenants nor domestic labourers, and out of these, the household heads of three households were tenants of other landlords. The remaining nine households employed tenants before land reform, but managed to evade transfer of land to the tenants because for some reason the tenants did not apply for land rights at the time of land reform. ${ }^{14} \mathrm{In}$ most cases, these households were able to keep land, in spite of the fact that they had tenants, either because the tenants had left the land of their own accord before the enforcement of the Land Reforms (Amendment) Act, or because they had evicted the tenants just before and after the enforcement of the Act. Let us examine concrete cases below.

Case 1 Landlords evicting tenants

Household composition: Ishwara (Banta, 75-year-old, male), his wife and children, and two grandchildren. This household owns 14 acres of farmland and forest purchased by Ishwara in 1968. There were tenants on the land before the purchase, but Ishwara asked them to leave before the enactment of land reform, and they did so. Hence he lost no land due to land reform.

Case 2 Conflict between landlords and tenants over application for land rights

Banța, Muñdabețu guttu family. Household composition: Mahabhara (85-year-old, male) and his wife Hemabati. They own 3 acres 40 cents of farmland and forest inherited matrilineally by Hemabati. They used to have a Catholic tenant and Kudubi domestic labourer before land reform. At the time of land reform, the Catholic tenant tried to apply for land rights, resulting in a dispute between the tenant and Mahabhara. Mahabhara paid the tenant some money and persuaded him to give up the application.

Cases 1 and 2 involve landlords evicting tenants and retaining their land rights at the time of enforcement of the Land Reforms (Amendment) Act of 1974. In both cases, the landlords drove the tenants off the land before the 
tenants applied for land rights. Below is a case where the landlords, who lost a part of land to a tenant due to land reform, evicted a tenant working on another plot of land in order to preserve their rights there.

Case 3 Landlords holding on to their land

Household composition: Lukumuni (Banta, 65-year-old, female) and her daughter. Lukumuni owns 2.5 acres of matrilineally inherited farmland and forest. Before land reform, Lukumuni's family lived in Kompadavụ, a village adjacent to Mudu Perar, but moved to Kokkar in Mudu Perar in 1976 because they had lost their holdings due to land reform. Lukumuni's maternal uncle, his wife and children had lived on the land owned by Lukumuni's matrilineal family in Kokkar, but after the maternal uncle died, Lukumuni's family paid the uncle's wife some money and made them leave the land. Later, a Kudubi tenant came to work on this land, but Lukumuni's family occupied the land before the tenant could apply for land rights and evicted the tenant. According to Lukumuni, her family evicted the Kudubi tenant because they feared that tenants would take over the land not only in Kompadavụ but also in Kokkar.

Case 4 Landlords evicting tenants

Banța, Mundabețtu guttu family. Household composition: Lalita (60-yearold, female) and her son. Four acres of land owned by the matrilineal family of Lakshmi, the mother of Lalita's deceased husband, was acquired by a Pūjāri tenant due to land reform. For this reason, Lakshmi's maternal uncle evicted the Pūjāri tenant from the land of which he himself was the landlord.

Case 5 Dismissal of tenants and use of short-term tenants

Banța, Mundabettu guttu family. Household composition: Ramani (84-yearold, female), her daughter, son, his wife and children. They own 5 acres of farmland and forest matrilineally inherited by Ramani, as well as 4 acres of forest and 3 acres of farmland purchased in 1993. An old-time Banta tenant worked on the matrilineally inherited land, but when the tenant died in 1968, his wife and child left the land. After that, Ramani's mother's siblings managed the land, and tenants came and went as they were employed on a short-term basis.

As we see from the above, some landlords fearing that the tenants would apply for land rights evicted them just before and after 1970, and held on to their land rights. Also, as we see in Case 5, some landlords took measures to ensure that particular tenants would not apply for land rights by dismissing tenants after a short term and continually changing the tenants they employed.

\section{Application for land rights by village landlords}

As I have already discussed, people who managed land and had rights to the products of that land did not necessarily establish their rights to the land by registering with the government. Rights of family members to joint holdings of the kutuma were ambiguous. As we will see below, the enforcement of 
the Land Reforms (Amendment) Act provided opportunities for them to fix their rights to parts of the family land by applying for land rights as landed farmers.

Case 1 Application for 'grandfather's land'

According to Villagewar Resister of Applications Filed under Section 48-A before the Tribunal (VRA), on 27 August 1974, Gangādara Bandāri's wife, Maloti, applied for land rights over 0.7 acre of land owned by Pejāivara Mutt, and her application was accepted. Harish Shetty, a member of the Mundabetțu guttu, explained the context of this application as follows. The maternal uncle of Ishwara Shetty, the head of the Mundabetțu guttu before Muttaya Shetty, paid Pējāvara Mutt some money and acquired rights as a landholder. However, he continued to pay a small amount of rent to the mutt. Later, the land was divided and inherited by members of the sub-matrilineal joint family (kabarụ). The 0.7 acres of land that Gangādara Bandāri's wife applied for was one of the plots that was divided and inherited at that time. This land had been gifted to Gangādara as a part of dowry by Gangādara's maternal uncle, who was also Maloti's father (i.e. Gangādara and his wife were cross cousins). This land was cultivated by a Pūjāri tenant, but Gangādara successfully applied to the land tribunal for rights to this land in his wife's name. He did so in order to determine his own rights to the land.

Case 2 Application for 'grandfather's land'

According to VRA, on 31 December 1974, Pōvappa Shetty's wife, Girija, applied for and was granted land rights of a total of 10.8 acres of land owned by the Mundabetțu guttu. These plots had been purchased by a member of the matrilineal family and inherited by Pōvappa Shetty's mother. Pōvappa applied for and acquired land rights in his wife's name in order to determine his own rights to the plots.

Case 3 Arbitrary application for 'grandfather's land' and conflict among family members

According to VRA, on 29 June 1976, a man of Mundiabețtu guttu called Bōba Shetty applied for and was granted the rights of several plots of land totalling 39.08 acres. This land was originally owned by a kabaru belonging to the Mundabețtu guttu, and there was an ongoing conflict among the family members about dividing it. Bōba applied for land rights over these plots in order to determine his rights over them in spite of the fact that he was not cultivating them. Bōba's maternal uncle belonging to the same kabarụ filed a lawsuit against Bōba's application, and the case is still in dispute in the high court.

All the above three cases involve a member of the Mundabetțu guttu using land reform to determine rights over a part of land purchased by a matrilineal family member ('grandfather's land'). However, in the VRA, we find no cases of a member of the Mundabețu guttu applying to the land tribunal for rights to a part of the traditional family land. Hence we see that it was extremely difficult for members of a kuțuma to declare individual rights over 
traditional family land, and it was easier to assert rights over 'grandfather's land' of the kabaru to which they belonged. This corresponds to what we discussed in Chapter 10: traditional family land of the whole kutuma cannot be easily divided, and family members' rights over land remain ambiguous, whereas division and inheritance of 'grandfather's land' is a comparatively smooth process because there are fewer family members who have rights to it.

As we saw in Chapter 10, the people of the Mundabețtu guttu find themselves in between customary law (katțu) and the modern judiciary system. They have to contend with the dilemma between duty towards the continuity of the kutuma and pursuit of individual rights. Land reforms posed crises for the encompassing and complex kutuma based on large family land, but they also offered opportunities for individual members of the kutuma to determine their land rights officially by applying to land tribunals. In this context, it was easier for individuals to assert their ownership rights over 'grandfather's land' since the land was purchased by comparatively recent ancestors. Such land had weaker links with the deities worshipped by the kutumas, and did not have the historical significance as a collective resource of the entire kutuma. In other words, 'grandfather's land' offered chance of a compromise between the demand to protect family land of the kutuma and the need to determine individual land rights.

Lastly, let us examine a case where a man of Muṇ̣abețtu guttu applied for rights over several plots of land including family land of the kutuma.

Case 4 Eviction of tenant by landlord, and application and determination of land rights

Banța, Mundabetțu guttu family. Household composition: Yashoda (77-year-old, female), her son, his wife and children. They own 10 acres of land matrilineally inherited by Yashoda, and total of 16 acres of land, the rights over which were acquired due to land reform. According to Yashoda, her deceased husband, Sundar Rai, was a tenant (mūla gēnii) of Pējāvara Mutt before land reform. He applied for and was granted land rights over this tenant land at the time of enactment of land reforms. A Pūjāri tenant used to work on the land matrilineally inherited by Yashoda, but Sundar evicted the tenant.

This case shows how a man, who was a landlord and at the same time a tenant of another landlord, acquired ownership rights over a vast amount of land by applying for land rights of several plots. The case, however, is related to problems over land in another household in the Mundabețtu guttu, and the situation is more complex than the above explanation given by Yashoda and her son. Devaki, an 82-year-old woman belonging to the Mundabetțu guttu as Sundar Rai did, points out that Sundar was not the mūla gẹni of Pējāvara Mutt. It was Devaki who was the mūla gēni of the mutt, and Sundar was a subtenant (ulamūlagêni) whom Devaki had employed to cultivate the land she had rented from the mutt. In 1966, Devaki registered the family land that had been divided and she had inherited, including the land of Pējāvara Mutt, but she continued to pay the mutt an annual rent of 38 rupees 88 paise 
and 17 muḍi of rice as the mūla gêni. However, at the time of enforcement of the Land Reforms (Amendment) Act in 1974, Sundar applied for rights over the mutt's land, three plots of farmland on which he worked as a tenant, and the holding of the kabaru to which he belonged. Sundar applied for land rights to the holding of kabaru, in spite of the fact that he did not cultivate that land, because otherwise the land would be matrilineally inherited by his sisters, and he wanted to establish his own rights to the land. In the case of the mutt's land, too, Sundar was not actually the mūla gēni but a subtenant, so he should not have had the right to apply for land rights. But since Sundar had the real power over the land, Devaki, the mūla gẹni, says she did not apply for land rights because she wanted to avoid trouble. As a result, Sundar acquired rights over several plots of land.

\section{Tenants and land reforms in Perar}

Until now, we have examined the effects of land reform in Perar from the viewpoint of landlord households. So our next question is, how did tenants experience land reform at the time of enforcement of the Land Reforms (Amendment) Act?

Forty households, that is to say $58.8 \%$ of the 68 tenant households I surveyed, acquired land due to land reform. The 40 households acquired a total of 122.83 acres of land, and the average area acquired per household is 3.07 acres. These figures may suggest that many tenants successfully acquired land due to land reform. However, the processes of their acquisition were by no means easy. Many tenant households experienced conflict with their landlords and competition with other tenants. Many acquired land after prolonged court cases. Moreover, 28 households, approximately $41.2 \%$ of the tenant households surveyed, have not acquired land due to land reform. Let us examine the experiences of the tenant households below.

Case 1 Conflict with the landlord over application of land rights

Household composition: Kunnyanna (Banța, 78-year-old, male), his wife, daughter and her children. Kunnyanna's family was a tenant of 3 acres of land from his maternal grandmother's generation. There was a dispute with the landlord over application of land rights around 1974. Kunnyanna demanded that the landlord submit the contract between the landlord and the tenant called 'gēni sheet', but the landlord refused. Since Kunnyanna had not paid any land tax, he did not have any other documents to certify his case, but his application was approved by the land tribunal and he was able to acquire the land.

Case 2 False declaration by the landlord

Household composition: Lila (Banta, 70-year-old, female), her son and his wife. Lila's deceased husband and his father were tenants of land (3.75 acres) of a landlord. When the Land Reforms (Amendment) Act was enforced in 1974, the landlord made a false declaration to the land tribunal, stating, 'All my land is forest so I have no tenants. I only employ day labourers'. 
Since Lila's husband and his father were uneducated, they did not know that they were deceived by the landlord. But, later they received help from their brothers to apply for land rights with success.

Case 3 Court cases with the landlord over land rights

Household composition: Lakshmi (Püjāri, 55-year-old, female) and her children. Lakshmi's late husband and his father were tenants of an absentee landlord residing in Mangaluru city after 1964. They applied for land rights in 1974, and acquired rights in 1975. However, the landlord objected to this and asserted his own rights, leading to a court case. But Lakshmi's husband won the case in 1998.

Case 4 Competition with other tenants

Household composition: Muthu (Pūjāri, 70-year-old, female), her son, his wife and children. Muthu and her husband were tenants of a Mundabettu guttu landlord before 1974. But in 1974, their Pūjāri neighbour suddenly became the tenant, and Muthu and her husband were evicted. The Pūjāri man, who became the new tenant, acquired rights to the land due to land reform.

Case 5 Landlord's plotting

Household composition: Shina (Püjāri, 50-year-old, male), his elder sister, his wife and sons. Shina's father was a tenant of a Muslim landlord. Shina's family lived on the landlord's holding, but in 1972 just before the enforcement of the Land Reforms (Amendment) Act, a Banța man, who was also a tenant, bought the land from the landlord. The landlord gave Shina's family a mere 12 cents of land and evicted them. According to Shina, the landlord had predicted the enforcement of the Act, and sold the land before Shina's family applied for land rights.

Case 6 Court cases with other tenants

Household composition: Amma (Kudubi, 80-year-old, female), Amma's son, his wife and children. Amma's family was a tenant of a Mundabetțu guttu landlord from her paternal great grandfather's generation. At the time of enforcement of the Land Reforms (Amendment) Act, there was a dispute over land rights between Amma's father and a Banța man, who was also a tenant. They fought for land rights in court for five years having applied for the rights in 1974. Amma's father won the case, and paid 7,500 rupees, the assessed cost of land, through a government bank.

Case 7 Landlord's plotting and selling of land

Household composition: Koragu (Pūjāri, 66-year-old, male), his wife, daughter, her husband and children. Before land reform, Koragu and his wife were tenants of land yielding 2 mudi. At the time of enforcement of land reform, the landlord drew up a certificate saying, 'This land belongs to the landlord' and made Koragu put his thumbprint on the document. Since Koragu was uneducated, he put his thumbprint on the document without knowing what it was, and as a result could not apply for land rights. The landlord later sold the land, and Koragu's family acquired only 10 cents of land from the Pūjāri man who had bought the land. When I asked, 'Why were you unable to acquire land during land reform?' Koragu seemed unwilling 
to tell me the reasons at first. His wife and daughters each began to tell me, 'Father was uneducated, so he was deceived by the landlord'. The angry and resentful tone of the wife and daughters, and Koragu's regretful demeanour left lasting impressions on me.

As we have seen so far, disputes over land rights between landlords and tenants, or between tenants who cultivated the land of the same landlord, were not uncommon at the time of implementation of the Land Reforms (Amendment) Act. From the viewpoint of landlords, protecting the land under their control meant not only preserving their own rights but also safeguarding the rights of the entire kuțuma to that particular land. At the same time, land reform provided an opportunity for them to determine land rights, which had been hitherto ambiguous, by officially applying for their own rights over parts of the family land. For the tenants, however, applying for land rights over tenant land was not easy since it involved a variety of risks, such as disputes with landlords, competition with other tenants, and even eviction.

\section{Fear of the būtas' curse over transfer of land rights}

How were the bütas as 'owners of land' involved in the negotiations over land rights between landlords and tenants, and transfer of land rights due to land reform? Let us examine this in the cases below.

Case 1 'Būta's curse' in a conflict between the landlord and the tenant

Banța, Alake guttu family. Household composition: Bāläkrishna (36-yearold, male), his wife and children. Bālākrishna is currently the priest (mukkāldi) of one of the main deities in Perar, Balavāṇti. This household owns 5 acres of matrilineally inherited farmland and forest. Before land reform, Bālākrishna's maternal uncle employed a Pūjāri family as tenants to cultivate 3 acres of farmland. At the time of land reform, the maternal uncle and the tenant family fought over land rights of the tenant farmland. During this conflict, the Pūjāri family members became mentally ill one after another. This was interpreted as a curse of the būta worshipped by Alake guttu not only by Bālākrishna's maternal uncle but also by the Pūjāri family. As a result, the Pūjariri family gave up the application for land rights fearing the būta's curse. They acquired only 16 cents of homestead land. In 2006, Bālākrishna paid them some money and evicted them, regaining the 16 cents of land.

Case 2 Conflict within the family over land acquired due to land reform and būta ritual

Household composition: Kōsa (Püjäri, 47-year-old, male), his wife and children. Kōsa's maternal grandfather was a tenant of a Munịabețu guttu landlord before land reform. The land acquired by the grandfather due to the land reform of 1974 was later passed on to Kōsa's mother's elder brother (MB) and then to his son (MBS). The land was not distributed to Kōsa's mother and her sisters, who only received homestead land of 11 cents each in its place. Kōsa is critical of the fact that the land was passed on from his maternal uncle to his son, leaving out his mother, who was supposed to be 
given the land according to the tradition of matrilineal inheritance among the Pūjāri. Kōsa, however, has given up taking the case to court because if he were to fight in court with his maternal uncle over land rights, the ritual of 'land būta (jāgeda daiva)' worshipped on the land would have to be interrupted, which could lead to the büta's curse.

Case 3 Transfer of land rights and rituals due to land reform

Household composition: Mōnappa (Pūjāri, 60-year-old, male), his mother, and his wife. Mōnappa's family has the role of decorating the wooden horse of Balavāṇdi with flowers and pulling the reins in the yearly ritual of the village būta shrine. The family is also the 15th guttu in Perar, and worships the būta, Kaḍalụta Panjjūrli, who is said to be a vassal of Balavāṇḍi. Mōnappa’s father and grandfather were tenants of a Munḍabetțu guttu landlord from around 1948. When his father and grandfather were tenants, the Mundabetțu guttu organised a ritual for Kaḍaluta Panjjūrli once in every four years, and other daily rituals were performed by Mōnappa's family. Mōnappa's father applied for land rights in 1974, and acquired the land in 1979. Since then, Mōnappa's family performs rituals every year for the būta after obtaining the būta's permission through oracles.

Case 4 Tenants of land in the shrine's name

Household composition: Harish (Moyli, 38-year-old, male), his wife and children. Harish's family performs the role of carrying Pilicāmuṇụi's mask in the yearly ritual of the village būta shrine and watching over the ritual items worshipped on the altar of the shrine during the festival. Harish's father was originally a domestic labourer in a Kuḍubi landlord's house, but was lent 1 mudi of land in 1958 for performing ritual duties at the shrine from Pōvappa Chowta, who was the gaḍipatinārụ at the time. When land reform was enacted in 1974, Harish's father applied for land rights of farmland on which he worked as a tenant, but did not apply for land rights over land on loan from the gaḍipatinārụ because it was 'daiva's land (daivada jāgụ)'. Hence this land is still registered in the name of the shrine.

In Cases 1 and 2 above, we see how fear of the curse of the buta worshipped on the land prevents escalation of conflict when disputes and tensions arise between landlords and tenants, or between relatives. In Case 1, the büta's curse leads to continuance of landlord's rights and interests by making the tenant family give up applying for land rights. In Case 2, the fear of büta's curse prevents the surfacing of conflict of interests among relatives over inheritance of land acquired through land reform. In this way, it seems that the presence of deities worshipped on particular land suppresses conflict over the land to a certain extent, and contributes in preserving the existing land rights as a result.

In actual fact, however, the landlords also fear the deities' curse because if būta rituals are discontinued due to an inappropriate land transfer, the deitie's curse will fall not only upon the person who receive the land but also upon the family of the original landholder. Hence, we should not overlook the fact that landlords hold on to land linked with bütas not only because they want to 
protect their interests but also because they are obeying the orders of the deities who demand the maintenance of ties between families, land, and deities. This can be seen in the resistance movements of landlords against pressures of land acquisition by large-scale developers in the following chapter.

In Case 3, we see how the rights for worshipping the land būta were handed over from the landlord family to the tenant family when land rights were transferred from the landlord to tenant. Case 4 shows how the tenant of the land belonging to the village büta shrine did not apply for land rights because it was considered to be 'daiva's land'. The Moyli tenant gave up applying for rights because he perceived that only the trustee of the shrine, the Mundịabețtu guttu, could have rights to 'daiva's land'. 15

These cases illustrate the villagers' notion that even though the registered name of the land may have changed outwardly due to land reform, the ultimate 'owner' of the land is the deity worshipped on that land and thus the holder/manager of the land is responsible for the büta rituals. Equally, it is thought that even though a person may be recognised as the 'land owner' in administrative terms, it would be difficult for him/her to have a good long-term relationship with the land and its deity without carrying out the rituals properly. For a person to make use of a particular plot of land means creating an intimate relationship with the deity linked to the land and with the realm of the wild. Hence, a person must accept the rights and responsibilities (adikāra) towards the deity before exercising rights over land. As we will see below, this logic applies not only to būtas linked to particular plots of land, but also to Nāga who is said to be the earth goddess.

As I have already mentioned, when the Land Reforms (Amendment) Act was enforced in 1974, people who lived on landlords' land as domestic labourers lost their homes and moved to small plots provided by the government. These plots were generally referred to as 'five cents' according to the area of each plot of land per house. Most of these plots were located in the dry hilly areas that were left unused. Such deserted dry areas were called kumki and the landlords' houses nearby had customary usufruct over them. ${ }^{16}$ After the late 1970s, people who had moved to the plots of 5 cents began to participate in the rituals of the Nāga shrine worshipped by the Mundabețtu guttu who lived nearby. This was because although the people had purchased the plots from the government, the true owner of the land was considered to be the neighbouring guttu and not the government. Moreover, the ultimate 'owner' of the land was thought to be the deity whose shrine was located there. The people came to worship the Nāga shrine so that they could form and maintain an appropriate relationship with the 'owner' of the land where they had come to live.

\section{Duties to the kutuma and pursuit of individual rights}

By focusing on the period just before and after the Land Reforms (Amendment) Act of 1974, I have discussed concrete examples of the ways in people negotiated over land rights. From observations in this chapter, we see that 
land transfers from landlords to tenants were not extensive in Perar, and as a result the existing system of land tenure was maintained on the whole, just as we saw in Chapter 9 when we examined the analyses of politico-economists on land reform in Karnataka (e.g. Thimmaiah \& Aziz 1983; Pani 1984).

As we have seen in this chapter, administrative land reform not only interfered in the traditional land system in village society but also intervened and enforced changes in people's relationships with their families, neighbours, farmland, and deities. The people reassembled various social relationships, including those within the kutuma, and those between landlords and tenants, to deal with the demands of the modern law and institutional changes.

Higher-ranked guttus, such as the Mundabețtu guttu, were faced with conflict between the demands of maintaining family land and establishing individual rights, which were not easily compatible. Land reform brought about a crisis for the inclusive and complex nature of the kutuma based on large joint land holdings, and at the same time, presented opportunities for individuals belonging to the kutuma to officially determine their own land rights. They protected the rights of the kutuma as a whole by preventing parts of the family land they managed from falling into the hands of tenants. At the same time, they tried to acquire land rights as individuals by applying for rights over 'grandfather's land' of the kabarụ to which they belonged.

The guttu people thus viewed land reform that encouraged large-scale reorganisation of relationship between farmers and land in terms of crisis, and took pains to preserve the traditional land tenure system that was intimately connected to kutuma and deities. At the same time, however, they also saw land reform as a chance, and contrived to establish their individual rights without disturbing the welfare of the kutuma as a whole. This was by no means an easy task, since it required negotiations and compromises with various others, such as family members, tenants, and officials in the land tribunals, as well as the deities that exercised agency through curses and oracles. It was a process in which people, who were linked to the realm of the wild and had adikāra to the deities, reassembled new relationships with land and nature. This process involved a reimagining of their relationships under conditions where the meaning of 'land' was transformed under the governance and control of the modern judiciary system.

In the meanwhile, land reform gave tenants the opportunity to gain rights over land to which they were closely connected through their daily farm labour. However, for them, applying for land rights was a difficult task with multiple risks, including harassment from landlords, competition with other tenants, and eviction. What the tenants feared most was incurring the curse of the deities, the 'owners of land', by obstructing the relationship between the landlords' families, land, and the bütas.

What was seemed to be a straightforward transfer of rights of land ownership from landlords to tenants under the modern judiciary system was in fact a matter of much greater significance for the people, whose lives were based on concrete relationships with land and nature. From their point of view, it 
was a matter of wagering the chances of maintaining the life-sustaining relationship between humans and the realm of the wild mediated by butta rituals. Hence, tenants relinquished the opportunity of applying for land rights at times in fear of the deities' curse, or entrusted the deities with the decision of whether or not they were fit to be granted adikara to the land and deities.

The people of Perar tried to deal with the modern judicial system, which defined and demanded appropriate legal relationship between persons and land, by registering the names of land owners, dividing the inheritance of parts of family land, and applying for registration at land tribunals. At the same time, they sought for various ways to preserve the fundamental connection with fields, forests, hills, and deities, maintained and inherited by kuṭumas and brought about through ritual practices. The people attempted to reassemble relationships between others in accordance with the demands of modern law, as well as continue to fulfil their rights and responsibilities towards the deities. Such endeavours and practices fraught with conflict enabled them to sustain the circulation of wild śakti and continue to form transactional networks between humans, deities, and the realm of the wild, in spite of being governed and controlled by the modern legal system.

The modern judiciary system brought about crises for traditional matriliny and land tenure system by interfering with them and demanding reform in accordance with the law. At the same time, however, through dealing with such crises, the people came to reflect upon and clearly envisage what aspects of the kuțuma and their relationship to land should be preserved, and reassembled these aspects in relation to the modern legal system. We should note, however, that the people were able to maintain and renew their fundamental connection to the deities and the realm of the wild even after land reform. This suggests that though the reforms promoted, to some extent, the fragmentation of kutuma and redistribution of land, they did not overturn the commonly held belief of land being the basis of farmers' lives. As we will see in the next chapter, however, the people living in this region confronted a new crisis after the 2000 s which was to fundamentally overturn such a supposition. I refer to the large-scale development project of the Mangaluru Special Economic Zone.

\section{Notes}

1 The two kinds of gēṇi okkelụ, mūla gēṇi and cāla gēṇi, are generally referred to as gēni. Kāli okkelụ, who live and work on the landlords' land, are commonly called okkelụ. I refer to mūla gēṇi and cāla gēṇi as 'tenant', and kāli okkelụ as 'domestic labourer'. For accounts on mūla gēṇi and cāla gēṇi, see Sturrock (1894, pp. 130-131), Abhishankar (1973, p. 432), Maclean (1989[1885], p. 64), and Bhat (1998, pp. 86-89).

2 Mūla gēṇi who have secure land rights can be seen as a 'minor landholder' rather than a 'tenant'. In colonial South Kanara, tax levied on mūla gēni's farmland was paid either by the mūla gēṇi or the landlord (Abhishankar 1973, p. 434; Maclean 1989 [1885], p. 64). According to the interviews I conducted in Perar, the landlord paid tax through the patterụ for both mūla gēṇi and cāla gēṇi. 
3 Cāla gēni were sometimes subtenants of mūla gēni. In Mudu Perar, there are cases of Banța landlord households being the mūla gẹni of other more powerful Bantas and mutts outside the village. In the household survey conducted among 227 households in Mudu Perar, out of the 111 households who used to be landlords or tenants, only three households replied that they were mūla gēni before enforcement of the Land Reforms (Amendment) Act of 1974. Out of these three households, two households were Banțas (out of which one was a landlord household) and the other one was Kudubi.

4 Apart from rice rations, they said they received no aid from landlords even for family funerals and weddings of domestic labourers.

5 I have equated the number of plots with the number of applicants. For instance, if one person has applied for two plots, the number of applicants would be two. Where I have written 'unknown' in Table 11.1 are cases where I could not read the handwritten information on the VRA.

6 Many of the tenants who applied for land belonging to the Catholic Church were Christians, and many of those who applied for land belonging to Hindu temples and mutts were Hindus.

7 All the ages of family members in the cases mentioned in this chapter are those of 2008 .

8 Includes households in which the household head was the landlord of one of the following before land reform: family land of kutuma; land purchased by a member of matrilineal family; and other purchased land, as well as households in which the household head managed a part of the family land before and after land reform. I exclude one Banta household who is currently a landlord but the information about them is unclear, and three households (two Banta households, one Catholic household) who became landlords by purchasing land after land reform. I have indicated those households which were landlords before land reform and were also tenants of other landlords at the same time as 'landlord'. Out of the landlord households, six households were tenants of other landlords before land reform, and out of these, one household was the mūla gēni of Pējāvara Mutt.

9 Include households in which the household head, or his/her parent's and grandparent's generation were tenants, and households in which the deceased husband of the female household head was a tenant.

10 Include households in which the household head, or his/her parent's and grandparent's generation were domestic labourers, and households in which the deceased husband of the female household head was a domestic labourer.

11 Land inheritance from father to child seems to correspond to the extension of the rights of the natural child due to enforcement of the Hindu Succession Act, 1956 and the Madras Aliyasantana (Mysore Amendment) Act, 1961. However, we should note that in the survey I conducted in Mudu Perar, all four households who owned land directly inherited from the father to the child involved inheritance from father to daughter. As we see in Case 5, land inherited directly from the father to the child is inherited matrilineally from the grandmother to the mother and to the daughter. From this, it is possible that women, and not men, were prioritised in cases of land inherited directly from the father to the child. That is to say, once land was inherited by a matrilineal family, it would be maintained within the same kutuma, and males would be excluded from inheritance.

12 'Household number' in Table 11.9 refers to the serial number I gave to each household at the time of the survey. As we see in the table, Households 152 and 153 belong to the same matrilineal family, as do Households 196, 197, and 198. Hence answers about holdings of Households 152 and 153 apply to one matrilineal family land, as do those of Households 196, 197, and 198. I have excluded areas that overlap in the total land area. I have calculated the average by dividing the total land area by 15 households. Households 152 and 153 were landlords 
208 Social transformations, emergence of new umwelt

living in Kompadavụ, a village adjacent to Mudu Perar before land reform, but since they moved to Mudu Perar after losing land due to land reform, they differ from other households in Mudu Perar.

13 Excludes land yielding 226 muḍi, the area of which is unknown.

14 Out of these, one household employed tenants while the household head was a tenant of another landlord.

15 Even in cases other than those involving land reform, land belonging to büta shrines is generally supposed to be transferred only in the form of gifts and not sold.

16 Kumki usually refers to wasteland without permanent settlers or users. Neighbouring landlord has latent holding rights, but the government can expropriate it when need arises. In Perar, development of housing plots 5 cents in size began in the hilly regions around 1977, and migration of landless classes continues till today. 


\section{Bütas in the midst of the development project}

As seen in previous chapters, modern laws such as the Madras Aliya Santana Act in 1949 and Land Reform (Amendment) Act in 1974 have prompted people in South Kanara to transform customary systems of kinship and land tenure by partially rearranging or replacing them with those defined by modern law. However, these customary systems, which are deeply rooted in land and nature and are based on transactions with deities, have not been totally destroyed by the new laws and policies. For instance, even though the transfer of land from landlords to tenants was accomplished to some extent through land reforms, most of the plots of land previously owned by the Banta landlords have been maintained under the co-ownership vested in the members of kuțumas. In most cases, the worship of būta and Nāga related to particular land has also been maintained even after the landowners have changed.

Recently, however, the relations among people, land, and nature based on būta worship have been thrown into crisis by a massive development project in the area. Executing modern law and policy has accomplished the partial transformation, or the legal substantialisation, of customary laws and systems by interfering in people's daily practices, and by urging them to respond reflexively to the new laws and systems. In contrast, the project examined in this chapter is one which neither requires a response from the local people nor aspires to involve itself in the villagers' daily lives, but instead aims to achieve the physical erasure of village communities. The goal of this project is to undercut the basic premise that farmers are inseparable from their land - a premise that had been guaranteed in preceding reforms - and to use the vast acquired land in an entirely new manner.

In this chapter, I will investigate this development project's effects on local communities and examine the movements that emerged in response to it, focusing on būta worship. Būta worship has evolved as people have dealt with various critical situations, such as the encroachment of the development project, their eviction from their land, and the demolishment of village communities. Indeed, continuities can be observed between the people's conflict or collaboration with the development project and those regarding būta worship; moreover, the intimate relationship between people and deities still forms the basis of their actions. 
Below, I will first provide an overview of the features of the development project and its general effects on local communities. I will then examine the antidevelopment movement which achieved the partial withdrawal of the development project, focusing especially on the relationships between landlords and former tenants. Lastly, I will examine the complicated relations among the people, deities, and land and nature that have emerged through the encroachment of the development project. In so doing, I will also look into the transformation of power relations in the local community with an emphasis on the ongoing disputes over land acquisition.

\section{The Mangalore special economic zone and the new role of būta worship}

From the winding path through the densely forested hills connecting the interior villages to the coastal towns, there suddenly appear massive steel-frame buildings. Security guards flank the gates, while high walls and barbed-wire entanglements surround the entire complex of industrial plants. Driving along the industrial area, one can observe the red exposed soil of slashed hills and forests transformed into construction sites. Trucks piled high with earth and sand come and go, while all that remains on the roadside are a few coconut trees and some deserted houses covered with dust. Where industrial plants are already in operation, massive pipelines cut across the sky, and an extended succession of cylindrical tanks, smokestacks, and metallic plants range across the vast land. Even from afar, one can see buildings rising to the sky on the hilltops and fires burning on the highest smokestacks. At night, the lights glare from the centre of the industrial area. It is difficult, however, to grasp the entire picture of the industrial area, since it extends across thousands of acres. It is like a strange megalopolis transplanted from a different world - this was my first impression of the huge industrial plants.

These industrial plants are a part of the development area called the Mangalore Special Economic Zone (MSEZ). The MSEZ has been promoted by the central and state governments, and by several multinational corporations, mostly related to the petroleum and petrochemical sectors. ${ }^{1}$ The organisation that governs the development project is called Mangalore Special Economic Zone Limited (MSEZL, hereafter also called the 'company'), founded in 2006. In general, SEZs are primarily established with the aim of attracting foreign direct investment, especially from multinational corporations (Farole 2011). As Bedi (2013, p. 38) describes, SEZs are unique enclaves with a free-market orientation, governed by legal and tax environments that transcend regular national laws. SEZs that create economic incentives different from those in the nation as a whole are touted as enabling countries to create an advanced infrastructure. In the case of SEZs in India, the private sector is enticed with offers of cheap land to develop these zones and create world-class industrial and commercial infrastructures (Levien 2011; see also Sharma 2009 and Vijayabaskar 2010). 
Similarly, by employing one person per displaced household and paying compensation, the MSEZ has created both advanced infrastructures and new economic opportunities for some of the local people. Some have moved to rehabilitation areas offered by the company and have begun to enjoy their modern facilities. Nevertheless, as we will see below, most villagers from the requisitioned areas became destitute after being expelled from their agricultural fields.

In the course of this project, several villages and numerous religious structures, including būta shrines, were destroyed, and land acquisition by MSEZL displaced numerous people. Prior to the foundation of MSEZL, in the mid-1990s, Mangalore Refinery and Petrochemicals Limited (MRPL), the industry adjoined to and closely interrelated with the MSEZ, had already acquired 1,850 acres of land and had displaced about 930 families. In the first phase of the project, MSEZL acquired another 1,800 acres in Bajpe, the village adjacent to Padu Perar, and several neighbouring villages, and displaced 1,518 families (Cook, Bhatta, \& Dinker 2013, p. 41; see also Dhakal 2009).

How have the people living in this area responded to this land acquisition? How has būta worship been transformed in the course of the development project? I will next examine the antidevelopment movements that emerged and the new role of büta worship.

\section{Büta worship as the stronghold of resistance?}

Since the 2000s, various antidevelopment movements have arisen in Mangalore against MSEZL's land acquisition, destruction of villages, and environmental contamination. At the outset, most movements warned of environmental pollution and protested the forceful land acquisition. For example, the members of a fishermen's association organised a sit-in to denounce marine pollution, and environmental nongovernmental organisations reported on the destructive impact of the MSEZ (e.g. Hosbet \& Bhatta 2003). Similarly, displaced farmers, social activists, religious leaders, and college students have organised antidevelopment rallies and demonstrations.

In addition to concerns about the environment and land acquisition, notions of 'local culture' and 'tradition' have recently become an essential part of antidevelopment discourse. As mentioned, in the course of the MSEZ project, several villages and numerous religious structures have been destroyed, and it has become impossible to continue rituals in those villages. The bütas, closely related to the local landscape and worshipped by the villagers, have been taken as a symbol of local culture as well as the basis of people's identity. In various media such as local newspapers, broadcasts, and websites, the oracles of būtas in villages acquisitioned by the company have been reported as voicing the deities' objections to the development project.

This growing public attention to buttas is mainly due to social activists, who have focused on the 'cultural issue' and its appeal to the media, for example, U. Uday, a photographer and social activist, held an exhibition of 
photographs of village life at risk of destruction. This exhibition was covered by several local newspapers and became rather high profile. Likewise, Vidya Dinker, an activist involved in leading several social movements in Mangaluru, made a documentary of the būta ritual held in a village manor house, whose members had been protesting against land acquisition. Regarding būta worship and the antidevelopment movement, Vidya said,

I think environmental pollution is a universal problem. Meanwhile, your research [on būta worship] is important because it can help us grasp the issues which often relate more deeply with local communities, and also are never recorded or discussed by NGOs. The traditional belief system can help the local people build resistance [against the exploitation of the company], and if it is taken away from them, their inner strength will be totally lost.

(Vidya Dinker, personal contact, 15 March 2012)

As reflected in this comment, most social activists advocate the 'local culture' and 'traditional belief system' of villagers and regard these as the core of the people's identity and worldview. Through this interpretation and representation by the activists and mass media, the people's everyday practice of būta worship has been transformed into an 'alternative epistemology' (Stoffle \& Arnold 2003) as well as a stronghold of resistance against the development project. At the same time, such discourse represents these villagers as the subjects of the antidevelopment movements, protesting against exploitation based on their identity as būta worshippers. Here būta worship, taken as a symbol of cultural protest, seems transformed from people's embodied practice into an icon of the antidevelopment movements.

When one examines closely people's various responses and practices regarding the development project, however, it is clear that the significance of büta worship in relation to the development project cannot be reduced to a mere icon of antidevelopment movements. As we will see, the deities who order the villagers to protect the land and shrine become a driving force for them to protest against land acquisition. The deities' oracles also have the compelling power to prohibit villagers from leaving their land. Moreover, new frictions among people regarding land acquisition and migration cause further disputes concerning the question of which deity should be worshipped by whom on the land in question. Thus, due to the deities, the situation of the people facing the development project becomes more and more complex. Below, I will investigate the emergence of antidevelopment movements in the villages adjacent to Bajpe (hereafter called 'the Bajpe area'), focusing first on a movement based in a village called Tenka Yekkar involving various actors, including high-caste landlords, former tenants, Dalit activists, and local deities, who consequently achieved the partial withdrawal of the MSEZ's second phase. 


\section{Local movements against the MSEZ}

\section{The antidevelopment movement led by a local magnate and a village deity}

Tenka Yekkar is a village adjoining the MSEZ. In 2007, the government chose the village for acquisition as part of the development project. However, after many twists and turns, the village was notified in 2010 that the land acquisition plan had been cancelled. Let us consider this very rare successful case of an antidevelopment movement, first from the viewpoint of a member of a powerful guttu family, and second from the viewpoint of a Dalit activist. $^{2}$

Kavaramane guttu, the top guttu of Tenka Yekkar, is responsible for the worship of a powerful village būta called Kodamanittāya. The family owns 150 acres of land. Before land reforms, many villagers worked on their land as tenants and agricultural labourers. Their manor house is situated amid beautiful paddy fields, and at the site, there is a magnificent treasure house for Kodamanittāya.

Nitin Hegde, the young head of Kavaramane guttu, stated that the Karnataka Industrial Areas Development Board notified him in 2007 that the government would acquire a total of 2,035 acres of land in Tenka Yekkar and three adjoining villages. Since 2005, MSEZL had started land acquisition for the first phase of the development project, and already in 2007, it began more land acquisition for the second phase. The Board initiated a survey of the village land soon afterwards.

In response to an urgent call by Nitin Hegde, more than 200 villagers in opposition to the land acquisition, including former tenants and workers of the guttu's land, gathered at the Kavaramane guttu house. Due to their protests, the survey by the Board stopped temporarily. During this time, the guttu family held an annual ritual for Kodamanittāya. In the ritual, the deity, speaking through a medium, stated its opposition to the land acquisition, saying, 'You should not undertake any more troubles. Go ahead, I will protect your land'.

Receiving this oracle, Hegde and the villagers held a meeting at a village public hall and decided to organise a committee called Krishi Bhumi Sanrakshan Samiti, or the 'Save the Cultivated Land Committee', as the foundation for protests against land acquisition. Through this committee, the guttu family, former tenants, and agricultural workers together developed a movement under the slogan of 'Protect farmland!'

This story illustrates a dimension of the antidevelopment movement from the perspective of a powerful local guttu family. From this viewpoint, the movement was successful thanks to several main factors: first, the strong leadership of the local guttu family; second, the solidarity of the villagers/ former tenants and workers, who were united under the guttu; and third, the supreme agency of the village deity which symbolised the land and nature 
to be protected and was the driving force of people's protests against land acquisition.

In this view, the movement is conceived of as organised around traditional authority, which united the villagers and ensured that the movement was effective. Solidarity among the people was only made possible by the social prestige and power of the top guttu, following traditional notions of hierarchy and religious authority in the village. As we will see, however, a different aspect of the same movement may be revealed by taking the perspective of Ragu, a Dalit activist.

\section{Protest against the company and landlords by small farmers}

Ragu was born in Tenka Yekkar in 1975. When the village was targeted by the development project, he was a member of Dalit Sangharsh Samiti, the Dalit movement in the state of Karnataka. His family had been agricultural workers for the Kavaramane guttu family before the Land Reform (Amendment) Act was legislated in 1974 and had made a living by farming a small plot of land.

According to Ragu, after being notified of the government's acquisition plans, one of the influential landlords in the village sought to facilitate land transfers and the evacuation of the villagers. Among the 447 acres of land targeted for acquisition, 130 acres was owned by a family called the Āgalu guttu. Though the Āgalu and Kavaramane guttus had originally composed a matrilineal joint family, the family split into two groups four generations ago. As already seen, according to the deity's oracle which was closely related to their land, the Kavaramane guttu decided not to hand over their land to the company. Contrary to this, the Āgalu guttu not only transferred their land to the company and received compensation, but urged other villagers to hand over their land to the company also.

Deeply concerned that the transfer of land in the village would advance quickly with the assistance of some of the guttus and villagers, Ragu and other activists began going door to door to inform villagers of the negative outcomes that would result from giving up their land. After this steady campaign, Ragu and other core members held a meeting in a public hall in Tenka Yekkar to organise a united protest movement with three other villages. More than 2,000 people, most of them poor landholders and former tenants, attended the meeting and decided to protest against the MSEZ. Next, they organised the Krishi Bhumi Sanrakshan Samiti, and Ragu became its president. Upon establishing this committee, they held a press conference and released a statement that they would firmly oppose the second phase of the MSEZ and refuse to transfer their land. They soon started to cooperate with various groups such as environmental activists, religious communities, and student associations.

As the movement became more influential, more conflicts occurred between the Samiti and the MSEZ, including both physical fights and lawsuits. 
Ragu and others asked for further support from Parliament and Legislative Assembly politicians, but few responded. Consequently, members of the Samiti, women in particular, showed their anger towards these politicians in unique ways; for example, when one of these politicians visited Bajpe, women aggregated and raised their sandals in unison to demonstrate their discontent. In January 2008, people in opposition to the land acquisition plans held a largescale demonstration attended by more than 6,000 people. On this occasion, representatives of several political parties, such as the Bahujan Samaj Party (BSP), Samajwadi Party (SP), and Communist Party of India (CPI), expressed their support for the antidevelopment movement. ${ }^{3}$ In addition, even among the Bharatiya Janata Party (BJP), some politicians conveyed their support for the movement (see The Hindu 2008). ${ }^{4}$ Due to the ceaseless effort of farmers within and beyond the Samiti, in August 2010 the government finally cancelled its land acquisition plan for the second phase of the MSEZ.

While from the perspective of the Kavaramane guttu, traditional authority and the unity of village society were most important, Ragu's story illustrates a different dimension of the antidevelopment movement. Namely, the people's movement against land acquisition did not necessarily depend on the leadership of the top guttu family. Rather, it was the protest by villagers against the large enterprise and the objections of small farmers to some landlords who promoted land transference that led to the movement's success.

For the landlords, such as the Āgalu guttu, who live in urban areas while owning many acres in a rural area, it is an attractive option to transfer the land to the company and receive compensation. Still, there are some landlords who have great affection for the land and nature and decide to protect it. Even among the landlords who hold a vast amount of land, attitudes and decisions regarding development projects are not uniform. Meanwhile, for the small farmers who have long made their living through cultivation and have no property other than land, the protection of their land is vital because it is very difficult for them to maintain their livelihoods only through the company's compensation. ${ }^{5}$

The actions of the farmer-led Samiti aimed to stop the landlord who collaborated with the company and promoted land transference. In the process, their movement gained support beyond the local community, and by linking various actors and organisations, they successfully created a groundswell of opposition to development. It is also noteworthy that Dalit activists such as Ragu played a central role in the movement. In fact, engagement in the antidevelopment movement formed a turning point in his life. Thanks to his contributions to the Samiti, in 2009 he was selected as the president of the village panchayat, which is in charge of both Tenka Yekkar and Badaga Yekkar.

As seen above, a movement that arose against land acquisition has since brought broader changes in social relations and the villagers' lives, although they had initially longed for constancy in their lives. Through this 
movement, differences between landlords' and small farmers' stances towards the development project have surfaced. The new situation also seems to upturn the existing power relations in this rural community-i.e. a movement led by small farmers, especially Dalits and women, won out over a large enterprise and allied landlords.

The above investigation reveals multiple aspects of the movement that brought about the cancellation of the second phase of the MSEZ. The movement was based on the solidarity of landlords and other villagers who were closely related to the land, nature, and deities in the area; and the deities' oracle functioned as the driving force for the people's movement. Another aspect of the movement was that it represented the objections of small farmers against the landlord who promoted land transference. Moreover, as we will see later, this movement developed in the midst of disputes and negotiations concerning a place called Kuḍubi Padavụ among various actors, including landlords, former tenants, company executives, politicians, social activists, and a religious leader.

As shown in this section, in the encroachment of the development project and the subsequent expansion of the antidevelopment movement in response, the deities' orders to protect the land, nature, and shrine have played a vital role in directing people's actions and decision-making. The deities' guidance, however, can never guarantee the success of people's movements against land acquisition. The force of the deities often binds people to their land, and conflicting divine forces move disputes in unexpected directions. Focusing on on-going disputes and movements over land acquisition in the following sections, I will further investigate the discord and turmoil that the development project has created, and how people strain to create new relationships with land, nature, and deities.

\section{Obeying the deity and protesting against land acquisition}

As seen in the last section, in 2008 in the Bajpe area, a large-scale antidevelopment movement emerged and grew. As a result, in August 2010 the chief minister of the state of Karnataka gave the order not to expropriate the land for the second phase of the MSEZ; and in July 2011, land acquisition notifications for most of the area were finally withdrawn. In reality, however, the land struggles of the villagers did not end with this order, because the land exempted from acquisition only accounted for 1,998 acres of the total 2,035 acres of the planned second-phase construction site. Construction work never stopped on the remaining 37 acres of land or on the first-phase site, which the company had already expropriated. Therefore, as we will see below, the villagers who lived on these sites have continued fighting to reclaim their land.

Focusing on the Nellidādi guttu family in Bajpe, I will examine below how the deity they worship forms the basis for their decision-making and protests against land acquisition. I will also investigate what role the deity plays in negotiation between the guttu family and the company. In the next section, I will clarify how the problem before the Nellidādi guttu has not 
simply been brought by the development project, but is also rooted in a long-term conflict between the Nellidādi and another guttu family over būta worship. In these investigations, the ambivalent attitude of the landlords towards the development project once again comes to the fore; at the same time, it becomes clear that the deity, who orders the guttu family to protect their land, ironically drives them into a difficult situation.

\section{Violent land acquisition and Jumādi's agency}

The Nellidādi guttu premises are on a hill set far back from the main road. Most of the woods around the house have already been cleared; several dump trucks come and go, raising clouds of dust. The hilltop overlooks a chemical factory owned by American capital as well as labourers' lodgings at the foot of the hill. Pointing at a rice field filled with mud, Kishore, a member of the Nellidādi guttu, said, 'That was also our field. They came with heavy machines and dumped mud onto it'. ${ }^{6}$

In the early stage of the development project, the land of the Nellidadi guttu family became the object of land acquisition as the construction site for the first phase of the MSEZ. As of 2015, despite most of their farmland having already been acquired by the company and construction work on it already underway, the family steadfastly opposes the company and seeks to protect their house and the büta shrine.

According to Lakshman Chowta, the head of the Nellidādi guttu family, the Nellidādi is one of the 16 manor houses in the village and has a history of 800 years. The family has been responsible for the rituals for a buta called Jumādi, who is worshipped by the entire village. Jumādi's shrine is on the Nellidādi guttu's premises, and water from a sacred well for the deity is believed to be holy water efficacious against snakebites.

Similar to most farmers in this area, the Nellidādi family members have made their living mainly through rice cultivation. It was not until 2005, when the company started to survey their land, that the Nellidādis noticed that a project was even going on in this area. 'At that time, we didn't know what they were going to do', said Lakshman. In 2007, the guttu family received notification from the government that 35 acres of their land was to be acquired by the company. Despite the family's protests, 3 acres of their land was forcibly acquired in 2011, and several houses, including Kishore's, were demolished. ${ }^{7}$ In May 2012, some 300 workers, including hired thugs, came to the family's land with heavy machines, dumped tons of mud onto their fields, and destroyed their farm products. Lakshman and some other family members, who tried to stop them, were injured by the thugs. One of the thugs spoke violently to Lakshman:

You got money from the government and yet you're still here. If you're not leaving, then how about we just kill you and bury you under the mud? 
Upon receiving a telephone call from Lakshman, the aforementioned social activist Vidya hurried there with a TV camera crew and captured the scene of bulldozers destroying the farmland while the women and children of the guttu family looked on, sobbing. In front of the TV camera crew, Lakshman depicted the current predicament of the historic Nellidādi guttu family as being caused by the company. Through the help of Vidya, the incident was broadcast on local TV and online and attracted popular attention. In June 2012, the family filed a case against the company with the high court of Karnataka, and this issue is still in dispute.

With the help of social activists, the Nellidādi guttu family has thus strived to protest against the company that has used violent means to acquire land. In their mass media representation, they are the victims of a cruel development project and idealised peasant-subjects protesting exploitation. The reason they accept neither evacuation nor compensation, however, is not simply their affection for the land and their dignity as farmers. The biggest factor in why they cannot leave their land is the powerful deity Jumādi. As we will see below, protests against land acquisition were actually imposed on the guttu family by the supreme order of Jumādi.

\section{The deity as the supreme commander}

This case reveals not only the physical and legal conflicts between the company and the guttu family but also their spiritual battle. As described, the Nellidādi guttu worships the powerful būta Jumādi, and just after their conflict with the company, they held a yearly ritual (nēma) for this deity. At the ritual, the deity-incarnated in a medium - gave them an oracle:

I'm not leaving here. I want this house. This is my house. Let them [the MSEZL officers] touch the threshold of my shrine; then I will show them who I am!

For the members of the Nellidādi guttu, the oracle was received as a strict order to prevent the company from invading their land. For them, not to obey the deity's order would mean to accept the danger of receiving her curse. As already seen, a village deity like Jumādi is thought to embody the realm of the wild, and thus to have power to decide the fate of the whole village. Only worshipping the village deity and receiving her blessing can promise the peace and prosperity of the guttu family and the whole village, while her anger and curse may endanger their continued existence. At odds with the mass media's image of the deity as a positive and static icon of the villagers' identity, the family's obedience to the deity is rooted in their desire for protection from her and their fear of her curse (cf. Shah 2010, p. 117).

In the case of the Nellidādi guttu's struggle against the company, Lakshman and his family members have acted as political subjects, filing a case against 
the company and using the mass media to draw public attention. At the same time, they have maintained an intimate relationship with Jumādi and have continued to obey her supreme orders. Following Jumādi's orders, they have made desperate efforts to hold onto their ancestral land and būta shrine, long after most villagers have migrated to other places. Regarding Jumādi's power against company pressure, Lakshman said:

Thanks to the daiva, we are still here. Without daiva's power, they would have demolished this house a long time ago.

(Lakshman Chowta, 1 September 2012)

As this statement shows, for them, it is by the deity's mercy that they still remain on their own land. At the same time, it should not be overlooked that the reason they cannot leave the land is because of the deity's order. Their actions and decisions concerning the land acquisition plan depend on Jumādi, who is their supreme commander.

Next, I will examine an annual ritual in the Nellidādi guttu house, in which the company officers and Jumādi incarnated in a medium interacted with each other, and the deity's oracle influenced their decision-making.

\section{Officers in ritual and Jumädi's agency}

The participants in the nēma held at the Nellidādi guttu house in 2012 were not limited to the Nellidādi family and other villagers. Interestingly, several MSEZL officers also attended the ritual with the intention of asking the deity's permission to relocate her shrine. In the ritual, the conversation between the deity and the officers went this way:

JUMĀDI: This is my land. I won't leave it.

MSEZL OFFICER: We will arrange everything for you. We will construct a new shrine for you.

JUMĀDI: You can do anything with my shrine, but will you be able to set the foundation stone of my well in another place? Can you move my well? MSEZL OFFICER: Then we will have to take this issue to the centre [central government].

JUMĀDI: I am the centre!

After this ritual, the officers discussed this issue and decided to suspend the acquisition of the Nellidādi guttu's land, including the büta shrine and its well. This case shows that the guttu's land was saved thanks to the deity's orders, even if only temporarily. As seen in this case, the agency of the buttas has had a great effect on the people involved in the conflict over the development project, even on the company's side. Before considering this point more deeply, next I will investigate the relationship between the development project, local politics in the village, and būta worship. 


\section{Conflict between guttu families and the politics of land acquisition}

It bears repeating that būta worship has often been described by the mass media and social activists as being the basis of the local people's identity and their protests against the development project. The villagers facing pressure regarding land acquisition, however, do not always share this view or share an identity based on būta worship; while būta worship has the power to bring people together, it has also caused conflicts and splits in village communities. In particular, as seen in the previous section, most landlords see an opportunity to gain large profits by transferring their land to the company, but their duty is to protect the village land, nature, and būta worship. Their ambivalent position leads to differences among landlords' attitudes and decision-making concerning the development project.

As I will examine in this section, the development project's advancement has created new disputes among the people in the Bajpe area, but an analysis of antecedent disputes at the village community level is necessary to understand the structure of these new disputes.

\section{Prelude to the division of the village: a lawsuit over the büta shrine}

As seen in the last section, the Nellidādi guttu has found itself in the predicament of having their farmland destroyed and facing continued pressure of company acquisition regarding the land that has thus far narrowly escaped destruction. Most of the villagers have already migrated to other areas, so the Nellidādi guttu house remains like a solitary island in the midst of the construction site. Why have the Nellidādi family been put in such a difficult situation despite their status and prestige in the village as a historic guttu house? To understand the reasons for this, it is necessary to consider the long-lasting dispute between the Nellidādi guttu and the first-ranked guttu in Bajpe.

There are 16 guttu houses in Bajpe, which are ordered hierarchically from the first to the sixteenth. Like in other villages in this area, the ranking of the guttu houses in Bajpe is inseparable from būta worship. The rank of each house is believed to have been decided by the deity in the mythical past. In addition, in the yearly ritual, these ranks are manifested and approved when the deity gives blessings to the head of each guttu house according to its rank. Among the several guttu houses in a given village, the head of the first-ranked guttu usually takes charge of the büta worship at the village level. In the case of Bajpe, however, the Nellidādi guttu, which is the fourth-ranked guttu, has played the central role in the worship of Jumādi. The shrine of Jumādi is on the estate of the Nellidādi guttu house, and only male members of this family are selected for the role of the gadipatinārụ.

The status of the Nellidādi guttu family based on their role in Jumādi worship became especially salient when the Sundotțu guttu, the first-ranked 
guttu in Bajpe, started to claim its own trustee rights of the Jumādi shrine. I will next examine the process of this dispute by focusing on a lawsuit between the Nellidādi guttu head Lakshman as the plaintiff and State of Karnataka, the Deputy Commissioner for Hindu Religious and Charitable Endowments, the Assistant Commissioner for Hindu Religious and Charitable Endowments, the Sundọtțu guttu head D. Rai, and seven other villagers as defendants.

First it is helpful to have a brief outline of the background of this lawsuit. According to a document submitted by D. Rai on 23 May 2001 to the Assistant Commissioner, D. Rai and other devotees of Jumādi held a meeting on 13 May and decided to found a management committee for the Jumādi shrine. Nine villagers were selected as committee members with five-year terms, while D. Rai was selected as trustee for life. According to D. Rai, Lakshman Chowta from the Nellidādi guttu was selected as one of the committee members. However, Lakshman insisted in his own letter to the Assistant Commissioner on 21 May 2001 that he had already been selected as trustee of the Jumādi shrine in a meeting held on 11 May at the Nellidādi guttu house. To look into this issue, the Assistant Commissioner sent an investigator to Bajpe to interview both parties. As a result, the Assistant Commissioner questioned the legitimacy of the meeting held at the Nellidādi guttu house and approved instead the decision of the newly established management committee led by D. Rai. The lawsuit examined below was filed as a complaint from the Nellidādi guttu regarding the Assistant Commissioner's decision.

According to the judicial record (Writ Petition No. 40504 of 2001) of the High Court of Karnataka, D. Rai and other eight members were appointed by the Assistant Commissioner as the managers of Sri Kanthanadhikari Daivasthana (i.e. the Jumādi shrine) in Bajpe on 29 September 2001. Lakshman, however, filed a case insisting that the Nellidādi guttu had always been the hereditary trustee of the shrine and thus that the Assistant Commissioner's appointments were invalid. Lakshman's advocate argued that although the Assistant Commissioner's appointment of the trustee was based on sections 39-42 of the Madras Hindu Religious and Charitable Endowments Act, 1951, these sections had been nullified by the High Court, as affirmed by the Supreme Court. Therefore, the Assistant Commissioner had no jurisdiction to appoint the trustee.

The following judgement was pronounced on this case in February 2002: the plaintiff insisted that he was the hereditary trustee of the shrine, but did not submit any documents which could prove his status. Because the plaintiff continued as a trustee based only on the wishes of the deity and astrology, he should be regarded not as the hereditary trustee but as the person appointed by the devotees of the deity. Therefore, he had no authority to take exception to the decision of the Assistant Commissioner. In addition, the appointment by the Assistant Commissioner was not based on sections 39-42 of the Madras Hindu Religious and Charitable Endowments Act. Rather, 
the Assistant Commissioner only approved the selection of the trustee by the devotees of the deity (i.e. D. Rai and other villagers). Therefore, the plaintiff's claim that the appointment by the Assistant Commissioner had been unjust was invalid. As a result, the appeal by Lakshman was dismissed.

The dispute between the Nellidādi guttu and the Sundoțtu guttu, however, was still not settled. Even after this judgement, the Nellidādi guttu continuously insisted on their rights as hereditary trustee as ordered by the deity, while the Sundoțtu guttu insisted on their rights as official trustee as authorised by the government. Regarding this, I will next examine the lawsuit (Writ Petition No. 18958 of 2007) filed by Lakshman at the High Court of Karnataka against the Deputy Commissioner for Hindu Religious and Charitable Endowments in Dakshina Kannada and D. Rai.

In 2007, Lakshman filed a case against the Deputy Commissioner's order appointing D. Rai as the trustee of the Jumādi shrine and rejecting Lakshman as the hereditary trustee. In the January 2009 judgement of the case, the judge listed the people appointed as trustees of the Jumādi shrine and pointed out that there was no document that could prove the relationship between the previous trustees and Lakshman; moreover, he emphasised that they had not been appointed as hereditary trustees. While the judge admitted that the Nellidādi guttu family had contributed to the management of the Jumādi shrine, he pointed out that the shrine (referred to in the court record as 'temple') was not a private religious institution belonging to a particular family, but a 'public temple under the control of the Muzarai Department in the State of Karnataka'. The judge thus decided that the order by the Deputy Commissioner was valid, and hence the appeal by Lakshman was dismissed again.

As seen above, through a series of disputes over the trusteeship of the Jumādi shrine, the Sundoțtiu guttu achieved legal status as the trustee, while the Nellidādi guttu, who had been the hereditary trustee appointed by the deity, was disregarded. In addition to the legal disputes, before 2010 D. Rai and other members of the Sundotttu guttu published a pamphlet on the Jumādi shrine, which contained their history of the shrine with photos of the core members of the Sundoțtu guttu as the trustees. In this pamphlet, the Nellidādi guttu house was referred to as the 'treasure house' to store the paraphernalia for the būta ritual, and there was no account of the role of the Nellidādi guttu as the main patron of the ritual. The pamphlet thus promoted the centrality of the Sundoțtu guttu in Jumādi worship, while the role of the Nellidādi guttu was intentionally marginalised.

The disputes between the two houses have influenced relationships among the villagers as well as the butta ritual in the village. For instance, although the paraphernalia kept in the Nellidādi guttu house used to be circulated among several guttu houses during the nēma, since the dispute this practice has stopped. Among the villagers, the difference of opinion between the Nellidādi side and the Sundoțțu side became obvious. The disputes over the trusteeship of the butta shrine have thus caused discord among the villagers and created a schism. 


\section{The landlord as broker for the development project}

When looking at the disputes over the Jumādi shrine, we can see a clear contrast in the arguments of the two parties. Namely, the Sundoțtu guttu planned to achieve and justify their rights in the shrine by modern and official means, such as the foundation of a management committee and the appointment of trustees by the government. Meanwhile, based on the deity's oracle and oral epics, the Nellidādi guttu has strived to keep their conventional rights and status as the main patron of the shrine. The assertion of the Nellidādi guttu based on the deity's order, however, did not lend itself well to litigation in the modern courts, and the appeals of Lakshman were dismissed twice (it is also worth noting that a similar contrast can be observed in the dispute examined in Chapter 8 between the Mundabettu guttu and the management committee).

This contrast between the approaches of the two guttus is even more obvious in their attitudes towards the development project. Near the end of the first decade of the 2000s, when the land acquisition plan was raised, D. Rai of the Sundotttu guttu came to play the role of broker, mediating between the villagers and the company. Most of the villagers, excluding the Nellidādi guttu and several other families, followed his advice and handed over their land to the company and migrated to the rehabilitation area. The Sundotțu guttu family, who worshipped a deity called Tappaidi in their house, also left their land. They brought along this deity's paraphernalia after performing a ritual to temporarily extract the deity's power (ākarșaṇe) from these items.

The situation of the higher-ranked guttu family deciding to transfer their land to the company and persuading other villagers to transfer their land is similar to the case seen in Tenka Yekkar. In Tenka Yekkar, however, the Âgalu guttu who promoted land transfer was an absentee landlord, while the Kavaramane guttu living in the village decided to protect the land based on their close relationships with the other villagers. In addition, there were some people like Ragu who could organise small farmers against land acquisition without needing to depend on the landlords. For these reasons, the villagers in Tenka Yekkar were successful in advancing the antidevelopment movement.

In Bajpe, meanwhile, in addition to the villagers being split due to the dispute between the major guttu families, land transfer here was promoted by the Sundotțu guttu, who had occupied the central position in the village as the first guttu as well as the trustee of the village büta shrine. Under these conditions, it was quite difficult for the villagers in Bajpe to organise a protest movement against land acquisition. Indeed, most villagers relinquished their land and left the village, leaving only the Nellidādi guttu and a few families behind with the Jumādi shrine.

In Bajpe, the intrusion of the development project thus revealed discord and fissures among the villagers, which had grown slowly over a long period of time. Here, Jumādi's orders to protect the land, nature, and the village 
shrine spurred the Nellidādi guttu, the de facto trustee, to protest against land acquisition and stay on their land. Meanwhile, for the Sundoțțu guttu, the development project offered them the chance to gain compensation both for their own land transfer and for their services as a broker. Moreover, it gave them the opportunity to demonstrate their status and power as the first-rank guttu family in the village.

As already seen, D. Rai and other members of the Sundotțu guttu family had taken various measures to obtain and justify trusteeship of the Jumādi shrine. Their attitude towards cooperating with the company for land acquisition, while seeking trusteeship of the village būta shrine based on land and nature, seems inconsistent. When we consider, however, that Jumādi is the village deity whose worship is closely linked to prestige, power, and honour in the village community, the Sundotțu guttu's strategy makes more sense. Through lawsuits over the trusteeship of the shrine, they were seeking authority and prestige as representatives of the village. Their goal was to acquire officially the position of magnate of the village, i.e. the top guttu and trustee of the village shrine. With this aim, they contacted the company and led negotiations regarding land acquisition and villager migration.

Unlike the Nellidādi guttu, who decided to remain in the village with Jumādi, the Sundottțu guttu decided to take responsibility for moving their deity and fellow villagers to another area. Migration is, of course, one possible option for landlords facing advancing development projects that are seeking to acquire land. Contrary to their expectations, however, this migration of people and deities is not always successful, but can cause various problems regarding their resettlement. Focusing on a place called Kuḍubi Padavụ in Permude village, I will next examine disputes caused by the migration of newcomers - along with their deities.

\section{Disputes over land, rivalries over deities}

As seen in Chapter 11, in the disputes over landownership between landlords and tenants, the deities worshipped on the land in question often contributed to maintaining the original land rights by deterring tenants, who feared the deity's curse, from applying for land transfers. Although the case examined in this section is also a dispute between a landlord family and former tenants, the structure of the dispute is more complex due to its relation to the development project. In this case in Kudubi Padavụ, the landlord family had immigrated to the area, while the tenants were the original inhabitants. As we will see, the entanglement of relations between the original inhabitants, newcomers, land, and deities created new disputes over land rights and the authority of the deities. Among them, one of the main disputes concerning būta worship became the rivalry between the royal būtas worshipped by the landlord and the lower-ranked bütas worshipped by the former tenants, and there was disagreement over where and by whom the village deity should be worshipped. 
Below, I will first briefly overview the characteristics of the lower-ranked būtas who are mainly worshipped by the former tenants and day workers in this area. These būtas are different in many ways from the rājanụ daivas or royal būtas examined in Part One. Next, focusing on Permude village, which had been partly acquired by the MSEZ, I will examine the conflict between the Banta landlords, who transferred their land to the company and migrated to Kuḍubi Padavụ, and the Kuḍubis already there.

\section{The worship of wild bütas}

As mentioned in Chapter 3, the people in South Kanara worship not only the royal bütas who occupy higher positions in the hierarchy of deities, but also lower-ranked būtas called 'kāṭu (wild, undomesticated) būta'. In Bajpe and neighbouring villages including Permude and Perar, there are numerous small shrines for these būtas. Unlike the royal bütas whose worship is organised mainly by the guttus, the worship of these lower-ranked bütas such as Kallurți, Satyadēvate, Mantradēvate, and Guliga is conducted by the head of one family. Among them, in addition to the land bütas who are inseparable from particular lands, there are bütas who are believed to 'come into (baidena)' the house for various reasons. For instance, a family might begin worshipping Mantradēvate when one of the family members experiences some misfortune and receives advice from an astrologer to worship the buta that may have caused the problem. ${ }^{8}$ These bütas occupy a more marginal position compared to the royal bütas, and they are worshipped mostly not by landlords but by former tenants and agricultural workers. I will now present some typical cases that illustrate how people start worshipping kātụ būtas. ${ }^{9}$

Case 1 Sudden possession by Mantradēvate

Kudubi, a former tenant family. Pande (31) and Vedapati (30) were married in 2006. Soon afterwards, Vedapati started suffering seizures of trembling, which was thought to be a sign of spirit possession. Once a seizure started, nobody could stop her strange behaviour such as trying to throw herself into a well or suddenly running to her mother's house. Pande first consulted with a Brahman priest at Katir Temple in Mangaluru, who advised him not to believe in evil spirits. The condition of his wife, however, was growing worse. Then suddenly a deity possessed Vedapati and requested that they conduct a ritual. This time, Pande consulted an astrologer about the problem. The astrologer told him that it was Mantradēvate who had possessed his wife, and then he performed a ritual to transfer the deity's power from Vedapati to a statue $(p \bar{a} p \varepsilon)$. After this, the couple has made daily offerings of flowers and a glass of water to the statue and has conducted a yearly ritual for Mantradēvate.

Case 2 Mantradēvate's arrival through illness

Belcade, a family of former agricultural workers. In 2001, Laita (48) became ill. When she consulted an astrologer about her illness, she was advised to worship Mantradēvate. At that time, however, she could not set up 
an altar for the deity because she was living in a rented room. Additionally, Mamata (28), the daughter of Laita, developed a gynaecological disorder after she and her mother moved to one of the 5-cent plots prepared by the government. When they consulted a priest (māni) of Mantradēvate, they were told that the deity had come from Laita's mother's house. In the ritual performed by the priest, the two women made an oath in front of a coconut, the incarnation of the deity's power, that they would worship Mantradevate if she [the deity] would cure Mamata's illness. After that, they asked a Brahman priest to perform a ritual to transfer the deity's power from the coconut to a statue, and they washed the coconut down the river.

Case 3 The spell of jāgeda daiva (land būtas)

Püjāri, a family of former agricultural workers. This family worships two land būtas, Kallurți Pañjūrli and Satyadēvate, as well as Mantradēvate. According to Sarasvati (38), the land bütas bind her family to their current residence. Once the family of her late husband had performed a ritual to move these būtas to their ancestral home, but it was not successful. Though Sarasvati bought a 5-cent plot, she is still hesitant to leave these deities behind and move to the new place, for fear of their curse.

As seen in these cases, lower-ranked bütas often have dangerous features related to curses, misfortune, and sorcery. It can also be observed that worship of these butas is not systematic and formal, but personal and informal. As seen in Chapter 6, the royal būtas also embody dangerous wild śakti, and their worship is also based on devotees' fear of the deities' curses, which are inseparable from their blessings. However, while the worship of royal bütas is the core of the local political economy, such as reinforcing land tenure and the hierarchy of houses, relations between the lower-ranked bütas and their devotees are rather more private and accidental.

Keeping the difference between royal būtas and kātụ būtas in mind, next I will examine a dispute between a landlord family and a former tenant family in Permude, a dispute caused by the development project.

\section{The immigration of a landlord family and pressure on former tenants}

The Tōdu guttu is the top manor family in Permude. According to B. Shetty, one of the family elders, the Tōdu guttu has a history of about thousand years. This family has a Hindu temple called the Sōmanāthēśvara temple and a būta shrine in which Koḍamanittāya and four other būtas are enshrined. The yearly ritual for these būtas has long been held in Permude and four adjacent villages in turn.

In 2006, when the MSEZ expanded into Permude, the estate of the Tōdu guttu also became a target of land acquisition. The family decided to hand over their land to the company and migrate with other villagers to the rehabilitation area, which was also part of Permude. Regarding this, B. Shetty proudly told me that all the temples and shrines in the village had been moved to a new place in the most respectful way, performing every necessary 
ritual process. He named the rehabilitation area 'Sri Sōmanāthādama' after the name of their temple. ${ }^{10}$

However, their new residential site, Kuḍubi Padavụ, was of course not a no-man's land, but was an area already inhabited by a local community of people called the Kudubi. According to Giriya Gauda, one of the elders of the main Kudubi family in this area, their family is composed of four branches that are traced back to four male ancestors. ${ }^{11}$ In addition to village deities including Nāgabramma and Panjūrli, they worship several būtas such as Kallurți Panjjūrli and Satyadēvate. According to him, this area was originally the property of Pējāvara Mutt, a famous Hindu mutt in Udupi, and the Kudubis were the tenants of the land. When land reform legislation was implemented in 1974, they applied for land rights and received 16 acres from the government. Since then, they have made their living by farming this land.

However, in 2008, in the middle of the night, a group of thugs hired by the company attacked their paddy fields. They dumped mud everywhere and destroyed all of the farm products. After this, the company forcefully filled in the Kudubis' fields and turned them into a new residential site. It was the Tōdu guttu family who came to this new site.

Today, Kudubi Padavụ is starkly divided into two areas: one is the socalled rehabilitation area, where new residences have been built, and the other is the colony of the original inhabitants. In the rehabilitation area, the Tōdu guttu built a magnificent shrine to Kodamanittāya. In the original colony meanwhile, one can find empty shrines from which villagers took their būta statues when they left due to company pressure. Unsurprisingly, relations between the newcomers and the original inhabitants have become very strained. A Kudubi woman told me that she had stopped going out after dark, because she came to feel that she would be putting herself in danger.

As seen above, the situation in Permude village is more complex than in the usual MSEZL land acquisition process. In this case, the guttu family who acquired compensation and left their land migrated to a new area, from which they consequently forced the original inhabitants to evacuate. When we focus on the class of these two parties, this situation can be analysed as a conflict over land rights between landlords and former tenants. Meanwhile, if we focus on büta worship, it can be analysed as a process in which the new büta shrine built by the newcomer guttu family became more and more influential in this area, while the local deities worshipped by the original inhabitants came to be marginalised. Among the deities worshipped by the Kudubis, however, there remain several powerful land būtas. As seen in the previous section, a būta deeply connected to particular land often binds the devotees to the land and demands persistent protests against land acquisition. This is also the case in Kudubi Padavụ.

In addition to the ordinal būta shrines and altars, the Kudubis worship a big stone called the 'deity's stone (büta kallu)'. The officers of the company, who promoted land acquisition in Kuḍubi Padavụ and developing the 
land as a rehabilitation area, have requested that the Kudubis take the stone away. According to Giriya Gauda, the officers offered to bear the cost of constructing a new būta shrine in another place. The Kuḍubis rejected this offer because, as Giriya said, 'The daiva is tied to this land'.

Regarding this event, Mārappa Gauḍa, a relative of Giriya, told me: 'They stole our land and destroyed our farm products, but they could not remove the deity's stone'. According to him, the officers did not have the courage to remove the stone by themselves, fearing the deity's curse, and therefore asked the Kudubis to take it away.

As seen in the previous section, while the company officers promote land acquisition and the destruction of villages and their būta shrines, on occasions such as rituals or face-to-face negotiations with villagers, they often express awe of the deities and behave like ordinary devotees. When focusing on people's relationships with deities, both the villagers and the company officers share the position of recipient of the deities' overwhelming agency.

In Permude, the lives of the Kudubis were threatened due to the migration of the landlord family and other villagers. Meanwhile, thanks to the power of the lower-ranked, wild būtas, the original inhabitants managed to keep their ties to the land. As we will see in the next section, however, the situation of Kudubi Padavụ changed when it became a centre of the antidevelopment movement that resulted in the retraction of the second phase of the MSEZ.

\section{A religious leader fasting against the development project}

As seen above, relying on the power of wild būtas, the Kuḍubis have protested against the harassment they have received from the company and the powerful guttu family. Beginning in 2008, their antidevelopment movement gradually attracted the attention of the mass media and gained support from social activists. Moreover, Kudubi Padavụ moved into the limelight when a famous guru declared his support for the Kudubis. The guru, named Vishwesha Teertha Swamiji, was born in 1931 and served as an adviser to Vishwa Hindu Parisad (VHP), also known as the World Hindu Association. He was also a religious leader of the Pejjāvara Mutt, the former landlord of Kuḍubi Padavụ.

Swamiji first became involved in the antidevelopment movement after he was eagerly approached by social activists. The activists, who assisted farmers facing eviction from their land, were searching for religious leaders who would support their movement. For them, Swamiji was a very important figure because he had great influence within the BJP, the then ruling party of the state government (see Gowda 2011; The New Indian Express 2011; Daijiworld 2014). ${ }^{12}$ Regarding this, Vidya Dinker, who has supported the antidevelopment movement in this area since 2007, told me,

He [Swamiji] has great power as one of the leaders of the VHP. We knew that the state government couldn't ignore him if he performed a fast.

(Vidya Dinker, 17 August 2015) 
Though the social activists attempted to use him strategically, soon they realised that the influence of Swamiji exceeded their expectations. He built up a strong protest movement against the development project using various means such as doing interviews with the press, talking with the then chief minister, and, above all, fasting. He not only criticised the development project in general, but also expressed his concern about the predicament of the small farmers in Kuḍubi Padavụ. He also questioned the Tōdu guttu's plan to establish their right to occupation through the use of rituals.

As mentioned, the Tōdu guttu had moved the statues of deities from their original shrine and had started to build a new shrine in Kudubi Padavụ. In May 2008, just before their migration, they performed a ritual at the original shrine in which several MSEZ officers participated. By attending the ritual organised by the guttu family, the officers intended to show the villagers the appropriateness of their land acquisition and the relocation of the shrine. This event, however, was regarded as proof of a conspiracy between the company and the guttu family who promoted land transfer, and thus fed the accusations of social activists and inhabitants of Kudubi Padavụ.

In the ensuing tense situation, the Tōdu guttu advanced the construction of the new shrine, and in April 2009, they planned to organise a grand ritual ceremony made up of punaru pratișthe (ritual of rebuilding) and brahmakal$a s ́ a$ (ritual of purification). ${ }^{13}$ These rituals would symbolise the completion of the settlement of both the guttu people and their deities on the land. As soon as he heard about this plan, Swamiji decided to launch a protest against the rituals, which were being conducted against the will of the original inhabitants. He started fasting at Pejāivara Mutt on the day before the rituals, and he continued to fast for the whole day at Permude village on the very day of the rituals. Many locals joined him to protest against the rituals and also urged the government to give the Kudubis back their land. At a press conference, Swamiji told reporters that he would not lead the agitation, but that he would be on the side of the victims. He also said he would speak to the chief minister and explain the plight of the displaced.

These efforts by Swamiji not only encouraged the Kudubis, but also led to repercussions among the members of the BJP, since they were very concerned with keeping the political support of Pējāvara Mutt. Under pressure from both inside and outside the party, in August 2010 the chief minister ordered the suspension of the planned second phase. After this order, Swamiji continued to urge the government to halt the further acquisition of land. On 12 July 2011, he declared that if the government did not immediately suspend their plan to acquire 2,035 acres of land for the site of the second phase, he would go on fasting for an indefinite period, starting the next day. After hearing this final plea from Swamiji, the chief minister finally ordered a halt to all further notices, and the expansion plan was revoked completely.

As seen above, the antidevelopment movement's success in causing the total retraction of the second phase of the MSEZ was brought about by the activity of a religious leader supported by social activists as well as by 
the expansion of small farmers' protest movements. In the entanglements of the intensions and power of various actors such as the guttu family, former tenants, company officers, social activists, religious leader, and politicians, Kuḍubi Padavụ became the crucial place for questioning the propriety of the entire development project. Ironically, however, the situation of the Kudubi people remained totally unchanged, even after the withdrawal of the land acquisition plan. This was because Kudubi Padavụ was regarded by the state government as a place where land expropriation had already been completed, and thus was excluded from any cancellation. As a result, the Kudubis could neither fulfil their long-felt wish to take their land back nor settle their dispute with the guttu family; they remained in the same predicament as before. As we will see next, in these conditions, the relations among people concerning Kuḍubi Padavụ can move in unexpected directions due to the agency of the village deity manifested through astrology.

\section{Regaining the village deity}

After migrating to Kuḍubi Padavụ, the Tōdu guttu built a new shrine on their new estate. Pilicāmuṇịi, the royal būta worshipped by the villagers, was one of the deities enshrined there. While B. Shetty, the head of the Tōdu guttu, emphasised to me that the replacement of the büta shrine had been smooth, Giriya Gauda and the priest of a Shiva temple in Permude named R. Rao told me another story about the migration of the deity. ${ }^{14}$

According to them, before the villagers were forced to leave their land, the shrine of Pilicāmuṇịi had been located at a place in Permude called Mukkodi. The shrine was worshipped as the village shrine believed to bring prosperity to villagers, and the entire village participated in the yearly ritual. When the Tōdu guttu decided to migrate from Mukkodi to Kuḍubi Padavụ, however, they regarded the shrine as their private property and took the deity's statue with them without seeking or obtaining the other villagers' agreement. After migrating, the guttu family enshrined Pilicāmuṇịi in the new shrine and then monopolised its management.

Meanwhile, in a grove near Kuḍubi Padavụ, there was a small old shrine to Bramma, Raktēśvari, and Nāga. In 2013, a mutt called Taulava, which had been managing this small shrine, organised a ritual in which a new 'fact' regarding this shrine was revealed through astrology. According to the oracle, in addition to Bramma and Rakteśvari, Pilicāmuṇ̣i had originally been enshrined there. Although some years ago Pilicāmuṇịi had left the other deities behind and moved to the shrine at Mukkodi, the deity's power still filled the old shrine. The oracle also said that, contrary to the Tōdu guttu's claim, Pilicāmuṇ̣i had not actually shifted to the new shrine at Kuḍubi Padavụ along with the guttu family, but had refused to move and so still remained at the ruin of the shrine at Mukkodi, which had already become a construction site. Receiving this oracle with astonishment, the villagers in Permude decided to refurbish the old shrine in the grove to re-enshrine Pilicāmuṇ̦i. In May 2013, the reconstruction of the old shrine 
was completed, and most of the villagers in Permude, excluding the Tōdu guttu, attended its inauguration ceremony.

This case shows the complex relations between the people, land, and deities, complicated by the migration of people and the shifting of deities. This complexity stems significantly from the protean characteristics of the butas themselves: a deity is mobile, yet it is often tied to particular land; and the power of particular deity is regarded as one and the same, yet it can be enshrined in many places.

In the case of Permude, the power of Pilicāmuṇdi that had filled the original shrine was believed to have moved to the one in Mukkodi, while also retaining a strong connection to its origins. Then its statue was again shifted by the Tōdu guttu to a new shrine in Kudubi Padavụ. From the Tōdu guttu's perspective, the deity was properly enshrined in the new shrine, and this one must be the only shrine for Pilicāmuṇdi. According to the oracle, however, the power of the deity had never moved to the new shrine, but had remained in both the shrine at Mukkodi and the old shrine in the grove. If this is true, then for the villagers, the old shrine would now be the only place for worshipping Pilicāmuṇụi, since the shrine at Mukkodi has already been ruined by the company. By participating in the refurbishing work of the old shrine, and by attending the inauguration ceremony, not only the Kudubis who had been in conflict with the Tōdu guttu, but also the other villagers expressed their support for the astrological oracle and acted on its suggestion.

This case presents an alternative to the conventional view that büta worship is a means of justifying the authority of landlords in a rural community (e.g. Gowda 2005). As this case shows, even the royal būtas, who are closely related to guttu families in a village, do not always take their side. Rather, if the guttus lose an appropriate relationship with the land and nature for which they have responsibility, they may also lose the protection and blessings of the deities. In Permude, the astrological oracle suggested that the relationship between the Tōdu guttu and the village deity had been destroyed because the guttu family had abandoned their land. Eventually, the villagers who received the oracle fell away from the guttu family.

As seen in Chapter 8, in Perar, the response of the villagers to astrological oracles brought about a new development in the dispute over the management of the village būta shrine. Similarly, in Permude, the villagers' decisions and actions based on astrological oracles, which represented the deity's agency, resulted in the isolation of the top guttu family and the recovery of the worship of the village deity for all of the ordinary villagers.

These results brought Giriya, Mārappa, and other Kuḍubis feelings of great relief and exaltation, since not only the lower-ranked buttas but also the village deity was on their side. Vidya Dinker, who had long supported the Kuḍubis, conveyed their feelings this way:

I remember when Giriya told me that Pilicāmuṇdi would come here [the old shrine in the grove]. They were all surprised and very excited ... he told me, 'We could not achieve justice in court. Though politicians always 
give us their word, they never give us justice. But now, Pilicāmuṇdi is here, and we can worship her by our hands. This is a form of justice'.

(Vidya Dinker, 14 March 2014)

As we have seen, in the wide-ranging activism against the development project, the Kudubis came to play an important role through their protests, which many regarded as a symbol of farmers' rights to their land. When the plan for the second phase of the MSEZ was withdrawn, however, their land was excluded from the revocation of land acquisition. This fact also shocked them and aroused their anger against the government.

The Kudubis have thus not only been jostled by the decisions and intentions of landlords and politicians, but have also faced difficulties in relation to modern law. As seen in previous chapters, since the colonial period, the people in South Kanara have rearranged their relations with others, land, and nature in between customary law and modern law, which are heterogeneous but overlapping. Here, while modern law has pushed people to reorganise their conventional social relations, it has also offered them a way to flee from the hardships and restrictions of customary law, such as the hierarchy and land tenure system in rural communities.

For the Kudubis, however, it was quite difficult to regain their land rights through the modern legal system because they had very limited knowledge and resources to appropriately utilise modern law. In this situation, for the Kudubis, the experience of the village deity accepting their worship, while refusing the guttu family's, was thought of as achieving justice, but in a different sense from modern politics and law. Moreover, the ordinary villagers' decision to leave the guttu family who had abandoned the land and lost the deity's mercy, and these villagers' reconstruction of the village shrine on their own, changed the conventional power relations in the village; no longer did the guttu family control the land and occupy the highest rank for büta worship.

\section{People, deities, and the realm of the wild in the development project}

In this chapter, I examined the influence of, and people's various responses to, the massive development project promoted in the Bajpe area, focusing on būta worship. As land acquisition has advanced, būta worship has taken on a new role as an icon of the antidevelopment movement. When we look closely at people's decisions and actions concerning the development project, however, the ambivalent aspects of būta worship become clear. For most villagers, their protests against land acquisition spring from the deities' commands that they protect the land, nature, and büta shrines. At the same time, as seen in the case of the Nellidādi guttu, these orders can work as a compelling force to bind the people responsible for būta worship to their land.

It is also clear that landlords and small farmers have quite different positions towards the development project. The landlords who hold vast estates often take an ambivalent position towards land acquisition, though 
in a different sense from the ambivalence of deities. First, the development project offers them a chance to gain a large amount of compensation for the transference of their land. Second, due to their status and influence in their village community, they have the opportunity to obtain even more profit as brokers who mediate between villagers and the company to promote land transfer.

The landlords are thus in a position to profit greatly from land transference at the initial stages; at the same time, they have a duty to organise būta rituals and protect the land, nature, and the whole village. Therefore, some guttus have decided not to transfer their land to the company and have instead supported protest movements against land acquisition. For instance, even when most villagers had left the village, the Nellidādi guttu family decided to stay on their land and live in the difficult conditions of a construction site.

Landlords such as Āgalu, Sunḍoțtu, and Tōdu who decided to transfer their land to the company, however, are also not totally indifferent to the dissolution of the village and discontinuance of büta worship. For instance, both the Sundottṭu and Tōdu guttus planned to take other villagers as well as deities along with them when they migrated to the rehabilitation area. This fact suggests that they did not intend to destroy the village community with the land transfers and migration, but rather planned to re-establish the same social organisation and būta worship in their new dwelling place. For them, the re-establishment of the village community would enable them to maintain their status and authority.

In reality, however, even the head of a guttu family cannot easily move the village būta, which is closely tied with the land and nature in the area and forms the basis of village social relations. Therefore, the Sundotttu guttu was obliged to leave the village deity in the original shrine, while the Tōdu guttu tried the strategy of regarding the village shrine as their private property and moved the statue enshrined within it. In both cases, village social relations, being based on büta worship, have inevitably undergone great changes.

Meanwhile, for the small farmers making their living by cultivating small plots of land, land acquisition drastically changed their way of life. Following the landlords' advice or expecting MSEZ employment, some of them left their land and migrated to the rehabilitation area. Most of them, however, have protested against land acquisition in order to protect their lives and farmlands. Supported by social activists and religious leaders, they have developed an antidevelopment movement which succeeded in linking villagers and supporters from various places. They have gradually attracted the attention of the mass media and have gained influence over company officers and politicians. Moreover, being resonant with the deities' agency expressed in oracles, their activities directed towards maintaining the ties between farmers, their land, and deities have brought about changes in the power relations in the village community. 
In the case of Permude, the Tōdu guttu regarded the development project as a chance to obtain new profits and saw the village deity as an obstacle to their migration plan, despite būta worship forming the basis for their authority in the village community. As such, by constructing a magnificent shrine and performing grand rituals, they tried to portray the change caused by migration not as a rupture of the normal relationship between the villagers and the deity, but as its renewal and evolution. Their plan, however, was disturbed by people's criticism of the construction of the new shrine, and it finally dissolved when the villagers instead followed an oracle that rejected the deity's migration and started worshipping the village deity by themselves. Meanwhile, in their struggle to protect their land and būta worship, the Kudubis brought about a change in village social relations and also created a new form of būta worship independent of the guttu family.

These cases show that the deities, even including royal būtas, do not always support the rights and authority of the higher-ranked guttus, but are above all concerned with the relationship between the realms of humans and the wild. The deities always ask the people to be appropriate for undertaking adikāra to take charge of the būta rituals; and appropriateness here entails the skill to maintain the flow of wild sakti between the realms of humans and the wild by taking care of the land and the deities' shrines.

As seen in this chapter, when the village, land, and nature are in danger of destruction and the existing relationship between people and their umwelt is unsettled, it is necessary for the people to reorganise their social relations in the realm of joga, thus preserving their relationship with the deities and the realm of the wild. Otherwise, as we will see in the next chapter, people who find themselves in a new relationship with deities in novel situations must instead inevitably transform themselves into appropriate bearers of the adikāra given by the deities.

\section{Notes}

1 MSEZL is a combination of both central and state government institutions and a private financial company. It currently consists of Oil and Natural Gas Corporation Ltd (ONGCL), the Karnataka Industrial Areas Development Board (KIADB), Infrastructure Leasing and Financial Services (IL\&FS), and the Kanara Chamber of Commerce and Industry (KCCI). The New Mangalore Port Trust (NMPT) is also an equity partner of MSEZL (Dhakal 2009, p. 3).

2 The information below is based on interviews with Nitin Hegde and his relatives on 7 September 2012 and 16 August 2015 at his house in Tenka Yekkar, as well as an interview with Ragu and other members of the Krishi Bhumi Sanrakshan Samiti on 17 March 2015 at the Yekkar village panchayat office.

3 The BSP, formed in 1984, is mainly supported by the Scheduled Castes, Scheduled Tribes, Other Backward Classes, and other religious minorities. The SP, formed in 1992, is mainly supported by Other Backward Classes. The CPI was formed in 1925, but split into the Communist Party of India-Marxist and the current CPI in 1964. 
4 The BJP is the most significant Hindu nationalist political party and was formed in 1980. Its power base is Rashtriya Swayamsevak Sangh (RSS), the Indian rightwing Hindu nationalist volunteer organisation. Along with the BJP and Vishwa Hindu Parishad (VHP), the RSS forms the Sangh Parivar, the family of Hindu nationalist organisations.

5 If a family evacuate their land, one of the family members can be employed by MSEZL, in addition to the fixed amount of compensation and a residential site which is of the size from 7 to 23.5 cents. In the early 1990s, when the MRPL first started land acquisition in this area, the amount of compensation was 50,000 rupees per acre. As of 2013, the amount has been raised to one and a half million rupees per acre. Most small farmers, however, are facing difficulty after land transference which means the loss of their permanent livelihood.

6 The information in this section, including the narratives of Kishore and Lakshman Chowta, is based on interviews with them conducted on 1 and 3 September 2012 and 7 March 2013 at their house in Bajpe.

7 This land acquisition was executed based on the Land Acquisition Act, 1894, which had been effective until a new law called the Right to Fair Compensation and Transparency in Land Acquisition, Rehabilitation and Resettlement Act, 2013, was enforced in January 2014.

8 Mantradēvate is also believed to fly into one's house through sorcery or to be brought in along with particular objects such as prasāda or accessories.

9 These cases were collected from July to August 2008 in Mudu Perar. The ages of informants in these cases are as of 2008.

10 The information is based on the interview with B. Shetty conducted on 1 September 2012.

11 The description below is based on fieldwork and interviews conducted on 9 September 2012 and 14 March 2014 at Kuḍubi Padavụ.

12 In the Karnataka Assembly election in 2008, the BJP held the state government. B. S. Yeddyurappa held the position of chief minister of the state of Karnataka until he resigned at the end of July 2011. As we will see below, the antidevelopment movement led by Swamiji developed dramatically when the BJP held power; the land acquisition plan for the second phase of the MSEZ was withdrawn just before Yeddyurappa's resignation. As political background for the success of this antidevelopment movement, it has been pointed out that Yeddyurappa had close links with the religious leaders of several mutts in Karnataka (see Gowda 2011).

13 Punarụ pratisțh is a ritual conducted for the opening of a reconstructed shrine; brahmakalaśa is a ritual for when a deity's statue is enshrined in a shrine.

14 The information below is based on interviews with Giriya Gowda, R. Rao, Vidya Dinker, and two other villagers in Permude conducted on 14 March 2014. 


\section{The new umwelt in the industrial plant}

As seen in the previous chapter, the development project that developed rapidly in the 2000s has greatly affected the lives of villagers in the Bajpe area. With its close connection to land and nature, būta worship has also entered a new phase. The deities' oracles have had ambivalent effects, strongly supporting the antidevelopment movements by ordering a 'desperate defence of land and shrines' and, at the same time, binding people to their land. It has also become clear that villagers' endeavours to maintain their intimate relationships with the land, nature, and deities have partly transformed the existing power relations in the village community.

The power of the deities, although it would seem to contradict the development project, actually has great significance for the people promoting the project; as we will examine below, būta worship is flourishing anew among the people working in the MSEZ. As already seen, the MSEZL destroyed forests and farmlands in the expropriated areas and constructed industrial plants on the bare land. The company executives often stress that they have carefully separated the industrial plants from the natural environment and that they strictly control the borders. In reality, however, the industrial plants are inseparably entangled with the nature outside the complex. ${ }^{1}$ Therefore, in the same way that the industrial plants affect their surroundings through, for instance, the effluence of waste, these plants are also affected by the land and nature comprising their environment.

Regarding this, I will investigate in this chapter the encounters between humans and deities in the industrial zone, and also the effects of būta śakti, which fills the realm of the wild and flows into the realm of humans, on the activities of the people in the MSEZ. I will first examine the background of a grand ritual organised by the company managers after a tragic accident occurred in the MSEZ. Next, I will describe the attempt of a company executive to recover the ties between humans and the land, nature, and deities in the industrial zone. I will then investigate how unexpected events in an industrial unit are often interpreted as the manifestation of a buta's agency, and also how the butta ritual works to negotiate between the contradictory forces of technology and deities. Finally, I will show the endeavours of the company executives to create a transactional network between the deities 
and industrial workers through ritual practices, and to learn to behave appropriately as devotees of the deities. Through these investigations, I will consider how the newly formed transactions between the deities and the people in the MSEZ constitute the emergence of a new umwelt.

\section{An explosion on the path of a būta}

On 26 May 2011, an explosion rocked an Indian Strategic Petroleum Reserves Limited (ISPRL) plant within the MSEZ. According to news sources, a 1.5 million metric ton underground crude oil storage facility was being constructed using the drill-and-blast method. Construction work was being undertaken by SKEC-KCT, a Korean-Indian joint venture (Shenoy 2011). The Mangalore police commissioner, S. K. Singh, reported, 'The blast occurred at the tunnelling area of the site where big machines were being operated. A part of the machinery that supplies power to the tunnelling equipment might have blasted, resulting in the mishap' (Daily News \& Analysis 2011). Three people, including one Korean engineer, died. The engineer was an employee of the Korean company SK, which had received a contract from ISPRL.

The accident attracted attention both because of its tragic consequences and because it induced the management to take spiritual measures. According to Vādirāja Bhat, a Brahman astrologer, several ISPRL officers visited him just after the accident. As per their request, he conducted an inquiry ritual and found that originally there was a shrine for Pilicāmuṇ̣i at the site. It was also revealed that the explosion inside the plant was caused by the ire of the butta at the destruction of the shrine in the course of the construction work.

Following this revelation, the managers of SK and ISPRL organised a large-scale ritual for saving lives (mrtyuñjayahōmo) inside the plant, in which Indian employees as well as Korean managers and engineers participated. They dedicated offerings to the deity and received prasāda from the Brahman priests. Afterwards, they decided to build a new shrine for Pilicāmuṇ̦i inside the plant and to worship it incessantly. ${ }^{2}$ In explaining the cause of the tragedy, Vādirāja Bhat described the spiritual landscape of the site:

There was originally rājanu daiva savāri at the site. That was a path, or route, through which the deity used to pass and roam about. They constructed a building on that route ... Properly, they should have asked an astrologer where they should, or should not, construct. Because they didn't do that, the accident happened ... they [the Korean managers] realised the importance of the ritual after losing their colleagues' lives.

(Vādirāja Bhat, 1 February 2013)

It is noteworthy that the site of the original Pilicāmuṇịi shrine is described as a 'path for the deity'. This means that it was not just a solitary religious structure for the local people's worship, but also a route through which būta śakti flowed, connecting human territories to those of the divinities. The accident 
thus occurred at an intersection, the exact point where the tunnel, through which industrial substances flow, connected to the flow of śakti. Bhat's narrative thus pointed to the overlap of the pathways for different forces and substances. Underground, the original Pilicāmuṇịi shrine and the newly built industrial infrastructure became linked to one another, with catastrophic consequences (see also Ishii 2017). The ritual conducted by Bhat was a means of negotiating these contradictory forces to avoid more unanticipated events.

As shown in this case, for most people working in the industrial zone, unanticipated accidents are often interpreted as the manifestation of the deities' agency. Facing a tragic accident or problem in industry, they strive to solve the problem not only by technical measures but also by spiritual means such as astrology and ritual. Through their efforts to uncover and respond to the deities' agency behind the matter, they consequently create new ritual practices. I will investigate below the practices of company executives who increase the fear of, and concern for, the deities inside the industrial plants.

\section{Recovering intimacy with the land and deities in the MSEZ}

I will first consider the daily practice of caring for būtas inside the MSEZ in the chemical company called CS, which was established in Mangalore in 2013. CS is a multinational company based in the USA, Belgium, China, and India. Its main product is synthetic resin. The factory's surroundings are newly developed, and several families protesting against their displacement still remain in a corner of the industrial zone. The factory is right next to the estate of the Nellidādi guttu; in fact, because of the construction of this factory, the Nellidādi guttu's farmland was destroyed.

A wall surrounds the CS premises and guards check all visitors at the main gate. Entering the office requires an electronic key. In vivid contrast to the modern appearance of the office, green paddies wave in the wind in a small nearby field. According to D. Kadri, manager of human resources and administration at CS, planting a paddy in the factory compound is part of an attempt to unite industry and agriculture. He had worked as a politician in the Congress Party, serving as the mayor of Mangaluru city in 2003, and he had acquired this position in the MSEZ after retiring from politics. According to him, he and other engineers often visit the nearby Jumādi shrine.

Daivas are like elders for us. A child goes to his parents; similarly, we visit daiva's shrine. We pray to daiva only for good things, and thus good things happen to us. Nearby, there is the Nellidādi Jumādi shrine ... We pray to her [Jumādi] daily for the safety of the industry. If an accident is about to happen, it is always suddenly avoided. So, we realized that even though there had been the chance of a calamity, it didn't happen ... We treat Jumādi as our mother. Whenever we visit her shrine and pray, a sense of responsibility - what we should and should not do - arises in us. We feel ourselves being saved by her.

(D. Kadri, 10 March 2014) 
He also explained the ritual called kesarukallu päduni (a ceremony of laying a foundation stone) conducted by the company when they built the factory and office.

We conducted a great ritual. We dug the soil, laid two stones, and placed precious stones between them. We placed five metals (pañcalōha) and nine precious gems (navaratna), and then a Brahman priest poured milk on them and conducted pūjā ... in the ritual, we prayed to nature (prakṛti) this way: 'We are going to move your stones and disturb you, so we offer these precious gems and milk to you.' Also, we prayed to all creatures there: 'Please leave this place. Now we are going to acquire the land temporarily to construct buildings.' By doing this, we apologized to nature ... when we finished the construction, we again conducted a grand ritual.

(10 March 2014)

Finally, he expressed his view about the relocation of būta shrines following the construction of the industrial plants, and about the fear of the deities' curses spreading among workers in the industrial zone.

Several rituals are needed to relocate a daiva shrine, and you should not forcefully remove it. Only after consulting with daiva through astrology and getting her agreement, can you take her to a new place. In such a case, there is no worry of a curse. If, however, we force to progress something compulsorily, it [the curse] can occur. Indeed, so many people have such experiences ... If you imagine how a problem happens, you know, the MSEZ is a very big project. People from various places come to this limited space, and we are trying to create a new world. There are various ways of thinking, and also various ways of rituals. Some people do not mind local matters ... I myself, however, strongly believe in daivas and their great power.

(10 March 2014)

These narratives vividly exemplify a widely shared mixture of fear and affection, and of devotion to both deities and nature. Indeed, most executives like D. Kadri, who strongly support and promote developmental projects, also fear the būtas dwelling in the site and long for their blessings. By making offerings, conducting rituals to the land, and asking for permission, they try to gain temporary rights and responsibilities (adikāra) for the land and nature. Here, the role of the executives corresponds to that of the gadipatinārụ, the village representative and primary caretaker of the bütas and agricultural lands. Regarding this, D. Kadri's efforts to plant paddy and other agricultural plants within the factory compound can be understood as an attempt to recover, even partially, the intimate relationship with land and nature in the inorganic industrial zone.

It is not easy, however, for the people working in the MSEZ to gain protection and blessings from the deities; rather, they often become the victims 
of deities' curses. I will next examine the case of how a mishap and unanticipated event in the industrial zone brought about awareness and fear of a būta's agency and resulted in the emergence of new ritual practices.

\section{The threatening industrial plant}

P. Naik, an MRPL executive officer, lives with his family in a residential zone called the 'colony' inside the MRPL precinct. The colony is a quiet and green residential area for white-collar employees, and it contains modern facilities such as a shopping complex, swimming pool, recreation club, public school, hospital, and bank branch. In Naik's neighbourhood, beautiful two-storey houses line both sides of well-maintained road. Though Naik seems to enjoy a comfortable life as one of the executives of a big company, in his interview with me, he expressed irritation over the corruption within the company and the stresses of daily life in the closed community. ${ }^{3}$ In addition, unlike D. Kadri, who emphasised the harmonious co-existence of industry and traditional būta worship, Naik narrated his experience of the būtas' curse in the industrial zone. According to him, numerous cobras, which are believed to embody Nāga, had been killed during the construction process of the MRPL, and this has cast a dark shadow over the lives of the people in the industrial zone.

Nāga is believed to be supreme in this area. During the construction of the industry, however, many cobras were killed ... There are suicides in the colony every year, due to the curse of Nāga. People within management also have had various problems such as trouble over money and disputes ... When I and other managers consulted an astrologer to solve these problems, he advised us to conduct a ritual for Nāga (nägamañdala). In the ritual, the person taken by Nāga [the medium possessed by the deity] told us: 'This ritual was received [by the deity]. For you, however, there is no permanent solution. You have to pray to Nāga forever'.

(P. Naik, 4 March 2012)

As shown in this narrative, the people living in the industrial community often suspect a buta's curse behind the troubles and misfortunes around them, and they attempt to solve the problem through ritual practices. The problem, however, cannot be solved completely by a single ritual, and thus they have to start worshipping the deity continuously. They become aware of the buta's agency through a difficulty in their daily life, start communicating with the deity through ritual practice, and come to worship the deity at the butta shrine. Through this process, the people involved in the industry become involved in a relationship with the deities, and they performatively create a transactional network. Those who take part in this process are not only workers from South Kanara, but also foreign engineers and company managers. Based on Naik's narrative, I will next investigate the involvement 
of foreign engineers in the ritual that developed after one accident inside the MRPL precinct.

\section{The malfunction of a machine and a ritual organised by Japanese engineers}

In the late 1990s, during the construction of the MRPL plants, numerous, but not all, religious structures were demolished. One of the structures that remain is a būta shrine called the Raktêśvari sāna (shrine). It is said that when the company was about to demolish this shrine, they received an oracle from an astrologer saying that they should not demolish it. As a result, it was saved and is now a site of worship for workers inside the plant.

According to P. Naik, a compressor broke down in 1999 at a site near the Raktéśvari shrine. Japanese engineers, who were posted at the MRPL site for technology transfer, checked the machine, which had been manufactured in Japan. Try as they might, they could not find the cause of the malfunction. They checked the machine and soil again and again, but were unable to solve the problem. Finally, they agreed to consult an astrologer. Following the oracle's prescription, the engineers performed a ritual at Katir temple near Mangaluru city. They offered a sacred tolasi tree (Ocimum sanctum) to the Raktéśvari shrine and then constructed a place of worship at the site also. After the ritual, the machine worked again. Since then, the MRPL employees offer prayers at the shrine every morning before they start working.

Similar to the aforementioned Korean managers working in the MSEZ, the Japanese engineers were involved in a transaction with the deities, which was regarded as a part of the solution for the malfunctioning machine. Consequently, the Japanese engineers played a significant role as the organisers of the ritual. At first glance, it seems strange that not only the Indian employees but also foreign engineers participated in ritual transaction with the local deities. In practice, however, it was not necessarily a matter of whether these foreigners shared a belief in the bütas with the locals. Rather, their participation in the collaborative ritual practices such as offering prayers and receiving blessings from deities was regarded as most important. Through their participation in the ritual, people of various origins performatively affirm būta śakti and position themselves as recipients of the būta's agency. ${ }^{4}$ As we will see later in more detail, through repetitive ritual practices, one can transform oneself into a person who is part of the transactional network in which both humans and deities act towards each other. Before considering this issue, however, I will next examine another case of the problematic connection of būta śakti and modern technology.

\section{The connection of a pipeline with a banyan tree}

In 1999, an incident occurred when the MRPL workers and engineers, including P. Naik, were constructing a crude oil pipeline. When they began 
construction at the 'lower plateau' site, where the Rakteśvari shrine is located, they found a large banyan tree along the planned route.

There were the shrine and a banyan tree at the site. The workers said that the banyan tree that stood in the pipeline's route had caused strange things around the lower plateau ... The excavator we used for levelling hit one spot of the tree, and the machine malfunctioned. Also, when a contractor was operating the tipcart, its tires started puncturing, tup tup - tup. Then, a Muslim fellow came and said, 'I'll take care of it.' At the moment he started the machine, it completely broke down. We loaded it onto a truck and took it away ... Finally, we changed the pipeline alignment. While the old alignment remains, nobody touches it.

(P. Naik, 4 March 2012)

In Naik's description, a banyan tree, generally worshipped and feared as a sacred plant, is a focal point of the encounter or interference between būta śakti and the new industrial infrastructure. To avoid the dangerous effects of büta śakti and keep the pipeline safe, people tried to cope with the way in which the roots of the banyan tree interfered with the route of the pipeline. Yet they could not technically control the flow of sakti through the tree into the construction site, not least because it was invisible and unmeasurable. Accordingly, they were obliged to instead modify the alignment of the new infrastructure.

This is similar to what we saw in relation to the fatal accident in the MSEZ. Similar to the banyan tree, the original Pilicāmuṇdi shrine and the newly built industrial infrastructure connected disparate underground flows. Thus, the new shrine was built as a device through which people could contact būtas and nature in order to deal with the dangerous flux. Engaged in this process, both Indians and Koreans became bearers of adikāra, caretakers of both the industrial machinery and the shrine at once. Each executive was obliged to take the role of the gadipatinārụ, who is responsible for the relations among artefacts, nature, and deities. P. Naik describes the hidden linkage of sakti and technology, and a possible solution within the industry, in the following way:

The force of the deity (daivaśakti) definitely connects to modern technology somewhere ... You should believe in these ancient deities while working in modern industry. If you don't believe, you cannot succeed. Rather, you will face more problems for which you need more explanations. In the modern style of management, if anything goes wrong, you make a committee to find out [what happened] and prevent [the problem]. The next time you will confront another problem. Again prevention, again a problem, and the cycle continues ... But then if you find a connection, it will go smoother.

(4 March 2012) 
As examined above, when encountering critical events in the industry, company managers and other workers often suspect a būta's agency as the ultimate cause. Following oracles, they not only organise a ritual to appease the deity but also construct a shrine for permanent worship. Through the repetition of the reciprocal process of presenting offerings and receiving blessings, they create, and are also involved in, a transactional network with the deities, which has long been maintained by villagers in this area (see also Ishii 2015b). Based on the exploration above, I will next elaborate the relation between būta worship and people's practices in industry.

\section{Undertaking adikāra in industry}

As already seen, the MSEZ is an enclave with a free-market orientation governed by legal and tax environments that transcend regular national laws. By inviting multinational companies, building infrastructure, and constructing a modern residential area, the MSEZ forms a unique community totally different from the surrounding villages. At the same time, būta worship still maintains great significance inside the industrial zone. For instance, the deity Jumādi worshipped in Bajpe interfered in the negotiation between the Nellidādi guttu and company officers, and due to the deity's superior agency, the opposing relation between the villagers and the company officers was subsumed under the relation between the supreme deity and the humans affected by her. Similarly, accidents and troubles that occurred in industry were recognised as risks that should be technically avoided, but at the same time, they were regarded as the manifestation of a buta's agency and as a spiritual threat beyond human abilities.

Here, people's fear and sense of human passivity when encountering būta śakti does not necessarily contradict their attitude of taking technical measures against problems in the industry. In the technical aspect, they are still actors who make decisions and tackle problems in a responsible way. At the same time, as shown in P. Naik's narrative, it is often imagined that the unknowable śakti in the realm of māya is behind each problem and that it creates linkages between technical and spiritual elements.

In these situations, people come to position themselves as recipients of the būta's agency, and they learn how to respond to, and act towards, the deities. Such a reciprocal relationship between humans and deities has been the core of the transactional network in village society; in a person's relationship with a deity, one is a recipient of the deity's agency, but one is also an actor who affects his/her nonhuman partner. In the ritual process, by enticing the deity to the edge of their experiential umwelt, and acting as the recipients of büta śakti, people not only relate with the deity who temporarily manifests itself, but also act towards the realm of māya beyond the edge. Through this, they transform themselves into devotees of the deities.

As seen in this chapter, through the repetition of ritual practices, the company managers interacting with the deities create a transactional 
network inside the industry, and they learn to behave appropriately as patrons of büta worship. Here, it is worth considering why it is not the ordinary workers but the managers who undertake this primary role. This is a question of where adikāra is in the relationship between humans, deities, and land and nature. As shown in the cases examined above, the company managers do not organise those grand rituals just to placate the local workers who worship bütas. ${ }^{5}$ Rather, the büta rituals should be conducted not by ordinary workers but by executives, because the latter are the representatives of the industry. As those who are responsible for the lives and safety of the workers in the industry, the executives pray to, and interact with, the deities who are the ultimate 'owners of the land' to which the executives are newly related. Moreover, in the rituals, the executives leave to the deities the judgement of whether they are suitable for undertaking adikāra as caretakers. At the same time, they substantialise their privileged position as representatives, just as the guttu people authorise their status through their relations with būtas. In other words, to be an executive is to undertake the role of the prime caretaker, as well as to accept the risk of becoming the object of the būta's curse.

As seen in Chapter 7, through mutual interaction in the village būta shrine, the head of the guttu and the incarnate deity embody the ideal behaviours of a person in relation to bütas and as a deity in relation to humans, respectively. Meanwhile, it is uncommon for the incarnate deity to appear in the new ritual in the industry; rather, a priest conducting the ritual mediates the relation between the people and the invisible deities. Moreover, neither oral epics (pāḍdana) nor customary law (kațtụ) authorises the būta worship in the industry. The būta worship in the industrial zone is thus fundamentally different from traditional būta worship; yet still, by imitating the behaviour of the gadipatināu - the traditional patron and caretaker-each executive strives to undertake the perspective of the person in relation to the deities.

Meanwhile, through their involvement in the transaction with deities, a sense of unity arises, even if only temporarily, among the participants in the ritual. Namely, the būta worship in the industry performatively creates a ritual community, by forming a transactional network which links various people such as priests, company managers, foreign engineers, and other employees with their nonhuman counterparts.

Through the reiteration of ritual practices, company executives come to behave as the bearers of adikāra for būtas, and other participants learn how to behave as members of the ritual community, or devotees of būtas. Linking various actors inside and beyond the industrial zone, and entailing the transformation of people's behaviour, the transactional network is performatively formed and activated in the MSEZ. As I will consider in the next section, this is understood as the emergence of a new umwelt interrelated with the realm of the wild, even inside the industrial zone, which seems to infinitely expand in connection with the outer world. 


\section{Towards the new umwelt}

In South Kanara, būtas, which are tied to particular lands while travelling across regions, are regarded as wild śakti itself. Through the transaction of offerings and blessings, būta worship has mediated the relationship between people and nature/deities, and has made visible the flow of śakti between the realm of humans and the realm of the wild. Considering the situation in the MSEZ, such as the eviction of villagers, the demolition of shrines and farmlands, and the collapse of village communities, this transactional network linking people to the realm of the wild has been cut in the expropriated land.

As seen in Chapter 12, however, even in critical situations, people's endeavours to maintain their ties with the land, nature, and deities have led to the reorganisation of the transactional network in various ways. In Kudubi Padavu, for instance, the movement led by villagers longing for the protection of the land and büta worship has brought about change in the power relations in the village community, and has created a new būta worship independent from the authority of the top guttu.

Meanwhile, as I examined in this chapter, the practices of the people who were newly related to the Bajpe area through their involvement in the development project also engendered change. Since most of the people involved in the industry are strangers in this area, theirs is not a project of attempting to regain an erstwhile intimate relationship with the land, nature, and deities that support their lives. Rather, they have striven to negotiate the force of technology that emerges from their activities in the industry and the wild sakti that lies under the expropriated land and often manifests itself through unanticipated events. For the people in the MSEZ, the extensive zone that consists of the industrial plants and the manmade colony is their experiential umwelt, and tragic accidents and troubles within it are perceived as the unsettling of their relation with this umwelt. Such fluctuation brings crises into their daily lives, and at the same time, it suggests new encounters with an unknown other.

The people in the industry perceive the deity's agency through unanticipated events, and they gradually learn how to interact with the extraordinary other in order to adjust their unsettled relation with the world. Through participating in rituals and acting as devotees, they create a reciprocal relationship with the deities inside the industry. For them, this process contains the transformation of their umwelt, as well as the transformation of their ways of being.

Through astrology and ritual practices following on tragic accidents, the major components of the industrial plants, such as machines, facilities, and infrastructure, are recognised as things linked to the surrounding land and nature, or the unknown realm of the wild. At the same time, the things marginalised in the industry, such as būta shrines and sacred flora, come to the surface, and thus the umwelt for the people takes on a new aspect. While the umwelt for the people is gradually transformed by their ritual practice, the new transactional 
network which links things, humans, land, and deities creates a ritual space that performatively marks off a boundary inside the industrial zone.

It helps to imagine this situation from two shifting aerial views: if we see the MSEZ as a whole as the ground, it looks as though the ritual spaces are the heterogeneous figures that appear here and there on this ground covered by artefacts. On the contrary, if we see the surrounding land and nature as the ground, the MSEZ becomes the figure, a gigantic but fragile construction, while from the depths, numerous channels connecting the surface and the realm of the wild spread like a network, wild śakti flowing through these channels and overflowing from multiple ritual spaces.

Here, the new development of the büta worship in the industrial zone cannot be understood just as the capturing and taming of a traditional ritual by the modern system. The people organising the būta ritual inside the industry do not merely aim to placate the ordinary workers and facilitate their management by using rituals. Rather, they long to acquire the practical skills to deal with the wild sakti that is under the surface and occasionally overflows into the industrial zone. For them, conducting the būta ritual is to learn the possible ways of handling or responding to divine nature, while being keenly aware of the fragility and danger of their artificial space connected to the realm of the wild. ${ }^{6}$

In these situations, by superimposing their role in the industry upon that of the gaḍipatināru in a village community, the company executives attempt to become the appropriate persons for encountering the deities. Similar to the gadipatinārụ, who cares for the village shrine and conducts būta rituals to maintain the proper relationship with the deities, the company executives prepare a suitable environment for interacting with the deities, and they take responsibility for its continual care and management. Moreover, by responding to the būtas' agency manifested in rituals, they learn how to act as the partners of deities. In other words, each executive learns a way of being as a person who is not only active but also passive in the realm of jogga, as it is connected to the unknown realm of māya.

As seen above, while being in a position that endangers the village communities and būta worship through their promotion of the development project, the people living in the industrial zone-especially the company executives - endeavour to create a new relationship with their surroundings through interaction with deities. In this sense, similar to the villagers who struggle betwixt and between modern law and būta śakti, the inhabitants in the industrial community also live pathisch lives, being both autonomous and heteronomous, in the midst of the entanglements of modern technology and wild śakti emerging in the MSEZ.

\section{Notes}

1 Regarding the connection of modern technologies with nature, see de Laet and Mol (2000), Carse (2012), Parry (2015), and Ishii (2017).

2 Interview with Vādirāja Bhat on 1 February 2013. 
3 The interview with P. Naik was conducted on 4 March 2012.

4 For more on the relation between ritual and performativity, see Ishii (2012).

5 Previous studies on rituals or exorcism in modern factories have often interpreted these rituals as a strategy by the management to placate ordinary workers (e.g. Ong 1988). Regarding this issue, see also Ishii (2017).

6 Regarding this, see Kimura (2016), who describes the conflicts and negotiations between locals in the Tohoku region of Japan, who recognise the danger of earthquakes and tsunamis and still long for an intimate relationship with sea, and the state, which aims to build a gigantic seawall. 


\section{Conclusion}

\section{Being, pathos, and the umwelt}

In this book, I have investigated the lives of people in relation to būta worship, both through their daily social relations with each other and through their relationships with the realm of the wild, which is actualised through their interactions with deities. Throughout this investigation, I have sought to answer this book's central question: how can a person create and recreate one's umwelt and one's form of life within it through one's encounters and interactions with others, including with nonhuman beings? This question entails several key ideas that are foundational to my argument: the contingency and limitedness of every being, the inconceivability of a person's life and life-world, and the phase of life itself in the depths of an individual life. Before considering these issues, I will first review the theoretical perspective presented in this book.

\section{On magical-religious practices, modernity, and beings}

As seen in Chapter 1, magical-religious practice in non-Western societies has been an important theme in anthropology, and scholars have produced various studies on them. Among these studies, those focusing on the relations between modernity and the occult in non-Western societies have been especially prevalent since the 1980s (e.g. Taussig 1980; Geschiere 1997; Comaroff \& Comaroff 1999; Masquelier 2002; see Boddy 1994). Most of these studies seem to share the idea that magical-religious practices in non-Western societies are incompatible with modern rational values and logics, and yet/therefore they function as criticisms of the systems and institutions that originated in the modern West. From this perspective, magical-religious practices such as magic, witchcraft, and spirit possession are inseparably linked with modern phenomena such as the penetration of capitalism, globalisation, and the intensification of neoliberalism. These practices are imagined both as symbolic protests against this modernity and as imitations of its power. At the same time, they are also imagined as somehow escaping the control and scrutiny of modern rational systems and discourses.

Meanwhile, proponents of ontological anthropology present an alternative perspective on magical-religious practices in non-Western societies (e.g. Viveiros 
de Castro 2003, 2011a; Henare, Holbraad \& Wastell 2007; Holbraad 2009; Pedersen 2011). These proponents first point out the necessity for anthropologists to take things in the field as they are. They emphasise the importance of people's magical-religious practices and narratives, which they believe indicate the radical alterity of others' ontological worlds. At the same time, they criticise the functionalistic view of previous studies that have analysed these phenomena as merely people's responses to, or resistance against, modernity. Rather, their aim is to describe the ontological worlds of the people in the field as they are, as radically different from the ontological world of the modern West, while maintaining these worlds as indeterminate and virtual. These ideas are resonant with the animating ideal of ontological anthropology, namely, the ontological self-determination of people in the world.

If we compare the theoretical perspectives of ontological anthropology and the antecedent studies on magical-religious phenomena in non-Western societies, we find some similarities in their arguments, though each of them certainly has a different view on these phenomena. For most of the antecedent studies, magical-religious phenomena in non-Western societies are collectively regarded as a reference point both to make suppositions about what the 'modern West' is and to illuminate its problems and faults through contrast with these phenomena. Meanwhile, in ontological anthropology, the ontological world of the people in a non-Western society is imagined as/through difference from the modern West. Their theoretical frames are dissimilar to each other in what is regarded as the basis of differentiation, whether the basis is the modern West or non-Western societies. At the same time, they are alike in that both of them link the binary of the West and the rest through their difference with each other. In addition, both of them regard the magical-religious practices in non-Western societies as incompatible with modern rationality and therefore ungraspable by modern rational thought, discourses, or systems.

The proponents of ontological anthropology, however, distinguish themselves from their antecedents by criticising the previous scholars' reductionistic analyses of magical-religious practices in non-Western societies. They refuse to interpret these phenomena only in relation to modernity, attempting instead to describe their radical alterity as it is. Taken with the accumulation and circulation of studies that take a similar theoretical stance to ontological anthropology, various effects and problems seem to have emerged. Regarding this issue, I will not repeat the critical arguments of the several anthropologists examined in Chapter 1, but will review instead just two key questions that I raised before: the question regarding the relations between modernity and people living in non-Western societies, and the question regarding the centrality of beinglexistence.

Let us consider the first question first. Proponents of ontological anthropology have described the lives of people in non-Western societies as being in unique ontological worlds, which are radically different from the Western ontological world based on modern rationality. In doing so, they have 
tended to regard magical-religious practices and narratives as indications of these societies' radical alterity. They thereby seem to preclude concrete investigation of the roles and meanings that systems and orders characteristic of the modern West might have in someone's life in a non-Western society, and how these systems and orders relate to his/her everyday activities, including magical-religious practices.

However, what most anthropologists encounter in the field today is not an ontological world that is fundamentally different from that of the modern West, but a situation in which multiple values, orders, and ways of being - with different origins, histories, and trajectories - are intertwined and affect one another, and constitute the essential part of people's lives. As seen in this book, throughout historical transitions such as colonisation and decolonisation, enactments of modern law, and shifts in policy, people in South Kanara have lived in, made use of, and even produced systems, modes of life, and social relations that exemplify values and logics with some affinity to modern rationality. At the same time, they have still lived in, used, and continuously created and recreated systems, modes of life, and social relations, such as būta worship and the kuțuma, that embody values and logics dissimilar to those of the modern West.

These multiple systems and forces also encounter each other, contending and intertwining with one another in certain spaces and phenomena, such as būta shrines, law courts, matrilineal families, agricultural fields, and industrial plants. In the midst of these entanglements, people have strived to find their particular ways of life by using or following each system and force, and also by coordinating their relationships with various others. Hence, their ways of being are limited by multiple systems and orders with diverse values, logics, histories, and directions. At the same time, possibilities open in unexpected directions through their complex relationships with others. This awareness that people's lives are always limited and contingent raises the second question regarding the centrality of being/existence.

As mentioned above, proponents of ontological anthropology have insisted that we should maintain the ontological worlds of the people in the field as indeterminate and virtual, yet still consider them as real. These proponents also propose, as key ideals of anthropology, the ontological self-determination of the people in the field and the radical essentialism of taking things (or things as concepts) in the field as they are. In these propositions and the permeation of these ideas in arguments concerning the ontological turn, an interesting effect seems to have emerged. Namely, it has become apparent that phenomena in people's narratives and practices which seem irrational and imaginary from a modern-rationalistic viewpoint become substantialised as the objective reality for them, while being virtual for $u s$ in the modern West. Here, magical-religious narratives, and the phenomena expressed therein, are given the position of ontic beings/existence that indicate as well as exemplify the radical alterity of the ontological world of the Other. 
As būtas and their śakti in South Kanara suggest, however, a magicalreligious phenomenon is not something that is assumed to exist in the same way as the presence of an ontic object. Rather, it is a mode of being that is just momentarily actualised in between not yet and no longer (see von Weizsäcker 1946, p. 11; Kimura 2000, pp. 70-73). As we have seen in this book, the life-world of the people concerning būta worship has been formed around social relationships and institutions that form the basis of the rituals, families, and village, but this life-world is also based on concrete interactions with the deities who manifest themselves through spirit possession. In this sense, the bütas are certainly real beings for them.

This does not, however, mean that the butas can exist in the same way as ontic objects. They are intangible forces that fill the unknown realm of māya, while linking to the realm of jōga, and are transitorily actualised in between these two realms. It is likely that it is precisely because these forces are so inscrutable and contingent, their forms so easily fading away (māyaka), that people created such magnificent rituals and sophisticated systems of worship to keep communicating with the būta śakti.

What we should consider further is that this inscrutability and contingency is not unique to magical-religious phenomena, but is common to any being. The forms of both human and nonhuman beings are multiply limited by various orders and forces, which they cannot foresee or determine for themselves, but at the same time, they are always open to novel transformations. Each of these forms shows a contingent mode of being that can be temporarily actualised in between not yet and no longer. When apprehend the unknowability and contingency concomitant with every being, and we try to understand people's lives in this way, it becomes necessary to consider a phase different from that of ontic being/existence. I have attempted in this book to think through how each being can be interrelated with such a phase, particularly through reference to the Gestaltkreis theory.

\section{Pathos and the umwelt}

Responding to von Uexküll's theoretical description of a mutually determined relationship between an organism and its umwelt, von Weizsäcker focused on a more unstable organism-umwelt relationship with his Gestaltkreis theory. This theory illuminates the duplexity and intertwinement of passivity and activity. It also reveals the limitedness and transformability of the life of an organism, which is indicated in the process of the life-form of an organism as a subject becoming endangered by novel events and sublated into another form. He also presented the important notion of Pathisches, contrasted with Onthishes as pure life-form that appears from time to time in its relationship with the umwelt. Pathisches was conceptualised here as the primordial relationship of an organism with the life itself in its depths.

In contrast to the ontological anthropological perspective that tends to subsume everything into the realm of being/existence, the ideas of von 
Weizsäcker suggest that one can only think of being/existence through its relationship with virtual life itself, which is never objectified. Through reference to these ideas, I have investigated in this book how people in rural South Kanara have created and recreated their forms of life and their relationships with their umwelt through their encounters and interactions with various others. Through this investigation, I have attempted to describe the lives of people under multiple limitations from different orders and forces, yet still open to the variability in their relationships with the virtual, namely, the fundamental contingency and unknowability of life, and their pathisch relationship with the realm of māya.

\section{In between virtual and actual}

The relationships between the people in rural South Kanara and the realm of the wild, relationships which form the basis of their lives, have been created and maintained by their relations with the land and nature through daily activities such as farming, hunting and gathering, and, especially, būta worship. As examined in Chapter 5, through the manifestation of būtas in the ritual and the mutual gifting of offerings and blessings between the people and the deities, the fertile and dangerous butta sakti can be actualised.

In village society, the ranks and ritual roles of families concerning the būta ritual are determined by the oral epics and customary law. At the same time, through direct interactions with the buttas who authorise these ranks and roles, the mutual rights and duties, or adikāra, of both the villagers and the deities are renewed. Moreover, through these interactions, it is confirmed that the villagers' rights and statuses are transient and depend on the approval and protection of the deities. The interactions between the villagers and the bütas in the ritual thus reveal the people's pathisch relationship with the realm of the wild, which is filled with büta śakti.

As we have seen in Chapter 6, through the mutual gifting relationship between the people and the deities, transactional networks involving various actors are created in time and space beyond that of a single būta ritual. As observed in the kambula ritual in Perar, the būta śakti performatively marks geographical and social boundaries by circulating between, while also linking, the realm of the wild and the realm of humans, transferring itself in various substance-codes such as the butta in the forest, the paddy in the fields, offerings, and prasāda. By participating in the transactional network as a dividual person who receives and absorbs the būta śakti and transfers it to others, one becomes a person in relation to a particular family and farmland and to the forest and sacred wildness.

In Chapter 7, we investigated people's interactions with būtas and their becoming as persons in the exchange of, or playing with, perspectives, focusing on the experiences of spirit mediums and the gadipatinārụ. The spirit-medium, who becomes the deity in the butta ritual, modulates his body in relation to others in the realm of joga, and learns the appropriate 
behaviour of the deity through multiple mimesis. At the same time, he receives the būta śakti in his body as a divine grace that can be abruptly brought from the realm of māya. The skill of the spirit-medium is thus the art of maintaining his reflexive perspective while transforming himself into the deity. It is also the art of letting multiple perspectives play inside his body, blending autonomy and heteronomy, or activity and passivity. Again, through their interactions with the spirit medium who manifests the butta śakti while remaining on the border of actuality and virtuality, the gadipatinārụ and other ritual participants learn the behaviours and perspectives of persons intimately related with the realm of māya.

As we saw in Part One, būta worship in South Kanara is inseparably interrelated with the customary law and social relations concerning ranks, ritual roles, matriliny, and land tenure in village society. The continuation of the buta ritual is based on the maintenance and renovation of these systems and social relations. At the same time, through their perception of buta sakti and their pathisch relationship with the realm of māya, people's social relations and forms of life in the realm of joga are formed, modulated, and transformed. Therefore, one's life-form and relationship with others in the realm of jōga, or a person's experiential umwelt, can emerge and be continuously recreated as that which is inseparable from büta śakti and the realm of māya, which is beyond the fluid verges of the realm of jōga.

At the same time, the relations among various actors in the realm of jōga are never stable. The life-forms of people and their umwelts are incessantly transformed through their encounters with novel events and actors, as we examined in Part Two.

\section{Modernity, wildness, and būta worship}

The introduction of the centralised administration of religious institutions, the modernisation of customary law, the execution of censuses and land reforms, and the advance of massive developmental projects represent the major social and institutional changes that rural societies in South Kanara have experienced since the colonial period. These changes are, in a sense, the processes through which the values and logics that comprise modernity have been realised in the lives of ordinary people.

For instance, policies such as the enforcement of modern law, the execution of censuses, and the registration of landowners enabled the state to manage and govern local communities and populations more efficiently. At the same time, by elucidating the particular ways and conditions regarding how and when the state and the courts would grant rights, these projects encouraged people to actively participate in the modern system of governance.

These social and institutional changes enabled new ideas and norms, such as legal rights and duties, management and accountability, rationalisation, and democratisation, to come to the fore in every aspect of people's daily lives, as they encountered novel agents such as government officials, judges 
in courts, land tribunals, and so forth. Moreover, recent developmental projects have led to changes in, and even the dissolution of, existing systems and relationships in rural societies; they have cut vital linkages between villagers and the land, and they have occasioned new ways of life that are not directly related to land and nature, let alone dependent on them. In Part Two, we investigated multiple aspects of people's practices and actions under these comprehensive social changes, focusing on the relationships between people, land and nature, and būtas.

As seen in Chapter 8, with the development of the centralised administration of religious institutions beginning in the nineteenth century, the village büta shrine in Perar became subject to governance and management by the state and modern law. In this process, some people involved with the būta ritual tried to expand their rights and interests by using modern law and systems. Meanwhile, the higher-ranked guttus, who had previously been in charge of shrine management based on promises with the būtas, were urged to legitimise these management rights and duties according to the logic and framework of modern law and systems. Moreover, some villagers have recently started to demand the democratisation of shrine management based on modern law. In these circumstances, people have pursued new ways and roles in relationship with others, following both the orders of the law courts that embody modern law and logics and the wishes of the bütas, who regulate people's relations under the kattụ and manifest themselves as the supreme persons in the ritual.

The disputes between the guttu family and the management committee concerning the village būta shrine in Perar provide a clear illustration both of the turmoil and conflicts among the villagers, which unfolded under multiple restrictions, and of the process of the reorganisation of their social relations. As we saw in Chapter 8 , in the practices of the people dealing with multiple forces and logics, the relations between the plaintiffs and defendants determined by the law court could be transformed into a relationship among devotees who share the adikāra towards the būtas. It was also observed that the legal disputes and negotiations among the people were often directed by the būtas' agency. After the significant struggles and efforts of the villagers who used modern law while also being directed by the būta sakti, it was finally decided that they would establish a new organisation for būta worship, one based on the katțu, deities' order, and modern law.

In South Kanara, both the land and the kuṭuma have been places in/over which the kattụ and modern law have interfered with each other, becoming intertwined and entangled. As we have seen in Chapter 10, the stipulation and legalisation of matriliny in South Kanara, which developed from the colonial period to the 1960s, urged the guttus in rural areas to reorganise their relations with the land and kuțuma. These changes initiated a process in which the kutuma, which had been a part of the transactional network of people, land and nature, and deities as a dividual person, was redefined as an 
'indivisible community of property' and cut off from the transactional network. Moreover, this was a process that led to the dissolution of the kutuma and the dispersion of family land by defining the subject with the right to the kutuma's property as an individual.

For a guttu family who had managed vast lands based on the kutuma, to cope with these demands from modern law meant to reorganise and redefine the kutuma, which had originally been a complex community related to the guttu house, land and nature, and deities, as an economic unit constituted by several sub-groups as the aggregates of individuals. It became inevitable for the guttu family to use legal means to secure family members' rights to the kutuma land in order to maintain the resources necessary for the continuation of the kutuma and büta ritual as well, even though it entailed the risk of the family land being dispersed.

For instance, in his plan proposed around 1950, Muttaya Shetty attempted to divide and inherit the family land to each kabaru headed by a female elder. This plan was in conformity with the then law, and at the same time, it enabled the kutuma to keep the land in accordance with the customary matriliny. As this case shows, due to social and institutional changes, it became necessary for the guttu people to use modern law and systems appropriately in order to retain the kuțuma land, continue the būta ritual, and maintain their vital relationship with the realm of the wild.

However, if we look back further in history, we see that the Aliyasantana law was also formed through the encounter of modern law with the aliyasantāna kațtu practised in South Kanara and by the accumulation of precedents in the courts. Beginning with the codification of the legend of Būtara Pandya, the aḷiyasantāna kațtu transformed from the prohibition of kutumba property partitioning to the approval of individual rights to divided property. This was the process by which ordinary people came to use and obey modern law, and, at the same time, was the process that the people concerned in the judicature and lawsuits reconstructed the aliyasantāna kattụ reflexively by referring to precedents and acquiring knowledge about concrete cases in the courts.

Meanwhile, as seen in Chapter 11, the enactment of land reforms was an event that surfaced the inconsistencies and tensions within social relations based on customary law, particularly through people's encounters and negotiations with modern law and systems. It was mainly the tension between the duties of the kutuma to maintain family land and the desire of individuals to establish their own land rights. In order to resolve this tension, people tried one way after another to maintain their existing relationships with family, land, and deities, while also using modern law. When the Karnataka Land Reforms (Amendment) Act was enacted, some of the guttu members planned to establish their land rights while trying to prevent tenants from acquiring rights to parts of their kutuma land. By applying for rights to the 'grandfather's land' belonging to a kabaru, they strived to reconcile their duty to save the kutuma land with their pursuit of individual rights. 
Contrary to the expectations of the government, land reform did not just mean the transition of land rights from landowners to tenants. Rather, it became a critical event for villagers in which the continuance of the vital relationships between the people and būtas on particular lands was at stake. Therefore, some tenants withdrew their applications for land rights for fear of the būtas' curse, and others who had newly acquired land rights begged the būtas for permission and approval for undertaking the adikāra towards the land and deities.

As seen in Chapters 12 and 13, the advance of massive developmental projects was another critical event that shook the existing relationships between the people, land and nature, and deities. At the same time, it was an event that revealed in various ways how people and the realm of the wild are interrelated.

In rural societies in South Kanara, the advance of the developmental projects and land acquisition unsettled existing systems and complex relations, such as matriliny, land tenure, büta worship, and the ranks and duties of families. In the critical situation of the dissolution of a village community, some of the guttus sought new interests and endeavoured to rebuild the community in a new place, while other guttus and villagers opposed the land acquisition and strived to maintain their ties with the land and deities. In any case, people struggled to search for new ways of life and novel relationships with their umwelt.

In the Kudubi plateau in Permude village, for instance, people with various interests and backgrounds struggled for land rights and rights to the būta ritual. Through tensions and turmoil between the immigrants and original inhabitants instigated by the developmental project, villagers eventually created a new form of the būta ritual that ordinary villagers, instead of the powerful guttu family, took charge of the ritual for royal būtas in the village. This case shows the process of how encounters and interactions among various actors, including guttus, former tenants, company managers, politicians, social activists, and religious leaders, created a novel relationship of the people with their umwelt, all the while being partially directed by the būtas' agency.

In critical situations such as the intrusion of massive developmental projects, būta worship has thus played a vital role for the people in village societies to maintain and recreate their relationships with the land, nature, and the realm of the wild. As seen in Chapter 13, this is even true for the people promoting the developmental project too.

In South Kanara, land has long been the site of encounters and struggles among different orders and forces. Industrial plants, meanwhile, are places where different forces can come into contact and interfere with each other more directly, as shown in the case of a space that had originally been regarded as a pathway for būtas became a distribution channel for manmade materials and forces. Confronting various critical accidents and problems, some of the workers in the industrial plant grew aware of the büta sakti in 
the depths of the industrial zone, and they decided to conduct rituals as a measure to mediate between the būta śakti and artificial forces. Through their endeavours to interact with the surrounding land, nature, and deities in the ritual, those responsible for the management of the industrial plant came to learn the appropriate behaviours of devotees or patrons undertaking the adikāra towards the land and būtas. Likewise involved in the transfer of offerings and blessings in the büta ritual, ordinary employees also took part in the formation of the transactional network linking the industrial plant, land and nature, and the realm of the wild, and thus learned the behaviours of būta devotees.

The investigation in Chapter 13 showed that novel ritual practices, which seem to imitate village buta rituals, have developed in industrial plants. However, this does not mean that the special economic zone regulated by a modern system and technology has subsumed the wild butas and tamed their power.

As we have seen, in village society, the pathisch relationship of villagers with the realm of the wild is confirmed and revitalised through their direct interactions with butas in the ritual. Similarly, in industrial plants too, the frailty contained in manmade structures linked to nature and the realm of the wild has been brought to the fore, and the practice of the buta ritual has illuminated the contingency and uncertainty of the workers' lives there. The ritual practices of the people in the industrial plants thus suggest their awareness of the inscrutability of their life-world and the pathisch aspects of their lives and reveal part of their ventures to form and modulate their relationship with nature and wild sakti, which could variously affect the vicissitudes of their lives.

As seen in this book, for people living in rural South Kanara, the butta ritual, which is inseparably related to social relations, land and nature, and customary law and systems, has been what mediates as well as embodies the vital relationship between humans and the realm of the wild. The relationship of people with their umwelt has been formed and continuously transformed both by their daily social relations in the realm of joga and by their relationship with the realm of māya, the latter of which can be actualised through the būta ritual.

At the same time, from the colonial period onwards, rural societies in South Kanara have experienced various changes and transformations that can generically be called 'modernisation'. These processes of transformation have compelled villagers to reorganise and modify their existing social relations and modes of life by introducing novel systems and manners that exemplify different values and logics, and by making all of these function within concrete social relations. People have experienced these transformations and novel encounters with others as a crisis that has unsettled the 
existing social relations and modes of being. At the same time, they have perceived these changes as opportunities, through renegotiations and conjunctions of customary systems and social relations, for fresh relationships with others in the realm of jogga, or their everyday life-world.

Under multiple orders and forces that have directed as well as restricted their acts and practices, people have mediated their relationships with various others and re-formed their ways of life, and this has often involved dispute and conflict. Simultaneously, they have strived to maintain and recreate their vital relationship with the deities and the realm of the wild. Through their autonomous as well as heteronomous practices which contain the potential for transformation while remaining under multiple limitations, people's relationship with the realm of the wild has directed their modes of life. This is the relationship from which the life-form of each being can emerge, and it is the relationship which enables the continuance of the Lebenskreis, or circle of life, beyond individuals.

\section{Waiting for deities}

The practices of people concerning būta worship contain a seemingly contradictory duality as a fundamental entanglement. In the realm of jōga, in which various beings are intermingled and multiple orders and forces are entangled, people's activities and decision-making in forming their ways of life always occur within the duality of autonomy and heteronomy, or activity and passivity. Indeed, the life of a person who pursues a way of being in the realm of jogga, while deferring to his/her relationship with the realm of māya for how his/her life will be formed and transformed, exists in the duality of Ontisches and Pathisches from the very beginning. This suggests not only that the world around people that is never fully comprehensible contains both the phase of actuality and the phase of virtuality, but also that these phases have already been embraced in the life of each person.

In seeing the deity and being seen by her, and in transferring the büta sakti flowing in the transactional network, one becomes aware that the vague verges of the realm of joga is not the end of the world, but one that leads into the unknown realm of māya. With a sense of such a pathisch contact with sacred wildness, one may become aware of also embracing the unknown realm within oneself, which is interrelated to life itself and therefore cannot be fully understood.

If the above is the case, then the experience of the büta medium, who transforms himself into the deity by receiving the būta śakti while keeping his own perspective, does not just indicate a very special way of encountering or confronting the self and the other. Rather, it dramatically shows the very ordinary way of a person's transformation through his/her entanglement with life itself.

Through this transformation, a person gradually weakens the intensity of his/her self as subject, and, at the same time, leaves him/herself open to the 
forces coming from the realm of the virtual inside as well as outside him/ herself by disclosing the pathisch aspect in his/her body. Still, this transformation does not proceed in total disorder, but is directed by the existing form of one's self, one's relationships with intimate others, and the anticipation of the becoming through transformation. These may well be the elements that help a person to remain on the verge of the actual and the virtual without completely losing his/her reflexive self, even in the midst of a transformation filled with pathos.

The transformation from the ontisch mode to the pathisch mode of life, just in between the realms of jōga and māya, is not only experienced by a medium at the moment of spirit possession, but can be sensed in the subtler, more indeterminate attitudes or postures of ordinary people. For the last episode in this book, I will introduce one of my own small experiences that suggest the subtle, quiet transformation of a person.

On 24 February 2016, the last day of the nēma in Perar, I awoke at 1 am to wait for a car to take me to the ritual for Pilicāmuṇ̦i, which would be starting before dawn. Though it had seemed at first that nobody would take me to the shrine so early, one of the gadipatinārụ's grandsons had offered to drive me to the shrine along with his grandfather. At around 2 am, I finally heard the sound of a car come from the end of an agricultural field and stop in front of the house. I walked into the front yard, which was illuminated by the full moon. The tall and thin figure of the gaḍipatinārụ, who stayed over at the Muṇabettu guttu's house during the nēma, appeared from the shadows of the old house to take his seat in the car. I got in after the gaḍipatinārụ, and his grandson began driving us to the village büta shrine. There were no other cars on the street and only the wind resounded in my ears.

After a while, the village būta shrine, decorated with colourful illuminations, appeared out of the dark of the night. The inside of the shrine precincts were brightly lit, but the surroundings were cast in darkness. The precincts were deserted when we arrived. The gaḍipatinārụ then sat on one of the chairs for the guttu heads, which were set in front of an altar decorated gorgeously with flowers and illuminations. I sat on a stone step on the corner, put on a cardigan to ward off the chill of the night air of the dry season, and looked around the precinct. I saw the gadipatinārụ, in only a loincloth with a white cloth over his bare shoulders, sitting still.

During the nēma, the gadipatinārụ is expected to stay at the shrine the entire time and to wait for the start of a ritual for several hours, thus preventing him from getting enough food and sleep. Once a ritual starts, he should then accompany the deities, respond to their every word and action, evoke and appease the powers of possession, and listen to oracles lasting for hours.

With this in mind, I marvelled at the fact that the gadipatinārụ is already over 80 . 
Looking at the back of his head, which was covered with the white cloth, I noted how his back remained straight and he did not stir an inch. I, meanwhile, repeatedly dozed off and awoke as I waited. Time was passing slowly.

Eventually, another human figure appeared in the precinct. I saw Jayānanda sit cross-legged in a corner and start preparing himself to become Pilicāmuṇdi in the upcoming ritual. He offered a brief prayer at the altar, lit a small light, and made up his face using a small hand-mirror. After a while, one of the ritual workers walked up to the altar to add oil to the votive light and exchanged a couple words with the gadipatinārụ. The sky was still dark, the precinct was still silent, and each person there was silently pursuing his duties while awaiting what was approaching.

What were they waiting for?

The start of the ritual. The coming of the deities.

The encounter of humans and deities, the verges of the umwelt, and the boundary between the realms of jōga and māya - when I think about the between of the actual and the virtual, which I have named in various ways in this book, I always recall not only the manifestation of deities from the realm of māya in the realm of jōga, but also the ways in which people quietly transfer themselves from the realm of jōga to its verges.

Inside the precinct that night, the gadipatinārụ was sitting still in front of the altar. Jayānanda was peering at his mirror, concentrating on making up his face to become a deity. They were present in the same time and space, not exchanging a word, suspending all the disputes and troubles in their daily lives. Both of them were just waiting for the coming of the deity. It was not yet coming, but they anticipated it would be soon, and they knew that the deity would need their help to manifest itself.

In this way, encounters of humans and deities occur not only as deities' visits from the realm of māya, but also as people's approaches to the verges of the realm of jogga. The between of the actual and the virtual gradually appears from within, or soaks through, their serene works of preparation and attitudes of waiting. It is like a slight scent or a vague atmosphere, something too subtle to call radical alterity or to name being/existence.

As we have seen in this book, the certainty of the deity's manifestation in spirit possession and the power of divine orders have been able to actualise būta śakti before people's eyes, and thus to show them the pathisch aspects of their lives in relation to the realm of the wild. At the same time, the attitudes of the people who concentrate on something yet to come and just tranquilly sink into the realm of māya seem to better illustrate the pathisch relationship between humans, deities, and the realm of the wild. The figures of Jayānanda and the gaḍipatinārụ simply waiting for the coming of the deities in the quiet precinct are especially suggestive of one's experience of being in between the realms of jōga and māya. They show the experience 
of temporarily leaving one's ordinary self in the realm of jōga, approaching the realm of māya by giving over oneself to pathos, yet still keeping oneself to the realm of jōga by being a person in relationship with intimate others.

The life-world of the villagers and land and nature, būta śakti and the realm of the wild, and the orders and forces of modernity: I have attempted in this book to describe the relationships between the lives of the people in rural South Kanara and their umwelt as the dynamic and ever-changing interactions of humans and nonhumans in the entanglement of such elements. This attempt shows that investigating the relationships between people and their umwelt is nothing but the turning of our eyes to the limit, or critical phase, of the umwelt. In other words, our endeavour is not only to understand how the world in which people live their everyday lives with various beings $i s$, but also to come close to the vague verges of the world and look into the depths with the people longing to interact with the sakti that fills the unknown realm of māya.

Therefore, the ethnography of the umwelt is also the ethnography of the virtual beyond its borders. The forms of people's lives and their umwelts do not just exist there, but are always becoming. They are transformed together again and again through momentary encounters and interactions between actors in the realm of jōga and virtue or śakti in the realm of māya, encounters and interactions occurring at the obscure and transforming verges of the umwelt. 

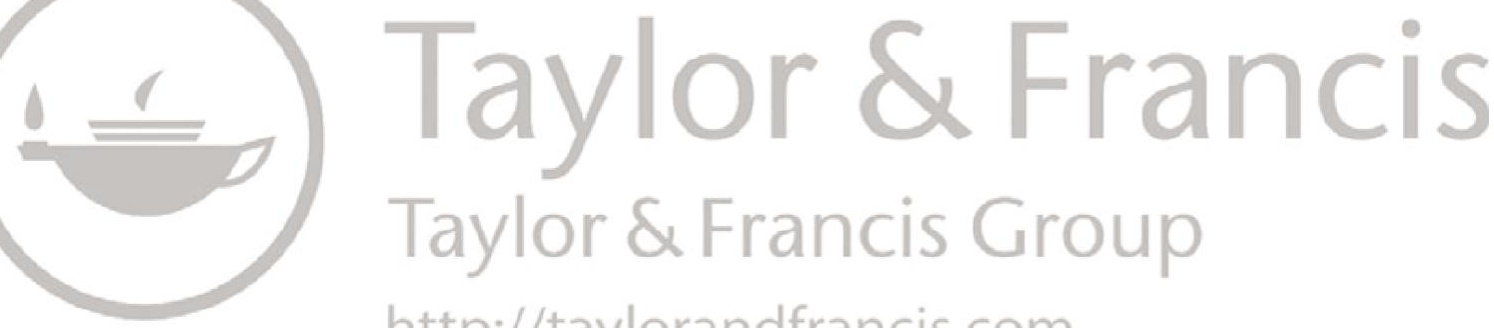

http://taylorandfrancis.com 


\section{Glossary}

Abbreviations of languages: Ka.-Kannaḍa; Ma.-Malayālam; Skt.Sanskrit (other unmarked local terms are from Tuḷ)

Ācāri caste group whose members follow a patrilineal system and have traditionally made their living as carpenters.

adikāra (Skt. adhikāra) authority, power; rank, post, office; administration, governing; responsibility.

Ādi Draviḍa original Dravidian.

Āgalu guttu name of a guttu family belonging to Tenka Yekkar village.

āja an oath; swearing; curse.

ajjererụdụ baidena property inherited from grandfather (maternal ancestral property).

ākarṣaṇ attraction; a ritual to invoke a spirit.

Alake guttu the fifth-ranked guttu family in Perar.

aliya nephew; son-in-law.

ạ̣iyasantāna kațtụ (aliyakațtụ) matrilineal system of inheritance.

Ālupa (Āḷva) name of the royal family in South Kanara in the early Âlupa period.

Āluvarasa name of a ruler in South Kanara in the early Ālupa period.

ame period of ceremonial impurity after child birth, usually spanning three, seven, ten, sixteen, forty-one, or forty-eight days.

ani a kind of ornamental halo-like adornment made of areca spathes, cloth, tender coconut leaves, or metal materials, and worn on the back by a būta dancer.

aramanege saluva bhaṇ̣̄āra-sthạa villages and cultivable land owned by the state in the Vijayanagara period.

Arasu (Iśtadēvate, u!̣̂āklụ) one of the primary būtas in the village būta shrine in Perar.

arụdala a lace-like design painted on the face of a büta dancer-medium.

asrānna a Brahman priest serving at the shrine to Bramma in Perar.

aștamanigala praśne an astrological method of asking questions, involving the placement of eight kinds of auspicious things, such as a lamp, mirror, gold, milk, curds, fruits, etc. 
asudda (Skt. aśuddha) ritual pollution, ceremonial impurity.

àti the period from mid-July to mid-August in the Tulu calendar.

āvēśa possession by spirits or other supernatural powers; subservience; zeal, enthusiasm; happiness.

baccire the betel leave, Piper betle.

bagayat land suitable for cultivation of areca nuts and coconuts.

bailụ (bayilụ) a plain, a region with a multitude of rice fields, a wet land; fertile fields situated on a low land.

bākimārụ a large open field at the doorstep; field in front of a house, usually growing one crop.

Balavāṇdi one of the primary būtas of the village būta shrine in Perar.

bāḷ life, subsistence; land wealth in the Âlupa period.

baṇḍārada koṭa the house where the sacred ornaments and other ritual objects of the bütas are kept.

Baṇ̣̂āi caste group whose members have traditionally made their living as barbers.

Baṇta (Baṇterụ, Okkelakulu) one of the dominant caste groups in South Kanara.

Baṇtakamba the holy place at which Balavāṇdi, the primary deity in Perar, is believed to have appeared.

Bārakūru rājya one of the two parts of South Kanara in the Vijayanagara period.

bari descent, clan, lineage, race, family, kith, and kin.

bārne a ritual in which food and drink are offered to the deity.

basava white cow.

bațtalụ kāṇike kambu!̣a one of the kambuḷa rituals dedicated to the būtas and organised by the Mundabețtu guttu in Perar.

Baț̣̦ụ/Brahman caste group.

Belcade caste group.

beśa the period from mid-May to mid-June in the Tulu calendar.

bhaṇāara-sthala villages and cultivable land owned by the state in the Vijayanagara period; land which was not tax-free in Kanara in the medieval period.

bharti one of the holdings classified by the collector H. Viveash in 1834, on which it was possible to pay all the tax levied by the fixed assessment.

bhukti (Skt. bhukti) enjoyment, pleasure, ownership.

birāvụ a silver stick.

bolgode a small decorated umbrella used in temple processions.

Bolinji Guḍ̣̂ Bolinji Mountain.

bōntelụ the period from mid-October to mid-November in the Tulu calendar.

boțtu (bețtu) land located at a higher level than bailụ, and dry except for during the rainy season, which is suitable for single cropping.

brahmakalaśa a purification ritual undertaken when a deity's statue is enshrined. 
Bramma (Bermerụ, Brammabermerụ, Brammadēvarụ, Nāgabramma) the deity regarded as the highest-ranked büta in the village būta shrine in Perar; the deity is often identified with the Hindu god Brahma.

brammalinga a stone statue enshrined in the Bramma shrine in Perar.

brammere gunda (Bramma gunḍa) a shrine to Bramma in the village shrine in Perar.

Brāṇabețtu guttu (Bernoṭtu guttu) the second-ranked guttu family in Perar.

būta apotheosised local heroes or heroines, or the spirits of wild animals dwelling in forests, which are generally regarded as deities.

būta kallụ a būta's stone.

būta pattuṇ̣u attraction of or possession by a būta.

būta śakti a būta's power.

būtoda upadro misfortunes caused by būtas.

cākiridakulu workers serving the village būta shrine in Perar.

cāla gēṇi tenants employed on the basis of annual or seasonal contracts.

carva pedestal used in the büta ritual.

cāvạ̣i open hall in a traditional manor house in South Kanara; an administrative unit in South Kanara in the Vijayanagara period.

Chandrashekara the name of a king who appears in the oral epic of Perar. daiva an honorific for a būta.

daivada jāgụ the land believed to belong to a büta dwelling in the land. daivaśakti a deity's power.

Dakșiṇa Kannaḍa South Kanara.

darśana (Skt.) a particular type of blessing from the deity, conveyed through the eyes.

darșana vision, sight; trembling due to possession by deities.

desśa the largest administrative unit in South Kanara in the Vijayanagara period.

dêva patțe land transfer made in a deity's name, in which the deity held proprietary rights.

dharma (Skt. dhárma) ordinance, law; usage, practice, duty; virtue, morality.

dōlu double-headed drum.

Durgā one of the Hindu goddesses, who is believed to be the wife of the god Shiva.

enelu the first crop planted in the month of beśa.

enne detonuni the ritual in which Balavāṇdi receives sacred oil.

gaḍi boundary, limit, frontier; authority, ownership, headship, responsibility.

gaḍipatinārụ the person who takes authority/responsibility (gadi); the primary patron of the village büta shrine in Perar.

gaggara sacred anklets worn by a būta dancer-medium.

gaggara decci the initial dance of a būta dancer-medium wearing sacred anklets. 
gaggara dīpuni the dance of a būta dancer-medium as a part of the yearly ritual.

gandha the sandalwood tree; the scent of flowers and sandalwood paste. gẹni the share of agricultural produce or amount paid by tenants or cultivators to land owners; land tenancy or rent paid to landholders by tenants in South Kanara in the Âlupa period.

gēṇi okkelụ a tenant.

grāma a village; an administrative unit in South Kanara in the Vijayanagara period.

grāmada daiva a village deity.

grāmani a title for village administrative officers in the Vijayanagara period.

guḍde a small hill, forest.

Guliga name of a būta.

guttu a manor house, the family responsible for organising the rituals in a village; an administrative unit in a village in South Kanara in the Vijayanagara period.

inām (ināmụ) a gift, presentation; tax-free land.

innūrāla arasu king over two hundred people.

jagattu one of the village administrative organisations in South Kanara in the Vijayanagara period.

jāgeda daiva land būtas thought to dwell in the land.

Jain followers of Jainism. Jain landlords exercised power in administrative districts called māgane in South Kanara in the Vijayanagara period.

jakkelaṇi a crescent-shaped flat decoration made of coconut leaves, worn across the waist of a büta dancer-medium.

janasańkyepālụ division of property on the basis of population.

jārụd $\varepsilon$ the period from mid-November to mid-December in the Tulu calendar. jāti caste group.

jōga physical world, human form, existence, reality; ecstasy, possession by spirits or gods.

jōga āpini manifestation of būtas in spirit possession.

Jōgile Bailụ Jōgi’s Plain.

Jumādi one of the powerful būtas in South Kanara.

kabarụ (Ka. kavalu) a sub-group of the matrilineal joint family called kuțuma.

kabarụpālụ division of property on the basis of kabarụ.

kadar mudi a long board which is a part of the costume of Arasu.

kaddatams 'black books' with revenue reports over several centuries, which Thomas Munro insisted be maintained in Kanara.

kaḍale a silver sword used by the mukkāldi in the būta ritual.

kalaśanīrụ sacred water in a pot.

kalaśasnāna (kalaśaśuddhi) purification ritual for būta priests and dancermediums conducted by a Brahman priest.

ka!̣ase a local measure of volume of grain equal to ten or fourteen sērụ. 
kāli okkelụ domestic labourers who lived on landlords' estates and performed a variety of tasks.

kallāla an interim priest for the kambula ritual in Perar.

Kallurți name of a lower-ranked (kāṭ̣) būta.

Kallurți Pañjūrli name of a būta.

kambharti one of the holdings classified by the collector H. Viveash in 1834, on which it was not possible to pay all the tax levied by the fixed assessment.

kambu!̣ (kamba!a) a buffalo race in a paddy field or river canal; a field in which the buffalo race takes place; a ritual performed in the rice field for fertility.

kanciul bali a ritual held for children's health and for the resolution of family problems.

Kandettāya one of the five būtas standing one rank below the three royal būtas.

kānike tax paid by buyers of land to the state treasury in the Keladi Nāyaka period.

Kāntiri Jumādi name of a būta.

kāraṇīkerụ a man with supernatural powers.

kațale custom, practice; order, rule, commandment, regulation; habit, convention.

katterimane a wooden couch used in the būta ritual.

kațtu custom, heritage, observance; law, rule, regulation; traditional, customary.

katṭu kațtale customs and traditions.

kațtu-kațtụleda āvāra a ritual of offering food to a deity according to custom.

kāṭu wild, rough, rude; uncultured; untamed.

kāṭ̣ būta the wild, untamed būtas.

Kavaramane guttu the highest-ranked guttu family in Tenka Yekkar village.

kēpla a flowering plant, Ixora coccinea.

kesarụkallụ pāḍuni a ceremony of laying a foundation stone.

Kinnimajālụ the general name of the place consisting of the Bantakamba, village būta shrine, and treasury in Perar.

Koḍamaṇittāya name of a būta.

koḍi jāpuni a ritual involving taking down a flag held on the final night of the nēma.

koḍiyaḍi an altar on the premises of a būta shrine.

kola būta ritual.

kolake the third crop planted in the month of puyintelụ.

kōlu a stick.

kombu a wind instrument.

Koratāi Balardi a Jain woman who was said to be the head of the Muṇ̃abețtu guttu. 
Kuḍubi (Kuḍubi-Gauḍa) caste group whose members follow the patrilineal system and whose ancestors are said to have come from Goa.

kudure a wooden horse used in the būta ritual.

kumeru high and dry land where several kinds of vegetables suitable for arid land are cultivated.

kumki a portion of forest or uncultivated land from which the cultivator or owner of nearby land has the privilege of using wood as well as leaves and twigs for manure, fodder, etc.

kuṭuma (Ka. kuṭumba) a matrilineal joint family, a lineage; a group of relatives who practise the customary observances related to births and deaths in a family.

kuṭumada būmi traditional family land.

kuṭumada daiva būtas worshipped by the members of a joint family.

Lingayat one of the dominant landlord castes in Karnataka.

māọa a shrine for Arasu in the village būta shrine in Perar; a bell used by the mukkāldi in the būta ritual.

madalụ muḍepuni ritual ornaments made from coconut fronds that symbolise farmland greenery.

Maḍdyelc (Mạ̣ivāla) caste group whose members follow a matrilineal system and traditionally have been engaged in washing clothes.

madhyastha a title for village administrative officers in the Vijayanagara period.

maḍi cleanliness, purity; ritual purity.

madụmālụ a bride; a pubescent female.

madyaste the head of the second manor or guttu family in Perar.

māgaṇe a medium-sized administrative unit in South Kanara in the Vijayanagara period.

mahālaya the offerings and obsequies made to ancestors during the second fortnight of the sixth lunar month.

mahālaya amāse the new moon day of the mahālaya fortnight.

majalu land suitable for double cropping.

makkạa kațtu patrilineal system of inheritance.

makkaḷa santāna inheritance from father to son.

malpāvunāye the manager of the būta ritual at the family level.

mañcāvu a cot; a būta altar.

manḍala the largest administrative unit in South Kanara in the Vijayanagara period.

manc daiva būtas worshipped by the members of a household.

Mangalūru (Mangaluru) the town of Mangalore; one of the capitals of South Kanara.

Mangaḷuru rājya one of the two parts of South Kanara in the Vijayanagara period.

Mañgāra the old name of Mangaluru.

māni a būta medium.

Manibottu Brammērụ name of the deity enshrined in a shrine in Kaje. 
manjotti a place near the kambula field.

Manșa caste group.

Mantradēvate one of the būtas categorised as kāṭu būta, or the wild, untamed būta.

Māri village goddess considered to be the presiding deity of epidemic diseases; small pox.

marumakkattāyam the form of matriliny that prevailed among the Nayars in Kerala.

māya mystery, disappearance.

māya āpuni vanishing of deities.

māyagarlu intangible entities.

māyaka vanishing, fleeting, passing away, disappearing.

māya maḷpuni making someone disappear.

māyi the period from mid-February to mid-March in the Tulu calendar.

mayilige ritual pollution, ceremonial impurity.

mittakare highland; the elevated area of a village or plain.

moktēsare a trustee, manager of a temple; a principal resident of a village.

Moyli (Sapalya, Sērigāre, Dēvaḍige) caste group whose members follow a matrilineal system.

mrityuñjayahōmo a ritual for saving lives.

muḍi a measure of grain, etc., amounting to about 39 kilograms or 42 seers. muḍi gēṇi a unit of weight of paddy paid as rent.

muga a mask made of metal or areca-palm spathe.

muga pattuni (muga dīpuni) a ritual in which a Maḍdyele worker ties the mask of Pilicāmuṇdi onto the centre of ani.

mukkāldi a būta medium-priest; one of the village administrative organisations in the Vijayanagara period.

mukkālụ mūji galige a period of time lasting for three seconds.

mūla a root, origin; family; main, principal, original; hereditary, customary.

mūla gēṇi families of tenants working on a particular piece of land over several generations.

mūla hakkụ ownership of land.

mūla stāna a place of origin.

mūlawargdār original or hereditary holder of an estate or warg.

mūliga farmers who permanently borrowed cultivable land from land owners in the Âlupa period.

Mundạabețu (Mundọtoțu) guttu the highest-ranked guttu family in Perar. mūve rullākulu onjii mañcāvuḍu ullerụ three uḷạkḷ̣ on one couch.

mūverullākulદ cāvaḍi hall for the three kings.

Nādu the name of an earlier avatar of Balavāndi.

naḍu cōrṇa a red banner used in the būta ritual.

nāọu one of the administrative units in South Kanara in the Vijayanagara period. 
nāga (Nāga) snake, cobra; deity in the form of a serpent.

nāgabana a grove reserved for Nāga shrines.

nāgamañḍala a night-long ritual dedicated to the Nāgas.

nāgarapanicami a ritual to the Nāgas performed by a Brahman priest in the month of āti.

Nalike caste group whose members have played the role of būta dancermediums in South Kanara.

navaratna nine precious gems.

nēji young rice plants.

Nellidādi guttu the fourth-ranked guttu family in Bajpe village.

nēma the annual festival of a būta shrine, conducted with great pomp.

nēma decci a part of the performance of dancer-mediums in the nēma; shivering of the būta dancer-medium's body during the nēma.

nirnāla the period from mid-September to mid-October in the Tulu calendar.

nissamtati (Ka.) childless.

nissamtati kavalu (Ka.) a kavalu that has no female member under the age of 50 years and is hence regarded as having no possibility of maintaining the matrilineal line.

nișt $\varepsilon$ firmness, devotion, being devout.

niyama (Skt. niyama) rules and regulations, system, order; religious observance; a rule, law.

niyama niște devoting oneself to the rule.

nuḍi korpuni blessings.

nuḍikattụ prophecy uttered by the būta incarnated in a medium; words of judgement and instruction; reply given to the devotee's problems, complaints, etc.

nuga a yoke.

okkalu the smallest administrative unit in South Kanara in the Vijayanagara period.

okkelu tenancy; agricultural tenancy; a tenant.

onjappa jōkulu the children of one mother.

pāḍana oral epic.

padiari pattuni the ritual held in the evening of the day prior to the nēma. paggu the period from mid-April to mid-May in the Tulu calendar.

Pambada caste group whose members follow a matrilineal system and have played the roles of dancers as well as mediums of the higher-ranked būtas in South Kanara.

Pambadere Kōdi Pambada's Hilltop.

pañcalōha an alloy of five metals, such as copper, brass, tin, lead, and iron. pañcāmṛta abhiṣēka five kinds of liquids poured onto the stone of Nāga during nāgarapañcami.

panikụ kulluni a ritual held during the kambula ritual in Perar.

Pañjūrli name of a būta.

pāpe a statue. 
parake a vow made to perform certain rituals or to offer gifts to deities.

Parava caste group whose members have played the role of būta dancermediums in South Kanara.

parva auspicious day on which festivals and rituals are held.

pātri (māni) a būta medium.

patta royal jurisdiction; land deed.

patțadār landholder; holder of land deed.

pațtadārti female landholder; holder of land deed.

patterụ honourable members or elders of a village; head of a village.

patte record of right to landed property; registered document.

pați land donated to religious institutions in South Kanara in the Keladi Nāyaka period.

Pejattāya a Brahman family that occupies the highest position in the hierarchy regarding būta worship in Perar.

perārde the period from mid-December to mid-January in the Tulu calendar.

pergaḍe chieftain, headman; an honorific title.

Pērīrụ the lowest-ranked guttu family in Perar.

Perra the old name of Perar.

Pilicāmuṇ̦̣i tiger būta, one of the main būtas in the village būta shrine in Perar.

Poduvāl caste group. People in South Kanara often invite astrologers from Kerala who belong to this community.

prabāvali a golden halo of the stone statue of Bramma.

prakrti (Skt. prakriti) nature, the natural state of anything, the root, cause, and origin.

prasāda food, flower, sandal, etc. offered to deities and given to devotees as blessings of the deity; blessings.

pūjā (pūjana) worship, service, offering.

Pūjāri (Billava, Bayidya) caste group whose members follow a matrilineal system, who have traditionally made their living as toddy tappers, and have played an important role in būta worship as priests called pātri or māni.

pūkare an ornamental post decorated with flowers, set with specific rituals in particular paddy fields and the kambula fields to ward off evil spirits.

punarụ pratisțhe a ritual conducted for the opening of a reconstructed shrine.

puṇname rituals for Arasu and Balavāṇdi held from the first night to the next morning of the nēma.

Puruṣa (Jōgi) caste group whose members follow a patrilineal system and have traditionally made their living as musicians.

pūve a flag-hoisting ritual held from the previous night to the morning of the first day of the nēma.

puyintelu the period from mid-January to mid-February in the Tulu calendar. 


\section{Glossary}

raīyatwārī (ryotwari) the land tenure and tax system promoted by Thomas

Munro in Kanara.

rājanụ daiva royal būta.

rājanụ daiva savāri a path of the royal deity.

rājya the largest administrative unit in South Kanara in the Vijayanagara period.

Raktēśvari name of a female buta, believed to be the incarnation of the mother goddess.

rasa sentiment.

rūpa form, shape; beauty; figure; garments of a būta dancer.

śakti the divine power of deities; the power, potency, or activating energy incarnated in goddesses.

saṃtati family, progeny, offspring; lineage, race.

samtati kavalu a kavalu that contains at least one female member who is

not yet 50 years old and, hence, has a possibility of maintaining the matrilineal line.

samudāya collective tax or contribution in the Âlupa period.

sāna shrine.

sanigita a kind of music that is usually sung or performed vocally.

sankrānti the passage of the sun from one sign of the zodiac to another; transition period.

śānta calmness; tranquillity.

śānta svabhāva the calm state of mind of the būta dancer-medium during the possession ritual.

santāna lineage, family.

Śāstāvu the name of a place, and the 13th-ranked guttu family in Perar.

Śāstāvu Bramma a Hindu shrine worshipped by Kuḍbis in Mudu Perar. sattige umbrellas used in the būta ritual.

Satyadēvate name of a būta.

savāri riding; going out of doors or abroad, journey; arrival, coming; roaming, wandering.

sāvirāla arasu king over one thousand people.

sērụ a measure of grain or liquid (about a kilogram).

sīme an administrative unit in South Kanara in the Vijayanagara period.

sōna the fifth solar month; a month considered to be auspicious.

stāna a place, location; dwelling place; position; shrine of gods and bütas.

sudda (Skt. śuddha) ceremonial purification, cleanliness.

suggi the period from mid-March to mid-April in the Tulu calendar; the second crop planted in the month of bōntelụ.

Sundotțu guttu the first-ranked guttu family in Bajpe village.

suriya pāọonuni a ritual performed at Banțakamba as a part of the yearly ritual in Perar.

sūtaka ritual impurity from the death of kinsmen; ritual impurity from childbirth in the family; pollution due to menstruation.

svabhāva one's natural temper, disposition, nature, natural behaviour. 
taravāțŭ (Ma.) the joint family in the matrilineal society among the Nayars in Kerala.

tastiku the allowance granted by the government to a religious institution. Tidyamunḍoț̣ guttu the third-ranked guttu family in Perar.

tiri a skirt made of torn coconut leaves and worn by a būta dancer-medium. tirtakare lowland.

Tòdu guttu the highest-ranked guttu family in Permude village.

toḷasi a sacred basil, holy basil, Ocimum sanctum.

tuḍara bali a ritual held prior to the yearly ritual in Perar.

Tulunādụ the Tulu country; South Kanara.

tūvonunaye the manager of the büta ritual at the village level.

ujjālụ a swing.

ulaguttu sub-guttu.

ula kabarụ sub-kabarụ.

ulamūlagẹni subtenant.

Uliya the 12th-ranked guttu family in Perar.

u!̣ākḷu the honorific title of a person of high rank.

umbali land without rent granted for the performance of certain services in temples or other public services; tax-free land granted to cākiridakulu families in Perar; land required for the purpose of self-sufficiency in the Keladi Nāyaka period.

ūru an inhabited place, village, town; one's native place; people of a locality.

uttāra land as a source of income for special use, such as for ritual purposes, in the Keladi Nāyaka period. vādya musical instrument.

vākụ piripuni a ritual to abrogate a vow in front of deity and reconstruct the relationship between relatives; the ritual of the butas' judgment.

varaha the standard 3.4-gram gold coin used in the Vijayanagara period. Vokkaliga one of the dominant landlord castes in Karnataka.

warg (varga) estate; tenure of land, proprietary right, proprietary land. wargdār (vargadār) holder of a warg.

yajamāne (Ka. yajamāna) master, lord, head of a house, the senior member of a family.

yajamāni (Ka. yajamāni) mistress, landlady; wife. 

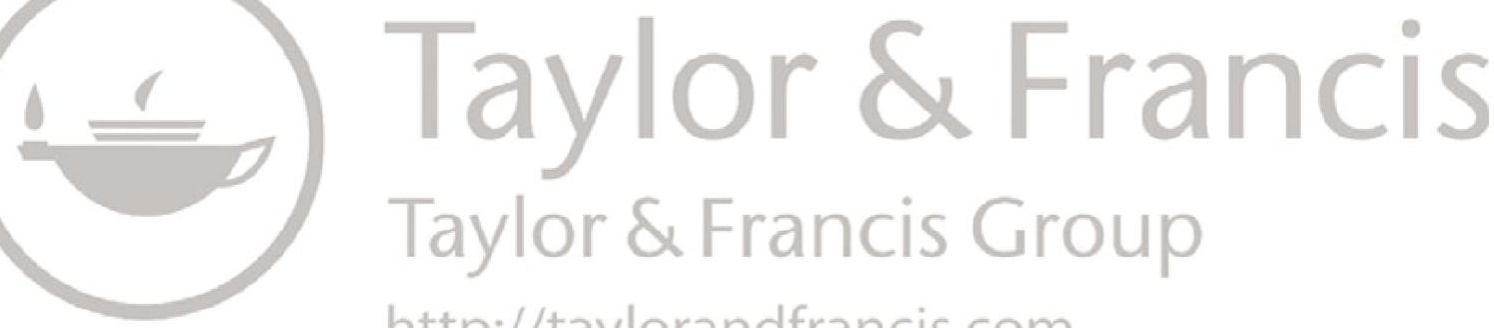

http://taylorandfrancis.com 


\section{Bibliography}

Abhishankar, K (ed.) 1973, Karnataka State Gazetteer: South Kanara district, Government of Karnataka Publication, Bangalore.

Appadurai, A 1981, Worship and conflict under colonial rule: A South Indian case, Cambridge University Press, Cambridge, doi: 10.1017/cbo9780511557934

Appadurai, A \& Breckenridge CA 1976, 'The South Indian temple: Authority, honour and redistribution', Contributions to Indian Sociology, vol. 10, no. 2, pp. 187-211, doi: 10.1177/006996677601000201

Arbuthnot, AJ 1889, Major-general sir Thomas Munro, Kegan Paul, Trench \& Co, London.

Arnold, D \& Guha, R (eds.) 1995, Nature, culture, imperialism: Essays on the environmental history of South Asia, Oxford University Press, New Delhi, doi: 10.1080/03612759.1996.9952540

Asad, T 1986, 'The concept of cultural translation in British social anthropology', in J Clifford \& EG Marcus (eds.), Writing culture: The poetics and politics of ethnography, University of California Press, Berkeley, pp. 141-164.

Babadzan, A 1993, 'Les dépouilles des dieux: Essai sur la religion tahitienne à l'époque de la découverte', Maison des Sciences de l'Homme, Paris, doi: 10.2307/3034008

Baden-Powell, BH 1907, A short account of the land revenue and its administration in British India: With a sketch of the land tenures, The Clarendon Press, Oxford.

Baden-Powell, BH 1990 (1892), The land-systems of British India, vol. 3, Low Price Publications, Delhi.

Barraud, C, de Coppet, D, Iteanu, A \& Jamous, R 1994, Of relations and the dead: Four societies viewed from the angle of their exchanges, trans. SJ Suffern, Berg, Oxford, doi: 10.1017/s0041977x00029244

Beaglehole, TH 1966, Thomas Munro and the development of administrative policy in Madras 1792-1818: The origins of 'the Munro system', Cambridge University Press, Cambridge, doi: 10.1086/ahr/72.1.265

Bedi, HP 2013, 'Special economic zones: National land challenges, localized protest', Contemporary South Asia, vol. 21, no. 1, pp. 38-51, doi: 10.1080/09584935.2012.757582

Behrend, H \& Luig, U (eds.) 1999, 'Introduction', in Spirit possession: Modernity and power in Africa, The University of Wisconsin Press, Madison, pp. xiii-xxii, doi: 10.2979/aft.2001.48.3.159

Benjamin, W 1966, Angelus Novus: Ausgewählte Schriften 2, Suhrkamp Verlag, Frankfurt. 
Bhat, MVS 2004, Aliyasantana law, Lex Publishers, Mangalore.

Bhat, NS 1998, South Kanara (1799-1860): A study in colonial administration and regional response, Mittal Publications, New Delhi.

Bhatt, PG 1975, Studies in Tuluva history and culture: From the pre-historic up to the modern, Manipal Power Press, Manipal.

Bird-David, N 1999, “Animism” revisited: Personhood, environment, and relational epistemology', Current Anthropology, vol. 40, no. S1, pp. S67-91, doi: $10.1086 / 200061$

Blankenburg, W (ed.) 1991, Wahn und Perspektivität: Störungen im Realitätsbezug des Menschen und ihre Therapie, Ferdinand Enke Verlag, Stuttgart.

Boddy, J 1988, 'Spirits and selves in northern Sudan: The cultural therapeutics of possession and trance', American Ethnologist, vol. 15, no. 1, pp. 4-27, doi: 10.1525/ ae.1988.15.1.02a00020

Boddy, J 1989, Wombs and alien spirits: Women, men, and the zãr cult in northern Sudan, The University of Wisconsin Press, Madison, doi: 10.2307/2803851

Boddy, J 1994, 'Spirit possession revisited: Beyond instrumentality', Annual Review of Anthropology, vol. 23, pp. 407-434, doi: 10.1146/annurev.anthro.23.1.407

Bradshaw, J 1894, Sir Thomas Munro and the British settlement of the Madras presidency, The Clarendon Press, Oxford.

Brückner, H 2009, On an auspicious day, at dawn...: Studies in Tulu culture and oral literature, Harrassowitz Verlag, Wiesbaden.

Busby, C 1997, 'Permeable and partible persons: A comparative analysis of gender and body in South India and Melanesia', Journal of the Royal Anthropological Institute, vol. 3, no. 2, pp. 261-278, doi: 10.2307/3035019

Candea, M 2010, “I fell in love with Carlos the meerkat": Engagement and detachment in human-animal relations', American Ethnologist, vol. 37, no. 2, pp. 241-258, doi: 10.1111/j.1548-1425.2010.01253.x

Candea, M 2011, 'Endo/Exo', Common Knowledge, vol. 17, no. 1, pp. 146-150, doi: $10.1215 / 0961754 x-2010-046$

Carrithers, M, Collins S \& Lukes, S (eds.) 1985, The category of the person: Anthropology, philosophy, history, Cambridge University Press, Cambridge, doi: $10.1177 / 001946468602300405$

Carse, A 2012, 'Nature as infrastructure: Making and managing the Panama Canal watershed', Social Studies of Science, vol. 42, no. 4, pp. 539-563, doi: 10.1177/ 0306312712440166

Carsten, J 2011, 'Substance and relationality: Blood in contexts', Annual Review of Anthropology, vol. 40, pp. 19-35, doi: 10.1146/annurev.anthro.012809.105000

Chitnis, KN 1974, Keladi polity, Karnatak University Press, Dharwar.

Ciekawy, D \& Geschiere, P 1998, 'Containing witchcraft: Conflicting scenarios in postcolonial Africa', African Studies Review, vol. 41, no. 3, pp. 1-14, doi: $10.2307 / 525351$

Claus, PJ 1978, 'Oral traditions, royal cults and materials for a reconsideration of the caste system in South India', Journal of Indian Folkloristics, vol. 1, no. 1, pp. $1-25$.

Claus, PJ 1984, 'Medical anthropology and the ethnography of spirit possession', Contributions to Asian Studies, vol. 18, pp. 60-72.

Claus, PJ 1991, 'Kin songs', in A Appadurai, FJ Korom \& MA Mills (eds.), Gender, genre, and power in South Asian expressive traditions, University of Pennsylvania Press, Philadelphia, pp. 136-177, doi: 10.2307/2059403 
Comaroff, J 1985, Body of power, spirit of resistance: The culture and history of a South African people, The University of Chicago Press, Chicago, IL, doi: 10.1017/ s0021853700029911

Comaroff, J \& Comaroff, JL 1993, 'Introduction', in J Comaroff \& JL Comaroff (eds.), Modernity and its malcontents: Ritual and power in postcolonial Africa, The University of Chicago Press, Chicago, IL, pp. xi-xxxvii, doi: 10.1525/ ae.1995.22.4.02a01310

Comaroff, J \& Comaroff, JL 1999, 'Occult economies and the violence of abstraction: Notes from the South African postcolony', American Ethnologist, vol. 26, no. 2, pp. 279-303, doi: 10.1525/ae.1999.26.2.279

Comaroff, J \& Comaroff, JL 2001, 'Millennial capitalism: First thoughts on a second coming,, in J Comaroff \& JL Comaroff (eds.), Millennial capitalism and the culture of neoliberalism, Duke University Press, Durham, NC, pp. 1-56, doi: 10.1215/9780822380184-001

Comaroff, J \& Comaroff, JL 2002, 'Alien nation: Zombies, immigrants, and millennial capitalism', The South Atlantic Quarterly, vol. 101, no. 4, pp. 779-805, doi: 10.1215/00382876-101-4-779

Comaroff, JL \& Comaroff, J 1992, Ethnography and the historical imagination, Westview Press, Boulder, CO.

Cook, I, Bhatta R \& Dinker, V 2013, 'The multiple displacements of Mangalore special economic zone', Economic and Political Weekly, vol. XLVIII, no. 33, pp. 40-46, doi: 10.1086/ahr/99.1.194

Copeman, J 2005, 'Veinglory: Exploring processes of blood transfer between persons', Journal of the Royal Anthropological Institute, vol. 11, no. 3, pp. 465-485, doi: 10.1111/j.1467-9655.2005.00246.x

Copeman, J 2009, Veins of donation: Blood donation and religious experience in North India, Rutgers University Press, New Brunswick, NJ, doi: 10.1017/s0021911809992373

Copeman, J 2011, 'The gift and its forms of life in contemporary India', Modern Asian Studies, vol. 45, no. 5, pp. 1051-1094, doi: 10.1017/s0026749x11000205

Damle, CB 1991, 'Agrarian relations and land reforms in Dakshina Kannada district, Karnataka', in Editorial committee (ed.), Perspectives on Dakshina Kannada and Kodagu, Mangalore University, Mangalagangotri, pp. 145-159, doi: 10.15373/22778160/mar2014/17

Daniel, EV 1984, Fluid signs: Being a person the Tamil way, University of California Press, Berkeley.

de Bruin, HM 2006, 'Donning the vēṣam in Kațtaikkūttu', in D Shulman \& D Thiagarajan (eds.), Masked ritual and performance in South India: Dance, healing, and possession, University of Michigan Press, Ann Arbor, pp. 107-134.

de la Cadena, M 2015, Earth beings: Ecologies of practice across Andean worlds, Duke University Press, Durham, NC, doi: 10.7440/antipoda26.2016.09

de Laet, M \& Mol, A 2000, 'The Zimbabwe bush pump: Mechanics of a fluid technology', Social Studies of Science, vol. 30, no. 2, pp. 225-263, doi: 10.1177/030631200030002002

Deleuze, G 1991, Bergsonism, trans. H Tomlinson, B Habberjam, Zone Books, New York.

Deleuze, G 1994, Difference and repetition, trans. P Patton, Columbia University Press, New York.

Descola, P 1996, 'Constructing natures: Symbolic ecology and social practice', in P Descola \& G Pálsson (eds.), Nature and society: Anthropological perspectives, Routledge, London, pp. 82-102, doi: 10.4324/9780203451069_chapter_5 
Dhakal, SC 2009, A report of people's audit of SEZ Karnataka, Tata Institute of Social Sciences (TISS), Mumbai, viewed 14 October 2016, www.indiaenvironmentportal. org.in/files/KarnatakaReportfinal.pdf

Dirks, NB 1987, The hollow crown: Ethnohistory of an Indian kingdom, Cambridge University Press, Cambridge.

Dirks, NB 1992, 'Ritual and resistance: Subversion as a social fact', in D Haynes \& G Prakash (eds.), Contesting power: Resistance and everyday social relations in South Asia, University of California Press, Berkeley, pp. 213-238.

Dumont, L 1965, 'The functional equivalents of the individual in caste society', Contributions to Indian Sociology, vol. 8, pp. 85-99.

Dumont, L 1970, Religion/politics and history in India: Collected papers in Indian sociology, Mouton Publishers, The Hague.

Dumont, L 1980, Homo hierarchicus: The caste system and its implications (complete revised English edn.), trans. M Sainsbury, L Dumont, B Gulati, The University of Chicago Press, Chicago.

Dumont, L \& Pocock, DF 1959, 'Pure and impure', Contributions to Indian Sociology, vol. 3, pp. 9-39.

Eck, DL 1998(1981), Darśan: Seeing the divine image in India, 3rd edn., Columbia University Press, New York.

Englund, H \& Leach, J 2000, 'Ethnography and the meta-narratives of modernity', Current Anthropology, vol. 41, no. 2, pp. 225-248, doi: 10.2307/3596698

Fabian, J 1978, 'Popular culture in Africa: Findings and conjectures', Africa: Journal of the International African Institute, vol. 48, no. 4, pp. 315-334, doi: $10.2307 / 1158799$

Farole, T 2011, 'Special economic zones: What have we learned?', Economic Premise: Poverty Reduction and Economic Management Network, vol. 64, pp. 1-5, viewed 23 August 2014, www.worldbank.org/economicpremise

Frasca, RA 1990, The theater of the Mahābhärata: Terukkūttu performances in South India, University of Hawai'i Press, Honolulu.

Freeman, R 1999, 'Dynamics of the person in the worship and sorcery of Malabar', in J Assayag \& G Tarabout (eds.), La possession en Asie du sud: Parole, corps, territoire, École des Hautes Études en Sciences Sociales, Paris, pp. 149-181, doi: 10.7202/012624ar

Fuller, CJ 1979, 'Gods, priests and purity: On the relation between Hinduism and the caste system', Man, vol. 14, no. 3, pp. 459-476, doi: 10.2307/2801869

Fuller, CJ 1984, Servants of the goddess: The priests of a South Indian temple, Cambridge University Press, Cambridge.

Fuller, CJ 1988, 'The Hindu pantheon and the legitimation of hierarchy', Man, vol. 23 no. 1, pp. 19-39, doi: 10.2307/2803031

Fuller, CJ 2003, The renewal of the priesthood: Modernity and traditionalism in a South Indian temple, Princeton University Press, Princeton, NJ, doi: 10.1086/511453

Fuller, CJ 2004, The camphor flame: Popular Hinduism and society in India (revised and expanded edn.), Princeton University Press, Princeton, NJ, doi: $10.1515 / 9780691186412$

Fuller, CJ \& Moore, MA 1986, 'The Nayar taravad', Man, vol. 21, no. 1, pp. 135-137.

Gad, C, Jensen, CB \& Winthereik, BR 2015, 'Practical ontology: Worlds in STS and anthropology', Nature Culture, vol. 3, pp. 67-86.

Gadgil, M \& Guha, R 1992, This fissured land: An ecological history of India, University of California Press, Berkeley, doi: 10.2458/v1i1.21162 
Gell, A 1995, 'Closure and multiplication: An essay on Polynesian cosmology and ritual', in D de Coppet \& A Iteanu (eds.), Cosmos and society in Oceania, Berg, Oxford, pp. 21-56.

Gell, A 1997, 'Exalting the king and obstructing the state: A political interpretation of royal ritual in Bastar district, Central India', The Journal of the Royal Anthropological Institute, vol. 3, no. 3, pp. 433-450, doi: 10.2307/3034761

Gell, A 1998, Art and agency: An anthropological theory, The Clarendon Press, Oxford.

Gellner, E 1970, 'Concepts and society', in BR Wilson (ed.), Rationality, Basil Blackwell, Oxford, pp. 18-49.

Geschiere, P 1997, The modernity of witchcraft: Politics and the occult in postcolonial Africa, trans. P Geschiere, J Roitman, The University Press of Virginia, Charlottesville, doi: 10.1353/jsh.1999.0002

Geschiere, P 1999, 'Globalization and the power of indeterminate meaning: Witchcraft and spirit cults in Africa and East Asia', in B Meyer \& P Geschiere (eds.), Globalization and identity: Dialectics of flow and closure, Blackwell Publishers, Oxford, pp. 211-237, doi: 10.1111/1467-7660.00100

Gough, EK 1952, 'Changing kinship usages in the setting of political and economic change among the Nayars of Malabar', The Journal of the Royal Anthropological Institute of Great Britain and Ireland, vol. 82, no. 1, pp. 71-88, doi: 10.2307/2844041

Gowda, KC 1991, 'The dynamics of bhūța worship', in Editorial committee (ed.), Perspectives on Dakshina Kannada and Kodagu: Mangalore University decennial volume, Mangalore University, Mangalagangothri, pp. 11-21.

Gowda, KC2005, Themaskand themessage, Madipu Prakashana, Mangalagangothri.

Graeber, D 2015, 'Radical alterity is just another way of saying "reality": A reply to Eduardo Viveiros de Castro', HAU: Journal of Ethnographic Theory, vol. 5, no. 2, pp. 1-41, doi: 10.14318/hau5.2.003

Guha, R 2000, The unquiet woods: Ecological change and peasant resistance in the Himalaya (expanded edn.), University of California Press, Berkeley.

Harper, EB 1964, 'Ritual pollution as an integrator of caste and religion', The Journal of Asian Studies, vol. 23, pp. 151-197, doi: 10.2307/2050627

Henare, A 2007, 'Taonga Mäori: Encompassing rights and property in New Zealand', in A Henare, M Holbraad \& S Wastell (eds.), Thinking through things: Theorising artefacts ethnographically, Routledge, New York, pp. 47-67, doi: 10.1558/ fiel2008v2i2.187

Henare, A, Holbraad, M \& Wastell, S 2007, 'Introduction: Thinking through things', in A Henare, M Holbraad \& S Wastell (eds.), Thinking through things: Theorising artefacts ethnographically, Routledge, New York, pp. 1-31, doi: 10.1111/j. 1467-9655.2010.01661_3.x

Hirose, K 1997, 'Fune naki kouseki to shiteno sei: Merleau-Ponty ni okeru seimeikagaku’, Gengobunkaronshū, vol. 45, pp. 1-17 (廣瀬浩司「舟なき航跡としての生—— メルロ=ポンティにおける生命科学」『言語文化論集』, vol. 45, pp. 1-17).

Holbraad, M 2007, 'The power of powder: Multiplicity and motion in the divinatory cosmology of Cuban Ifá (or mana, again)', in A Henare, Ma Holbraad, \& S Wastell (eds.), Thinking through things: Theorising artefacts ethnographically, Routledge, New York, pp. 189-225, doi: 10.1558/fiel2008v2i2.187

Holbraad, M 2009, 'Ontography and alterity: Defining anthropological truth', Social Analysis, vol. 53, no. 2, pp. 80-93, doi: 10.3167/sa.2009.530205 
Holbraad, M 2012, Truth in motion: The recursive anthropology of $\mathrm{Cu}$ ban divination, The University of Chicago Press, Chicago, doi: 10.7208/ chicago/9780226349220.001.0001

Holbraad, M \& Pedersen, MA 2017, The ontological turn: An anthropological exposition, Cambridge University Press, Cambridge, doi: 10.1558/jsa.38835

Holbraad, M, Pedersen, MA \& Viveiros de Castro, EV 2014, 'The politics of ontology: Anthropological positions', Theorizing the contemporary, Fieldsights, January 13, viewed 14 October 2014, https://culanth.org/fieldsights/462-the-politics-of-ontologyanthropological-positions

Holbraad, M \& Willerslev, R 2007, 'Transcendental perspectivism: Anonymous viewpoints from Inner Asia', Inner Asia, vol. 9, no. 2, pp. 329-345, doi: 10.1163/ 146481707793646511

Horton, R 1993, Patterns of thought in Africa and the West: Essays on magic, religion and science, Cambridge University Press, Cambridge.

Hosbet, U \& Bhatta, R 2003, The coastal Karnataka industrialisation and its impact on natural resources, paper presented at the Forty-eight public hearing on environment and development, 19 December, Mangalore.

Husserl, E 1973, Zur Phänomenologie der Intersubjektivität: Texte aus dem Nachlass, in I Kern (ed.), M. Nijhoff, The Hague.

Ingold, T 2000, The perception of the environment: Essays on livelihood, dwelling and skill, Routledge, New York.

Ishii, M 2005, 'From wombs to farmland: The transformation of suman shrines in southern Ghana', Journal of Religion in Africa, vol. 35, no. 3, pp. 266-295, doi: $10.1163 / 1570066054782342$

Ishii, M 2007, Seirei tachi no frontia: Ghana nanbu no kaitaku-imin-shakai ni okeru 'choujou-genshou' no minzokushi, Sekaisiso-sha, Kyoto (石井美保『精霊たちのフロ ンティア——ガーナ南部の開拓移民社会における〈超常現象〉の民族誌』世界思想社).

Ishii, M 2012, 'Acting with things: Self-poiesis, actuality, and contingency in the formation of divine worlds', HAU: Journal of Ethnographic Theory, vol. 2, no. 2, pp. 371-388, doi: 10.14318/hau2.2.019

Ishii, M 2013, 'Playing with perspectives: Spirit possession, mimesis, and permeability in the buuta ritual in South India', Journal of the Royal Anthropological Institute, vol. 19, no. 4, pp. 795-812, doi: 10.1111/1467-9655.12065

Ishii, M 2014a, 'The chiasm of machines and spirits: Büta worship, megaindustry, and embodied environment in South India', in G Mohácsi (ed.), Ecologies of care: Innovations through technologies, collectives and the senses (Readings in Multicultural Innovation Volume 4), Osaka University, Osaka, pp. 239-256.

Ishii, M 2014b, 'Traces of reflexive imagination: Matriliny, modern law, and spirit worship in South India', Asian Anthropology, vol. 13, no. 2, pp. 106-123, doi: 10.1080/1683478x.2014.970328

Ishii, M 2015a, 'Wild sacredness and the poiesis of transactional networks: Relational divinity and spirit possession in the büta ritual of South India', Asian Ethnology, vol. 74. no. 1, pp. 87-109, doi: 10.18874/ae.74.1.05

Ishii, M 2015b, 'The ecology of transaction: Dividual persons, spirits, and machinery in a special economic zone in South India,' NatureCulture, vol. 3, pp. 7-34.

Ishii, M 2017, 'Caring for divine infrastructures: Nature and spirits in a special economic zone in India', Ethnos: Journal of Anthropology, vol. 82, no. 4, pp. 690-710, doi: 10.1080/00141844.2015.1107609 
Iyer, KG 1997, 'Tenancy reforms: The field perspective', in A Aziz \& S Krishna (eds.), Land reforms in India vol. 4.: Karnataka: promises kept and missed, Sage Publications, New Delhi, pp. 177-204, doi: 10.1016/s0264-8377(98)00011-8

Jackson, M \& Karp, I 1990, Personhood and agency: The experience of self and other in African cultures, Smithsonian Institution Press, Washington, DC.

Jeffrey, R 2004/2005, 'Legacies of matriliny: The place of women and the "Kerala model"', Pacific Affairs, vol. 77, no. 4, pp. 647-664.

Jensen, CB, Ballestero, A, de la Cadena, M, Fisch, M \& Ishii, M 2017, 'New ontologies? Reflections on some recent "turns" in STS, anthropology and philosophy', Social Anthropology, vol. 25, no. 4, pp. 525-545, doi: 10.1111/1469-8676.12449

Johnson, PC 2011, 'An Atlantic genealogy of "sprit possession"', Comparative Studies in Society and History, vol. 53, no. 2, pp. 393-425.

Kamath, SU (ed.) 1982, Gazetteer of India: Karnataka State: Karnataka State gazetteer Part 1, Government of Karnataka Publication, Bangalore.

Kapferer, B 1979, 'Mind, self, and other in demonic illness: The negation and reconstruction of Self', American Ethnologist, vol. 6, no. 1, pp. 110-133, doi: 10.1525/ ae.1979.6.1.02a00080

Kapferer, B 1991, A celebration of demons: Exorcism and the aesthetics of healing in Sri Lanka, 2nd edn., Smithsonian Institution Press, Washington, DC, doi: 10.1525/ae.1985.12.1.02a00330

Kapferer, B 2003, 'Introduction: Outside all reason: Magic, sorcery and epistemology in anthropology', in B Kapferer (ed.), Beyond rationalism: Rethinking magic, witchcraft and sorcery, Berghahn, New York, pp. 1-30, doi: $10.3167 / 015597702782409310$

Karashima, N 1994, 'Vijayanagara oukoku no houken shihai', in N Karashima (ed.), Indo-nyūmon II Dravida no sekai, Tokyo Daigaku Shuppankai, Tokyo, pp. 166-178 (辛島昇「ヴイジャヤナガル王国の封建支配」辛島昇編『インド入門 II ドラ ヴィダの世界』、pp. 166-178、東京大学出版会).

Kawamoto, H 2006, Sisutemu genshougaku: Ōtopoiesis no daiyon-ryouiki, Sin-sha, Tokyo (河本英夫『システム現象学——オートポイエーシスの第四領域』新曜社).

Keller, M 2002, The hammer and the flute: Women, power, and spirit possession, The Johns Hopkins University Press, Baltimore, MD.

Kimura, B 1997, 'Rialiti to aktualiti: Rjinshou sairon', in Y Nakamura \& B Kimura (eds.), Kouza seimei '97 vol. 2., pp. 75-110, Tetsugaku Shobo, Tokyo (木村敏「リ アリティとアクチュアリティ一一離人症再論」中村雄二郎・木村敏監修『講座 生命’97 vol. 2』、pp. 75-110、哲学書房).

Kimura, B 2000, Guzensei no seishin byouri, Iwanami Shoten, Tokyo (木村敏『偶然 性の精神病理』岩波書店).

Kimura, B 2005, Kankei to shite no jiko, Misuzu Shobo, Tokyo (木村敏『関係として の自己』みすず書房).

Kimura, B 2010, 'Yakusha kaisetsu', in V von Weizsäcker, Pathosophie, trans. B Kimura, Misuzu Shobo, Tokyo, pp. 550-567 (木村敏「訳者解説」ヴィクトーア・フォン・ ヴァイツゼカー『パトゾフィー』、pp. 550-567、みすず書房).

Kimura, S 2016, 'When a seawall is visible: Infrastructure and obstruction in post-tsunami reconstruction in Japan', Science as Culture, vol. 25, no. 1, pp. 2343, doi: 10.1080/09505431.2015.1081501

Kohn, E 2007, How dogs dream: Amazonian natures and the politics of transspecies engagement', American Ethnologist, vol. 34, no. 1, pp. 3-24, doi: 10.1525/ ae.2007.34.1.3 


\section{Bibliography}

Kohn, E 2013, How forests think: Toward an anthropology beyond the human, University of California Press, Berkeley, doi: 10.19181/socjour.2015.21.2.1327

Kohn, E 2015, 'Anthropology of ontologies', Annual Review of Anthropology, vol. 44, pp. 311-327.

Kramer, F 1993, The red fez: Art and spirit possession in Africa, trans. MR Green, Verso, London.

Laidlaw, J 2000, 'A free gift makes no friends', The Journal of the Royal Anthropological Institute, vol. 6, no. 4, pp. 617-634, doi: 10.1111/1467-9655.00036

Laidlaw, J 2012, 'Ontologically challenged', Anthropology of this Century, no. 4, viewed 8 August 2016, http://aotcpress.com/articles/ontologically-challenged/

Lambek, M 1993, Knowledge and practice in Mayotte: Local discourses of Islam, sorcery, and spirit possession, University of Toronto Press, Toronto, doi: $10.3138 / 9781442676534$

Lambek, M \& Strathern, A 1998, Bodies and persons: Comparative perspectives from Africa and Melanesia, Cambridge University Press, Cambridge, doi: 10.1017/ cbo9780511802782

Latour, B 1993, We have never been modern, trans. C Porter, Harvester Wheatsheaf, London.

Levien, M 2011, 'Special economic zones and accumulation by dispossession in India', Journal of Agrarian Change, vol. 11, no. 4, pp. 454-483, doi: 10.1111/j. 1471-0366.2011.00329.x

Lienhardt, G 1961, Divinity and experience: The religion of the Dinka, Clarendon Press, Oxford.

Maclean, CD 1877, Standing information regarding the official administration of the Madras Presidency, E. Keys, at the Government Press, Madras.

Maclean, CD (ed.) 1987(1885), Maclean's manual of the administration of the Madras Presidency, Vol. 1, Asian Educational Service, New Delhi.

Maclean, CD 1989(1885), Maclean's manual of the administration of the Madras Presidency, Vol. 2, Asian Educational Service, New Delhi.

MacPherson, CB 1964, The political theory of possessive individualism: Hobbes to Locke, Oxford University Press, Oxford, doi: 10.1093/oxfordhb/9780198717133.013.42

Madhava, KGV 1984, 'Genesis of agrarian relations in the coastal Karnataka: Some historical evidences', in AR Rajapurohit (ed.), Land reforms in India. Ashish Publishing House, New Delhi, pp. 1-13.

Madhava, KGV 1985, Religions in coastal Karnataka 1500-1763, Inter-India Publications, New Delhi.

Marriott, M 1976, 'Hindu transactions: Diversity without dualism', in B Kapferer (ed.), Transaction and meaning: Directions in the anthropology of exchange and symbolic behaviour, Institute for the Study of Human Issues, Philadelphia, pp. 109-142.

Marriott, M \& Inden, RB 1977, 'Toward an ethnosociology of South Asian caste systems', in K David (ed.), The new wind: Changing identities in South Asia, Mouton Publishers, The Hague, pp. 227-238, doi: 0.1515/9783110807752.227

Masquelier, A 2002, 'Road mythographies: Space, mobility, and the historical imagination in postcolonial Niger', American Ethnologist, vol. 29, no. 4, pp. 829-856, doi: 10.1525/ae.2002.29.4.829

Mauss, M 1990(1950), The gift: The form and reason for exchange in archaic societies, trans. WD Halls, W. W. Norton, New York and London.

Mead, GH 1927, 'The objective reality of perspectives', in ES Brightman (ed.), Proceedings of the sixth international congress of philosophy, Longmans, Green and Co, New York, pp. 75-85, doi: 10.5840/wcp6192726 
Mead, GH 1962(1934), Mind, self, and society: From the standpoint of a social behaviourist, in CW Morris (ed.), The University of Chicago Press, Chicago, IL.

Menon, DP 1993, 'The moral community of the teyyattam: Popular culture in late colonial Malabar', Studies in History, vol. 9, no. 2, pp. 187-217, doi: $10.1177 / 025764309300900203$

Merleau-Ponty, M 2012(1945), Phenomenology of perception, trans. DA Landes, Routledge, London.

Meyer, B 1999, 'Commodities and the power of prayer: Pentecostalist attitudes towards consumption in contemporary Ghana', in B Meyer \& P Geschiere (eds.), Globalization and identity: Dialectics of flow and closure, Blackwell Publishers, Oxford, pp. 151-176, doi: 10.3917/polaf.078.0191

Mines, M 1988, 'Conceptualizing the person: Hierarchical society and individual autonomy in India', American Anthropologist, vol. 90, no. 3, pp. 568-579, doi: 10.1525/aa.1988.90.3.02a00030

Mines, M 1994, Public faces, private voices: Community and individuality in South India, University of California Press, Berkeley.

Mizushima, T 1999, 'Kūkan no seppen', in T Sugishima (ed.), Tochi shoyū no seijishi: Jinruigakuteki shiten, Fukyo-sha, Tokyo, pp. 443-456 (水島司「空間の切片」杉 島敬志編『土地所有の政治史一一人類学的視点』、pp. 443-456、風響社).

Monier-Williams, M 2008(1899), A Sanskrit-English dictionary: Etymologically and philologically arranged: with special reference to cognate Indo-European languages, Asian Educational Services, New Delhi and Chennai, doi: 10.2307/287725

Moore, HL \& Sanders, T 2001, 'Magical interpretations and material realities: An introduction', in HL Moore \& T Sanders (eds.), Magical Interpretations, material realities: Modernity, witchcraft and the occult in postcolonial Africa, Routledge, London, pp. 1-27, doi: 10.4324/9780203398258

Moore, MA 1985, 'A new look at the Nayar taravad', Man, vol. 20, no. 3, pp. $523-$ 541, doi: $10.2307 / 2802444$

Mosko, M 2010, 'Partible penitents: Dividual personhood and Christian practice in Melanesia and the West', The Journal of the Royal Anthropological Institute, vol. 16, no. 2, pp. 215-240, doi: 10.1111/j.1467-9655.2010.01618.x

Mukherjee, N 1962, The ryotwari system in Madras 1792-1827, Progressive Publishers, Calcutta.

Munn, ND 1996, 'Excluded spaces: The figure in the Australian aboriginal landscape', Critical Inquiry, vol. 22, no. 3, pp. 446-465, doi: 10.1086/448801

Nausner, B 2008, Human experience and the triune God: A theological exploration of the relevance of human experience for Trinitarian theology, Peter Lang, Bern.

Navada, AV \& Fernandes, D (eds.) 2008, The devil worship of the Tuluvas: From the papers of late A. C. Burnell, Karnataka Tulu Sahitya Academy, Mangalore.

Ota, N 1994, 'Igirisu jin no mita minami indo sonraku: Chizeiseido no dounyū wo megutte', in N Karashima (ed.), Indo-nyūmon II Dravida no sekai, Tokyo Daigaku Shuppankai, Tokyo, pp. 222-233 (太田信宏「イギリス人の見た南インド村落——地 税制度の導入をめぐって」辛島昇編『インド入門II ドラヴィダの世界』、pp. 222-233、 東京大学出版会).

Ong, A 1988, 'The production of possession: Spirits and the multinational corporation in Malaysia', American Ethnologist, vol. 15, no. 1, pp. 28-42, doi: 10.1525/ ae.1988.15.1.02a000030

Osella, F \& Osella, C 1996, 'Articulation of physical and social bodies in Kerala', Contributions to Indian Sociology, vol. 30, no. 1, pp. 37-68, doi: 10.1177/006996679603000102 
Padmanabha, P 1976, Census of India, 1971: Special study report on bhuta cult in South Kanara district, Controller of Publications, Delhi.

Pani, N 1984, 'Reforms to pre-empt change: Land legislation in Karnataka', in AR Rajapurohit (ed.), Land reforms in India, Ashish Publishing House, New Delhi, pp. 42-73, doi: $10.2307 / 3516835$

Parry, J 1986, 'The gift, the Indian gift and the "Indian gift", Man, vol. 21, no. 3, pp. 453-473, doi: $10.2307 / 2803096$

Parry, J 1989, 'On the moral perils of exchange', in J Parry \& M Bloch (eds.), Money and the morality of exchange, Cambridge University Press, Cambridge, pp. 64-93, doi: 10.1017/cbo9780511621659.003

Parry, J 1994, Death in Banaras, Cambridge University Press, Cambridge.

Parry, J 2015, 'The sacrifices of modernity in a Soviet-built steel town in central India', Anthropology of this Century, no. 12, viewed 14 October 2016, http:// aotcpress.com/articles/sacrifices/

Pedersen, MA 2001, 'Totemism, animism and North Asian indigenous ontologies', The Journal of the Royal Anthropological Institute, vol. 7, no. 3, pp. 411-427, doi: 10.1111/1467-9655.00070

Pedersen, MA 2011, Not quite shamans: Spirit worlds and political lives in Northern Mongolia, Cornell University Press, New York, doi: 10.7591/9780801460937

Pedersen, MA, Empson, R, \& Humphrey, C (eds.) 2007, 'Special issue on perspectivism', Inner Asia, vol. 9, no. 2, pp. 141-345.

Pels, P 2003, 'Introduction: Magic and modernity', in B Meyer \& P Pels (eds.), Magic and modernity: Interfaces of revelation and concealment, Stanford University Press, Stanford, CA, pp. 1-38.

Piaget, J 1954, The construction of reality in the child, trans. M Cook, Basic Books, New York.

Pinney, C 2001, 'Piercing the skin of the idol', in C Pinney \& N Thomas (eds.), Beyond aesthetics: Art and the technologies of enchantment, Berg, Oxford, pp. 157-179.

Presler, FA 1987, Religion under bureaucracy: Policy and administration for Hindu temples in South India, Cambridge University Press, Cambridge, doi: 10.1017/ cbo9780511557729.001

Raheja, GG 1988, The poison in the gift: Ritual, prestation, and the dominant caste in a North Indian village, The University of Chicago Press, Chicago, IL doi: 10.7202/015148ar

Rajan, MAS 1984, 'Working of the land tribunals of India', in AR Rajapurohit (ed.), Land reforms in India, Ashish Publishing House, New Delhi, pp. 139-163.

Rajan, MAS 1986, Land reforms in Karnataka: An account by a participant observer, Hindustan Publishing Corporation, Delhi.

Ramesh, KV 1970, A history of South Kanara: From the earliest times to the fall of Vijayanagara, Research Publications Series 12, Karnatak University, Dharwar, doi: $10.1017 / \mathrm{s} 0041977 \times 00120890$

Ranger, T 2007, 'Scotland Yard in the bush: Medicine murders, child witches and the construction of the occult: a literature review', Africa, vol. 77, no. 2, pp. 272283, doi: 10.3366/afr.2007.77.2.272

Rao, BS 1991, 'South Kanara in the 19th century: Contradictions in the colonial discourse', in Editorial Committee (eds.), Perspectives on Dakshina Kannada and Kodagu. Mangalore University, Mangalagangotri, pp. 64-72.

Rao, GK 1898, A treatise on Aliya Santana law and usage, The Codialbail Press, Mangalore. 
Rasmussen, S 2008, 'Personhood, self, difference, and dialogue (commentary on Chaudhary)', International Journal for Dialogical Science, vol. 3, no. 1, pp. 31-54.

Rosenthal, J 1998, Possession, ecstasy, and law in Ewe voodoo, University Press of Virginia, Charlottesville.

Sakabe, M 1999, 'Modoki: The mimetic tradition in Japan', trans. M Marra, in M Marra (ed.), Modern Japanese aesthetics: A reader, University of Hawai i Press, Honolulu, pp. 251-262.

Sanders, T 2008, 'Buses in Bongoland: Seductive analytics and the occult', Anthropological Theory, vol. 8, no. 2, pp. 107-132, doi: 10.1177/1463499608090787

Santo, DE 2012, 'Imagination, sensation and the education of attention among Cuban spirit mediums', Ethnos: Journal of Anthropology, vol. 77, no. 2, pp. 252-271, doi: 10.1080/00141844.2011.600832

Sax, WS 2002, Dancing the self: Personhood and performance in the pāndav līlā of Garhwal, Oxford University Press, New York, doi: 10.1017/s0021911804001469

Schütz, A 1970, On phenomenology and social relations: Selected writings, in HR Wagner (ed.), The University of Chicago Press, Chicago.

Sekine, Y 2002, Anthropology of untouchability: 'Impurity' and 'pollution' in a South Indian society, National Museum of Ethnology, Osaka.

Shah, A 2010, In the shadows of the state: Indigenous politics, envilonmentalism, and insurgency in Jharkhand, India, Duke University Press, Durham, NC, doi: 10.1111/ aman.12059_33

Sharma, NK 2009, 'Special economic zones: Socio-economic implications', Economic \& Political Weekly, vol. XLIV, no. 20, pp. 18-21.

Shiva, V 1988, Staying alive: Women, ecology, and survival in India, Zed Books, London.

Singh, KS 2002(1993), The scheduled castes (revised edn.), Oxford University Press, New Delhi.

Smith, FM 2006, The self possessed: Deity and spirit possession in South Asian literature and civilization, Columbia University Press, New York, doi: 10.7312/smit 13748-toc

Smith, K 2012, 'From dividual and individual selves to porous subjects', The Australian Journal of Anthropology, vol. 23, no. 1, pp. 50-64, doi: 10.1111/j.17576547.2012.00167.x

Sontheimer, GD 1965, 'Religious endowments in India: The juristic personality of Hindu deities', Zeitschrift für vergleichende Rechtswissenschaft, vol. 67, pp. 45-100.

Sperber, D 1982, Le savoir des anthropologues, Hermann, Paris.

Srinivas, MN 1952, Religion and society among the Coorgs of South India, The Clarendon Press, Oxford.

Stambach, A 2000, 'The rationality debate revisited', Reviews in Anthropology, vol. 28, no. 4, pp. 341-351, doi: 10.1080/00988157.2000.9978240

Stein, B 1983, 'Idiom and ideology in early nineteenth-century South India', in P Robb (ed.), Rural India: Land, power and society under British rule, Curzon Press, London, pp. 23-58.

Stein, B 1989, Thomas Munro: The origins of the colonial state and his vision of empire, Oxford University Press, Delhi.

Stoffle, RW \& Arnold, R 2003, 'Confronting the angry rock: American Indians' situated risks from radioactivity', Ethnos, vol. 68, no. 2, pp. 230-248, doi: 10.1080/0014184032000097768

Stoller, P 1995, Embodying colonial memories: Spirit possession, power, and the Hauka in West Africa, Routledge, New York, doi: 10.4324/9781315021669 
Strathern, M 1988, The gender of the gift: Problems with women and problems with society in Melanesia, University of California Press, Berkeley.

Strathern, M 1996, 'Cutting the network', The Journal of the Royal Anthropological Institute, vol. 2, no. 3, pp. 517-535.

Sturrock, J 1894, Madras district manuals: South Canara, vol. 1, The Superintendent, Government Press, Madras.

Swain, A 1997, 'Democratic consolidation? Environmental movements in India', Asian Survey, vol. 37, no. 9, pp. 818-832, doi: 10.1525/as.1997.37.9.01p02775

Swancutt, K 2007, 'The ontological spiral: Virtuosity and transparency in Mongolian games', Inner Asia, vol. 9, no. 2, pp. 237-259, doi: 10.1163/146481707793646520

Tambiah, SJ 1990, Magic, science, religion, and the scope of rationality, Cambridge University Press, Cambridge.

Tanabe, A 2006, 'Recast(e)ing identity: Transformation of inter-caste relationships in post-colonial rural Orissa', Modern Asian Studies, vol. 40, no. 3, pp. 761-796, doi: 10.1017/s0026749x06002022

Tanaka, M 1997, Patrons, devotees and goddesses: Ritual and power among the Tamil fishermen of Sri Lanka, Manohar, New Delhi, doi: 10.2307/2803585

Taussig, M 1980, The devil and commodity fetishism in South America, The University of North Carolina Press, Chapel Hill, NC.

Taussig, M 1993, Mimesis and alterity: A particular history of the senses, Routledge, New York.

Taylor, AC 1996, 'The soul's body and its states: An Amazonian perspective on the nature of being human', Journal of the Royal Anthropological Institute, vol. 2, no. 2, pp. 201-215, doi: 10.2307/3034092

Thimmaiah, G \& Aziz, A 1983, 'The political economy of land reforms in Karnataka, A South Indian State', Asian Survey, vol. 23, no. 7, pp. 810-829, doi: 10.1525/ as.1983.23.7.01p00656

Thimmaiah, G \& Aziz, A 1984a, 'The political economy of land reforms in India', in AR Rajapurohit (ed.), Land reforms in India, Ashish Publishing House, New Delhi, pp. 18-37.

Thimmaiah, G \& Aziz, A 1984b, The political economy of land reforms, Ashish Publishing House, New Delhi.

Thurston, E 1975(1909a), Castes and tribes of Southern India, vol. I, Cosmo Publications, Delhi.

Thurston, E 1975(1909b), Castes and tribes of Southern India, vol. IV, Cosmo Publications, Delhi.

Thurston, E 1975(1909c), Castes and tribes of Southern India, vol. V, Cosmo Publications, Delhi.

Thurston, E 1975(1909d), Castes and tribes of Southern India, vol. VI, Cosmo Publications, Delhi.

Turner, T 1995, 'Social body and embodied subject: Bodiliness, subjectivity, and sociality among the Kayapo', Cultural Anthropology, vol. 10, no. 2, pp. 143-170, doi: 10.1525/can.1995.10.2.02a00010

Turner, T 2009, 'The crisis of late structuralism. Perspectivism and animism: Rethinking culture, nature, spirit, and bodiliness', Tipiti: Journal of the Society for the Anthropology of Lowland South America, vol. 7, no. 1, 3-42, viewed 14 October 2016, http://digitalcommons.trinity.edu./tipiti/vol7/iss1/1

Uchiyamada, Y 1999, 'Soil, self, resistance: Late-modernity and locative spirit possession in Kerala', in J Assayag \& G Tarabout (eds.), La possession en Asie du 
sud: Parole, corps, territoire. École des Hautes Études en Sciences Sociales, Paris, pp. 289-311, doi: 10.7202/012624ar

Uchiyamada, Y 2000, 'Passions in the landscape: Ancestor spirits and land reforms in Kerala, India', South Asia Research, vol. 20, no. 1, pp. 63-84, doi: 10.1177/ 026272800002000104

Učida, N \& Rajapurohit, BB 2013, Kannada-English etymological dictionary, Tokyo University of Foreign Studies, Tokyo.

Upadhyaya, UP 1996, 'Bhuta worship', in UP Upadhyaya (ed.), Coastal Karnataka: Studies in folkloristic and linguistic traditions of Dakshina Kannada region of the western coast of India, Rashtrakavi Govind Pai Samshodhana Kendra, Udupi, pp. 197-228.

Upadhyaya, UP (ed.) 1988-1997, Tulu lexicon, Vol. 1-6, Rashtrakavi Govind Pai Samshodhana Kendra, Udupi.

Venkatesan, S (ed.) 2010, 'Ontology is just another word for culture: Motion tabled at the 2008 meeting of the group for debates in anthropological theory, University of Manchester', Critique of Anthropology, vol. 30, no. 2, pp. 152-200, doi: $10.1177 / 0308275 \times 09364070$

Vigh, HE \& Sausdal, DB 2014, 'From essence back to existence: Anthropology beyond the ontological turn', Anthropological Theory, vol. 14, no. 1, pp. 49-73, doi: $10.1177 / 1463499614524401$

Vijayabaskar, M 2010, 'Saving agricultural labour from agriculture: SEZs and politics of silence in Tamil Nadu', Economic \& Political Weekly, vol. XLV, no. 6, pp. 36-43.

Vilaça, A, 2005, 'Chronically unstable bodies: Reflections on Amazonian corporalities', Journal of the Royal Anthropological Institute, vol. 11, no. 3, pp. 445-464, doi: 10.1111/j.1467-9655.2005.00245.x

Viveiros de Castro, E 1998, 'Cosmological deixis and Amerindian perspectivism', The Journal of the Royal Anthropological Institute, vol. 4, no. 3, pp. 469-488, doi: $10.2307 / 3034157$

Viveiros de Castro, E 2003. 'And', after-dinner speech given at Anthropology and Science, the 5th Decennial Conference of the Association of Social Anthropologists of Great Britain and Commonwealth, 14 July 2003, Manchester Papers in Social Anthropology, viewed 14 October 2016, https://sites.google.com/a/abaetenet.net/ nansi/abaetextos/anthropology-and-science-e-viveiros-de-castro

Viveiros de Castro, E 2004a, 'Perspectival anthropology and the method of controlled equivocation', Tipiti: Journal of the Society for the Anthropology of Lowland South America, vol. 2, no. 1, pp. 3-22.

Viveiros de Castro, E 2004b, 'Exchanging perspectives: The transformation of objects into subjects in Amerindian ontologies', Common Knowledge, vol. 10, no. 3, pp. 463-484, doi: 10.1215/0961754x-10-3-463

Viveiros de Castro, E 2011a, 'Zeno and the art of anthropology: Of lies, beliefs, paradoxes, and other truths', Common Knowledge, vol. 17, no. 1, pp. 128-145, doi: $10.1215 / 0961754 \mathrm{x}-2010-045$

Viveiros de Castro, E 2011b, The inconstancy of the Indian soul: The encounter of Catholics and cannibals in 16th-century Brazil, trans. GD Morton, Prickly Paradigm Press, Chicago, IL.

Viveiros de Castro, E 2013(2002), 'The relative native', trans. J Sauma, M Holbraad, HAU: Journal of Ethnographic Theory, vol. 3, no. 3, pp. 473-502, doi: 10.14318/ hau3.3.032 
Viveiros de Castro, E 2014a, 'Who is afraid of the ontological wolf? Some comments on an ongoing anthropological debate', CUSAS Annual Marilyn Strathern Lecture, 30 May 2014, viewed 14 October 2016, https://sisu.ut.ee/sites/default/files/ biosemio/files/cusas_strathern_lecture_2014.pdf

Viveiros de Castro, E 2014b, Cannibal metaphysics: For a post-structural anthropology, P Skafish (trans. and ed.), Univocal Publishing, Minneapolis, MN.

von Uexküll, J 1921, Umwelt und Innenwelt der Tiere, Verlag von Julius Springer, Berlin, doi: 10.1007/978-3-662-24819-5_20

von Weizsäcker, V 1946, Anonyma, Verlag A. Francke AG, Bern.

von Weizsäcker, V 1997(1950), Der Gestaltkreis: Theorie der Einheit von Wahrnehmen und Bewegen, Gesammelte Schriften 4, D Janz, W Rimpau \& W Schindler (eds.), Suhrkamp Verlag, Frankfurt am Main.

von Weizsäcker, V 2005, Pathosophie, Gesammelte Schriften 10, W Schindler, D Janz \& P Achilles (eds.), Suhrkamp Verlag, Frankfurt am Main.

Wadley, S 1977, 'Power in Hindu ideology and practice', in K David (ed.), The new wind: Changing identities in South Asia, Mouton Publishers, The Hague, pp. 133157, doi: 10.1515/978311087752.133

Warnier, JP 1995, 'Around plantation: The ethnography of business in Cameroon', in D Miller (ed.), Worlds apart: Modernity through the prism of the local, Routledge, London, pp. 91-109.

White, EJB 2015, Beyond empire: Vijayanagara imperialism and the emergence of the Keladi-Ikkeri Nayaka state, 1499-1763 C.E., A dissertation submitted in partial fulfillment of the requirements for the degree of Doctor of Philosophy (Anthropology) in The University of Michigan, viewed 23 September 2019, https://deepblue. lib.umich.edu/handle/2027.42/111540

Willerslev, R 2004, 'Not animal, not not-animal: Hunting, imitation and empathetic knowledge among the Siberian Yukaghirs', The Journal of the Royal Anthropological Institute, vol. 10, no. 3, pp. 629-652, doi: 10.1111/j.1467-9655.2004.00205.x

Willerslev, R 2007, Soul hunters: Hunting, animism, and personhood among the Siberian Yukaghirs, University of California Press, Berkeley, doi: 10.1111/j.15481425.2008.00127.x

Wilson, BR (ed.) 1974, Rationality, Basil Blackwell, Oxford.

\section{Newspaper articles and websites}

Daijiworld. 2014, July 23. 'Pejawar Swamiji meets Modi, asks not to use agri land for industries', viewed 14 October 2016, www.daijiworld.com/news/news_disp. asp?n_id=250567

Daily News \& Analysis. 2011, May 27. 'Blast at Mangalore SEZ: Korean, two others killed, four injured', viewed 23 August 2014, www.dnaindia.com

Gowda, A 2011, July 16. 'Yedurappa relies on seers to clear land deals in Karnataka', Indiatoday, viewed 14 October 2016, http://indiatoday.intoday.in/story/ yeddyurappa-relies-on-seers-to-clear-land-deals/1/145068.html

Shenoy, J 2011, May 27. 'The accident occurred at Mangalore site of ISPRL', The Times of India, viewed 23 August 2014, http://timesofindia.indiatimes.com

The Canara Times. 2009, March 1-15. 'Kalavar's Guliga daiva refuses to let base for SEZ!'

The Hindu. 2008, January 30. 'Farmers stage rally against MSEZ', viewed 14 October 2016, www.thehindu.com/todays-paper/tp-national/tp-karnataka/farmersstage-rally-against-msez/article1189336.ece 
The New Indian Express. 2011, July 12. 'Yedurappa facing heat from religious leaders', viewed 14 October 2016, www.newindianexpress.com/states/karnataka/2011/ jul/12/yeddyurappa-facing-heat-from-religious-leaders-270854.html

\section{Administrative documents}

Couchman, ME 1904, Survey and settlement register of Muduperar village No. 53, Mangalore: Revenue Settlement Office, Mangaluru.

Padu Perar Panchayat Office 2008, House tax record 2007-2008, Padu Perar Panchayat Office, Mangaluru.

Records of Disputes on Law CR No. 7/2002-2003, Deputy Commissioner's Office, Mangaluru.

Villagewar resister of applications filed under section 48-A before the tribunal, Deputy Commissioner's Office, Mangaluru.

\section{Court records (published)}

Kaveri v. Ganga Ratna. 1956, 1 Madras Law Journal, 98.

Munda Chetty v. Thimmaju Hengsu. 1863, 1 Madras High Court Reports, 380.

Sanku v. Puttamma. 1891, Indian Law Reporter 14, Madras, 289.

Santhamma v. Neelamma. 1956, All India Reporter, Madras, 642.

Subba Hegade v. Tongu. 1869, 4 Madras High Court Reports, 196.

Thimmakke v. Akku. 1911. Indian Law Reporter 34, Madras, 481.

\section{Court records (unpublished)}

Lakshminarayana Udpa v. Thyampa Naika and others. The Court of the Subordinate Judge of South Kanara (Original Suit [O.S.] No. 26 of 1932).

Laxmana Chowta v. State of Karnataka and others. The High Court of Karnataka, Bangalore (Writ Petition No. 40504 of 2001).

Laxmana Chowta v. The Deputy Commissioner, Hindu Religious and Charitable Endowments, D. K. Mangalore and Sri Samith Raj. The High Court of Karnataka, Bangalore (Writ Petition No. 18958 of 2007).

Laxminarayana Udupa v. The Commissioner for Religious and Charitable Endowments in Mysore at Bangalore and others. The Court of the Subordinate Judge of Mangalore, South Kanara (O.S. No.25 of 1960). 

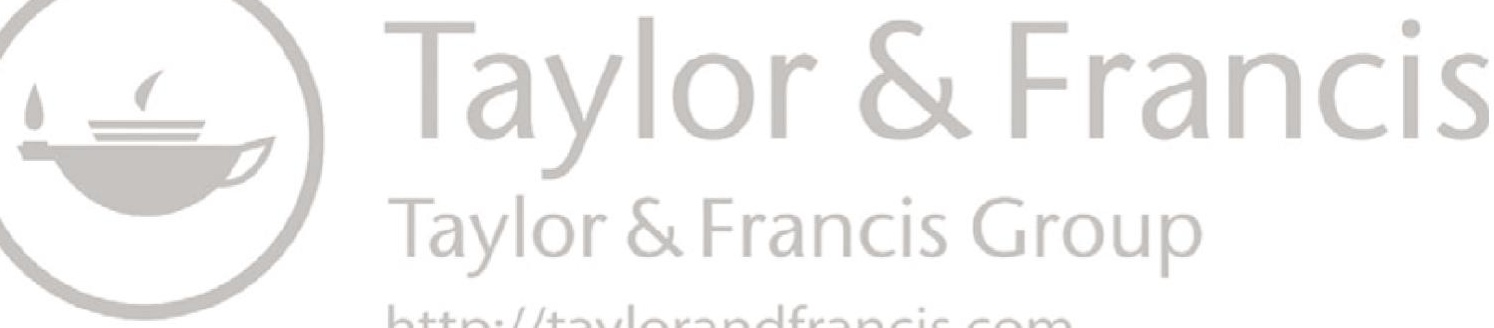

http://taylorandfrancis.com 


\section{Index}

Note: Bold page numbers refer to tables; italic page numbers refer to figures and page numbers followed by " $n$ " denote endnotes.

abhișeka (consecration rituals) 90; pañcāmṛta 46

Abhishankar, K. 143, 206n1

Ācāri 39

actuality $14,3 \ln 27$

adikāra 54; in industry, undertaking 243-4

administrative system, in Vijayanagara period $138-41$

agency of deities and power of modern law, conflict between 131-3

Alake guttu families and deities, pāḍdana on $67-8$

Ali, Hyder 142, 161n6 aliiyasantāna kaț̣u (aḷiyakatțụ) 24, 27, 32n30, 38, 67, 135, 154, 169, 171-4, $180,181 \mathrm{n} 5,255$; and modern law, encounter between $164-8$

Aliyasantana family $166-8,181 \mathrm{n} 4$

Aliyasantana Law 165-8

Aliyasantana system 165, 168, 170, 171,183

alterity 6-10, 12, 15, 30n19, 49, 249, 250,260

Ālupa period, land tenure in 137

Amerindian ontology 13-14

animism 6, 18, 23, 94, 106n1

Anonyma (von Weizsäcker) 18

antidevelopment movement, led by local magnate and village deity 213-14

Appadurai, A. 23-4, 26, 83, 111, 113, $114,131,133 \mathrm{n} 1,133 \mathrm{n} 7$

Arasu (ullāalụ) 48-51, 57, 58n1, 58n8, 60, 65-7, 70, 76, 78, 89, 99, 115, 140, 152; Balavāndị's acquisition of a brammalinga 64-5; Balavāṇụi's invitation to 63; and four guttu heads
62-3; gaggara decci 72-3; nēma decci 73-4; visits, Balavāṇụi's and 63-4

Arbuthnot, A. J. 142-5, 148

'Aré'aré ethnography 84-5

Arnold, D. 32n 32

Asad, T. 30n16

astrological oracle 128-31

astrology (aștamañgala praśne) 46

Avargal, B.G. 116

Aziz, A., 155, 156, 163n31

Babadzan, A. 114

Baden-Powell, B.H. 162n17

Bahujan Samaj Party (BSP) 215, 234n3

bailụ 41

bākimārụ 43, 47n17

Balavānudi 36, 37, 45, 48-57, 58n8, 59n11, $60,62,66,68,70-80,81 \mathrm{n} 3,89-92,99$, 102, 115, 116, 122, 135, 140, 202, 203; acquisition of a brammalinga $64-5$; and Arasu visits 63-4; and Bramma, interaction between 90-2; fight with Bramma 75-6; gaggara dippuni 74-5; invitation to Arasu 63; in Perar 50

Bale Semita 64-6

bāḷ 137

Banța 38-9, 52; landlord households, families of 189; landlords, types of $\mathbf{1 8 6}$

Baṇtakamba 48-9; ritual for 77-8

Banța landlords 27, 149, 16n1, 164, 183, 209, 225; land holdings and acquisitions by, households 189-91, 190; inheritance from father to son 192-4; traditional family land and 'grandfather's land', inheritance of $\mathbf{1 8 9}, \mathbf{1 9 1 - 2}$; types of $\mathbf{1 8 6}$

Bārakūru rājya 137 
bari 38

bārne 78

batțalụ kānịke kambulạ ritual see

kambuḷa ritual

Battle of Rakkasa-Tañgaḍi (1565) 136

Batțrụ/Brahman 40

Bavano 99

Bedi, H.P. 210

Behrend, H. 30n7

being/existence $10-15,18,19,31 \mathrm{n} 23$, 248-52; encounter inquiries 20-2; potential for transformation 19-20; temporality of 19-20

Bengali zamindari system 144-5, 162n14

Benjamin, W. 95

Bergson, H. 14, 15, 30n18

Bharatiya Janata Party (BJP) 215, 235n4

Bhat, M.V.S. 165, 181n9, 181n11

Bhat, N.S. 149, 162n16, 206n1

Bhatt, P.G. 146, 161n4

bhukti samudāya 137

Bhuthala Pandya (Jaya Pandya) 166, 180n1

Bhuthala Pandya's Kattu Kattale 166

Bird-David, N. 32n29, 106n1

BJP see Bharatiya Janata Party (BJP)

Blane, T.L. 150

Blankenburg, W. 106n4, 106n14

blessing 78

Boddy, J. 30n7, 95, 96, 98

bottu 41

Bramma (Bermerụ; Brammabermerụ) 51-2, 91; and Balavāṇdi, interaction between 90-2; battle with Nādu 61-2, 76; fight with (second-half ritual for Balavāndì) 75-6

brammalinga, Balavāṇụi's acquisition of 64-5

Breckenridge. C.A. (1976) 23-4, 26, 83, $133 n 1$

Brückner, H. 31n26

BSP see Bahujan Samaj Party (BSP)

Busby, C. 32n28, 93n1

būta dancer, dilemma of 126-7

būtas: owners of the land 45-6; curse over transfer of land rights, fear of 202-4; in the midst of development project 209-35; and villagers, transactional network between 87

būta śakti 1-2, 31n27

būta worship 1, 20, 25, 26, 28, 37, 39, 40, 46n $3,50,68,79,80,82,83,85$, 88-90, 92, 94, 99, 106n6, 109, 110, $112,113,121,135,164,169,173$,
174, 176, 180, 202, 203, 209, 217 , 219, 220, 224, 227, 230-4, 236, 240 , 243-6, 248, 250-3, 253, 254, 256, 258; agency in conflicts over village shrine 109-34; and granting of land 44-5; people responsible for 52-8, 53; role of 210-11; shrine and deities in Perar 48-9; and social change 24-5; as stronghold of resistance 211-12; under the enactment and amendment of modern law 173-4; in Vijayanagara period 138-41; and villagers, relationships between 23-4

cāla gēṇi 184, 206n1, 206n2, 207n3

Cameroon: modernity of witchcraft 3

Candea, M. 7, 32n29

Carrithers, M. $31 \mathrm{n} 28$

Carse, A. 246n1

Carsten, J. 93n1

cāvaḍi 139

Chitnis, K.N. 162n21

Claus, P.J. 31n26, 58n6

coherence $3 \ln 20$

Collins S. $31 \mathrm{n} 28$

Comaroff, J. 3, 30n7

Comaroff, J.L. 3, 30n7

commensurability $30 \mathrm{n} 17$

Communist Party of India (CPI) 215, $234 n 3$

community of property 169

Congress Party 238

constraints of life $12-15$

contingency of life 12-15

Copeman, J. 32n28, 93n8

coping with modern law 179-80

Coppet, E. de 84, 85

'Cosmological Deixis and Amerindian Perspectivism' (de Castro) 96

Couchman, M.E. 151

CPI see Communist Party of India (CPI) crisis $16-18$

Cuba: divination 12, 31n19; spirit mediumship in $106 \mathrm{n} 8$

cursing goddess 130-1

'Cutting the Network' (Strathern) 84

Dalit 212-16

Damle, C.B. 144, 145, 148, 162n16

Daniel, E.V. 32n28, 93n1

Darhad shamanism 9

deity(ies): and social change 24-5; as a 'sovereign person' $112-15$; as the supreme commander 218-19; waiting for 258-61 
de Laet, M. 246n1

Deleuze, G. 13-15, 30n18

Deleuzian Other 14

democratisation expectation, and shrine development 125-6

Der Gestaltkreis: Theorie der Einheit von Wahrnehmen und Bewegen [The Gestaltkreis: Theory of the unity of perception and movement] (von Weizsäcker) 16

dēśa 139

Descola, P. 106n1

dēva patțe 141

devil worship 2-3

Dirks, N.B. 112, 131, 133n1

disputes over land 224-30

dividuality $82-4$

dividual persons $20,24,26,83-8,170-2$, 254-5

domestic labourer households, group composition of $\mathbf{1 8 8}, 189$

domestic labourers (kāli okkelụ) 184

Dugganna Baidya 64

Dumont, L. 32n28, 91, 93n9

Durgā 126, 130, 134n15

Eck, D.L. 114

Empson, R. 106n5

Englund, H. 30n9

enne detonuni 74

essentialism: radical 5, 7, 14, 250;

strategic 10

ethnography 11

Euro-American 6, 8

Europe: spirit possession 4

exchange value 4

Fabian, J. 30n8

Fourth Battle of Mysore (1799) 142

Freeman, R. 32n 28

Fuller, C.J. 90, 93n9, 93n12, 112, 114, $133 n 1,133 n 2,133 n 7$

Gad, C. 7, 30n 10

Gadgil, M. 32n32

gaḍipatinārụ 53-7, 59n11, 68, 71-4, 79,

$88,104,119,121,122,124-7,149$,

$203,220,239,242,244,246,252,253$, 259,260

gaggara decci (first-half ritual to Arasu) $72-3$

gaggara dīpuni (first-half ritual for

Balavāṇụi) 74-5

gandha 103-4
Gangādara Rai 53-4, 69n1, 119, 120, $125,126,129$

Gell, A. 30n11, 110, 112-15, 133n6

Gellner, E. 30n16

Gender of the Gift, The (Strathern) 84

gēni 137

Geschiere, P. 3, 30n8

Gestaltkreis theory 16-17, 19-20, 22, 23

Gift, The (Mauss) 93n3

gift-exchange 23, 93n 8

globalisation 5

God Bala Madi Temple 152

Gowda, K.C. 28-9, 138-40

Graeber, D. 13

grāma 139

'grandfather's land', inheritance of 174, 191-2

group composition: of domestic labourer households 188, 189; of landlord households 188, 188, 189; of other households 188, 189; of tenant households 188, 189

guḍḍ $42-4,66,86-8$

Guha, R. 32n32

Gundya's Janana 62

Harper, E.B. 93n9

Harris, T. 150

Henare, A. 12, 30n11, 30n17

Hindu Religious Endowments Board (HRE Board) see 'Madras Hindu Religious Endowments Act (Madras Act II of 1927, HRE Act)'

Hindu Religious Institutions and Charitable Endowments Act, 1997 $119,133 \mathrm{n} 13$

Hindu Succession Act, 1956 (Act No. 30 of 1956) $165,174,181 \mathrm{n} 9,207 \mathrm{n} 11$

Hindu temples, historical transformation of $111-12$

'Hindu Transactions: Diversity without Dualism' (Marriott) 82-3

Hirose, K. $3 \ln 24$

Holbraad, M. 12, 30n11, 30-1n19, 106n6

Horton, R. 30n13

HRE see Hindu Religious Endowments Board (HRE Board); Madras Hindu Religious Endowments Act (Madras Act II of 1927, HRE Act)

human-nonhuman relations 23, 24; exchange of perspectives between 96-9

Humphrey, C. 106n5

Husserl, E. 106n4

hybrid personhood, in ritual transactions $84-5$ 
IL\&FS see Infrastructure Leasing and Financial Services (IL\&FS)

impurity 89

inām 141, 155, 156

Inden R.B., 93n 1

Indian National Congress 155-6

Indian Strategic Petroleum Reserves

Limited (ISPRL) 237

individualism 4

individual property $170-2$

individual rights, pursuit of $180,198-9$, 204-6, 255

industrial plant, umwelt in 28,210 , 236-47, 250, 256, 257; adikāra in industry, undertaking 243-4; explosion on path of būta 237-8; intimacy with land and deities in MSEZ 238-40; malfunction of machine and ritual, organised by Japanese engineers 241; pipeline connection with a banyan tree 241-3; threatening industrial plant 240-3; towards new umwelt 245-6

Infrastructure Leasing and Financial Services (IL\&FS) 231n1

Ingold, T. 32n 29

inheritance: from father to son 192-4; of 'grandfather's land' 191-2; of traditional family land 191-2

Ishii, M. 30n7, 30n9, 31n27, 93n12, 102, 106n14, 133n6, 246n1, 247n4, 247n5

ISPRL see Indian Strategic Petroleum Reserves Limited (ISPRL)

Jackson, M. $31 \mathrm{n} 28$

Jain $67-8,137,138,140,147,161 \mathrm{n} 6$

caste (jāti) 37, 38, 44, 52-3, 53, 58n7, 89, $117,152, \mathbf{1 5 2}, 153, \mathbf{1 5 3}, 183,187, \mathbf{1 8 7}$, 188, 188, 189

Jayānanda-Pilicāmuṇụi 76-8, 124, 127

Jensen, C.B. 7, 30n 10

jōga 21, 22, 31n26, 31n27, 94, 101-5, $113,132,234,246,251-3,257-61$

Johnson, P.C. 4, 106n3

Jumādi's agency: officers in 219; violent land acquisition and 217-18

kabarụ (kavalu) 160, 168, 170, 171, $173,175,176,177, \mathbf{1 7 8}, 179,180$, $181 \mathrm{n} 9,181 \mathrm{n} 12,182 \mathrm{n} 17,190,191,192$, 198-200, 205, 255; land tenure of 174 kambula ritual 42, 43-4, 47n17, 47n21, $47 \mathrm{n} 22,85-7,252$

Kanaka Bottu Janana 62
Kanara Chamber of Commerce and Industry (KCCI) 234n 1

kañciụl bali 70

Kandettāya 64-5, 69n8, 76

kānike 142

Kapferer, B. 95, 106n2

Karnataka Industrial Areas Development Board (KIADB) 213, $234 n 1$

Karnataka Land Reforms (Amendment) Act, 1973 (Karnataka Act No. 1 of 1974) 155, 157-60, 163n31, 179, 180, 183, 188; būtas' curse over transfer of land rights, fear of 202-4; duties to the kuṭma and pursuit of individual rights 204-6; lost land due to land reform 195-7, 195; tenants and land reforms 200-2; village landlords, application for land rights by 197-200

Karp, I. $31 \mathrm{n} 28$

katțu (customary law) 23, 52, 57, 79, 80, $109,118,121,123,124,127,131,132$, 199, 244, 254

KCCI see Kanara Chamber of Commerce and Industry (KCCI)

Keladi Nāyaka period, land system in 141-3, 161n3

Kelinga's Janana 62

Keller, M. 95, 98

kesarụkallụ pāḍuni 239

KIADB see Karnataka Industrial Areas Development Board (KIADB)

Kimura, B. 14, 18, 31n23, 31n27

Kimura, S. 247n6

Kinni Majalu Ishta Devata Balavandi Pilichamundi Daivastanam 116

Kohn, E. 30n10, 32n29, 106n5

kōla (būta rituals) 139

Koratāi Balardi 45, 64, 65, 67, 68, 140

Krishi Bhumi Sanrakshan Samiti 213, 214, 234n2

Kuḍubi 39

kumerụ 41, 41

kuțuma (kuțumba) 27, 38, 55, 68, 90, 93n10, 129, 139, 148, 152, 154, 159-60, 162n18, 165, 169, 172, 183, 190-9, 202, 207n8, 207n11, 209, 250, 254-5; duties to 204-6; land tenure of 174; in Madras Aliyasantana Act of 1949 168; partition by kavalu 170; partition plan for 174-9, 177-8; property of 170 ; under the enactment and amendment of modern law 173-4, 179-80 
Laidlaw, J. 32n28, 93n8

Lambek, M. 31n 28

Land Acquisition Act, 1894 235n 7

land acquisitions: conflict between guttu families and politics of 220-4; violent, and Jumādi's agency 217-18

landholder 27, 40, 136, 137, 143, 144, 147-50, 153, 159, 161n1, 161n5, 162n16, 193, 198, 203, 206n2, 214

landlord as broker, for development project 223-4

landlord family, immigration of 226-8

landlord households: group composition of 188, 188, 189; land holdings and acquisitions by 189-91, 190

land reform: 1947-1956 155-6; 1956-1971 156-7; 1971-1977 157-60; after independence 155-61; lost land due to 195-7, 195; as 'owners of land' $183-208$; in village society $185-6$,

185,186

land rights: transfer of, fear of the būtas' curse over 202-4; by village landlords, application for 197-200

land tenure 1, 23, 24, 25, 27, 45, 133, 164, 183, 191, 205, 206, 209, 226, 232, 253, 256; in Âlupa period 137; in colonial South Kanara 141-9; in early twentieth-century Perar 149-55; historical changes in South Kanara 135-63; of kabaru 174; in Keḷadi Nāyaka period 141-2; of kuțuma 174; land characteristics and tax policy 148-9; Munro's intentions and 'invention of tradition' $145-8$; in pre-colonial South Kanara 136-41; ryotwari system $142-5,147-8$, 160 ; transformation of $160-1$; in Vijayanagara period 137-8

land tribunal 158, 185, 186, 198-200, 205, 206, 254

Latour, B. 30n11

Leach, J. 30n9

Lienhardt, G. 106n10

Luig, U. 30n7

Lukes, S. $31 \mathrm{n} 28$

Maclean, C.D. 162n17, 162n22, 206n1

Maḍdyele 40

Madhava, K.G.V. 141, 161n6, 161n11

Madras Aliyasantana Act, 1949 (Act No. 9 of 1949) 27, 165, 166, 168-70, 174, 175, 180, 181n7, 209; kuțumba in 168
Madras Aliyasantana (Mysore Amendment) Act, 1961 (Act No. 1 of 1962) $165,170,181 \mathrm{n} 7,207 \mathrm{n} 11$

Madras Endowments and Escheats Regulation, 1817 (Regulation VII of 1817) 115

Madras government 144-6, 148

Madras Hindu Religious and Charitable Endowments Act 1951, 133n13, 221

Madras Hindu Religious Endowments Act (Madras Act II of 1927, HRE Act) $24,115,116,118,133 \mathrm{n} 9$

Madras Legislative Council 115

Madras Presidency 150, 162n13, 165

Madurāya Pejattāya 63

māgaṇe 139

magic: in non-Western societies 2

majalụ 41

malfunction of machine and ritual, organised by Japanese engineers 241

Mangalore Circle Temple Committee 116

Mangalore Refinery and Petrochemicals Limited (MRPL) 211, 235n5, 240, 241

Mangalore Special Economic Zone (MSEZ) 210-12, 225-9, 232, 233, 234n1, 236, 237, 242-6; antidevelopment movement, led by local magnate and village deity 213-14; būta worship, as stronghold of resistance 211-12; deity, as the supreme commander 218-19; intimacy with land and deities in, rediscovering 238-40; local movements against 213-16; officers in ritual and Jumādi's agency 219; protest against company and landlords by small farmers 214-16; violent land acquisition and Jumādi's agency 217-18

Mangalore Special Economic Zone Limited (MSEZL) 210, 211, 234n1, 235n 5,236

Mangaluru 2, 29n3

Mañgaḷūru rājya 137

market economy 4

Marriott, M. 23, 82-4, 92-3n1 marumakkattāyam 168, 181n5

Masquelier, A. 5, 30n7

material possession 4

matriliny $24,25,27,67,136,154,155$, $161,164,165,168,171,172,181 \mathrm{n} 5$, $183,194,206,253-5,256$

Mawri: modernity and occult 4-5 māya $21,22,3 \ln 26,68,94,101-3,105$, $132,243,246,251-3,257-61$ 
māyi 1

Mead, G.H. 95, 106n4

Menon, D.P. $181 n 6$

Merleau-Ponty, M. 31n24, 106n4

Meyer, B. 30n 8

mimesis 95, 96, 98; multiple 100-1, 103,253

mimetic art of būta mediums 99-101

mimetic faculty 95

Mines, M. 32n28

modernity 30n 7, 30n 15, 95, 106n2, $248-58,261$; theories of $2-5$; of witchcraft 3, 4, 9

Mol, A. 246n1

Mongolia: shamanism in 9

Moore, H.L. 30n7

Moore, M.A. $181 \mathrm{n} 6$

Moyli 39-40

MRPL see Mangalore Refinery and Petrochemicals Limited (MRPL)

MSEZ see Mangalore Special Economic Zone (MSEZ)

MSEZL see Mangalore Special

Economic Zone Limited (MSEZL)

muḍi gēni $175,176,181 \mathrm{n} 15$

Mudu Perar 1, 29n4, 35-47, 149, 183, 187, 189, 191-4, 207n3, 207n11, 208n12, 235n9; būta shrine and deities in 1, 48-59; domestic labourers in 184; land, forests, and deities 39-46, 41, 42; landlords and land reforms in 195-7, 195; land tenure and pațtadār/paț̣adārti, in early twentieth-century $150-5$, 151-4; social composition of 37-41, 37, 38; tenants and land reforms in $200-2$; tenants in 184 ; village shrine in $48-50$

muga pattuni (muga dīpuni), 77

mukkāldi 39, 48, 51, 55-6, 67, 68, 70-2, $74,75,81 \mathrm{n} 2,101,102,106 \mathrm{n} 13,122$, 127,139

Mukkāldi-Balavāṇ̣̣i 71, 75-80, 81n4, $122-4,127$

mūla gēṇi 162n26, 179, 184, 199, 200, 206n1, 206n2, 207n3, 207n8

mūliga 137

multinaturalism 5

Mundạabețtu guttu 27, 29, 36, 43, 44, $47 \mathrm{n} 17,47 \mathrm{n} 24,52-5,58,60,64,66$, $68,69 \mathrm{n} 5,115,119,121-3,125-8$, 132, 134n14, 149, 150, 153, 154, 161, $162 \mathrm{n} 18,172-6,181 \mathrm{n} 15,182 \mathrm{n} 16$, 185, 186, 188, 191, 194, 198, 199,
201-5, 223, 259; astrological ritual and 129, 130; Brahman priest, hiring of 115; coping with modern law 179-80; divide inheritance of land in 161; enactment and amendment of modern law 173-4; families and deities, pāḍdana on 67, 121; family property partition plan $\mathbf{1 7 7 - 8}$; lands applied for rights in 186; and shrine development 125

Munda Chetty v. Thimmaju Hengsu (1863) 166

Munn, N.D. 93n5

Munro, T. 142-50, 162n13

Muttaya Shetty 175, 176, 179, 180, $182 \mathrm{n} 17$

Muzarai Department 222

Mysore (Personal and Miscellaneous) Inams Abolition Act 156

Mysore (Religious and Charitable) Inams Abolition Act 156

Mysore Alienated Villages (Protection of Tenants and Miscellaneous Provisions) Act 156

Mysore Land Reforms Act, 1961 (Mysore Act No. 10 of 1962) 155-9, $163 n 30$

Mysore Land Reforms Bill 156

Mysore Tenancy and Agricultural Land Laws Committee 156

Nādu 139; battle with Brammabermerụ $61-2,76$; birth of 60 ; travels with king 61

Nāga 45-6

nāgarapańcami 45-6

Nalike 140,56

National Planning Commission 157

Nellidādi guttu 216-24, 232, 233, 238, 243

nēma 26, 36, 48-51, 53, 55, 57, 59n11, 59n13, 60, 62, 65-8, 72-4, 76, 78-80, 81n1, 82, 86-92, 103, 104, 106n3, 119, $125,126,131,135,139,218,219,222$, 259; conflict in, and judgement of the deity 122-4; day before 70-1

nēma decci (second-half ritual to Arasu) 73-4

neoliberalism 5, 248

New Mangalore Port Trust (NMPT) $234 n 1$

Niger 5

NMPT see New Mangalore Port Trust (NMPT) 
OBC see Other Backward Classes (OBC)

occult: economies 3-5; modernity and 2-5

Oil and Natural Gas Corporation Ltd (ONGCL) 234n1

ONGCL see Oil and Natural Gas

Corporation Ltd (ONGCL)

Ontisches 18-20, 251, 258

ontological anthropology 248-52

ontological questions 5-7

ontological reality of the other 5-10

ontological self-determination 5-8, 14 , $15,249,250$

ontological turn (OT) 6-10, 30n11, $30 \mathrm{n} 12$, 250; being/existence 10-15; critiques of 7-8

ontology: Amerindian 13-14; traditional use of the term 13

Osella, C. $32 \mathrm{n} 28$

Osella, F. 32n 28

OT see ontological turn (OT)

Ota, N. 143, 148

Other Backward Classes (OBC) 37, $46 n 7,234 n 3$

pāḍdana (oral mythological epics) 23, 26, 36, 56-8, 60-9, 69n1, 73, 75, 76, 79, 100, 104, 121, 135, 140, 244; of Arasu $62-5$; on guttu families and deities 67-8; of Nadu 60-2; of Pilicāmuṇ̣̣i 65-6

padiari pattuni 70

Padu Perar 29n4, 35-47; būta shrine and deities in 1, 48-59; domestic labourers in 184; Kinni Majalu Ishta Devata Balavandi Pilichamundi Daivastanam 116; land, forests, and deities 39-46, 41, 42; Shastavu Brahma Balavandi Pilichamundi Daivastanam 116; social composition of $37-41,37, \mathbf{3 8}$; tenants in 184; village shrine in 48-50

Pambada 1, 40; dancer-mediums 56-8 pañcāmṛta abhișēka 46

Pani, N. 158, 159

panikụ kulluni 47n22

Panjuūrli būta 139

Parry, J. 32n28, 93n2, 93n3, 133n4, 246n1

partition plan, for kuțuma land 174-9, 177-8

Pathisches 18-19, 20, 251, 258

pathos 18, 251-2, 259, 261

patțadār 136, 145, 148, 159, 161n1, 161n5, 162n18, 162n27, 173, 176, 182n17; caste/type of $\mathbf{1 5 2}$; land holding and land tax assessment of 149-55, 151-4

Pedersen, M.A. 9, 30n15, 106n1, 106n5

Pējāvara Mutt 152, 162n26, 179, 186, 198, 199, 207n8, 227-9

Pels, P. 30n 7

people's intentions, complication of 124-31; būta dancer, dilemma of 126-7; democratisation expectation and shrine development 125-6; guttu family from the shrine, withdrawal of 126-7

Perar see Mudu Perar; Padu Perar

Perara Sanskriti Protishtāna (Perar Cultural Committee) 131

Perar Shastavu Brahma Bhoota 116

pergade: under the enactment and amendment of modern law 173-4 permeability 94-6

permeable person $95-6$

perspective $24,26,88,252,253$; mimetic art of būta mediums 99-101; playing with 94-106; ritual transaction and transformation of the self 103-5; spirit possession and permeable person 95-6

perspective exchange, between humans and nonhumans 96-9

perspectivism 26; Amerindian $13,96-7$

personhood 4, 18, 23, 31-2n28, 82, 93n1, 96; dividual 82-4; hybrid, in transactions 84-5

Piaget, J. 106n4

Pilicāmuṇdị 51, 65-6, 89, 123, 127; ritual for 76-7

Pinney, C. $133 n 6$

pipeline connection with a banyan tree 241-3

Pocock, D.F. 93n9

Poduvāl 134n14

pollution 88-90, 93n10, 93n11, 211

possession 55, 77, 110, 259; material 4; spirit 3, 4, 23, 95-6

possibility 14

prakriti 29n2

prasāda 1, 29-30n6

Presler, F.A. 133n1, 133n13

Pūjāri 37, 39, 43, 52, 55, 64, 73, 75, 78, $128,189,193,197-9,201-3$

pūkare 43, 47n19

purity $88-91$

Puruṣa 40; musicians 1 
radical constructivist approach 12

radical essentialism $5,7,14,250$

Raheja, G.G. 32n28, 93n2

Rajapurohit, B.B. $181 \mathrm{n} 8$

rājya 139

Ramesh, K.V. 136-9, 146, 147

Ranger, T. 30n9

Rao, B.S., 142

Rao, G.K. 167

rasa $103-4$

Rashtriya Swayamsevak Sangh (RSS) $235 \mathrm{n} 4$

rationality $4,9,30 \mathrm{n} 13,125$; modern 4,6 , 8, 9-11, 30n $13,125,249,250$

Read, A. 143, 149-50

reality 14

'realm of the wild, the' 1, 20, 21, 29n5, 91, 92, 122, 135, 204-6, 218, 232-4,

$236,244-6,248,252,255-8,260,261$

registration records of land rights application 185-6, 185, 186

Religious Endowments Act of 1863 (Act XX of 1863) 115

religious institutions in South India, modern administration of 110-12

religious leader fasting against development project 228-30

Revenue Board 149, 150, 173, 176

Revenue Settlement Office, Mangalore 151

Right to Fair Compensation and Transparency in Land Acquisition, Rehabilitation and Resettlement Act, $2013235 n 7$

ritual community 81, 88, 165, 169, 172, 244

ritual murder 3

ritual pollution, wild śakti and 88-92

ritual transaction, and transformation of the self $103-5$

ritual transactions between deities and people 78-81; circulation of śakti 85-8; divided persons 85-8; dividuality $82-4$; hybrid personhood 84-5

rivalries over deities 224-30

Rosenthal, J. 95

RSS see Rashtriya Swayamsevak Sangh (RSS)

rūpa 103

ryotwari system $142-5,147-8,160$, $162 \mathrm{n} 17$

sacred wildness $1,21,252,258$

sacrifice 78, 93n6, 166

Sakabe, M. 106n4, 106n14 śakti (divine power) 1-2, 20-2, 29n2; circulation of 85-8; and kambula ritual 43-4, 85-6; and ritual pollution 88-92; transaction of 82-93; untamed 90-2

Samajwadi Party (SP) 215, 234n3

samudāya 137

Sanders, T. 3-4, 30n7

Sangh Parivar 235n 4

Sanskritisation 47n13, 52, 58n7, 89

Santo, D.E. 106n8

Śāstāvu Bramma 128

Satanism 3

Sausdal, D.B. 7, 8, 13, 30n10

Save the Cultivated Land Committee 213

Sax, W.S. 32n28, 93n1

Scheduled Castes (SC) 37, 46n4, 234n3

Scheduled Tribes (ST) 37, 46n4, 234n3

Schütz, A. 106n4

Sekine, Y. 91, 93n9

self-reflexivity 98, 103

sețtikāra 138

Sēvā Samiti 119

shamanism 23, 96, 97; Darhad 9; in Mongolia 9

Shastavu Brahma Balavandi Pilichamundi Daivastanam 116

Shiva, V. 32n 32

shivering deity 130-1

shrine development, democratisation expectation and 125-6

shrine reconstruction 127-8

Siberian Yukaghirs 98

sīme 139

Singh, K.S. 47n14

small farmers, protest against company and landlords by $214-16$

Smith, F.M. 4, 96

social body $103-5$

Sontheimer, G.D. 133n3

South Africa: occult economy 3

South Kanara District Temple Committee 116

SP see Samajwadi Party (SP)

spirit possession 2, 4, 21, 23, 28, 30n7, $31 \mathrm{n} 26,51,56,57,94-6,102,105$, 106n2, 115, 122, 225, 248, 251, 259, 260; in non-Western societies 3

Sri Lanka, demonic possession in 95

Srinivas, M.N. 58n7

Śrī Pārtasārati Svāmi temple 111

SSRM see Survey and Settlement Register, Mudu Perar Village, No. 53 (SSRM)

ST see Scheduled Tribes (ST) 
Stambach, A. 30n13

Stein, B. 143, 145-8, 162n21

Stoller, P. 95

Strathern, A. $31 \mathrm{n} 28$

Strathern, M. 24, 26, 30n11, 84-5, 87, $93 n 4$

Sturrock, J. 142, 146, 149, 162n17, 165, 206n1

subject 16-18

substance-code 24, 26, 83-8, 92-3n1, 93n5, 93n8, 101, 105, 169

śudda malpuni 93 n10

Sultan, Tipu 136, 142, 161n6

suriya pādonuni $81 \mathrm{n} 7$

Survey and Settlement Register, Mudu Perar Village, No. 53 (SSRM) 150-4, $162 \mathrm{n} 27$

Swain, A. 32n 32

Swancutt, K. 106n5, 106n8

Tambiah, S.J. 30n13

Tanabe, A. 32n31, 161n9

Tanaka, M. 90, 93n9, 93n11

Taussig, M. 2-3, 95

tax policy $148-9$

Taylor, A.C. $106 \mathrm{n} 7$

tenant households, group composition of $\mathbf{1 8 8}, 189$

Thimmaiah, G. 155, 156, 163n31

Thurston, E. 32n33, 46n8, 46n9, 47n10, 47n11, 47n13-15, 134n14

Tio: Bolivian miners' worship of 2

Togo, Gorovodu possession in 95

traditional family land, inheritance of 191-2

traditional rights, crisis of $118-22$

transactional networks $24-6,28,44$, $79,82,83,85-8,93 \mathrm{n} 8,94,105$, $111-15,124,132,165,169,172,206$, 236-7, 240, 241, 243-5, 252, 254, 255, 257,258

transformation of the self, ritual transaction and 103-5

trusteeship of village būta shrine in 1930s, disputes over 115-18

tudara bali 71

Tulu 21

Tumbe Jāla Janana 62

Turner, T. 97

Uchiyamada, Y. 93n5

Učida, N. 181 n8

umbali 141

umwelt 70, 82, 94, 105, 109, 234, 248, 251-2, 256, 257, 260, 261; anthropology of 1-32; in industrial plant 236-47; for the people 21-2

untamed śakti 90-2

Upadhyaya, U.P. 31n26, 32n30, 47n17, $47 \mathrm{n} 19,47 \mathrm{n} 22,58 \mathrm{n} 5,58 \mathrm{n} 6,133 \mathrm{n} 5$

ūru 139

uttāra 141

vākụ piripuni 48, 51, 66, 70, 76-8, 81n9, 122,123

VHP see Vishwa Hindu Parishad (VHP)

Vigh, H.E. 7, 8, 13, 30n10

Vijayanagara period: administrative system and būta rituals in 138-41; land tenure in 137-8

Vilaça, A. 106n7

village deity, regaining $230-4$

village landlords, application for land rights by $197-200$

village shrine, in Perar 48-50

village society, land reforms in 185-6, 185,186

Villagewar Resister of Applications Filed under Section 48-A before the Tribunal (VRA) 185, 198

virtuality $12-15,31 \mathrm{n} 27,253,258$

Vishwa Hindu Parishad (VHP) 228, $235 \mathrm{n} 4$

Viveash, H. 150

Viveiros de Castro, E. 6-8, 13-14, 24, 30n11, 30n14, 30n16, 96-7, 106n1, 106n6

von Uexküll, J. 15-16, 251

von Weizsäcker, V. 15-20, 31n20, 31n25, 98, 251

VRA see Villagewar Resister of Applications Filed under Section 48-A before the Tribunal (VRA)

Wadley, S. 93n9

Wastell, S. 12, 30n11

West Africa, Hauka possession in 95

wild būtas, worship of 225-6, 253-8

Willerslev, R. 24, 32n29, 98, 106n1, 106n6

Wilson, B.R. 30n13

Winthereik, B.R. 7, 30n10

witchcraft, modernity of 3, 4, 9

yajamāna/yajamāni 167, 169, 181n3

Yatish-Balavāṇụi 74-6

zamindar $143,162 \mathrm{n} 14$

zamindari 144, 145, 148, 156, 162n14

zombies 3 


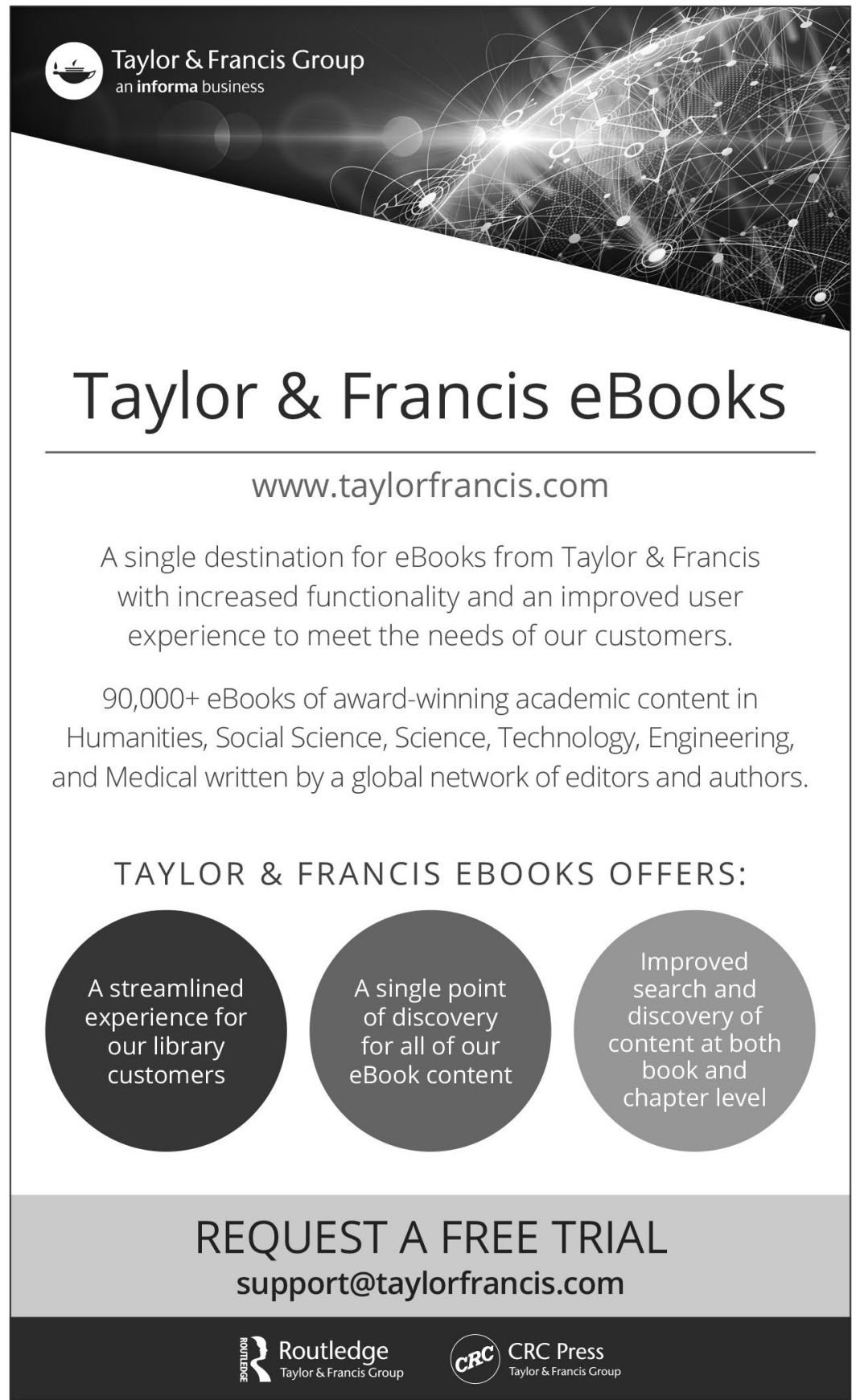

